\title{
The Tree Trunk Can Be My Pillow
}

The Biography of an Outstanding Japanese Canadian

\section{TADASHI JACK KAGETSU}

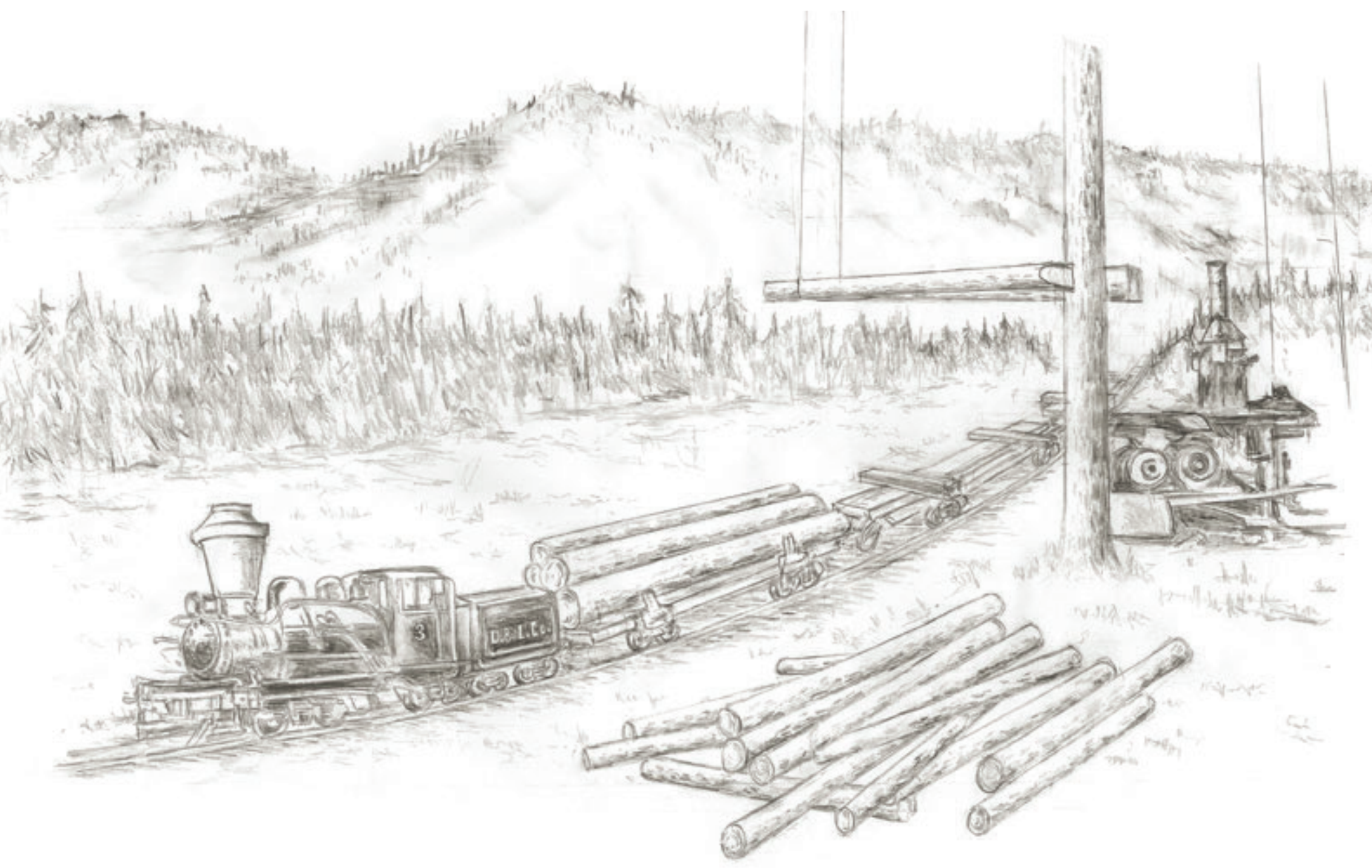



The Tree Trunk Can Be My Pillow 



\section{The Tree Trunk Can Be My Pillow}

\section{The Biography of an Outstanding}

Japanese Canadian

\section{TADASHI JACK KAGETSU}

Introduction by Dr. Jordan Stanger-Ross 
Copyright $\odot 2017$ by Estate of Tadashi Jack Kagetsu

Published in Canada by University of Victoria

Victoria, $\mathrm{BC}$ V8P $5 \mathrm{C}_{2}$

press@uvic.ca

Cover image: Sketch of train at Deep Bay Logging, Fanny Bay by Kaz Tsuchida circa $1920 s$.

Book design by Rayola Creative

Printed and bound by University of Victoria Printing Services on

$100 \%$ post-consumer content recycled paper.

This book is released under a Creative Commons Attribution 4.o International (CC BY-NC 4.0) license. This means that you are free to copy, redistribute or adapt this book for non-commercial purposes. Under this license, anyone who redistributes or modifies this book, in whole or in part, can do so for free providing they properly attribute the book as follows:

Kagetsu, T. J. (2017). The tree trunk can be my pillow: The biography of an outstanding Japanese Canadian. Victoria, BC: University of Victoria.

Additionally, if you redistribute this book, in whole or in part, in either a print or digital format, then you must retain on at least one page at the front of a print copy the following attribution:

Kagetsu, T. J. (2017). The tree trunk can be my pillow: The biography of an outstanding Japanese Canadian. Victoria, BC: University of Victoria. This book is published by the University of Victoria under a CC BY-NC 4.o International license.

For questions about this book, please contact the Copyright and Scholarly Communication Office, University of Victoria Libraries at press@uvic.ca.

\section{Library and Archives Canada Cataloguing in Publication}

Kagetsu, Tadashi Jack, 1931-2006, author

The tree trunk can be my pillow : the biography of an outstanding Japanese Canadian / Tadashi Jack Kagetsu.

Includes bibliographical references.

Issued in print and electronic formats.

ISBN 978-1-55058-611-4 (softcover).--ISBN 978-1-55058-612-1 (PDF).--

ISBN 978-1-55058-613-8 (EPUB)

1. Kagetsu, Eikichi. 2. Japanese Canadians--Biography. 3. Businesspeople--British Columbia--Biography. 4. British Columbia--Biography. 5. Biographies. I. Title.

FC106.J3 $\mathrm{K}_{3} 62017 \quad 971.1^{\prime} 0049560092 \quad$ C2017-903950-4

C2017-903951-2 


\section{Contents}

\begin{tabular}{|c|c|c|}
\hline & Introduction & $\mathbf{i}$ \\
\hline CHAPTER 1 & Hard Life of a First Born & 1 \\
\hline CHAPTER 2 & Getting Started in a New Land & 9 \\
\hline CHAPTER 3 & Early Logging Ventures & 13 \\
\hline CHAPTER 4 & A Large-scale Logging Operation & 27 \\
\hline CHAPTER 5 & Life in a Logging Camp & 39 \\
\hline CHAPTER 6 & An Unwanted Partnership & 49 \\
\hline CHAPTER 7 & Personal Life & 57 \\
\hline CHAPTER 8 & Maintaining Japanese Traditions & 73 \\
\hline CHAPTER 9 & Education Is a Top Priority & 83 \\
\hline CHAPTER 10 & A Man of Faith in Action & 95 \\
\hline CHAPTER 11 & The Canadian Japanese Association in Action & 105 \\
\hline CHAPTER 12 & Other Activities in the Community & 111 \\
\hline CHAPTER 13 & Participation in Memorable Events & 119 \\
\hline CHAPTER 14 & The Vimy Pilgrimage and Berlin Olympics & 133 \\
\hline CHAPTER 15 & A Great Honour is Savoured & 145 \\
\hline CHAPTER 16 & Pearl Harbor and Its Aftermath & 155 \\
\hline CHAPTER 17 & Our Lives are Changed Forever & 169 \\
\hline CHAPTER 18 & Meagre Compensation for Liquidated Assets & 177 \\
\hline CHAPTER 19 & Starting a New Life in the East & 187 \\
\hline CHAPTER 20 & The Elder Statesman is Still Active & 197 \\
\hline CHAPTER 21 & Life's Sunset & 209 \\
\hline BIBLIOGRAPHY & & 215 \\
\hline APPENDIX I & List of Fanny Bay Residents (1942) & 231 \\
\hline APPENDIX II & Canadian Japanese Association & 233 \\
\hline APPENDIX III & Speech by Eikichi Kagetsu, Representative from Canada & 235 \\
\hline APPENDIX IV & Security Report on Eikichi Kagetsu & 241 \\
\hline APPENDIX V & MacInnis Speech on Eikichi Kagetsu Case & 244 \\
\hline APPENDIX VI & Eikichi Kagetsu Descendancy Chart & 250 \\
\hline
\end{tabular}




\section{ACKNOWLEDGEMENTS}

On behalf of the Kagetsu family, we extend sincere heartfelt gratitude for the contribution of numerous individuals and organizations to Tadashi Jack Kagetsu's original manuscript. Translation of Eikichi Kagetsu's Japanese language documents into English was completed by Takako Kagetsu Huang and Bill Hashizume. Further acknowledgements include but are not limited to: Ann Carroll, Claudia Cole, Janette Glover-Geidt, Tsuneharu Gonnami, Rick James, Barb Lemky, Bob Muckle, Arv Olson, Red Robinson, Fred Rogers, Catherine Siba, Barbara Simkins, Ann Watson, and Tony Wilson. Thanks also to Alisa Lazear, Library Intern, School of Library, Archival and Information Studies, UBC, who meticulously checked the bibliography.

Special thanks to Dr. Jordan Stanger-Ross for his introduction to this book, to Nikkei National Museum staff Sherri Kajiwara, Linda Kawamoto Reid, Lisa Uyeda, Carolyn Nakagawa, Erica Isomura, and researchers Trevor Wideman, Eiji Okawa, Jessica Gerlach, Audrey MacDonald, Lane McGarrity, Kaitlin Findlay and Nathan Yeo.

We acknowledge the financial assistance of the Tadashi Jack Kagetsu family, the Nikkei National Museum \& Cultural Centre, and the Landscapes of Injustice (www.landscapesofinjustice.com) and Asian Canadians on Vancouver Island (http://vi-asiancanadians.ca) research projects. 


\title{
Introduction
}

\author{
By Dr. Jordan Stanger-Ross \\ Department of History, University of Victoria
}

1 This introduction benefited from the reading and comments of the wonderful students whose research assistance also contributed to its production, including: Kaitlin Findlay, Trevor Wideman, and Nicole Yakashiro. Thanks also to Sherri Kajiwara for inviting this contribution and to the Kagetsu family for their encouragement of this volume as a whole and their openness to a scholarly introduction.

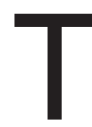

his book is a son's tribute to his father, delivered to readers after the death of both. As Jack Kagetsu laboured for a decade on his manuscript, travelling to archives, combing newspaper articles, and organizing his findings as well as his memories into writing, he must have felt that he was discovering parts of himself as well as his father. It is a very personal history. The book also has communal resonance for Japanese Canadians. It reflects reverence for elders and speaks to the accomplishments and losses of a generation of immigrant founders, the Issei. In the case of Eikichi Kagetsu both accomplishment and loss were of staggering proportions; perhaps no one else built so much, only to see it stolen in the mid-twentieth century odyssey of Japanese Canadians.

Pull back further and we read a Canadian history. Kagetsu was an immigrant entrepreneur in a province and a country awash with the same. He was a Canadian delegate at the unveiling of the Vimy Ridge War Memorial in 1936, making time during that visit to pay respects at the gravesites of members of his community who fell during the Great War and to take an afternoon tea at Buckingham Palace. His story is Canadian, too, in his uprooting, internment, and dispossession in the 1940s - major episodes in the history of the country. Published now, 75 years after the internment began, and in the midst of a renewed international reckoning with the intermingled histories of migration, race, and national security, this very intimate story also speaks to topics of global significance.

Kagetsu arrived in British Columbia in June of 1906, at the age of 23. He rode a wave of mass migration. More than 11,000 Japanese came to British Columbia between 1906 and 1908, joining a booming province whose popu- 
lation doubled during the decade, mostly due to immigrants. ${ }^{2}$ Like so many, Kagetsu came to Canada because of the stories of returnees. The oldest of nine living children in a poor household in Wakayama Prefecture-a decorated veteran of the Russo-Japanese War, and from a very young age, an entrepreneurKagetsu heard tales of Canada. Rumour of British Columbia's "forests with their giant trees" (chap. 2, p. 9) prompted his belief that he might make his fortune in the logging industry, with which, through an uncle, he had some familiarity. ${ }^{3}$ This hunch turned out to be astonishingly correct.

Kagetsu arrived in British Columbia with \$39 dollars, 14 more than the minimum requirement for a Japanese arrival at the time. Beginning as a labourer in mines and sawmills, he saved and planned, managing to acquire rights to 160 acres in 1908, which he supplemented with the purchase of an additional 640 two years later (chap. 3, p. 15-16). Despite his rapid jump from worker to owner-a rise in status that the biography does not entirely explain-the story of these years, and indeed of Kagetsu's three decades in Canada prior to the Second World War, is not one of simple ascent, but rather of the struggle and uncertainty of success in British Columbia's logging industry. In 1912, an unexpected freezing of the Fraser River brought disaster: losses of some $\$ 10,000$ worth of product and bankruptcy (chap. 3, p. 16). Kagetsu was once again a labourer and, for a time, a gardener in Vancouver. Then, in 1915, he rejoined the fray as a business owner and by the decade's close he employed dozens of men, producing some 20,00o board feet of timber every day, largely for export to Japan (chap. 3, p. 25-26). The 1920 s were a decade of prosperity and growth for the Kagetsu enterprise, but the next decade as for many others, brought renewed struggle. Dramatic fluctuations in demand and two devastating fires nearly bankrupted Kagetsu \& Company for a second time (chap. 3 \& 4). By 1941, he managed to rebuild his business, only to see the entire operation ripped from his control after the forcible uprooting of Japanese Canadians in the year that followed (chap. 4, p. 38 \& chap. 18). These chapters of the biography give life to the Japanese proverb that Toyo Nakamoto, Kagetsu's bride in 1910, used to describe her first years in Canada-nana korobi hachioki- “you fall seven times but for the eighth time ready for work again" (chap. 3, p. 17).

The details of this journey, and the struggle that Jack Kagetsu carefully conveys, enrich the larger history of which they are a part. Along with other Japanese Canadians, Eikichi followed in the footsteps of "pioneers" who discovered and built economic opportunity in the decades prior. The first known Japanese immigrant to Canada, Manzo Nagano, stayed ashore in New Westminster in 1877 when the ship on which he had arrived departed for Japan. ${ }^{4}$ Borrowing a boat with an Italian partner, Nagano was likely the first
2 Sumida, 1935, p. 28; Belshaw, 2009, p. 32. Although the overall population (and economy) was booming in this period, it also marked a period of demographic catastrophe for First Nations peoples (ibid, pp. 72-90).

3 On stories and migration, see Morawska, 1993, pp. 241-63.

4 Adachi, 1976, pp. 9-13; On Japanese migration to Canada in this era, see Takai, 2011, pp. 7-34; Geiger, 2011. 
5 Sumida, p. 23

6 Dominion policy in favour of influx, Vancouver Daily Province, July 25, 1907, p. 1.

7 Adachi, 1976, pp. 63-87; Roy, 1989, pp. 185-228; Gilmour, 2004; Atkinson, 2015, pp. 120-140.

8 Adachi, 1976, pp. 142-153.

9 Sumida, pp. 102-3, 419; Switzer, 2012; Fukawa \& Fukawa, 2009; Ayukawa 2008; Takata, 1983; Adachi, 1976.

10 There is a voluminous scholarly literature on these topics. Readers might start with Roy, 2007; Sunahara, 1981; and Ward, 1978.
Japanese fisher in the Fraser River, and hence the forerunner of thousands in the half-century that followed. ${ }^{5}$ By the mid 1880 s, a steady flow of migrants from Japan arrived annually to Canada's west coast, where they found employment in the fishing, mining, forestry, and construction industries, in particular.

The surge in Japanese immigration in the first decade of the twentieth century spurred racist response. British Columbia journalists dispatched to ports of arrival warned readers that steamers "literally swarmed with the little brown men" who represented "the advance guard of a host soon to locate British Columbia." In September of 1907, a demonstration of the Asiatic Exclusion League in Vancouver spiraled into rioting, with exclusionists ransacking Chinese-Canadian and Japanese-Canadian businesses and homes in the east end of the city, causing thousands of dollars of damage, and sparking international controversy. ${ }^{7}$ Later the same year, the Japanese and Canadian governments signed an agreement that dramatically curtailed immigration from Japan, permitting only few exceptions, including the wives and sons of Japanese already in the country. As a result, a settlement of male sojourners became a Canadian community. Men like Kagetsu were joined by their wives and started families. In the decades that followed, Japanese Canadians diversified their lives and economic activities, transforming Fraser Valley districts long regarded as inarable into thriving berry farms, creating a hub of commercial and communal life in Vancouver's Powell Street neighbourhood, founding newspapers, schools, and communal associations, and finding other niches in the economy and society of British Columbia. ${ }^{8}$ By the 193os, in addition to working and (in rare cases) owning lumber operations, Japanese Canadians farmed the Okanagan, fished the West Coast of Vancouver Island and the Northern stretches of the mainland coast, laboured in mines, cooked meals, ran groceries, gardened, shaved beards, and operated small businesses in locales throughout coastal British Columbia. ${ }^{9}$

Although the biography emphasizes the opportunity of the first decades of the twentieth century-particularly in the form of "gigantic trees estimated to be 800 years old ... 15 to 16 feet in diameter and 200 feet high" (chap. 3, p. 13)it also returns repeatedly to the persistent racism that constrained JapaneseCanadian lives and livelihoods. Inequality-in housing and labour markets, schooling, political participation, and the application of law-made race a fault line of British Columbian society. ${ }^{10}$ The biography conveys its tremors in gentle but powerful ways. A labourer at the Britannia mines, Kagetsu spent some of his first months in Canada living in racially segregated housing. If indeed, as the biography suggests, "Caucasian and Japanese workers got along very well with no discrimination," there was nonetheless a "dramatic reduction in the 
number of Japanese workers" (chap. 2, p. 12) after the anti-Asian furor of 1907. As Kagetsu's business was taking flight in the late 19-teens and early 1920s, the province erected legal obstacles to his success, including an export ban and a prohibition against people of the "Japanese race" working Crown lands (chap. 3 , p. 19). Even once his business was well established, Kagetsu had to comply with such indignities as a law that "prevented Japanese from operating steamdriven equipment” (chap. 4, p. 29).

The labour of success and the insecurity of prosperity, especially in the face of unjust discrimination, makes the losses of the internment era all the more poignant. ${ }^{11}$ As Jack Kagetsu details, everything that his father had built in the prewar era, including the relationships developed in the course of three decades of industry, was stolen away in one cruel decade. In its broad strokes, the mistreatment of Japanese Canadians in the 1940s is well known. Although, like Eikichi Kagetsu, the large majority (75\%) of Japanese Canadians were British subjects and over 60 percent, like his children, born in Canada, Orders-inCouncil (laws passed by federal cabinet under the authority of the War Measures Act) required that they carry special registration cards and obey curfews, face restricted mobility and communications, and live with the constant threat of arbitrary searches of their homes. ${ }^{12}$ After the government declared Canada's west coast a "protected area" in January 1942, the 21,460 Japanese Canadians residing there (over 90 percent of the Japanese origin population in Canada) were forcibly uprooted. The internment resulted in the separation of families, forced labour for some, and, for others, incarceration in prisoner of war camps in northern Ontario. Over 12,00o Japanese Canadians were sent by train to live in hastily constructed shacks and abandoned buildings in various parts of the British Columbia interior. Approximately 4,00o were sent to grueling labour on sugar beet farms in Alberta and Manitoba. Slightly over 1,00o who had sufficient funds established so-called self-supporting camps where they paid for the costs of their own internment. In a departure from the policies of the United States, Canada maintained the internment until 1949, when restrictions on Japanese Canadians were finally lifted. Before then, nearly 4,00o Japanese Canadians were involuntarily exiled to Japan; in constituting nearly 20 percent of the prewar coastal population, this group far exceeded the deportees from the United States. Finally, unlike any other jurisdiction, Canada undertook the forced sale of all property owned by people of Japanese origins in coastal British Columbia, including citizens, as a matter of federal policy. ${ }^{13}$

Kagetsu felt these traumas along with other Japanese Canadians. He first felt Canada's internment era as a threat to his company: in March of 1942, with an astonishing 2.5 million board feet of timber felled on his lands and ready for
11 The phrase "insecurity of prosperity" is borrowed from the title of Morawska's (1999) outstanding book. Adachi (1976) emphasizes the importance of property ownership in this context, which, in his view, served to "counteract the very marginal and precarious position [Japanese Canadians] held within the hostile prewar society," p. 319.

12 The War Measures Act, in force from 1939 to 1945 , empowered the federal Cabinet to pass laws as Orders-inCouncil, without the approval of the legislature. Similar powers were extended after the war as the federal government steered demobilization. The uprooting, internment, dispossession, and deportation of Japanese Canadians-along with dozens of other policies regulating their lives (and those of other Canadians) were enacted as Orders-in-Council. For a useful discussion of the War Measures Act and Japanese Canadian challenges to their treatment during the 1940s, see Izumi, 1999.

13 Adachi, 1976; Sunahara, 1981; Roy, 2007, see: Robinson, 2009. For a similar summary of these events see: Stanger-Ross, Pamela Sugiman, \& the Landscapes of Injustice Research Collective, 2015. 
14 See: Stanger-Ross and Blomley (2017), Adams and Stanger-Ross (2017).

15 Order-in-Council PC 1942-2483.

16 Order-in-Council PC 1943-469.

17 See, Sunahara, 1981, chap. 8; StangerRoss, (2016). removal, Kagetsu was denied permission to retain employees long enough to bring this mountain of logs to market. In early April, he was forbidden from travelling to his business properties on Vancouver Island to wrap up his affairs (chap. 16, p. 158-159). Then came the uprooting of his family. On May 28, after a month of preparation, they boarded an overnight train to Minto City, a former mining concern, where they would inhabit a "self-supporting" camp and attempt to rebuild their lives (chap. 17). The family preserved records that provide a rare glimpse into the emotional experience of the uprooting. For Kagetsu, the internment meant forced idleness and impotence: during this period he expressed having "too much time on my hands" in which "every day has no meaning" (chap. 17, p. 175-176). Trapped in a deserted town, wasting years in "the prime of his life," apprehending from afar the devaluation and forced sale of everything he had created in the decades prior, Kagetsu shared the internment with thousands of others, but must have felt it in his own particular way. ${ }^{14}$

Critical to Kagetsu's story was the forced sale of the property of Canadian citizens of Japanese descent. Here details beyond those available to Jack Kagetsu, culled from the voluminous and complex records of the Canadian state by the first large-scale research project on this topic, Landscapes of Injustice, can help to situate the story told here. When the government of Canada uprooted Japanese Canadians from the coast, it passed a law (Orderin-Council 2483 of March 27, 1942) promising to hold their property for "purpose of protecting the interest of the owner" and to "release such property [back to its owners] upon being satisfied that [their] interests... will not be prejudiced thereby." ${ }^{15}$ It was in this context that Kagetsu placed his property in protective custody and departed for Minto City. In January of 1943, however, the federal government reversed course. Acting on the basis of a new Orderin-Council (469), federal officials undertook the sale of everything that Japanese Canadians had been forced to leave behind. ${ }^{16}$ This action was not undertaken for the security of British Columbia. No one imagined that the farms, houses, logging operations, or warehouses of personal belongings owned by Japanese Canadians posed a security threat. Instead, the interests of other British Columbians in acquiring the property, a scheme to settle returning soldiers on their farms, the administrative difficulties of protecting the property of nearly 22,00o people, the mounting costs of the internment (which were to be defrayed by property sales), and the commitment of key British Columbia politicians to permanently exile Japanese Canadians from the province encouraged a change in federal policy. ${ }^{17}$ In the spring, officials began to solicit offers for hundreds of parcels of real estate and to organize auctions of personal belongings. Everything would be sold. 
The new federal policy cost Kagetsu his life's work. In the spring of 1942, he had left his assets in the custody of P. S. Ross \& Sons (an accounting firm working as an agent of the Custodian of Enemy Property), reassured that this arrangement was intended for his protection. ${ }^{18}$ In May, prior to his departure from coastal British Columbia, Kagetsu appointed Carl M. Stewart, a shareholder of the Deep Bay Logging Company, to act in his absence. ${ }^{19}$ With Kagetsu and his predominantly Japanese-Canadian workforce in work and internment camps far from Fanny Bay on Vancouver Island, business slowed to a standstill, and his logging operations, seen as an important part of wartime industry, became a focus of government concern. ${ }^{20}$ Federal records demonstrate that pressure mounted for him to sell, but Kagetsu remained unsatisfied with the offers received and insistent that his conditions be met. Stewart wrote to P.S. Ross \& Sons on November 25, 1942 regarding Kagetsu's refusal to accept a low offer: "I first would like to advise that, in my last communication from Kagetsu who owns $92 \%$ of the Company's stock, and who, as you know, is a British subject, thinks that he should receive $\$ 5.00$ per thousand for the timber and use of the equipment, whereas, the best offer we have, to date, is $\$ 2.75$, and as far as Kagetsu is concerned, he says there is no hurry."21 To Kagetsu's understanding, they could wait for an acceptable offer. The government decided otherwise.

Once officials obtained clear authority to sell Japanese-Canadian owned property, they moved quickly to dispose of Kagetsu's holdings. In March 1943, the Custodian of Enemy Property warned Stewart that unless he was able to finalize an offer in a week's time, the government would assume responsibility for advertising Kagetsu's properties. ${ }^{22}$ Ultimately, Stewart was unable to secure a buyer, leaving the fate of Kagetsu's assets in the sole hands of the government. Starting in April, advertisements for the Deep Bay Logging Company, its assets, as well as Kagetsu's other timber holdings were published by the Custodian. ${ }^{23}$

Soon after a call for tenders was issued, the H.R. MacMillan Export Company, with which Kagetsu had competed and done business before the war, submitted an offer. In 1943 and 1944 federal officials concluded sales of the property to MacMillan, helping to expand a business that would become one of the world's great forestry companies in the postwar period. Kagetsu was never fully informed and never consented. In December 1946, he wrote to the Custodian inquiring as to the status of his property. ${ }^{24}$ Little did he know, the government had disposed of it for a fraction of its value two years prior. As the biography documents, these losses, like those of other Japanese Canadians, would never be adequately compensated. In the postwar inquiry into JapaneseCanadian losses, Kagetsu presented a claim for $\$ 464,134.02$ in losses (approx-
18 Deep Bay Logging Company Limited. (1942, April 14). Memorandum. (RG3369, Vol. 73, Case file 1388). Library and Archives Canada, Ottawa, Canada. The details of Kagetsu's engagement with the Custodian were first collected and summarized by Nicole Yakashiro, whose work is the basis for the paragraphs that follow.

19 Kagetsu, E. (1942, May 22). Statement. (RG33-69, Vol. 73, Case file 1388).

Library and Archives Canada, Ottawa, Canada.

20 Rosenberry, D. D. (1942, Augus28). Correspondence to Deep Bay Logging Co. (RG33-69, Vol. 73, Case file 1388). Library and Archives Canada, Ottawa, Canada.

21 Stewart, C. M. (1942, November 25). Correspondence to P.S. Ross \& Sons. (RG33-69, Vol. 73, Case file 1388). Library and Archives Canada, Ottawa, Canada.

22 Custodian of Enemy Property. (1943, March 27). Correspondence to Carl M. Stewart. (RG33-69, Vol. 73, Case file 1388, [p. 571]). Library and Archives Canada, Ottawa, Canada.

23 Notice of Calls for Tenders for Timber Area, 1943, [p. 208]; Logging Company Assets for Sale, 1943, [p. 332].

24 Kagetsu, E. (1946, December 2). Correspondence to Custodian of Enemy Property. (RG33-69, Vol. 73, Case file 1388, [p. 588]). Library and Archives Canada, Ottawa, Canada. 
imately $\$ 6,500,000$ in 2017 ). After lengthy consideration by the commission, he was awarded little more than a tenth of this amount (chap. 18, p. 182). ${ }^{25}$

Like all other Japanese Canadians, Kagetsu worked to rebuild his life after his uprooting and internment. The biography conveys a man whose accomplishments were effaced by state injustice, but whose spirit remained unbroken. Arriving in Toronto in 1945 at the age of 62, he attempted, over the next decade, to start again, making forays into import and dry cleaning businesses with the limited capital that he retained. These enterprises were not successful. Kagetsu was 73 years of age when the last of his business ventures failed, and his only remaining asset was the house he inhabited on Mountview Avenue, Toronto. Yet, these chapters are also about what the internment era could not steal. Kagetsu remained, even in these final years, a recognized and cherished member of his community, the centre of a rich family life, and a man of ambition. He urged his children to their own remarkable successes and collected awards for his greenhouse-grown chrysanthemums before passing away peacefully at the age of 83 .

Readers will find in these pages many further complications. A pillar of Japanese-Canadian institutions and a generous philanthropist, Kagetsu's leadership within the community was not, as Jack notes, without controversy. As a leader of the Canadian Japanese Association in the 1920s and 1930s, Kagetsu sidelined leftists and distributed a pamphlet supporting the Japanese invasion of China, which Ken Adachi later described as "totally misguided." ${ }^{26}$ In addition, the family's story was not one of straightforward assimilation. Deeply rooted in Canada, the Kagetsus also maintained enduring and strong connections with Japan, as many migrant families do with "back home." The biography also leaves silences, perhaps especially in the relationship between Kagetsu and his wife, Toyo. Careful readers will find meaning in what is not said here, just as they do in the lines of the biography. Perhaps most revealing, among the things not quite, or only partially said, is the relationship between Jack and Eikichi himself.

Jack Kagetsu, like his father, was a man of considerable accomplishment. A top student and four-time chess champion at the University of Toronto, Jack was remembered throughout his life for his exhibition victories over grandmasters Alexander Kotov and Samuel Reshevsky. With a PhD. in Chemical Engineering, he spent a 30-year career with the US firm Union Carbide, receiving two patents for technical innovation (in the memoir, however, he recalls that, "my father often mentioned the Nobel Prize as a worthwhile goal" (chap. 19, p. 193). Married for 49 years to Kay Tsuchida, whom he met at a dance put on by the University of Toronto's Nisei Students Club (chap. 19, p. 
When, in his last decades, Jack turned to a biography of his father, he created another enduring legacy. Through this careful telling of his father's life, Jack expresses love and admiration, and conveys the particular ways in which this remarkable family story lives on in memory. 


\section{References}

Adachi, K. (1976). The Enemy that Never Was: A History of the Japanese Canadians. McClelland \& Stewart.

Adams, Eric, Jordan Stanger-Ross, and Landscapes of Injustice Research Collective. (2017). Promises of Law: The unlawful dispossession of Japanese Canadians. Osgoode Hall Law Journal 54(3).

Atkinson, D. (2015). Out of one borderland, many: The 1907 anti-Asian riots and the spatial dimensions of race and migration in the Canada-U.S. Pacific borderlands. In Bryce, B. \& Freund, A. (Eds.), Entangling Migration History: Borderlands and Transnationalism in the United States and Canada (pp. 120-140). Florida University Press.

doi: $10.5744 /$ florida/9780813060736.003.0005

Ayukawa, M. M. (2008). Hiroshima Immigrants in Canada, 1891-1941. University of British Columbia Press.

Belshaw, J. D. (2009). Becoming British Columbia: A Population History. University of British Columbia Press.

Bird Commission Report. (1950, March 24). (Box 8, File 8). TFRBL, F.G. Shears Collection, Thomas Fisher Rare Book Library, University of Toronto.

Custodian of Enemy Property. (1943, March 27). Correspondence to Carl M. Stewart. (RG33-69, Vol. 73, Case file 1388, [p. 571]). Library and Archives Canada, Ottawa, Canada.

Deep Bay Logging Company Limited. (1942, April 14). Memorandum. (RG33-69, Vol. 73, Case file 1388). Library and Archives Canada, Ottawa, Canada.

Dominion policy in favor of influx. (1907, July 25). Vancouver Daily Province [VDP], p. 1. 
Fukawa, M., \& Fukawa, S. (2009). Spirit of the Nikkei Fleet: BC's Japanese Canadian Fishermen. Harbour Publishing.

Geiger, A. (2011). Subverting Exclusion: Transpacific Encounters with Race, Caste, and Borders, 1885-1928. Yale University Press.

Gilmour, J. F. (2014). Trouble on Main Street: Mackenzie King, Reason, Race, and the 1907 Vancouver Riots. Allan Lane.

Izumi, M. (1999). Lessons from history: Japanese Canadian civil liberties in Canada. The Journal of American and Canadian Studies 17, 1-24.

Kagetsu, E. (1942, May 22). Statement. (RG33-69, Vol. 73, Case file 1388). Library and Archives Canada, Ottawa, Canada.

Kagetsu, E. (1946, December 2). Correspondence to Custodian of Enemy Property. (RG33-69, Vol. 73, Case file 1388, [p. 588]). Library and Archives Canada, Ottawa, Canada.

Logging Company Assets for Sale. (1943, August 5). [Clipping from the Comox Argus]. (RG33-69, Vol. 73, Case file 1388. [p. 332]). Library and Archives Canada, Ottawa, Canada.

Order-in-Council, P.C.1942/2483. 27 March 1942. (File 2531G, Vol 1752, RG2 A-1-a). Library and Archives Canada, Ottawa, Canada.

Order-in-Council, P.C.1943/469. 19 January 1943. (File 2710G, Vol 1789, RG2 A-1-a). Library and Archives Canada, Ottawa, Canada.

Morawska, E. (1993). From myth to reality: America in the eyes of Eastern European peasant migrant laborers. In D. Hoerder \& H. Rossler (Eds.), Distant Magnets: Expectations and Realities in the Immigrant Experience, 1840-1930 (pp. 241-63). Holmes \& Meier.

Morawska, E. (1999). Insecure Prosperity: Small-town Jews in Industrial America, 1890-1940. Princeton University Press. 
Notice of Calls for Tenders for Timber Area. (1943, April 8). [Clipping from the Vancouver Sun]. (RG33-69, Vol. 73, Case file 1388. [p. 208]). Library and Archives Canada, Ottawa, Canada.

Robinson, G. (2009). A Tragedy of Democracy: Japanese Confinement in North America. Columbia University Press.

Rosenberry, D. D. (1942, Augus 28). Correspondence to Deep Bay Logging Co. (RG33-69, Vol. 73, Case file 1388). Library and Archives Canada, Ottawa, Canada.

Roy, P. (1989). A White Man's Province: British Columbia Politicians and Chinese and Japanese Immigrants, 1858-1914, University of British Columbia Press.

Roy, P. (2007). The Triumph of Citizenship: The Japanese and Chinese in Canada, 1941-67. University of British Columbia Press.

Stanger-Ross, J., Sugiman, P., \& Landscapes of Injustice Research Collective. (2015). Japanese Canadians in the Second World War. In Belshaw, J. D. Canadian history: Post-confederation. BCcampus Open Textbook. Retrieved from https://opentextbc.ca/postconfederation/chapter/ japanese-canadians-in-the-second-world-war/

Stanger-Ross, J. \& Landscapes of Injustice Research Collective. (2016). Suspect properties: The Vancouver origins of the forced sale of JapaneseCanadian-owned property, WWII. Journal of Planning History 15(4), 271-289. doi: $10.1177 / 1538513215627837$.

Stanger-Ross, J., Blomley, N. and Landscapes of Injustice Research Collective (2017). 'My Land is worth a million dollars': How Japanese Canadians contested their dispossession in the 1940s. Law and History Review, 35(3).

Stewart, C. M. (1942, November 25). Correspondence to P.S. Ross \& Sons. (RG33-69, Vol. 73, Case file 1388). Library and Archives Canada, Ottawa, Canada.

Sumida, R. (1935). The Japanese in British Columbia. (Master's thesis, University of British Columbia, Vancouver, BC). 
Sunahara, A. G. (1981). The Politics of Racism: The Uprooting of Japanese Canadians during the Second World War. James Lorimer \& Co. Retrieved from http://www.japanesecanadianhistory.ca/Politics_of_Racism.pdf

Switzer, A-L., \& Switzer, G. R. (2012). Gateway to Promise: Canada’s First Japanese Community. Ti-Jean Press.

Takai, Y. (2011). Navigating transpacific passages: Steamship companies, state regulators, and transshipment of Japanese in the early-twentieth-century Pacific Northwest. Journal of American Ethnic History, 30(3), 7-34.

Takata, T. (1983). Nikkei Legacy. NC Press.

Ward, W. P. (1978). White Canada Forever: Popular Attitudes and Public Policy Toward Orientals in British Columbia. McGill-Queens University Press.

War Measures Act, RSC 1927, c 206. 
CHAPTER 1

\section{Hard Life of a First Born}

\section{The Origin of the Name Kagetsu}

1 Leonard, 1968, pp. 137-146, 161-162; Kennedy, 1963, pp. 76-91;

Seidensticker, 1962, pp. 29-30.
$\mathrm{T}$

he period called "Country at War" began in 1500 during a time of civil war in Japan in which regional centers of power were sufficiently threatening to one another that they had to destroy others to survive. From the mid-16th century, a movement toward national unification gradually emerged out of the violence of the warring feudal domains. Three men, Oda Nobunaga (1534-1582), Toyotomi Hideyoshi (1537-1598) and Tokugawa Ieyasu (1543-1616) contributed to this unification. Oda Nobunaga won two important battles but was assassinated. Toyotomi Hideyoshi assumed Oda Nobunaga's power and successfully destroyed his enemies or won them over to his side and completed the unification of Japan by 1590 .

Tokugawa Ieyasu, Toyotomi Hideyoshi's successor, moved the shogunate headquarters from Kyoto to Edo (now Tokyo) and was appointed shogun in 1603 to begin the Tokugawa period. Tokugawa Ieyasu directly controlled Edo and the heartland of the country while the feudal lords controlled the 250 or so domains. The shogun believed that foreign secular and religious influence was a threat to his authority and therefore, in 1633 the shogunate issued the Exclusion Decrees that essentially isolated Japan from the rest of the world. During the next two and a half centuries, the Tokugawa shogunate was able to hold onto power by setting up the mechanism to maintain internal security and by indoctrinating the populace to the creed of loyalty and conformity. ${ }^{1}$ 
A decade and a half after the United States sent Commodore Matthew Perry to demand commercial relations with Japan in 1853 , the Tokugawa shogunate collapsed. Clans supporting a return to the imperial house prevailed and loyalties were transferred to the young Emperor Meiji. Under the long reign of Meiji from 1868 to 1912, the modernization of Japan rushed ahead and Japan became a world power.

During the 17th century, a daimyo (feudal lord) of a domain in Yamato in central Japan, had a very talented artist who entertained his court with haiku (a form of Japanese poetry) stories, songs, and musical instruments. He performed the tea ceremony graciously and produced beautiful calligraphy. The daimyo was very pleased with this artist's performance. As a reward he granted him the privilege of selecting his own surname. He chose the characters for hana (flower) and tsuki (moon), when combined into a name, pronounced as Kagetsu, and became the first in the line of Kagetsus.

The first known ancestor, Bunemon Kagetsu, lived at the end of the 18th century in Yamato, a city south of Kyoto. He had a son, Bungoro who in turn had a son, Hisakichi Kagetsu who was born in March 1859. Hisakichi was an itinerant medicine salesman.

\section{Eikichi's Early Years}

Yoshi, the daughter of a farmer named Tsuchiya, was born in December 1861. Hisakichi moved from Yamato to Kishu-the old name for Wakayama Prefecture that was formed in 1871-to sell medicine. He married Yoshi and settled in Yukawa-mura (village), Hidaka-gun (county). Their first son, Eikichi, was born on September 5, 1883. They had 10 more children: Tsune and Masano (adopted), Kiunosuke, Uta, Kiku, Katsu, Kimi (died seven days after birth), Tsurutaro, Kamenosuke (Tsurutaro's twin who died soon after birth), and Tome. $^{2}$

Their humble home, a one-storey house, had a simple thatched roof. The entrance was a dirt walkway that went through to the back yard. On the right of the entrance was the room where guests were received. There was a wooden landing where shoes were removed before stepping up onto the floor. There was a back room where the lady of the house performed her work. It had a small kitchen, a toilet, and a lot of storage space. Buckets were used to carry water from the well. On the left, there were two large rooms with lots of closets to store futons that were brought out at night for sleeping.

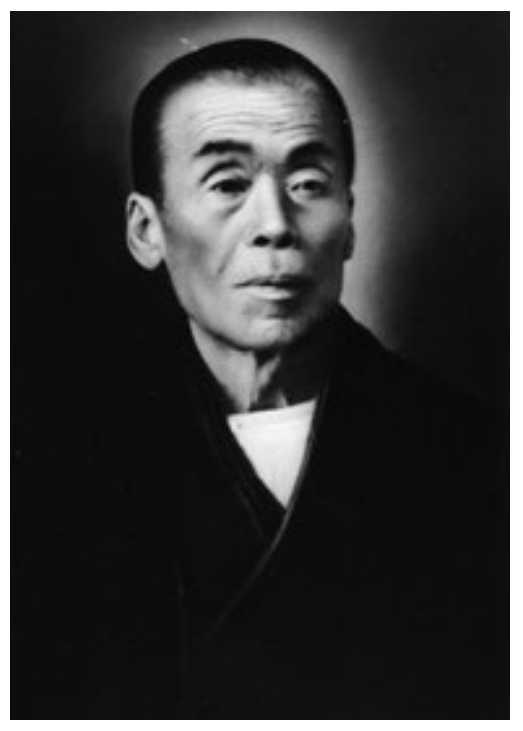

Hisakichi Kagetsu, Eikichi's father.

2 Koseki Tohon [Family Register], Gobo, Wakayama Prefecture [Municipal Government], Japan. 
Cotton was most commonly used for clothes and silk was only for the wealthy. On special occasions, men wore a fold-over coat with the family crest, trousers and cloth belt. Women also wore a fold-over full-length coat and a wide cloth belt over undergarments. For everyday use in the summer, bathrobetype kimonos were worn by the women and the more simple yukatas by the men. For walking outside, straw sandals or wooden clogs were used. During the winter, they wore cotton-filled quilted full-length coats. For school, the girls wore a fold-over half coat and loose-fitting trousers. The boys wore western style trousers that matched the color of their tunics. ${ }^{3}$

Because of the mountainous terrain and poor roads, foodstuffs, clothing, and other necessary items were transported in by boat. There were no large vegetable gardens because of limited arable land. Most households raised chickens and consumed their meat and eggs. Hisakichi raised and sold chickens. In those days, even for the well-to-do, the staple food was mainly a mixture of 70 percent barley and 30 percent rice. Only on special days such as New Years did the family enjoy white rice that they considered a "feast." Even at that, barley "rice" was eaten only at noon. In the morning and at night, they ate okayu (gruel) made of barley that was considered a substitute staple in Wakayama Prefecture. There was the barley okayu, green tea mixed chagayu, and also the white rice okayu. Occasionally, beans or sweet potato were mixed into the okayu. Families that ate okayu were considered fortunate. During different seasons, different foodstuffs were grown. In autumn, they ate matsutake-gohan (sliced fresh mushroom from the forest cooked together with rice). They also mixed various types of yam and beans or peas into the rice before cooking. Sometimes, they mixed in seafood caught in season such as mackerel, squid and sauri. My father's family attended the Tenshoji Buddhist Temple. In Japan, they didn't go to the temple every Sunday. They only attended the temple for anniversaries of death, etc.

As part of the "Meiji Restoration," the educational system in Japan was expanded and in 1872 universal compulsory education at the primary level for three years was established. Higher education was provided for those capable of taking advantage of it regardless of social status. ${ }^{4}$ Educational systems in the United States and Europe were studied and Western culture and knowledge

3 Yura-cho Tsu-shi Tien, (n.d.), Vol. 2

4 Kodansha, 1983, Vol. 2, pp. 171-178.

Kagetsu, K., (n.d.), [My Life] were widely accepted. However, the Japanese made sure that the traditional Japanese code of ethics was taught. Loyalty and obedience toward one's parents was emphasized. The students were imbued with patriotism and with faithfulness and undying loyalty to the Emperor, the symbol of the Japanese nation.

Eikichi attended the local Yukawa elementary school. His younger sister, Kiku, wrote: ${ }^{5}$ 
I feel sorry for my brother who was born the eldest son in a family with so many siblings. We were poor so his schooling was not adequate. He only went to the third grade in elementary school.

Eikichi was sent to Osaka to work in an artificial flower store to help support the family. Later, he made and sold artificial flowers at home to earn extra money for the family. Kiku recalled:

My brother was truly a good person. Even when I was small, I had great respect for him. Other people also respected his ethic of work. Once a beggar about 27 or 28 years old came to our door. My brother always had a one rin perforated coin on a nail and if the beggar was an old man he'd give him the coin. But to this younger beggar he said, "you are still young. It's better that you find some work", and he did not give him the coin.

Hisakichi was very caring towards his children. Kiku said that if she had something to ask, she would rather go to her father than to her mother. On the other hand, she was close to her mother and helped her in many ways. She was rather outspoken, so my father told her to keep quiet and go to school. When Kiku wanted to quit school so that she could get a job, my father discouraged her and urged her to continue her studies. She was always scolded by her older siblings. With so many children in the home, there was constant quarreling among them.

Tobacco was introduced into Japan towards the end of the 16th century by Portuguese traders. Although a large amount of tobacco was imported, it was also grown in a number of prefectures including Wakayama. The leaves were gathered and cured. One business consisted of cutting the cured leaves and selling the tobacco.

Aunt Kiku fondly continued:

At about age 19, my brother started making tobacco. He learned the trade somewhere and started his own business. He employed 5 or 6 workers and had a little shop. It was small but he must have needed capital to start his business and all the more I thought my brother was the greatest person I'll ever know. He was a caring, generous brother to us siblings and there is not a day when I don't remember him. 
6 Kagetsu, K. (n.d.). Watakushi no Jinsei [My Life]. (n.p.).

7 De Garis, 1950, p. 538.

8 Martin, 1967, pp. 38-69, 84-92.

9 Westwood, 1986, p. 123

10 Martin, p. 189; Warner, 1974, p. 466. Stated 275,000 infantry men and 16,000 cavalry.

11 Martin, p. 190
Eikichi would invite a few potential customers to the local pub. After enjoying a few drinks, he would bring out his order book. His friends would usually oblige him and place an order. At home, his younger brother or sister would fill the order. This was an early indication of his entrepreneurial talents. ${ }^{6}$

The Japanese smoker used a tiny tobacco pipe that consisted of three parts: a small metal bowl, a long hollow stem made of a special kind of bamboo, and a mouth-piece. The tobacco was carried in a leather pouch that hung from the smoker's sash. He also carried a portable case that held a small fire brazier with live charcoal to light the pipe. The smoker filled the bowl with a pinch of tobacco, ignited it and enjoyed a few puffs. Needless to say, the smoker was kept busy re-filling his pipe. ${ }^{7}$

\section{The Russo-Japanese War}

Outside of Yukawa village, on the world scene, the Russo-Japanese War was declared on February 10, 1904. Japan needed raw materials and markets while Russia wanted to expand into East Asia. After the Japanese army secured a foothold and a port in Manchuria, they won a series of battles forcing the Russians to retreat northward. Each army suffered high casualties of 50,000 to 60,000 men in these early battles. ${ }^{8}$ In Japan, men were being drafted in large numbers to fill the military's requirements.

My father was drafted on September 29, 1904 into the 37th Infantry Regiment of the First Army Reserves. His army training was brief before he boarded a ship at Osaka and landed at Dalny port in Manchuria on November 22. Five days later, he proceeded to the battlefield at Hungling Pao to join the 37th Infantry Regiment, First Army. Training the new recruits was a serious problem because experienced officers were required at the front. The training period for my father was reduced. ${ }^{9}$

By the end of November, the Russian Army stationed in the Mukden area assembled the greatest force in history, 210,000 soldiers, divided into the First, Second and Third Manchurian Armies. ${ }^{10}$ They continued to suffer from shortages of supplies due to bad planning by headquarters, and the difficulty of receiving supplies over a single-track railway halfway across the world. For the assault on Mukden, the Japanese had amassed about two hundred thousand troops assigned to the First, Second, Third, Fourth, and Fifth Armies. ${ }^{11}$ The First Army that included my father's regiment, battled the Russians at Central Sanchiatzu on 
December 5, at Linchengbao on December 25 and at Hungling Pao on December 29. My father considered these minor skirmishes.

After a five month siege of Port Arthur and numerous attacks by the Japanese, the Russians decided that their position was untenable and surrendered on January 2, 1905. It was a costly victory for the Japanese who suffered sixty thousand casualties. ${ }^{12}$ On January 19, the Russians attacked "to strike a decisive blow against the Japanese before the Third Army from Port Arthur could be brought into action in the north." The Battle of Sandepu was fought in the Heikoutai area and lasted from January 26-29, 1905. The First Army, to which my father belonged, and the Second Army fought together. The Russian intelligence was confused and the Russian forces were ordered to withdraw. ${ }^{13}$ The largest and final battle, the Battle of Mukden, began with the first clash on February 18. My father was sent to the front on February 22 to join the Fourth Army. The next day there was a snowstorm, but this did not prevent the Japanese from attacking. There were attacks and counter-attacks along the ninety-mile front. Between March 4-8, the Fourth Army met "fierce Russian resistance" and made a little progress. ${ }^{14}$

On March 9, the Russian command decided to retreat to Tiehling, the next big town north of Mukden. It was a wild and stormy day. A southwesterly gale swept across the battlefields all day long, sometimes raising clouds of dust that made it impossible to see for more than a hundred yards. The Japanese First, Fourth, and Fifth Armies were ordered to continue the pursuit of the First and Third Manchurian Armies of the Russians. ${ }^{15}$ It must have been quite an ordeal for my father and the troops on both sides. Not only did they have to worry about being killed, but hunger and the bitter cold added to their suffering. The Battle of Mukden cost the Japanese 70,000 casualties and the Russians lost 90,000 men. ${ }^{16}$

My father's regiment began defending the captured Mukden area. They were encamped at Shilichetou and later at Gujiazi. On March 22, my father was assigned as active duty private first class in the Second Army and was stationed west at Qinyunbao. On May 27, he was returned to his original Company at Waishihyuantzu and in June was stationed at Pienchiakow. On June 9, his regiment was assigned to defend the front line about 100 miles northwest of Mukden at Gaojiawopeng.

Forty years later when he wrote his recollections of the war, he wrote the place names using the complicated Chinese characters. His third-grade education did not teach him Japanese characters that complicated. One might conclude that he had a "photographic" memory!
2 Martin, 164-188

13 Martin, pp. 190-193.

14 Warner, p 469; Martin, pp. 195-202.

15 Martin, p. 202; Warner, p 475.

16 Martin, p. 207. 
On land, the Japanese had won all the battles and likewise at sea the Russian's Far East Fleet and the vaunted Baltic Fleet were defeated. On June 9, 1905, President Theodore Roosevelt's ambassadors urged the Japanese and Russian governments to open peace negotiations. The Russians now had 446,00o front-line soldiers in Asia and the Japanese had increased their fighting men up to 360,000. "The Russians did not want to fight anymore, and neither did the Japanese." The Russian navy was destroyed. "The Japanese were exhausting their financial and human resources." ${ }^{17}$ On August 6, 1905, representatives from both sides met at Portsmouth, New Hampshire and began negotiations on board the Presidential yacht, Mayflower. The Treaty of Portsmouth was signed on September 9, 1905. President Theodore Roosevelt received the Nobel Peace Prize for his part in the peace negotiations.

My father was lucky to have survived. His defense duties ended, but he stayed on at Gaojiawopeng until December 14 when he boarded a ship at Liushuto. Three days later, the ship disembarked at Wadasaki, in the prefecture of Hyogo. He marched in the triumphal military review at Osaka Castle, and was subsequently discharged from the army on December 22, 1905. For his military service, he was decorated with the Eighth Order of Merit and the Order of the White Paulownia Leaf. 
TREE TRUNK - MY PILLOW I KAGETSU 


\section{CHAPTER 2}

\section{Getting Started in a New Land}

\section{Eikichi Seeks a Better Life}

Eikichi Kagetsu-Canadian Pioneer. Continental Times, January 1, 1955.

2 Eikichi Kagetsu-Canadian Pioneer, 1955; Takata, 1983, p. 84.

3 Sumida, 1935, pp. 46-68; Adachi, 1976, pp. 16-28; Ward, 1982, pp. 3-17. ometime after Eikichi returned from the Russo-Japanese War, the Japanese government took over the tobacco industry. My father received compensation from the government for his tobacco business. The mountainous areas in Wakayama Prefecture were covered with trees. From early childhood, my father had been interested in timber. His uncle in Wakayama Prefecture had been engaged in this business and had taught his nephew about timber. ${ }^{1}$

As my father talked to men who had returned from Canada, he heard about the forests with their giant trees. Even though he was the oldest son and would inherit everything from his parents and had fulfilled his military service, he decided to go to Canada to seek a new and better life. ${ }^{2}$ He took 200 yen of the reimbursement from the government for this venture and, being a responsible son, he gave the balance of the windfall to tide the family over.

In June 1906, many young men said goodbye to their family, relatives, and their friends. There was much bowing but no kissing or hugging or even hand shaking as was customary with Caucasians. These young men had decided to go to America. Each man had his own reason for leaving. A recession followed the Russo-Japanese War and jobs were scarce. Many of them had friends or relatives in British Columbia. All of them wanted to improve their lot in Canada. ${ }^{3}$ Having 
said their good-byes, they made their way to the railroad station to travel to the nearest port, either Yokohama or Kobe. Their luggage consisted of a few clothes in a wicker trunk or wrapped in a cloth called a furoshiki. My father went to Kobe.

When they reached the dock, they were impressed by the sleek appearance of the Empress of China that conveyed an impression of speed and elegance. The ship had two centrally mounted funnels and three masts. A white hull and superstructure, buff upper works, ventilators and funnels, and pink boat-topping enhanced its looks. This ship, together with its sister ships, the Empress of Russia and the Empress of Japan, were the fastest and most luxurious passenger ships plying the Pacific at that time. ${ }^{4}$ Staterooms for a total of 160 first-class passengers were located in the upper airy parts of the ship, away from the noise and vibration of the machinery. Accommodations for 40 second-class and as many as 700 steerage passengers were allocated in the less desirable areas of the ship.

The Empress of China set sail from Kobe on June 6 and then from Yokohama on June 8. The passengers in steerage could sleep, converse with fellow passengers, or walk the limited deck space reserved for them. They must have felt a great sense of anticipation as they did not know exactly what they would find in Canada. As the ship crossed the Pacific ocean, my father and other Japanese immigrants must have shared what they knew of their destination. They knew neither the language nor the customs of their new home. Fortunately, many others had preceded them and lived in a particular part of Vancouver, British Columbia. One passenger recalled the food served on board, "There was ricenot very tasty-just all stirred up together in a wok. You were never full."

During the trip, the purser filled in the bill of lading with pen and ink. There were 159 first class, 27 second class, and 443 steerage passengers. Information on Eikichi Kagetsu was entered on page three and indicated that my father had \$39, a little more than the $\$ 25$ minimum set by the Immigration officials the following year. His age was erroneously recorded as thirty-two, instead of twenty-three.

There was much excitement aboard the Empress of China. Land had been sighted. The passengers in steerage did not have a good vantage point and probably did not see land at that time. Nonetheless, they were more excited than the first class passengers because everything was going to be new for them. Vancouver Island with its lovely mountains loomed into sight. The ship entered the Strait of San Juan de Fuca and passed Cape Flattery during this fifty-mile run along the Vancouver Island coastline. The numerous islands and inlets must have reminded the Japanese passengers of the coastline of their homeland. As they got closer to the mainland, the beauty of the Coast Mountains must have impressed them greatly. In the far distance, the snow-covered Mount Baker formed a beautiful picture as it rose up through the clouds into the heavens. ${ }^{6}$
4 Turner, 1981, pp. 23, 26.

5 Turner, p. 40. For a different experience see: Japanese Canadian Centennial Project, 1978, p. 7.

6 Haldane, 1900, p. 261-262. 
A Vancouver newspaper reported that the Empress of China was sighted off Carmanah at $4 \mathrm{am}$ and should arrive in Vancouver by $4 \mathrm{pm}^{7}{ }^{7}$ The passengers were treated to the matchless beauty surrounding the Empress of China as it passed through the Strait of Georgia toward Vancouver. Then they cleared the narrow strait off Stanley Park and entered Vancouver harbour. Giant trees could be seen in all their majestic detail. My father must have been greatly impressed with them.

After docking, the first class passengers disembarked first. It is possible that the steerage passengers were not let off the boat until the next day because of the large numbers. A translator, who was Japanese, was available to help the Japanese passengers through Canadian immigration. On occasion, an unscrupulous translator would shake down the passengers by asking for a cash handout. If the unwary passenger refused, the translator by innuendo could make it difficult for the passenger to clear immigration.

Somehow, my father found his way to the Japanese section on Powell Street. Between Columbia Avenue and Carl Avenue (now known as Princess Avenue), the Japanese owned numerous rooming houses, boarding houses, and cabins where my father found a place to stay. There were stores selling groceries, Japanese goods, clothing, and other general merchandise. ${ }^{8}$ A Japanese newspaper called Canada News was printed by Rev. Goro Kaburagi. The streets were unpaved. The local newspaper described the sockeye salmon running in the Skeena, the shortage of Indian fishermen, and the influx of Japanese fishermen in Steveston. ${ }^{9}$ My father, not being a fisherman, did not come to Canada to fish. However, I can imagine him enjoying salmon teriyaki for one of his first dinners in Canada.

7 Empress of China Inward-Bound, Vancouver Daily Province, June 19, 1906.

8 City of Vancouver Directory, 1906, 1907, 1912; Kluckner, 1993, pp. 29-30. For a description of early Vancouver see: MacDonald, 1992.

9 Empress of China Inward-Bound; Many Japanese Come to Fish, Vancouver Daily Province, June 19 \& 23, 1906.

10 Wyngaert, (n.d.).

\section{Work to Amass Capital Funds}

My father recalled,

I rested for two or three days thinking about what business to undertake. I realized that whatever I did I would need capital. I immediately took a job at Sechelt in a sand mine.

A local resident in Sechelt described the sand and gravel operation as follows: ${ }^{10}$ There was a small encampment of Japanese men above [the] tidewater on the Hopkins 16 acres [which is about 14 miles east of 
Sechelt].... They were engaged in loading beach gravel onto scows for [the] Champion \& White Company of Vancouver. The scow would be beached, on end facing shoreward, and thus moored. Heavy planks, used as a ramp, were run ashore from the scow. With wheelbarrow and shovel, these Japanese began their arduous task, dumping their loads at the extreme end of the scow and gradually working back to the shore end of the scow. It took a long time to so load a scow. When completed a tug would arrive from Vancouver to pull the scow from its mooring and thence to Vancouver.

This was backbreaking work.

In the meantime, my father kept his eyes open for a better job. The Britannia Mines was located approximately 32 miles north of Vancouver on the eastern shore of Howe Sound and eventually became the largest copper producer in the British Empire. Britannia Mines began hiring Japanese workers in 1903 to work on a variety of projects. ${ }^{11}$ The method of mining used originally was found to be inadequate and dangerous. Consequently, plans were made to use the square-set method in which timber sets were installed to prevent cave-ins as the ore was mined. In order to supply the required timber, logging and sawmill operations were organized. ${ }^{12}$ In 1906, fifty Japanese labourers were hired to supply logs to the sawmill and to operate it.

In October 1906, the Japanese labour boss from the Britannia Mines hired my father for one of those jobs. He packed immediately and boarded the Britannia, the boat that carried supplies and mail to Britannia Beach. He was probably assigned the job of a logger and got his first taste of logging working for the Britannia Mines. His $\$ 1.75$ daily wage was considered very good at that time. ${ }^{13}$ The Japanese working for Britannia Mines were treated well. There were three boarding houses in the Company town, one for the Japanese workers, one for the Chinese workers, and the third for the Caucasian workers. Workers with families, including the Japanese, were assigned individual homes. Food and dry goods that included work clothes could be bought at cost at the Company store. The Caucasian and Japanese workers got along very well with no discrimination. ${ }^{14}$

In 1907, there was a dramatic reduction in the number of Japanese workers at the Britannia Mines. During this period, the Company was modifying the mining and milling systems in an attempt to turn the operation around to produce a profit. Some or all of the reduction in labour force may have been to lower costs. For whatever reason, my father left in May.
11 Nakayama, 1921b, pp. 901-914. Nakayama is a valuable source of Japanese Canadian History. See Armor 2000, pp. 31-68, 84-169, 189-276; Shibata, 1977, pp. 34-36.

12 Hovis, 1986, p. 69

13 Nakayama, pp. 901-914.

14 Backus, 1969, p. 137. 


\section{CHAPTER 3}

\section{Early Logging Ventures}

\section{Getting Started in Logging}

$1 \mathrm{y}$ father described the forests in western British Columbia as follows:

West of the Rockies towards the Vancouver area are Douglas fir and cedar, some of which are gigantic trees estimated to be 800 years old, many are 15 to 16 feet in diameter and 200 feet high. Hemlock and larch, some of which are about 300 years old but most of which are about 150 to 200 years old, are about 120 or 130 feet high. ${ }^{1}$

When my father left his job at the Britannia Mines in May 1908, he thought:

I had saved some money so I went to Vancouver and was thinking night and day-British Columbia has the most prolific forest land in all of the world; looking in all directions there are dense forests of cedar, Douglas fir and other trees. Since the business would not require excessive labour and costs appear to be one-fourth of those

Kagetsu, Eikichi, (2000). Canada's Forests Major divisions: West-British Columbia ..., (Draft of a Speech/ Article," Trans. by Takako Huang).

2 Shibayama, 1941a, p. 164. in Japan, I came to a decision that this is the business I want to try.

He saw the limitless areas of timberland and thought that these logs would be of immense value to Japan as well as being a source of profitable business. ${ }^{2}$ 
From May to September 1907, he went to work for the Still Creek Logging Company. Still Creek flowed northward through what is now the city of Vancouver. In the early days, there was much logging activity in this area to supply logs to sawmills on the Burrard Inlet, while at the same time clearing land for the city. He had two objectives, one was to learn the business and the other was to accumulate capital.

An interviewer wrote: ${ }^{3}$

He knew very little English, let alone the manners and customs of the land. But the will to succeed burned brightly in him. The long hours, the exhausting labour that fell upon the shoulders of an immigrant worker were his lot. The fruits of hours and hours of blistering, numbing and back-breaking toil totaled but one or two dollars. Moreover, there was little steady employment to be had in the logging business which he had come to love. But with the insistent desire to learn the trade driving him onward, the future lumber magnate went from camp to camp hunting for work and always got it!

Kagetsu related, "I worked at various logging camps, spurred on always by a vision of the future. By that time, I had managed to put aside about four or five hundred dollars and having taken quite a shine to the logging business myself, I decided to try my hand at it."

\section{Camp at Sechelt}

The area known as the Sechelt Peninsula was located approximately 50 miles northwest of Vancouver. The Hastings Sawmill on the Burrard Inlet and other sawmills sent out crews to this area to harvest the choice timber. In 1907, a store was built at the mouth of near-by Roberts Creek. A steamer from Vancouver brought mail and supplies for the store and the owner rowed out on his skiff to pick them up. ${ }^{4}$ Japanese loggers appeared about this time to cut shingle-bolts on the west side of Roberts Creek. A suitable cedar tree was felled and cut into 8.5-foot lengths that were split into shingle bolts. They were transported to a dock on horse-drawn sleds and loaded onto scows that were pulled by a tug boat to the sawmill. At another location, a second group of Japanese cutters dumped their shingle bolts into a pond that fed the flume. ${ }^{5}$

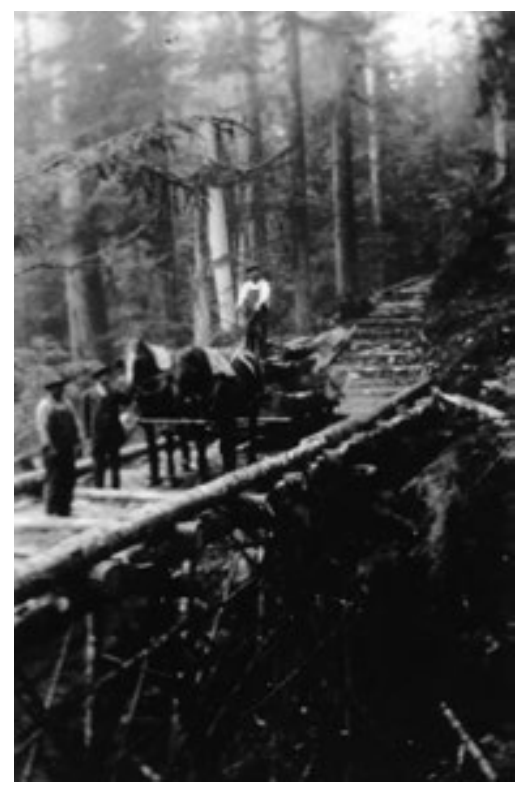

Hauling logs from E. Kagetsu's logging operation.
3 The New Canadian, April 5, 1940.

4 Dawe, 1990, p. 51; Rushton, 1978, p. 25.

5 Roberts Creek Historical Society, 1978, pp. 33-34, 66 
Roberts Creek Historical Society, p. 34.

7 Different dates have been mentioned as follows: Continental Times, January 1 , 1955: 1909; Continental Times, January 1, 1977: 1907; Nakayama, 1921a, p. 930.

8 Shibayama, p. 164

9 Kobayashi, n.d.

10 Roberts Creek Historical Society, p. 67.
The Japanese workers built their camps in the woods beside a creek far away from other groups. They spoke Japanese and cooked their ancestral foods.

There were several Japanese families with children in the camp. They lived in houses built of cedar shakes. On the bank of the Creek they built a bathhouse on poles over a big square iron tub. Every day the children would fill the tank by dipping water from the Creek. The women would build a fire under the tank to heat the water for the men's communal bath that they enjoyed on their return from working in the woods. ${ }^{6}$

While working in the sand and gravel operations at the beach, my father got to know some of these Japanese loggers and learned the details of their logging operations. When the time came, he decided to start his first logging venture in the Sechelt area. He recalled:

I was determined to work hard; investing my precious little savings I bought some timberland that was for sale and thus I began my logging business.

In September 1908 my father paid $\$ 200$ as the first installment for the timber rights to 160 acres of timberland at Sechelt. ${ }^{7}$ He probably continued to work while he prepared to start up his first logging operation almost a year later. Since he was in a foreign country and didn't know the laws and procedures, my father went through difficult times in the beginning. ${ }^{8}$ He must have hired a lawyer to help him purchase the timberland and to advise him on regulatory matters, such as obtaining the necessary licenses, etc. In the meantime, his mother arrived from Japan to help him with such activities as cooking meals for the workers, etc. ${ }^{9}$ Finally, in August 1909 he was ready. Together with his mother and a crew of loggers he boarded a Union Steamship Company boat. In those days, it was not possible to travel up the coast by land. Four horses, saws, axes, other equipment and provisions were transported on the ship.

The first order of business was to decide on a campsite. A large cedar tree was cut down, cut to length and split to make beams and shakes with which to build living quarters. At first, the operations were small and makeshift. He sold the Douglas fir logs to a local sawmill and immediately showed a profit which was described as "pitifully meager." It had been reported that "[b] etween 1907 and 1908, the Archibald place was partly logged with horses by some Japanese." ${ }^{\prime 10}$ This description fit my father. Later, shingle bolts and logs were 
sold to sawmills in Vancouver. By February 1910, all the saleable logs had been hauled out. An entry in my father's journal states, "[d]uring this period gained substantial profit and experience."

\section{Camps at Blind Creek and Myrtle Point}

Blind Creek, located on the southeast end of Cortes Island, is actually a bay. Today, it is called Cortes Bay. In March 1910, my father bought 640 acres of timberland at Blind Creek. ${ }^{11}$ When he first started, he sold the output to sawmills in Vancouver. In 1911, a town site for the new Pacific terminus of the Canadian Northern Railway was laid out east of New Westminster. My father's journal entry for October 1910 stated:

At the upper part of the Fraser River, a new town called Port Mann is being built and a large quantity of cedar pilings will be needed for bridge building. Immediately [I] made a sale and transported same by tug boat. In January 1911, the Fraser River froze over so severely that the cables tying the logs were severed and all the pilings eventually were lost. With the ice breaking up before our eyes, the current was so strong there was no hope of recovery operations. Since this happened before the government had surveyed the measurements, it was not even possible to claim compensation-this is was a total loss.

He lost \$10,000 worth of logs on the Fraser River. ${ }^{12}$ Although the remaining timber at Blind Creek, horses, and equipment were all sold, the business was in the red and failed. It was a very difficult time. Also, customers failed to pay their bills due to a severe economic recession. The demand for timber was slowly decreasing and prices were getting lower and lower. My father had bought some timberland at Myrtle Point, located on the coast southeast of Powell River, and operated it at the same time as the Blind Creek operations. My father's recollections only mention that between March and July 1912, logging operations at Myrtle Point failed.
11 Different dates have been mentioned as follows: Nakayama, p. 930: 1908. Shibayama, p. 164: 1910; Continental Times, January 1, 1977: 1908; Continental Times, January 1, 1955: 1912.

12 Nakayama, 1922, p. 32. 


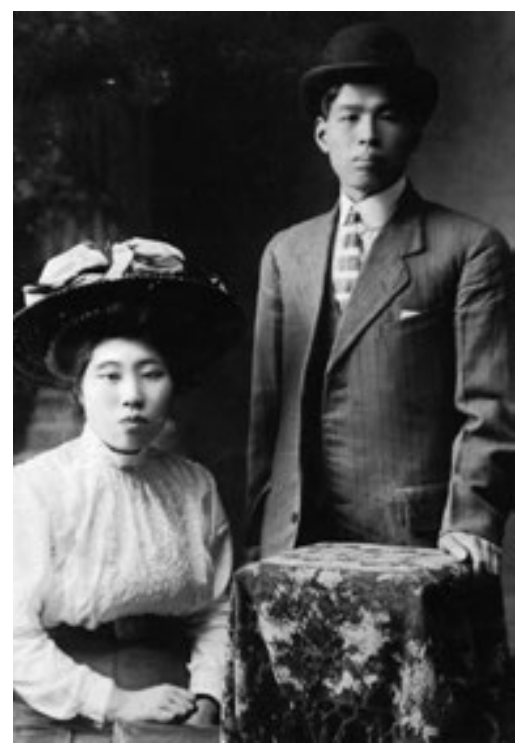

Eikichi Kagetsu married Toyo Nakamoto.
13 Kobayashi.

14 Kobayashi. This house is not listed in the City Directory.

\section{Marriage to Toyo Nakamoto}

Shozaimon and Ei Nakamoto lived in Ena-mura (village), Wakayama Prefecture, which was on the Sea of Japan, close to where my father was born. They were successful in farming and fishing and had six children: Katsutaro, Shotaro, Rikimatsu, Naoe, Torino, and Toyo. The first three were boys and the last three girls. Toyo, the youngest child in this well-to-do family, was born in 1892 and led a pampered life. She attended elementary school for six years. She had to be accompanied over a small mountain by her father or by someone else while she attended a girl's school for another three years. She went on to earn a teacher's certificate and taught at Ena-mura for a few years.

However, her brother Katsutaro had lost much of the family wealth through gambling, and the family could not afford a dowry for her to marry a suitable man in Japan. Her parents heard of a young, hardworking, up-and-coming young man in Canada named Eikichi Kagetsu, who was looking for a wife. The marriage was duly arranged and they were married by proxy in Japan on May 2,1910 . This was done to ensure that the marriage was properly registered on their koseki tohon (official family register).

My grandmother, Yoshi, who was living at Sechelt, left Canada on the Sado Maru on October 8, 1910 and returned to Japan. ${ }^{13}$ On August 10, 1911, the young bride left Japan on the same ship accompanied by Yoshi, her motherin-law. They landed in Victoria on August 29. Two days later, Eikichi and Toyo were officially married by license at 732 Cormorant Street in Victoria by the Registrar, F. E. Hollings. My father was living at 899 Powell Street during this period. ${ }^{14}$ When logging operations at Myrtle Point failed, my father worked at various jobs and sought lodgings elsewhere. My mother recalled:

I arrived (in Canada) just when his first (logging) business had gone bankrupt. As a consequence, even though I was totally inexperienced in doing such things, I worked at a cannery and did housework at homes of Canadians.

Later that year, on October 20, 1912, their first child, a girl they named Hideko was born. My mother wrote:

Japanese proverb: nana korobi hachi oki-you fall seven times but for the eighth time ready for work again. I carried my baby and went into the woods for firewood. I had to wake up at 4 a.m. to go 
to work as a maid to a place quite a distance away. Even more than Dad, I went through all kinds of suffering. Even now there are people who say to me, "You really endured your hardships well."

I can remember my mother using the Japanese phrase "kurou shita" (suffered hardship) when describing those trying times. From 1912 to 1915, my father worked at various jobs with the sole objective of amassing some capital to rebuild his logging business. At first, he worked as a labourer at sawmills and logging camps, wherever there was employment. Later he did gardening work in the Point Grey area. ${ }^{15}$

\section{Camp at Blind Channel}

After many years of hard toil to accumulate capital funds, the economy improved and the timber business began to look good again. In 1915, my father resumed his business, Kagetsu \& Company, by buying timber land at Blind Channel on West Thurlow Island, located approximately 140 miles northwest of Vancouver. This area had good timber stands on its hilly terrain and a sawmill built in $1907 .{ }^{16} \mathrm{He}$ had to bring in equipment and a crew as well as horses for hauling and set up a camp. The Union Steamship Cassiar I and Cowichan stopped at Shoal Bay where there were stores and a hotel on the northern shore of West Thurlow Island. Loggers from sites around Blind Channel had to row to the steamship anchored in Cardero Channel to get their mail and supplies. ${ }^{17}$

My mother recalls:

I had a cousin, Saichiro Inouye, who worked at Obayashi Gumi, the number one lumber enterprise in Osaka. So at my suggestion, we wrote him a letter. He replied that we should send a sample shipment of timber immediately.

In March 1916, the first load of split cedar logs were shipped to Japan where the product received a good reception. My father was the first to export raw logs from British Columbia to Japan. There were repeated requests for more shipments. Exports of cedar timber were very profitable and so my father purchased additional timber holdings. In March 1917, 200,00o board feet of top quality split cedar logs for ceiling boards were exported to Japan in 3 ship-

15 Continental Times, January 1, 1955; January 1, 1976.

16 Nakayama, (Supplement), p. 32.

17 Anderson, 1979, pp. 156, 161, 162. 
ments. This first export to Tokyo, where timber brought good prices, was made to a wholesaler named Matsumoto.

\section{Camp at Roy}

Approximately 10 miles north of Blind Channel, on the west side of Loughborough Inlet, is a logging area called Roy. In August 1917, my father bought 640 acres of dense cedar forest at Roy. With four horses, they hauled out great quantities of logs that were exported to Japan. Throughout 1918, he continued to export large quantities of cedar logs for ceiling boards. According to my father's journal, in March 1919, forestry laws were revised to prohibit the export of British Columbia logs to protect domestic sawmills. He received permission from the Forestry Bureau to export what was already cut into split cedar logs. In order to get around the ban to export logs, my father rented a sawmill at the Hastings townsite to produce split cedar logs that could be exported.

\section{Legal Battle by Japanese Canadians to Continue Logging}

May 1, 1920 was the date on which the British Columbia (BC) government was going to begin enforcing a 1902 Order-in-Council that prohibited men of the "Japanese race" from working on Crown Land. ${ }^{18}$ Close to 2000 Japanese loggers whose yearly income amounted to some 2.5 million dollars would potentially be out of work. ${ }^{19}$ Since the forests at Roy were originally Crown Land, my father suspended logging at that site. A long and complicated legal battle

18 Oriental Orders-in-Council Validation Act, SBC 1921, c. 49.; British Columbia, Journals of the Legislative Assembly, 9th par, 3rd session, Vol. 31 (15 April, 1902) at p. 65

19 Canadian Japanese Association, Untitled Internal Report on Forestry Problem [In Japanese] (Vancouver, n.d.); Scantland, 1984, p. 28.

20 Yamazaki, 1942, pp. 201-205; The Canadian Encyclopedia, 1988. ensued. As it turned out, the British Columbia government agreed to withhold any enforcement until the legal questions were resolved and my father didn't have to curtail his logging operations.

The Canadian Japanese Association (CJA), under President Matsunoshin Abe, joined forces with the Japanese Forestry Workers Union, and conferred with three Caucasian organizations with common interests to retain Sir Charles Tupper (who was the Solicitor-General when his father was the Prime Minister in 1886), as counsel for the CJA. ${ }^{20}$ The Dominion government took the case against the $\mathrm{BC}$ provincial government to the Court of Appeals that unanimously declared, on November 16, 1920, that the Order-in-Council was 
ultra vires or exceeded its authority because it conflicted with the Japanese Treaty Act of $1913 .{ }^{21}$

The BC government passed the "Oriental Orders-in-Council Validation Act" on April 1, 1921, to confirm the 1902 Order-in-Council and its provisions. ${ }^{22}$ Sir Charles Tupper argued the case before the Supreme Court in Ottawa, and on February 7, 1922, the British Columbia law was declared ultra vires. ${ }^{23}$ The BC government appealed the decision to the Privy Council in England. On October 18, 1923, the Privy Council decided that the British Columbia Act prohibiting the hiring of Japanese ran counter to the provisions of the AngloJapanese Treaty and upheld the decision of the Supreme Court of Canada. ${ }^{24}$ Legal costs exceeded $\$ 16,000$ and were covered by donations from the public, money raised by Japanese logging camp owners, CJA contributions, and financial aid from the Foreign Ministry of Japan.

\section{Camp at Seymour Creek}

In what is now known as North Vancouver, both Lynn Creek and Seymour Creek meandered down into the valley between Grouse Mountain and Mount Seymour. The forests contained Western red cedar trees suitable for making shingle bolts. The growths of fir, hemlock, balsam, and spruce were of poor quality, probably because of the terrain and poor soil. The shingle industry grew rapidly after the turn of the century. Due to Western red cedar's durability, strength, and straight grain that facilitated splitting, British Columbia shingles gained a good reputation and wide acceptance. The Hastings Shingle Manufacturing Company built a mill on the North Shore in 1903 and extended its logging operation further up Lynn Creek and eventually to the Rice Lake area. Until the early 1920's, shingle bolts were transported by flume or by horsedrawn wagons. ${ }^{25}$

The following description is from a paper written for Capilano College by Naomi Yokota: ${ }^{26}$

The isolated clusters of early Japanese pioneers in North Vancouver...gathered along the mouths of Seymour River, Capilano River, and the few logging camps, saw mills and canneries that permitted them employment....Lynn Valley, a secluded small community was one such place where a handful of Japanese were employed in the manufacture of shingle bolts, consisting of
21 Volume 3 W.W.R., p. 937.

22 Statutes of the Province of British Columbia 1921 Chapter 49.

23 British Columbia (Attorney General) v. Canada (Attorney General), 192265 DLR., pp. 577-607; SCC (1922). In the Matter of the Authority of the Legislature of British Columbia to Pass an Act to Validate and Confirm Certain Orders-inCouncil and Provisions Relating to the Employment of Persons on Crown Property. Vol. 63, pp. 293-341; Hidaka, 1942, pp. 33-35. Mr. T. G. Norris, K.C. wrote a memorandum explaining the important points in this case.

24 A.C. House of Lords and Privy Council, pp. 203-313.

25 Kahrer, 1988, pp. 38-39.

26 Yokota, 1994, pp. 6-7. 
Japanese contractors and workers camped along Lynn Creek around 1915 .

Japanese loggers built a camp on a mountain slope at Rice Lake near the Cedars Limited Mill. The loggers lived there with their families. ${ }^{27}$

In June 1920, in order to get around the prohibition of Japanese working on Crown land, my father bought 160 acres of privately owned timberland at Seymour Creek on the North Shore. He may have selected this timber area because he knew that Japanese loggers were readily available in the area. He built a field office and other buildings, including a bunkhouse and mess hall. One of the timber properties, Lot 922, was actually Crown land and was located just above the present intake for the water system that supplied the City of Vancouver. My father received a permit from the City of Vancouver to use a road along the water reservoir to transport logs to Burrard Inlet. He had to build a road to tie into the existing road. At least one bridge had to be built to cross one of the creeks. By this time, my father owned a car and was able to drive to the camp and work areas.

My father transported four horses from Roy to Seymour Creek to be used for hauling logs. The cut logs were loaded onto sleds and pulled by horses over skid roads to the timber assembly area. Equipment was located at the timber assembly area to produce split cedar logs. He bought two trucks to transport the logs to the "storage" area on the waterfront. Whole logs were sorted and made into booms and split cedar logs were loaded onto barges. These were hauled to a sawmill or to a dock in Vancouver where they were loaded onto ships bound for Japan.

In 1921, he bought an additional 480 acres at Seymour Creek and built more roads. In March 1921, my father chartered Yomei Maru to export great quantities of cedar logs, Douglas fir logs and Douglas fir square timber. In June 1921, he exported great quantities of Douglas fir logs, and Douglas fir square timber via several steamships; this major export shipment "set a precedent." Hauling logs at Seymour Creek was completed in May 1924. The Greater Vancouver Water District was incorporated in December 1924 and eventually prohibited logging in the watershed. ${ }^{28}$

In the 1920's, there was a small independent sawmill in the Seymour Creek area that was owned and run by Mr. S. Naruke who employed eight Japanese

27 Draycott, 1978, p. 26.

28 Kahrer, 1989, pp. 39, 45.

29 Yokota, pp. 6-7. workers. ${ }^{29}$ My father bought the sawmill in October 1920 for $\$ 25,000$. Independent Japanese loggers supplied logs for the sawmill. After May 1924 my father's logging operations at Seymour Creek ceased. Eventually the sawmill was sold. 


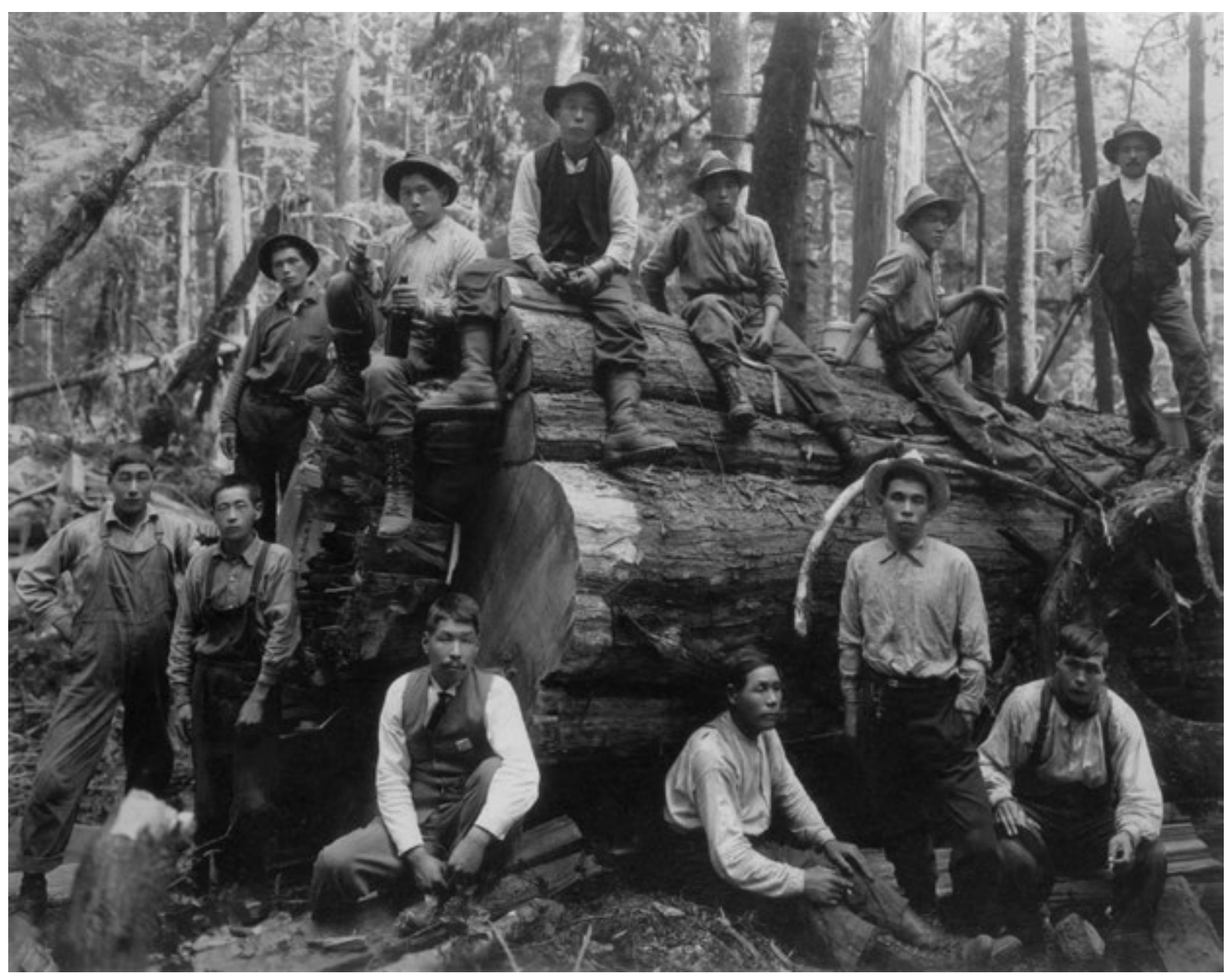

\section{Camp at Bowen Island}

Eikichi with workers around a giant cedar log at Seymour Creek.

Bowen Island is located across the Queen Charlotte Channel, due west of Horseshoe Bay at the entrance to Howe Sound. It covers an area about seven and one half miles long and three to four miles wide. The sawmills along the Burrard Inlet and the one at Chemainus on Vancouver Island considered the 
timber on Bowen Island to be an excellent source because of its proximity and because the terrain for logging was not as steep as in other locations. The Victoria Lumber and Manufacturing Company and others began extensive logging during the first decade of the 2oth century. Japanese worked at logging and shingle bolt camps.

George H. Cowan, a lawyer from Vancouver, fell in love with Bowen Island on his first trip in 1896. Several years later he bought his first property and continued to buy surrounding properties. By 1917, he had acquired over 1000 acres on the southeast corner of the Island that he named Point Cowan. He opened a store and other facilities to cater to the local population as well as visitors from Vancouver. Cowan loved farming and had the Japanese put in a vegetable farm on Seymour Bay that was a short distance up the coast from Point Cowan. ${ }^{30}$

In June 1922, my father bought 320 acres of timberland probably from George Cowan, with stands of Douglas fir and cedar at Point Cowan, at the southeast corner of Bowen Island. Lot 2448 bordered on Seymour Bay and the terrain appeared to be flat. He set up a camp for his employees and their families. Horses were employed to haul the logs over a skid road to a timber assembly area. There, the logs were loaded onto sleds that were pulled over a skid road to the storage area along the shore of Seymour Bay. The Douglas fir logs were sorted and formed into booms that were pulled to a sawmill or to a boat for export. Cedar shingle bolts were produced for the local market.

People from my father's logging camp patronized Cowan's enterprises and helped his cash flow. When Mrs. Woods, the wife of the Attorney-General for the province of Alberta, gave birth to her third baby, the Japanese wives from my father's camp trudged through the woods to visit her with their babies strapped on their backs. They were fascinated by the sounds from the windup gramophone. ${ }^{31}$

Hauling logs at Point Cowan on Bowen Island was completed in October 1924.

\section{Tokyo Earthquake}

30 Howard, 1973, pp. 16-17, 26-28, 36, 60-64.

31 Howard, pp. 60-66.
In Japan, on September 1, 1923, Tokyo was hit with a violent earthquake. A number of very severe shocks caused the land to roll in waves approximately six to eight feet high like a violent ocean. Tremors and small shocks were felt intermittently during the next 24 hours. As the hundreds of brick and stone 


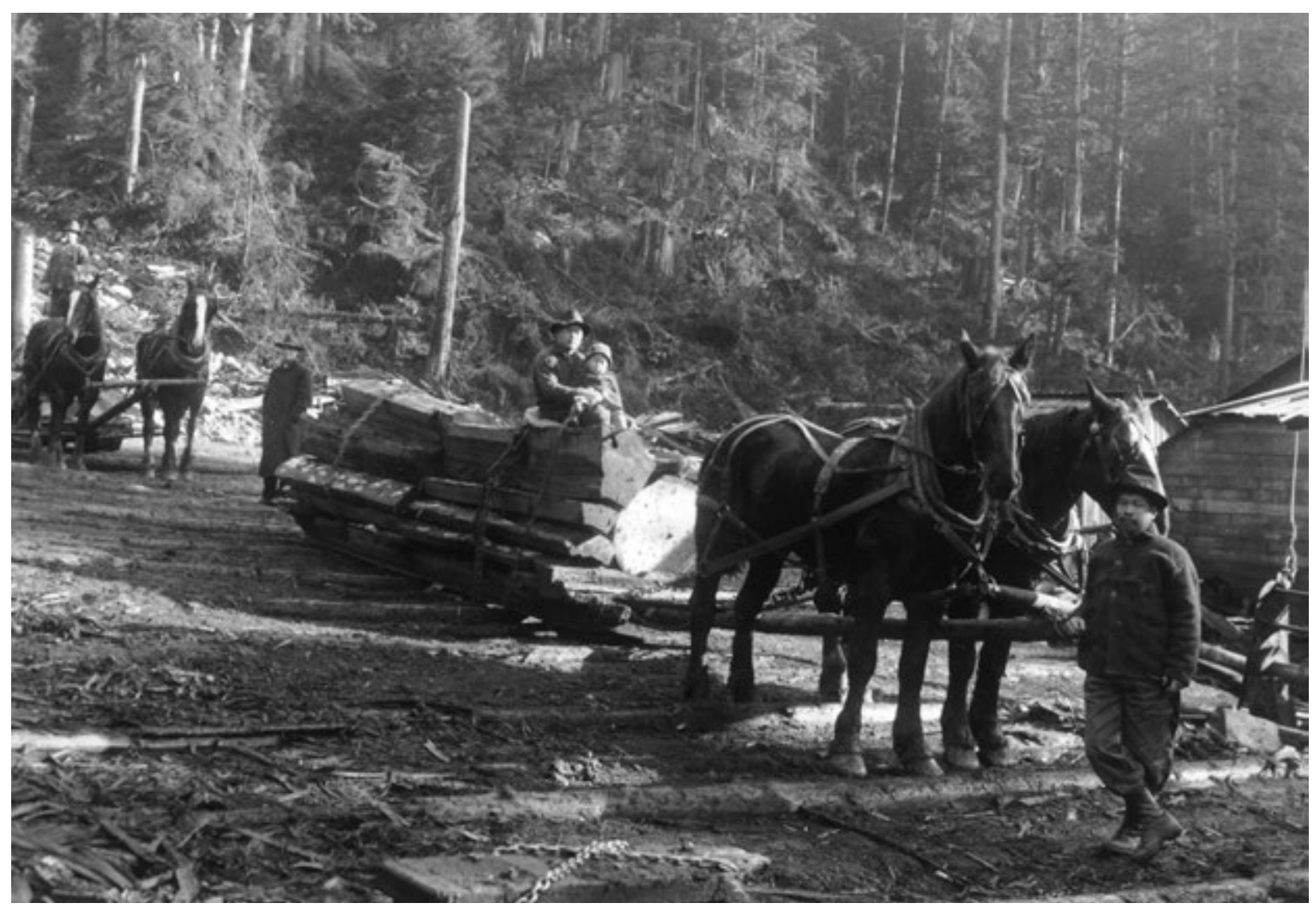

buildings collapsed, a dense cloud of dust rose up hundreds of feet. This was Eikichi with horses and sleds loaded quickly followed by heavy smoke as the wooden structures caught fire. ${ }^{32}$ My father recalled: ${ }^{33}$

After I began exporting, my greatest memory is about the Tokyo Earthquake in 1923. I had three ships fully loaded with timber. As the ships were approaching Yokohama, there was a severely heavy storm and I incurred heavy losses from all the damage. I felt if only I had been in Japan at the time.

32 Robinson, 1923, pp. 1-2.

33 Takahashi [Interview with Venerable Eikichi Kagetsu No. 1 Among Japanese Canadians], pp. 16-17. 
Four years earlier, after World War I, Montague Meyer and H. R. MacMillan formed the H. R. MacMillan Export Company Limited and became the first lumber exporting company in British Columbia. After the earthquake, Japanese authorities contacted the Canadian Trade Commissioner in Yokohama and ordered 40 million board feet of lumber needed for reconstruction. The Trade Commissioner returned to Canada immediately and during a stop over in Vancouver on his way to Ottawa, he gave the entire order for lumber to H. R. MacMillan.

MacMillan diverted two ships loaded with lumber to Yokohama and sawmills in British Columbia were given large orders. My father helped supply some of these sawmills with logs. However, by the start of 1924 it became evident that the Japanese authorities had overestimated their lumber requirements. ${ }^{34} \mathrm{My}$ father's recollections stated:

After the Kanto Earthquake, a large quantity of logs were exported to Japan. However, the Japanese Rehabilitation Bureau used lumber supplied by H. R. MacMillan and therefore I incurred a huge loss.

\section{Kagetsu \& Company}

Kagetsu \& Company was formed early on for the various logging operations. On November 27, 1918, my father went to Japan on the Empress of Japan to study what timber products were most in demand. He left Yokohama on the Chicago Maru and returned to Victoria on February 24, 1919. Jinshiro Nakayama wrote: ${ }^{35}$

President Eikichi Kagetsu knew the timber market in Japan thoroughly and was able to fill any kind of order. An example of an average monthly shipment in 1918 was as follows: cedar square logs 100,000 board feet; cedar split logs 50,000 board feet; cedar logs 150,000 board feet; hemlock 50,000 board feet; yellow cedar 100,000 board feet. Annual sales were: red cedar 50,000 board feet; Douglas fir square logs 150,00o board feet and Douglas fir boards 50,000 board feet. He also had a pulp mill that produced 50-100 tons of pulp daily.

The Company currently handles such imports as pearl but- 
The customers are all in the Vancouver area. However, there are many negotiations underway with the view to expanding to markets in Eastern parts. Kagetsu \& Company employs 20-40 men for timber logging, 8-12 men for saw-mill operations. (output was in excess of 20,000 board feet daily)

Kagetsu \& Company Limited was incorporated on November 30, 1921. All of my father's logging and importing businesses were incorporated into this company. The initial shareholders were Eikichi Kagetsu and Samuel A. Moore, my father's lawyer. "He bought an office at 127 Cordova St. East and employed smart young men like Tamaki and Takahashi for the business office." In 1923, Mr. Tomekichi Maikawa and Sensaburo Nakamura were added as shareholders. My father's Vancouver office was moved to 355 Princess Avenue. One of the men working in that office was Mr. Kiyozo Kazuta, who was succeeded by Henry Arikado in 1935. 


\section{CHAPTER 4}

\section{A Large-scale Logging Operation}

\section{Starting Deep Bay Logging Co. Ltd.}

Levitz, 1997, pp. 9-13. See also Olsen, 2004, pp. 35-36.

2 The major shareholders of Deep Bay Logging Company Limited were Eikichi Kagetsu and Kagetsu and Company Limited; Takata, 1983, pp. 81-85.

3 Drushka, 1992, pp. 33-36.
T he early development of Vancouver Island was largely due to logging activities. A little over 50 miles northwest of Nanaimo lies Deep Bay and Fanny Bay. A few large logging companies were operating in this area in the 1920's. ${ }^{1}$ In the early 1920's, my father purchased 885 acres of timberland at Deep Bay. In late 1922, he took a business trip to Japan to meet with potential customers and to evaluate the market for logs.

The prospects must have been very promising as he launched his largest logging venture, the Deep Bay Logging Co. (DBL) which was incorporated on August 5, 1922. ${ }^{2}$ In August 1923, my father bought 3,000 acres of prime forest land at Fanny Bay (Lot 88) for \$55,00o from the E\&N Railway Company (E\&N Railway) with whom he had established a friendly relationship over a period of time. (See map - Operations of Deep Bay Logging Co. Ltd., p. 28). The total capital investment was $\$ 200$,000.

My father had to develop a plan for cutting the trees and transporting them to water. This determined what equipment was needed initially to start operations and how many workers to hire. All logging operations used fallers who cut down the trees and buckers who cut off the branches and cut the logs into the length required for the final product. ${ }^{3}$ By 1923 , many companies were trans- 


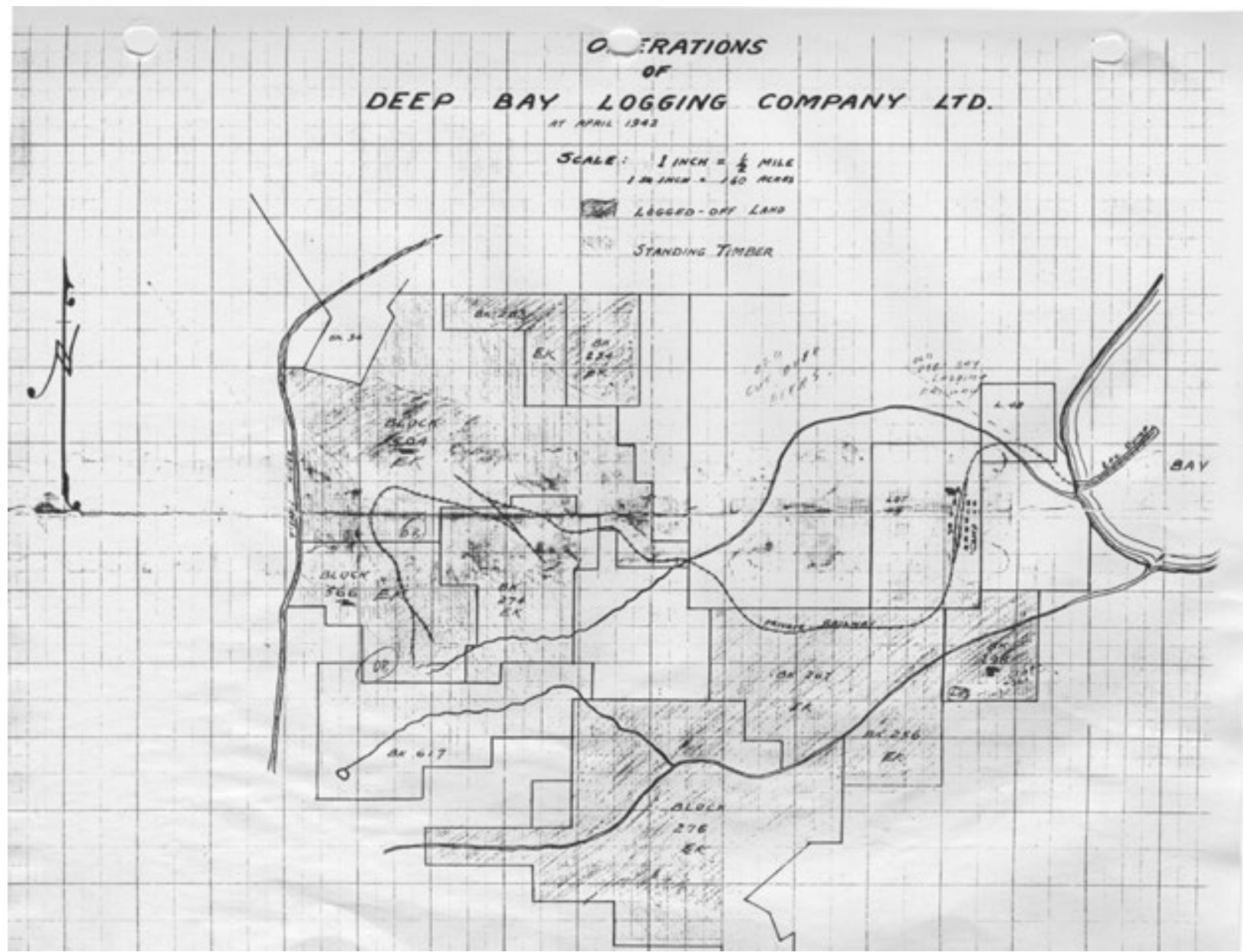

Operations of Deep Bay Logging Co.

porting logs by railway and my father decided that was the best system to use Ltd. on his large timber lands. ${ }^{4}$

Loggers used the term "yarding" to describe the operation by which the cut logs in the forest were moved to the railroad using steam-powered winches called "donkey engines" or "yarders." By the 1920's, the high lead yarding system was adopted by most logging companies because of its simplicity, low capital cost, ease of set-up, and small operating crew. This was the system selected 
5 Turner, p. 3. See also Tuomala, 1960, pp. 20-22; Drushka, 1992, pp. 109-111.

6 Gould, 1975, pp. 216-220. See also Gold, 1985.

7 Tyke Surgenor (Interview, September 6, 1998).

8 Isenor, Stephens, \& Watson, 1988, p. 32.

9 Levitz, pp. 31-33. by my father. Also, donkey engines were used to load the logs onto the flatcars. With steam power, the largest logs could be handled easily and efficiently. ${ }^{5}$ The high lead yarding system required a standing tree four or five feet in diameter, called the "spar tree," located near the railway. The high rigger cut the branches off the spar tree as he ascended it, cut the top off, and rigged it at the top with the main block or pulley and other blocks. The main line-wire rope-ran from the donkey engine through the main block and was attached to the log to be yarded so that the end of the log would be lifted and pulled easily to the spar tree. ${ }^{6}$ The use of these new systems required new logging skills and the loggers developed their own terminology for the new jobs.

The timberland to be logged initially was close to the water and the decision was made to dump the logs into Fanny Bay. The booming ground was located opposite the current Fanny Bay Inn. Once in the water, the logs were graded, sorted, and moved into booms that held logs of the same grade. ${ }^{7}$

The route for the railway was established and a $\$ 30,000$ Caterpillar was purchased to build the railway bed. The railway was built to standard gauge and did not have any steep grades. My father bought a gas locomotive-or in the logging vernacular - a gas locie, and flatcars at a cost of $\$ 22,000$. The rugged topography required the construction of bridges and trestles. Small crossings could be built using logs and timber. Contractors were hired to build the required trestles and log dump in Fanny Bay at a cost of \$10,000. A donkey engine needed for yarding and loading was purchased for $\$ 25,000$. The law prevented Japanese from operating steam-driven equipment; so Caucasians were hired to operate the locomotive and donkey engines.

Within a 10-mile radius of Fanny Bay, Japanese communities had developed in Cumberland, Union Bay, ${ }^{8}$ and Deep Bay. ${ }^{9}$ Thus, my father had a good labour pool of Japanese workers from which to recruit workers for the many jobs involved in a modern logging operation.

In the early days, logging camps were notoriously overcrowded and lacked basic amenities, such as windows, ventilation, and mattresses. Most of the logging camps had bunkhouses for single and married men, but no facilities for families. My father cared for the welfare of his employees. At the Fanny Bay camp, he constructed housing for the workers and their families-bunkhouses and a mess hall for single workers, and a building for meetings and recreationat a cost of $\$ 9,000$. 


\section{Logging Operations Before 1931}

Little is known concerning problems that might have developed during this initial phase. By March 1924, major hauling of Douglas fir and cedar logs was in progress. The gas locomotive with its relatively low power could not handle the increasing volume of logs. Therefore, a 25-ton coal-fired, steam-driven Climax locomotive, built for the logging industry, was purchased with flatcars to improve the efficiency of transporting logs. With the grades at Fanny Bay, the Climax could only haul three cars. ${ }^{10}$ My father also owned a sawmill that was located along the highway nearby.

During the next 17 years, H.R. MacMillan Export Company Limited (MacMillan Export) was a steady customer of the DBL. Much of the logs purchased from my father were exported to Japan. The DBL sold logs to the nearby Fanny Bay Shingle Mill owned by Mackie, Barnes and Horton, who exported much of their products to Asia. ${ }^{11}$ A local newspaper reported in April 1925: ${ }^{12}$

The ocean-going Japanese boat, Ayaha Maru, (in Fanny Bay), took on 2126 cedar clears cut in 13- and 16-foot lengths for interior decoration of houses in Japan. The logs will, of course, be manufactured in Japan. The economy with which lumber is used in Nippon can be gauged from the fact that the sawdust... will be used for the making of toys and a sort of pulp. The cedar is bought locally by Messrs. Mackie, Barnes and Horton, the clear sold to the Japanese and the remainder used for making shingles.

Beginning in 1924 and for the next 17 years, additional timber land was acquired adjacent to my father's original holdings in the Fanny Bay area (See map - Operations of Deep Bay Logging Co. Ltd., p. 28). He did his own surveying and "timber cruises," sampling small areas to estimate the quantity or volume of timber and the distribution of tree species. In this way, he knew what a reasonable price should be for the timber land he was going to purchase. My father commented:

In the forestry business, surveying the timber is the key, my attitude is the tree trunk can be my pillow while I go into the woods to survey the trees. ${ }^{13}$
10 Tyke Surgenor (Interview, September 6 1998); Green, 1992. "Climax 1251" was the designation for this locomotive.

11 Glover-Geidt, 1990, p. 47.

12 Comox Argus, April 2, 1925.

13 Shibayama, 1941b, p. 165. 
By 1925, production at the Fanny Bay logging operations had increased to 4 million board feet.

On July 14, 1926 at 2pm near spar tree number 6, a donkey engine caught fire. The fire, fanned by a strong west wind, spread rapidly. By $7 \mathrm{pm}$ it reached the camp which was completely destroyed within two hours. Everyone was evacuated to the beach. A local reporter described the situation as follows: ${ }^{14}$

Louis Magnone was driving the locomotive for the Japanese logging camp and that night he repeatedly drove his engine through the flames with the smoke so thick he could hardly see, until everyone was out of the danger zone and all their personal effects were brought out. One must admire such pluck. All the boys of the neighborhood worked like Trojans with trucks gathering up furniture etc. and taking it out of the path of the fire. Miss Swan picked up a twoweek old Japanese baby lying on a pile of bedding among the flying cinders and nearly suffocated in the smoke. Its mother was frantically trying to save her belongings.

In the intense heat of Monday, the fire appeared to have originated in the yarder of the Japanese company. Fanned by the wind, it spread like a ribbon of molten fire down the logging track of the company-to the beach. Along this track and in the path of the marching tongues of flame were many dwellings belonging to the Japanese employees of the company and also some houses of the shingle mill employees. All these along with all the equipment of the logging company were destroyed. With as much of their furniture as they could salvage the Japanese women and children, evicted by the flames, made for the wharf where they huddled with their belongings until refuge was found for them elsewhere. The Community Hall at Fanny Bay is being used to house many of the refugees.

Fortunately, no one was injured. During the evening many local residents came to console and help the displaced people. In the following days, all employees fought the stubborn fire. The fire caused extensive loss of property and equipment estimated at \$70,000. In those days, there was no fire insurance. On August 5, reconstruction began and three months later, logging operations resumed. All employees were kept on the payroll during this period.

The logging operation proceeded smoothly and production rose from a lit- 
During the next four years, four smaller properties were brought into production. The export business to Japan and to the USA was good during this period. In 1928, Japanese freight vessels entered Fanny Bay and logs were loaded directly from the booms. Arrangements were made for a pilot to board the ship and guide it into Fanny Bay. ${ }^{15}$ The vessels bound for Japan came to Fanny Bay frequently to pick up a load of logs. The captains would invite my father on board for dinner. On occasion, the residents of the Fanny Bay camp would hold a picnic for the ships' crew.

My father's younger brother, Tsurutaro, accompanied by his wife, Hide, arrived at Fanny Bay from Japan in November 1928. As the unofficial mayor, he ran the "camp." He operated the power generator and heavy equipment. He also ran the company store that was connected to their residence and sold work clothes, tobacco, canned goods, and non-perishable goods.

The Fanny Bay Shingle Company continued to buy cedar logs from the Deep Bay Logging Company. In the early 1930's, the Shingle Company was destroyed by fire, and was rebuilt and finally sold. It was renamed the Totem Pole Shingle Company and continued to buy cedar logs from my father. ${ }^{16}$

\section{Major Changes in Logging Operations}

By 1931, the timber lands serviced by the railroad were depleted. Logging operations were shut down to construct a new camp to the southeast that was completed in September 1932. Buildings associated with the logging operations included an office, a blacksmith's shop, a workshop, a powerhouse, a water tank for the locomotive, and a double garage on the highway.

Many miles of railroad had to be relocated to access the remaining timber holdings before hauling logs could be resumed. My Uncle Tsurutaro was the foreman of the section gang that laid the railway. He was responsible for the safe storage of explosives away from the camp and the blasting to remove stumps and rock in the way of the railway. He also operated the Caterpillar tractor to properly level the ground. Ties were placed on a gravel bed and were packed with more gravel. The track was laid and spikes made by Irizawa, the blacksmith, were driven into the ties to hold the rail in place. A bridge had to be built across Cherry Creek. Two hundred-foot long trees were cut and laid across the creek, cross members were placed on them, and then the rail tracks were laid.

Meanwhile, in Nanaimo, William "Bill” Surgenor, found out that my father was looking for someone to run his locomotive at Fanny Bay. ${ }^{17}$ After inter-
5 Kiyozo Kazuta (Interview, May 1, 1995)

16 Glover-Geidt, p. 47.

17 "Red" Robinson (Interview, September 21, 1998). Note: Gould, p. 95: The Hastings Sawmill Company was reputed to have used the first steam locomotive, "Old Curly," for hauling logs. This locomotive was originally used to build the Panama Canal and got its nickname from one of its engineers, William "Bill" Surgenor, who had "curly" hair. Old Curly is on display in Heritage Park in Burnaby. 
viewing him, my father hired Bill. Growing up, his sons, Tyke and Earl, took on a number of different jobs. Earl Surgenor later recalled: ${ }^{18}$

When I was young, I didn't appreciate what your dad did for me but when you look back on it and are older, you realize that he gave me a break. He gave me a job and I was the only white kid. He did that because my father was working for him. You just couldn't get a job anywhere.

Tyke and Earl both reiterated, "Your dad was good to me."

In 1932, logging started in Block 198 and during the following year, Block 276 opened (See map - Operations of Deep Bay Logging Co. Ltd., p. 28). These properties supplied logs until 1938. Sometime during this period, my father began a limited program of reforestation of the areas that had been logged out. ${ }^{19}$ Yamacho of Kobe was given exclusive rights in 1932 to sell logs in Japan for my father. MacMillan Export continued to place orders for logs with DBL. There were some sales to the USA and to local sawmills. The depression affected the logging business and sales lagged. My father considered the best interest of his employees and continued logging operations despite financial losses of about $\$ 10,000$ in 1932. During the Great Depression there were no jobs to be had and people were going hungry.

In November 1933, a 60-ton Shay locomotive and 20 flatcars were purchased to enable large-scale hauling of logs. ${ }^{20}$ It could handle six cars where the tracks were at a rather steep seven percent grade. There was one place where it could pull only three cars. The mainline was in good condition and had very little trouble. The side lines to the logged area, being temporary were not built as well. Tyke Surgenor recalled: ${ }^{21}$

18 Tyke and Earl Surgenor (Interviews, September 6, 1998; March 8, 2000).

19 Takahashi, 1995, [Interview with Venerable Eikichi Kagetsu], p. 17. See also Sato, 1969, p. 289.

20 Green, 1992. The new (second-hand) locomotive was designated "Shay 3163."

21 Tyke Surgenor (Interview, September 6, 1998).
We fired up starting at 5 a.m. when there was no fire in the firebox. In a typical day, we steamed up at 6:00 a.m. and worked a 10-hour day. We used to park the locie just outside our house. It was about 12 miles to the back end, the area being logged.

In those days, the locomotive engineer was also responsible for maintaining the locomotive. If something went wrong, he fixed it. When required, he pulled the steam-tubes and replaced them. Repair parts were often improvised because it could take a month to get a spare part. 
My father used to call Tyke "Smokey" because he made so much smoke when burning wood or coal in the locomotive. Tyke wrote:
When I was a boy of seventeen
It was my introduction to steam.
The first was a Climax then a Shay
One was coal-next one wood. I must say
The Climax was small and pretty rough,
The Shay was smooth and plenty tough.
Hauled the logs down the hills to the chuck
Into the bull pen they float like a duck.
Then head back to the woods at fast pace
Which would bring a smile to Kagetsu's face.
My memories of that camp are still clear,
I'll never forget those days never fear.

Yoshio Murakami remembers his working day as follows: ${ }^{22}$

After breakfast around 7:30 a.m., we were transported on a speeder that carried as many as 20 workers to the work site. Generally, the workers started at 8:00 a.m. and quit at 5:00 p.m. Lunches for the single Japanese men were provided by the cook in round, aluminum lunch boxes that had two compartments. Rice was placed in the bottom compartment and the okazu (side dish) was placed in the top compartment. Those working near a donkey engine, could warm their lunch on the boiler.

In 1934, the market rebounded and prices increased. A record production of close to sixteen million board feet was achieved. To keep up with demand, a neighbouring logging company owned by Louis Tansky was contracted to haul logs out of Block 276 by truck on an existing road. The 25-ton Climax locomotive was sold at the end of March.

The winter of 1935 was characterized by heavy snowfall. Even in March, the snow had not melted sufficiently and operations were slow until early April. On Friday, June 7, work was halted at 10:30am due to strong winds. Despite this precaution, fire broke out from the Empire donkey engine at about $3 \mathrm{pm}$. Fanned by the high winds, the fire spread rapidly. Tyke Surgenor who was on the locomotive recalled: ${ }^{23}$
22 Yoshio Murakami (Interview, September 15, 1998).

23 Tyke Surgenor (Interview, September 6, 1998). 


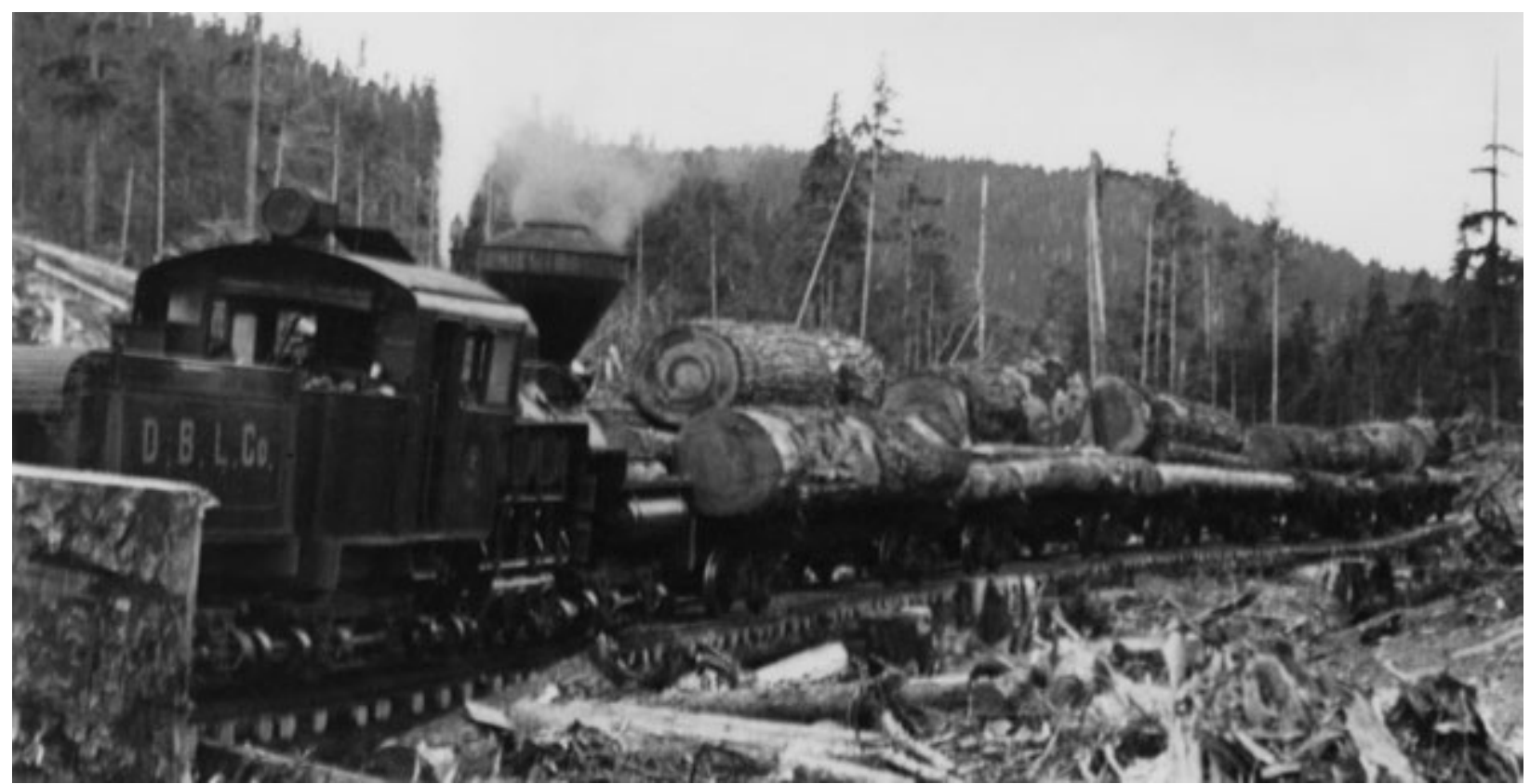

Train hauling logs at Fanny Bay.

I spotted the fire up at Coal Creek from the booming ground. So we headed back and we couldn't contain it. There was a diesel/gas dump that caught on fire. We had to get out of there because the gas drums were flying all over the place. There was a bridge across a cut and we filled the water tank up with water. We wondered if we could get back across that bridge because the flames were coming up both sides. There was no other way out and so we had to ride the locie through it. I tell you it was really scary. We covered ourselves with wet gunny sacks and lay on the floor. The paint was all burnt off the locie. It was a good thing that it was only a short bridge about a 100 feet long. We couldn't touch the cab of the locie because it was so hot. That fire was so severe and it is hard to breathe, the fire burnt out the bottom of the water tank.

My uncle's family recalls that everyone was packed and ready to evacuate because the fire was all around the camp. It was frightening. A local newspaper reported: ${ }^{24}$ 


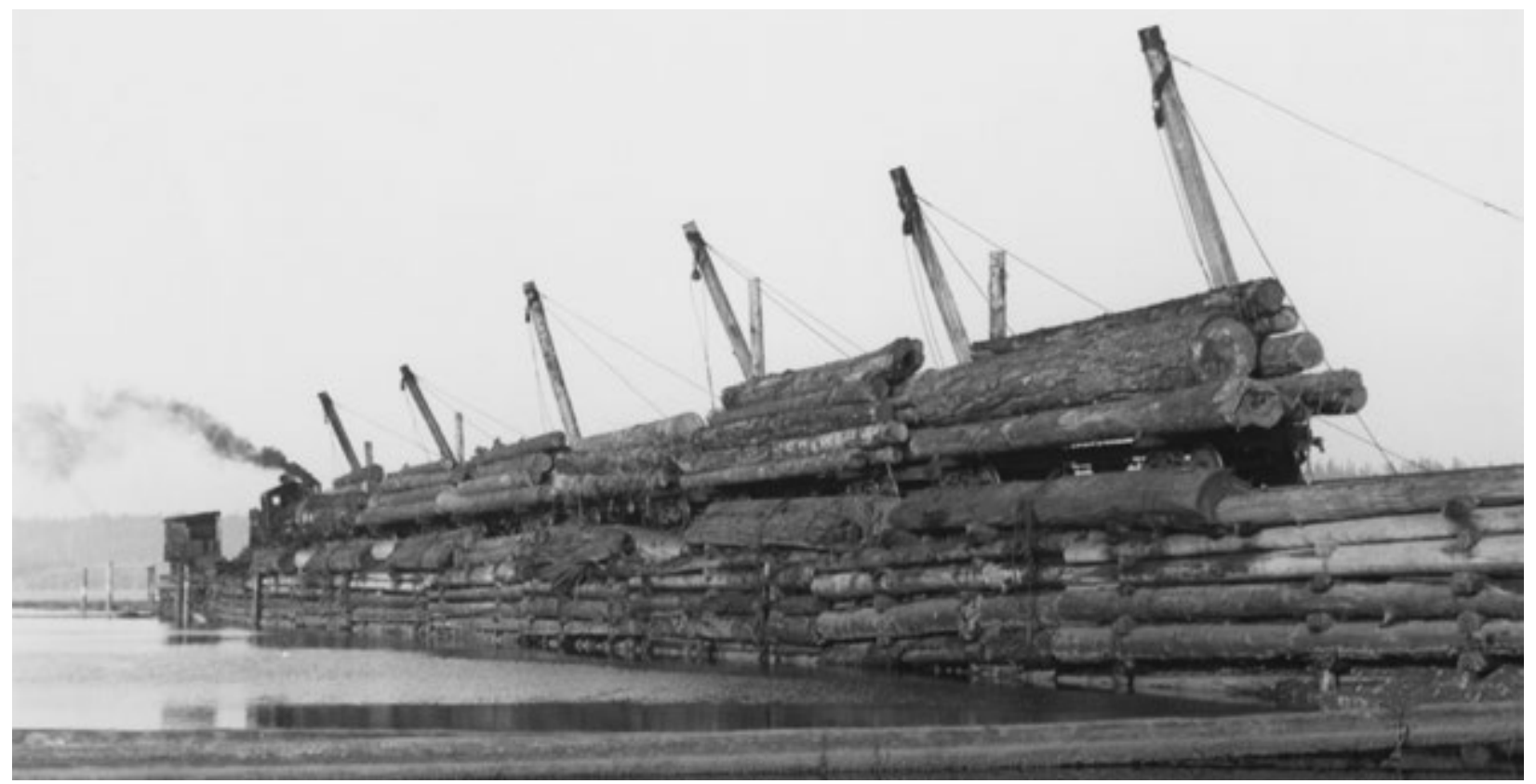

... billowing clouds of smoke which came down to the water and formed a fog-like screen could be plainly discerned from Courtenay and Comox Friday evening.

During the weekend, rumors persisted that some 12 Log Dump at Fanny Bay where logs off Nipponese loggers had been trapped by the flames and burned to death. This was proved untrue when the missing men later came out of the woods where the smoke and heat prevented their earlier appearance.

My father received a phone call at home that evening. My sister recalls that she had never seen him so dejected. His head dropped and a deep sigh was heard as he hung up the phone. He then related the bad news to the family. In that 1935 fire, five million board feet of felled and bucked whole logs, a donkey engine, several flatcars, bridges, and railroad ties were destroyed resulting in a huge loss of $\$ 58,000$. Reconstruction began immediately. A new Cle tractor was purchased in August for rebuilding the railroad. It took four months of rebuilding before logging operations could resume on October 7. 


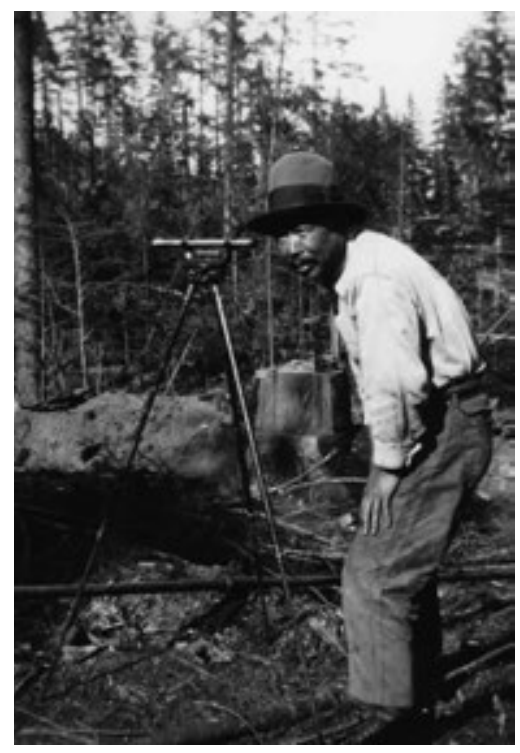

Eikichi surveying timber holdings at Fanny Bay.

25 J. M. Stewart, Inspecting Engineer (Letter to G. P. Napier, Esq. Deputy Minister and Chief Engineer,

Department of Railways, September 24, 1940).

26 Tyke Surgenor (Interview, September 6 1998).
Between 1936 and 1939, the market for logs was good for the first two years and then turned poor. Weather played a major role in the logging operations at Fanny Bay. During the winter of 1936-37, work stopped for three months because of snow up to 2.5 feet deep, the most my father had ever seen. The following winter, rain melted most of the 2 feet of snow and the muddy conditions impeded logging operations. In the summer of 1938, lack of rain caused a severe fire hazard and logging operations were stopped for three months. At year-end, heavy rains damaged part of the railroad and required costly repairs. Heavy rains in June 1939 permitted logging operations to resume for part of the summer, but at the end of July, logging ceased due to a long spell of dry weather. During this period, when logging at one property was completed, another was opened up. Extra part time Japanese workers were hired during the summer.

Sometime after the outbreak of World War II in September 1939, an embargo was placed against Japan, which included the shipment of logs. Marketing efforts were shifted to Canadian and American sawmills. In January 1940, work began due to good weather. An engineer from the British Columbia Department of Railways inspected the railway and recommended that parts of the railway have ballast added, and that the bridge across Cougar Creek, (Bridge No. 1), and the log dump trestle be strengthened with fill. Log hauling was suspended for approximately one month until this work was completed on September $16 .{ }^{25}$ Log production in 1940 was a little over 10 million board feet-a little higher than in 1939.

Operations during the first half of 1941 were normal. Workers at Fanny Bay completed the construction of a new branch line, and hauling from the new area started on August 25. The market for logs suddenly improved during the second half of the season. My father took Akira and myself to Fanny Bay in July 1941. We accompanied him as he inspected the working areas and watched the loggers at work. One area we observed was described as follows: ${ }^{26}$

One area along the Creek was covered with huge beautiful Douglas fir trees. They hauled 18 loads a day from that area for about 6 weeks or two months and every one of them was a three-log load. One of the best booms along the coast came out of there. He (my father) used to boast about that.

The overall business was good during 1941.

My brother, Hajime, was studying Forestry Engineering at UBC. In his thesis titled "Motor Trucks as Feeders to Railroads," he discussed the advantages and disadvantages of using trucks to haul logs to flatcars on railroads, as he 


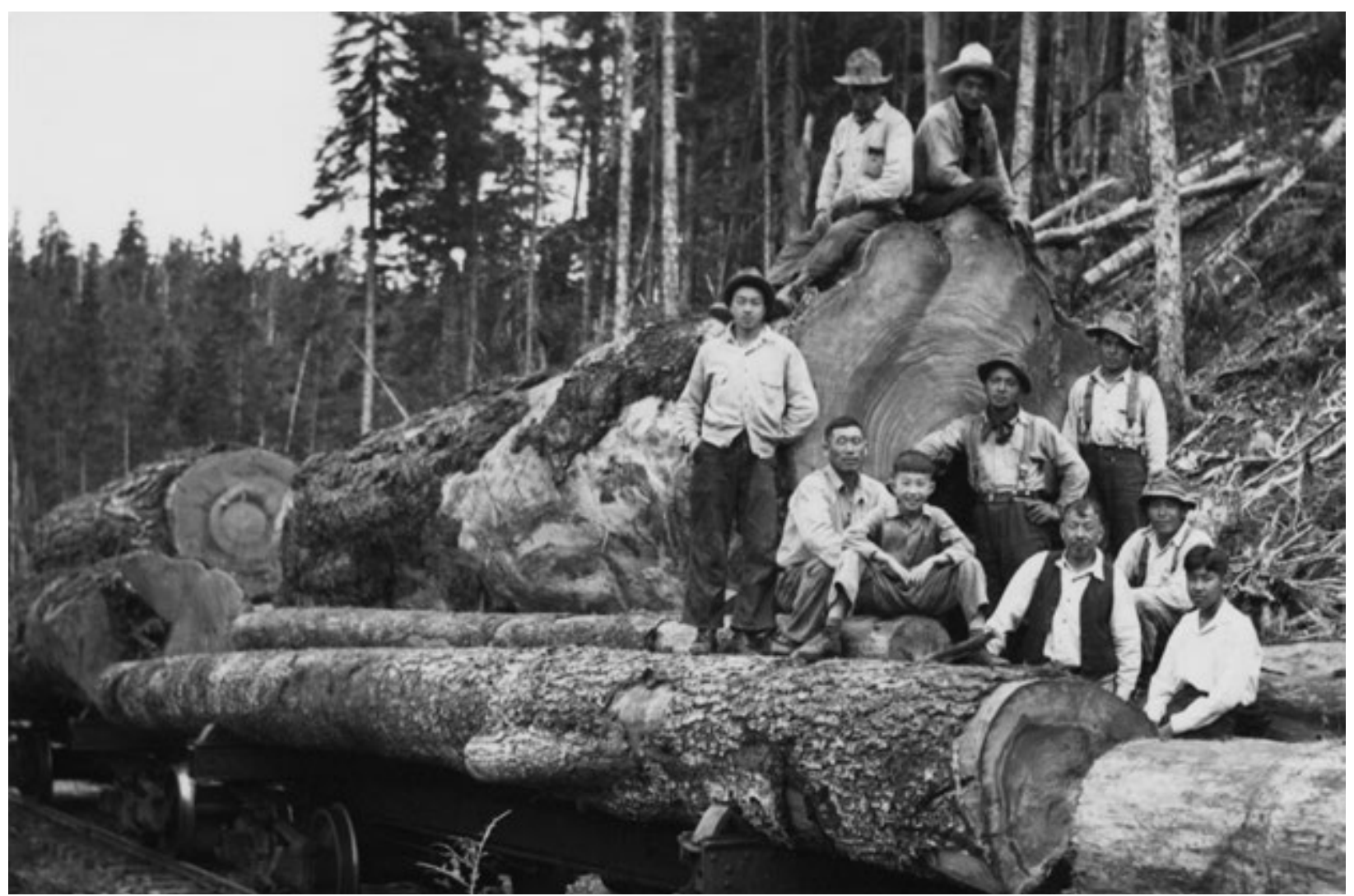

must have believed that would be the future trend at the Fanny Bay camp. ${ }^{27}$ My father was looking forward to Hajime's graduation and having his help with his logging operations. He had an office built for him at the Fanny Bay Camp in anticipation of his graduation.

The DBL was poised to supply the needs of the expanding war effort. The standing timber was adequate for many years of production. An efficient railway transportation system was in place. Over the years, other equipment had been purchased as required. However, the full potential of this logging operation was not to be realized.
Eikichi with workers and sons Akira (right) and Tadashi (left) on a railcar loaded with a giant log at Fanny Bay.

27 Kagetsu, 1942 


\section{CHAPTER 5}

\section{Life in a Logging Camp}

\section{New Camp}

$\mathrm{T}$

he "new" camp, built in 1932, was about a mile along the tracks that ran southwest from the log dump and highway. There was a hill leading up to the town. The first buildings were houses and a bunkhouse for the Caucasian workers. By the spring of 1942, there were 10 bunkhouses and a total of 23 homes including those close to the highway and to the log dump. There was a platform alongside the highway where groceries and food for the camp were loaded and a double garage. ${ }^{1}$ A former resident of the camp, Yoshio Murai described it as follows: ${ }^{2}$

1 Tyke Surgenor (Interview, September 6, 1998).

2 Yoshio Murai (Interview, June 4, 2000).
There were bunkhouses which housed 4 single men each. There was one cookhouse and one bathhouse for them. There were single-family homes in the camp and a few down by the highway. They had their own Japanese-style baths made of wood on the sides, with a metal bottom and heated with a fire underneath. Many people had big families and so the house had 4 or 5 rooms. The outside walls were cedar shakes and the inside was papered to keep the wind out. A few homes, including ours, had running water from Cougar Creek. Others had wells. Trout were put in the well to eat the bugs, etc. and keep the sides of the well clean. Everyone had an outhouse. 
The generator was located near your uncle's (Tsurutaro Kagetsu) house. It provided electricity to the bunkhouses and the cookhouse but most family homes had no electricity. We used kerosene lamps for light. At a certain time at night, the power was turned off by your uncle.

Bill Surgenor's grandson, William Robinson, recalled: ${ }^{3}$

My grandmother (Bill Surgenor's wife) thought it was one of the nicest little towns. It had a lot of fruit trees and everybody had a garden, not just vegetables but trees and shrubs. My grandmother did not like Chinese food but liked Japanese food. That tells you something right there. However not the octopus, she never got used to that!

\section{Another grandson, "Red" Robinson related: ${ }^{4}$}

My grandfather and his daughter, Alice, would visit a Japanese family. She said that the Japanese were so clean that you could eat off the floor. They scrubbed them every day. As I grew older, I realize how important cleanliness was to the Japanese culture.

My father loved gardening so he had a miniature Japanese garden built with many colourful flowers, with water flowing under a little bridge, and with a 5foot Japanese stone lantern.

\section{Fanny Bay School}

The children at the Fanny Bay camp walked about a mile along the tracks to the highway and south along the highway for about another mile to the school. Fanny Bay School was two stories high and had a basement. There was a big oil barrel stove and wood was stored in the basement.

Division 1, which included grades 5 through 8, was upstairs and Division 2, which included grades 1 through 4 , was downstairs. There were two teachers, one for each division, and the Division 1 teacher was also the principal. One of the teachers was Miss Margaret McNaughton who became the principal. Other teachers remembered by the Fanny Bay students were Miss Jorga Eek

3 William Robinson (Interview, September 22, 1998).

4 Red Robinson (Interview, September 21, 1998). 


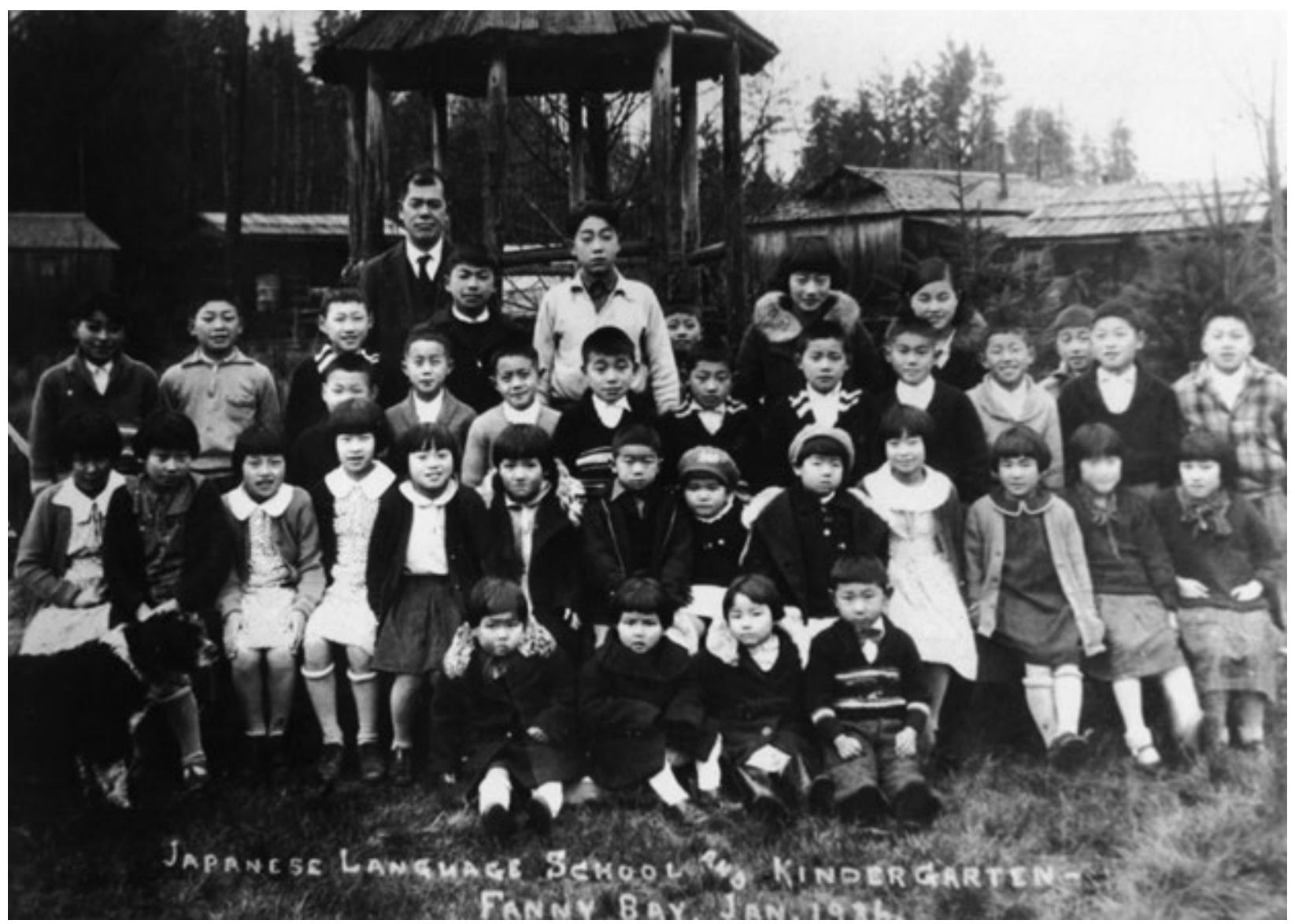

Fanny Bay Japanese Language School and Kindergarten students with language teacher, Mr. Jiro Kumagai.

and Miss Vi Chungranes. The enrolment was over 70. Margaret McNaughton Egger recalled the following about my father: ${ }^{5}$

He used to come around once in a while and knock on the door of the school. He would not come in but would talk outside so that he would not disturb the students. He was always well-dressed and wore a hat most of the time. He was kindhearted, very polite, very

5 Margaret McNaughton Egger (Interview, September 7, 1998). 
to give Susumu (my cousin) a note which he took home to his papa (my uncle Tsurutaro).

Miss NcNaughton and Miss Eek, together with teachers from the Hornby Island and Denman Island schools, initiated a Tri-Schools Track Meet on Denman Island. My uncle provided trucks to carry the participants to Deep Bay where they were transported across Baynes Sound on a ferry. The men ran the races and the ladies took care of the ice cream and lemonade. At the end of the day, they were met at Deep Bay and transported back to the school on the same trucks. ${ }^{6}$

The Fanny Bay camp provided transportation when the students went to Courtenay to see a movie. Margaret McNaughton commented, "They couldn't have been more cooperative." Margaret McNaughton found that the Japanese were generally very good students and well behaved. In fact she had little trouble with all the students. The students considered her a good teacher and liked her. A number of Japanese students remembered that Miss McNaughton and Miss Eek were good to them.

My cousins recalled that when they went to Fanny Bay School, they took a rice ball for lunch and ate apart from the Caucasian students.

Miss Eek taught her students dancing and acrobatics. My cousins Natsuko and Yoshiko Kagetsu were on the acrobatic team and did tumbling. They made a human pyramid and Yoshiko, being the smallest, was on top. The school had no gym equipment. Every year, the students, teachers, and parents put on a Christmas concert. In 1939, the older Japanese girls staged an authentic Japanese dance and song taught by Mrs. Gyoba. Yoshiko Kagetsu was the youngest and had to lead the dancers wearing kimonos onto the stage. ${ }^{7}$

\section{Community Halls}

When my father had a new Community Hall built at the Fanny Bay camp, a group from the camp put on a Japanese play about samurai-Ieyasu Tokugawa, a shogun. ${ }^{8}$

As the children of employees were growing up, my father organized a kindergarten in the Community Hall. Alice Surgenor, Bill Surgenor's daughter, and Edna Robertson were volunteer teachers. Japanese children were taught how to make and sound their letters. This was helpful when they started the regular school at Fanny Bay because they spoke Japanese at home. When Alice Surgenor

6 Isenor, 1980, p. 95.

7 Hide Kagetsu \& Family (Interview, September 30, 1998).

8 Yoshio Murakami (Interview, September 5, 1998). 
9 Georgina Surgenor (Interview, March 8, 2000).

10 Yoshio Murai (Interview, June 4, 2000).

11 Margaret McNaughton Egger (Interview, September 7, 1998)

12 Olsen, 2004, pp. 89-91. got married, Georgina Curran, who later married Earl Surgenor, volunteered a couple of hours every morning. She had to walk five miles to the camp. ${ }^{9}$

The Japanese School held in the Community Hall at Fanny Bay went up to grade 8 and was taught by Mr. Kumagai. About 20 students attended from $4 \mathrm{pm}$ to $6 \mathrm{pm}$ every day and also for a couple of hours on Saturday mornings.

The Community Hall was quite big; most of the camp came to watch Japanese movies shown by Mr. Tsuyuki. They had to take the generator from the locomotive because the camp generator was not powerful enough. There may have been about 70 (50 adults) people at the Camp. ${ }^{10}$ Margaret McNaughton Egger recalled: ${ }^{11}$

It was a special occasion when they showed a Japanese movie at the Fanny Bay camp. I walked to the railway and Bill Surgenor would take me up to the camp on the locomotive. If the movie was in Japanese, one of the older girls would be the interpreter. Sometimes they would be fighting the Chinese in the movie. If the Japanese were winning, they would all shout banzai. They also had English movies. Mr. Kagetsu was a very progressive man. Anything he could do to make life better for the inhabitants at the camp, he would do it.

My father took movies of the logging operations at different locations. He showed them on Saturday night with movie shorts such as cartoons or other topics that he purchased from Kodak. He got a good laugh from the audience when he showed some workers loafing or doing other things they shouldn't have been doing.

The Isseis had a social group called the Kyoei Kai that met at the Community Hall. They drank tea, played cards, sang, etc. The Niseis played card games such as whist and cribbage. Weddings and funerals were also held in the building.

In 1931, the Caucasian community around Fanny Bay decided to build a Community Hall using land, materials, and funds donated by local citizens and companies. Eikichi Kagetsu donated \$250 and promised additional funds from his employees. At the Fanny Bay Athletic and Social Society's first annual meeting, Abe McLauchlin was named honorary president and Eikichi Kagetsu honorary Vice-President. The Community Hall was used for a wide variety of activities including sports, whist, bingo, dances, movies, wedding receptions, Christmas concerts, meetings, etc. ${ }^{12}$ 


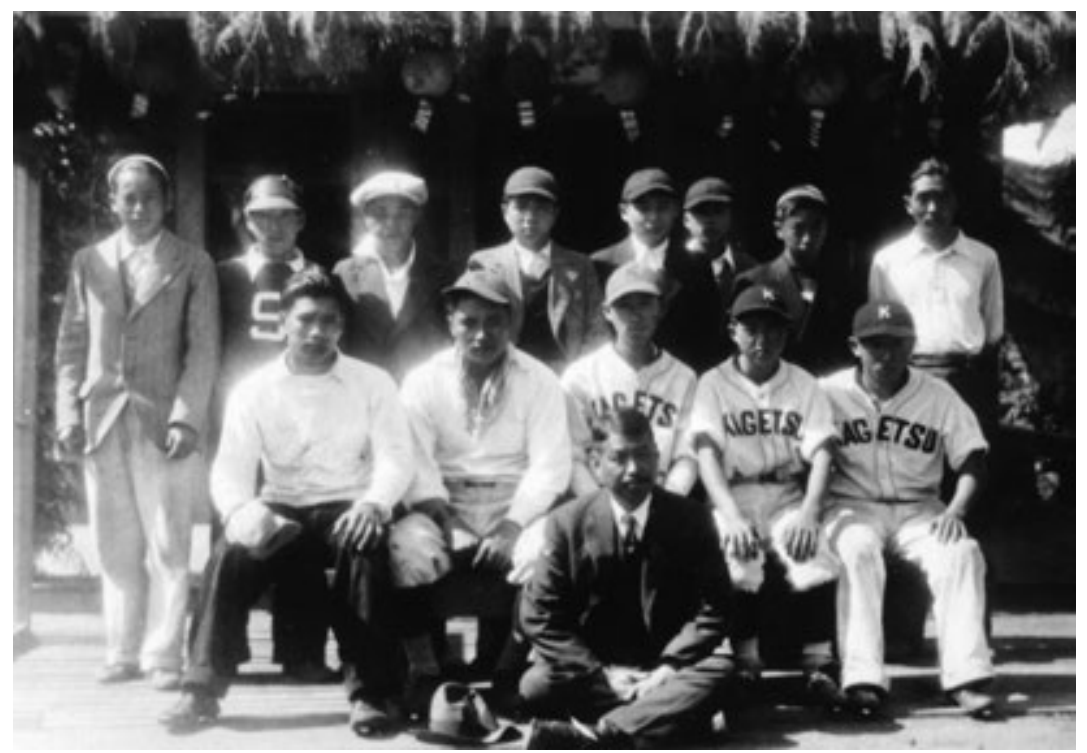

\section{Recreation}

In 1931, my father decided to put together a company baseball team and built a baseball field at the camp. He hired Ken Nakanishi, who was the pitcher for the Asahi baseball team when they won the Terminal League Championship two years later in $1933 .{ }^{13}$ Tyke Surgenor, who was the only Caucasian to play on the team, recalled: ${ }^{14}$

I played with the Kagetsu baseball team just after I came to Fanny Bay. I was a good baseball player when I was young. I played first base, in the field, pitcher or any other position. I remember the Tshirt with Kagetsu across the front. We played Cumberland that also had a Japanese team. The Kagetsu team was a good team. We played more than one summer. They built that field near Fanny Bay Hall and practiced there. Then they built a field up in the camp and practiced there. They had a Japanese coach who may have worked at the camp.
Kagetsu Baseball Team at Fanny Bay Camp.
13 Adachi, Pat, Asahi, A Legend in Baseball (Etobicoke: Asahi Baseball Organization, 1992), p. 85.

14 Tyke Surgenor (Interview, September 6, 1988). 
15 Courtney Free Press, June 2, 1931; Cumberland Islander, June 5, 1931; Cumberland Islander, June 12, 1931.

16 Tyke Surgenor (Interview, September 6, 1998).

17 Hide Kagetsu \& Family (Interview, September 30, 1998).

18 Hide Kagetsu \& Family (Interview, September 30, 1998).
A local newspaper reported on an exhibition game between the newly formed Fanny Bay team and the Cumberland Athletics. The latter won by a score of 11 runs to o. A week later, the Royals and Fanny Bay tangled "in a friendly game which proved to be an exciting one. A large number of spectators enjoyed the game won by the Royals, 15 to $12 .{ }^{15}$ Tyke Surgenor recalled: ${ }^{16}$

When I was a kid, I owned a car even though I only made 29 cents per hour as a brakeman on the locie. I knew Kagetsu had a gas barrel in his car which was a Dodge Gray Door. I climbed over the wall and took some gas. I had no sooner got the gas when he caught me red-handed. I thought I was going to get fired. He never did a thing to me. He said "You know you don't have to steal gas. There is plenty of gas up on the loading platform in the camp." In those days gas cost 15 cents a gallon. I could have gotten all the gas I needed up there but I was in a hurry. I guess he felt sorry for me.

For entertainment, the young people went swimming, fishing, and played baseball, and other games. The children were pretty well stuck in the camp area. Nobody had a bicycle. My cousins recalled: ${ }^{17}$

We caught rainbow trout in the creeks. We caught shiners from the government wharf in Fanny Bay. We either ate the shiners or used them for bait to catch perch. We dug for clams and oysters.

The older boys and men would play the boom man's game. Two men stood on a log in the water and spun logs with their feet to dislodge the other. The men went hunting. You could see the tracks of cougar in the snow around the camp in the wintertime. There were black bears, wolves, and other animals in the area. My father liked to hunt at Fanny Bay. In our living room in Vancouver, there was a full-sized cougar on a simulated mountain side. We had a cougar throw rug with the full head that ferociously showed the teeth and a black bear throw rug preserved in a similar manner. Over the years, my father had countless numbers of cougar rugs made. Every time a VIP guest visited him, my father would give a cougar rug as a souvenir gift. 


\section{Food}

The adults went up into the mountains to look for matsutake, a delicious mushroom. Once, Tsurusan took a group to search for matsutake on the way home from work. The matsutake were found by scratching away the needles at the base of a fir tree. They were late coming home and it turns out that they got lost.

Groceries were ordered from the Maikawa Fish Store in Vancouver and were delivered on Thursdays on a scow boat. Dry goods including clothes were ordered from the Maikawa Dry Goods Store. The camp residents were able to get almost everything they needed from the Maikawas, who were good friends of my father. ${ }^{18}$

On New Year's day, the women would be too busy cooking and couldn't go out. For New Years, in every home, the Issei women used to make a lot of delicious food. They had delicacies such as octopus, sashimi, and sushi. Mr. Tsuru made mochi (rice cake) using a large wooden mallet to pound the glutinous rice while a second man kept turning the mass over and over. Pieces of this sticky, gelatinous mass were formed into round cakes of varying sizes. For New Year's Day they made kagami-that consisted of a large mochi on the bottom, a smaller mochi on top of that and a Japanese orange (tangerine) on the very top. These were placed on the locies, speeders, donkey engines, etc., for good luck during the coming year.

The men used to make the rounds of the homes. They had gatherings at the Japanese School and listened to speeches. The Caucasian workers were invited to the Japanese homes and treated to the Japanese New Year's spread.

\section{Oyster Beds}

The owners of the Japanese Logging Company at Fanny Bay are credited as being the first to introduce oysters into the (Baynes Sound) area. ${ }^{19}$ My father's good friend, Mr. Sannosuke Maikawa, who owned the Maikawa Fish Market in Vancouver, had friends in Bellingham, Washington where they grew oysters. He suggested to my father that they should try to grow oysters in Fanny Bay. After testing the water, they ordered nine crates of oyster seeds from Japan. The seeds were attached to string or shells. The box was placed on the bow of the ship so that the spray kept them wet. ${ }^{20}$
19 Janette Glover-Geidt (Letter to Jack Kagetsu, August 6, 1998); Krause, 1997, p. 75; Olsen, pp. 35-36.

20 Sadao Maikawa (Interview, November 2, 1999). 
21 Glover-Geidt, 1990, p. 56

22 Sadao Maikawa (Interview, November 2, 1999)

23 Tyke Surgenor (Interview, September 6, 1998).

24 Glen Hadden (Interview, September 8, 1998,); Globe and Mail, November 26, 1993.
Jack Anderson, a former employee at my father's logging camp at Fanny Bay recalled: ${ }^{21}$

About 1926 or '27, Louis Magnone was running the locie and my Dad was firing at the Jap(anese) Camp in Fanny Bay. The owners brought in nine crates of oyster seed from Japan, and the train crew took them down to the beach.

Mr. Maikawa went to Fanny Bay every year to tend the oyster beds. He lived in a boathouse and had to cart water for drinking and washing from a well. His son, Sadao, helped his father work on the oyster beds. He remembered showing a health inspector from Victoria where the oyster bed was located so that he could check the quality of the water. ${ }^{22}$ The oysters took about three or four years to grow. The work schedule on the oyster beds depended on the tide. Clusters of small oysters had to be broken up. They were harvested with a rake at low tide.

Because of the slow growth, additional oyster seeds were ordered from Japan around 1931. Tyke Surgenor helped to load the 8 feet by 4 feet boxes containing the oyster seeds onto the flatcar. The seeds were on bamboo sticks. ${ }^{23}$ With the additional oyster beds, my father got permission from the E\&N Railway to use about 10 acres along the shore to carry out an experiment in oyster culture. If the production of oysters was a success, my father planned to incorporate a company and lease the foreshore. The production of oysters at Fanny Bay was insufficient to support a business. Surplus oysters from the local consumption were sold at the Maikawa Fish Market in Vancouver market for $\$ 1.00$ per gallon.

When the technology for producing large quantities of oysters was developed in the 1980's, an oyster growing industry grew up around Fanny Bay. Currently, Fanny Bay Oyster Company ships oysters that are served at fine restaurants around the world. ${ }^{24}$ 
TREE TRUNK - MY PILLOW I KAGETSU 


\section{CHAPTER 6}

\section{An Unwanted Partnership}

\section{Joint Venture with Mitsui Bussan}

1 Kodansha, 1983, Vol. 8, p. 261

2 The forest wealth in the Cowichan Lake area was known for a long time. See Saywell, 1967, pp. 27-34; Rajala, 1987, pp. 10-11.

3 C. M. Stewart (Letter to G. W. McPherson, September 28, 1942). n Japan, zaibatsu is an industrial and financial conglomerate of companies resting on a common ownership base and operated as a unit. Mitsui \&

Company Limited (Mitsui) is one of the big four zaibatsus in Japan. ${ }^{1}$ Mitsui was a good customer for my father's logging company. They wanted logs for Japan and decided to go into the logging business in Canada. In 1936, they started negotiations with my father, knowing that he was one of the most successful Japanese logging operators in Canada. My father recalled: ${ }^{2}$

At year-end Mitsui proposed a joint venture near Cowichan Lake where there were 5,000 acres of timberland. This will entail more hard work and more headaches but probably this has to be done.

The partnership was formed in 1937 and was named Ocean Timber Company Limited (Ocean Timber). Initially my father supplied \$25,000 and Mitsui invested \$75,000. Subsequently, Mitsui loaned the organization \$255,000. At that time, my father was given a letter signed by the Mitsui manager in Seattle, which stated that his losses in no event, would exceed \$25,000. ${ }^{3}$ My father was the manager and Mr. Yoshikane Shimazaki, Mitsui's timber expert from Japan, was the 


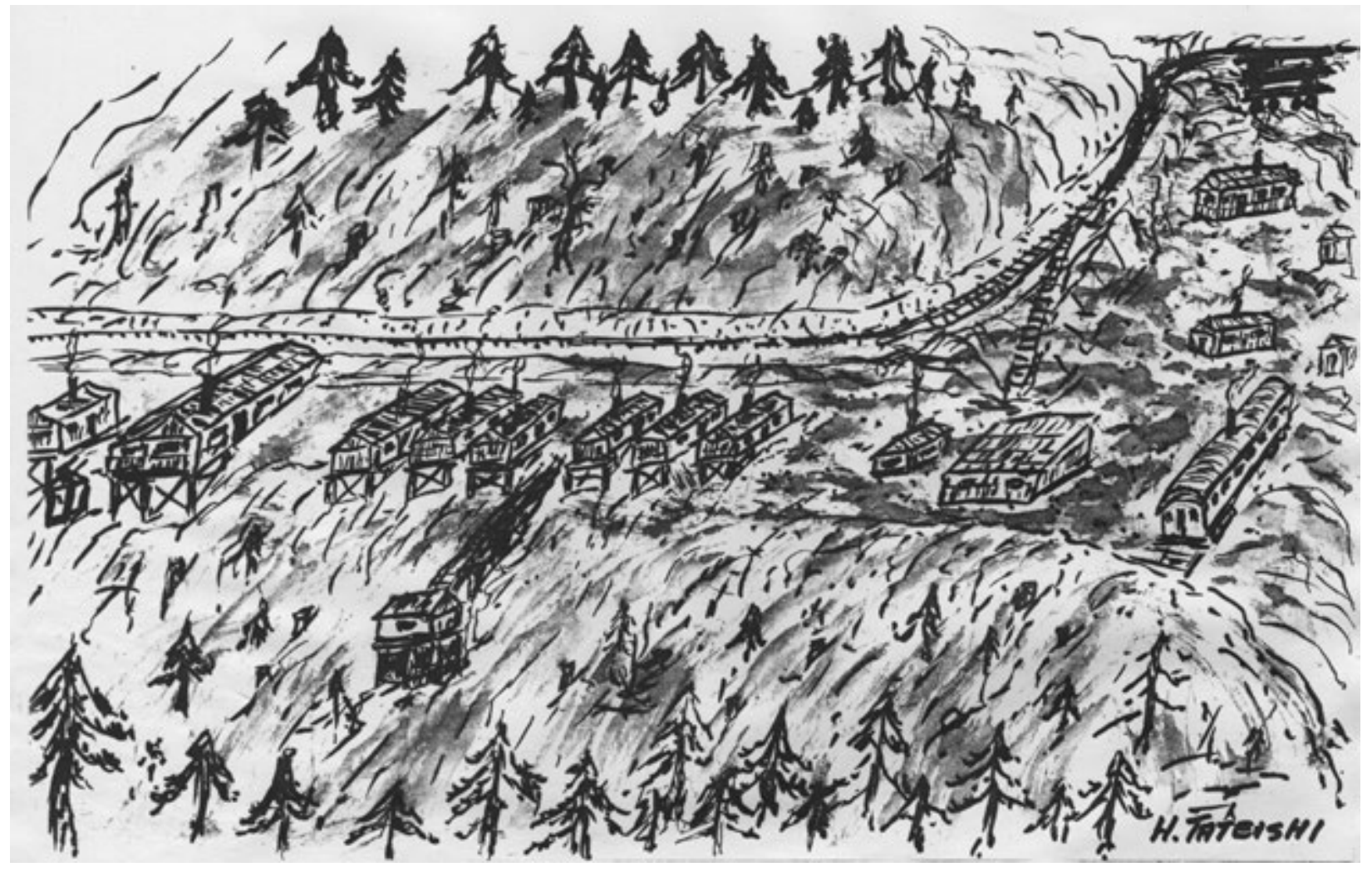

superintendent of the Ocean Timber operations at Cowichan Lake. Mr. Shimazaki came to Canada with his wife and son, Yoshihiko, who became a good friend of mine. My father bought a house for them two doors down from our home in Vancouver and had a Japanese-style rock garden built with flowing water, a fountain, and a pond for fish.

The purchase of timberland known as Lot 66 and B403 at Lake Cowichan by Kagetsu \& Company was finalized on April 30, 1937 and later, these properties were transferred to Ocean Timber. At a later date, the company intended to acquire an adjoining block of timber land known as Block 195, which was owned by the E\&N Railway. My father stated:
Sketch of Ocean Timber Camp at Cowichan Lake by Henry Tateishi. 
Since I am going to do the logging myself, I conducted a very thorough survey. There is definitely about 50,000,000 (board feet) and many smaller trees.

On May 10, 1938, my father wrote to the Mitsui manager in Seattle informing him that the railway company had advised him that another company wanted to buy Block 195. My father stated in his letter that it would make a great change in their original plans and that he intended to buy the land in question on his own account. On May 12, the Seattle manager confirmed that they wanted my father to purchase the timber land before someone else bought it.

Newspapers reported these purchases of timber land being made by Kagetsu \& Co. and exaggerated the yield. ${ }^{4}$ The Britannia Branch of the Canadian Legion wrote a letter to the Hon. Ian MacKenzie, federal Minister of Defense, protesting the sale of iron ore and timber properties to Japanese interests "on the ground the properties involved were vital to Canada's national defense." The purchases of these properties by my father and of other properties by Japanese interests were reported to the Deputy Minister of Lands in a "Confidential Memorandum." ${ }^{5}$ However, nothing was done by the British Columbia government.

A crew of workers was assembled at Lake Cowichan. Some were transferred from my father's Fanny Bay Camp, and others were drawn from Japanese communities in nearby Chemainus, Duncan, and Paldi. Buildings to house and feed the workers, and laying the railroad received top priority.

\section{Camp Life}

The camp was located on the north side of the railroad on Lot $66^{6}$ The buildings were very rudimentary and were constructed of $2 \times 4 \mathrm{~s}$ and cedar shakes, by hand at the site. There was running water, but only from a creek to the kitchen and bathhouse. There was no electricity, no plumbing, and outhouses for toilets. As shown in the "Sketch of Ocean Timber Camp at Cowichan Lake" by Harry Tateishi (on p. 50), the buildings, starting at the left were as follows:

- The Japanese-style communal bathhouse

- The mess hall with a lean-to where Mr. and Mrs. Tateishi and their daughter, Nancy, lived.

6 Harry Tateishi (Interview, October 28, 1999). 
- Six bunkhouses for the workers. The outhouse is about 15 feet above the ground to the north.

- The saw filer's shack.

- The blacksmith's shop

- An old railway car that served as the office and living quarters for Mr. Shimazaki, the superintendent. A spare bed was available for Mr. Kagetsu.

- To the south was the speeder man's shack.

- The Akiyama family, the only other family on site, lived further south.

The camp was known as the "Sunshine Camp" by the local inhabitants because Japan was the "land of the rising sun" and the sun would shine on the camp when the surrounding areas were under cloud cover. ${ }^{7}$

Kikue Tateishi was the cook and her husband Tomehiko was the "bull cook" or helper. Their daughter, Natsue (Nancy), helped her parents and could not attend school because of the camp's location. The cook would wake up at $4 \mathrm{am}$ in order to serve breakfast at 7am. The bull cook's job was to cook the rice in a big pot over a wood fire located outside. The workers served themselves rice, miso soup, and some kind of okazu (side dish served with rice). After breakfast, the workers filled their own metal lunch boxes, and at lunchtime they could warm them up as they did at Fanny Bay. Dinner was served around 6pm. They had rice and various okazu such as chop suey, chicken, beef, and lots of fish. The cook doled out the okazu and everything else was placed on the table. The beverage was green tea. On Sunday morning, they were served porridge with an egg. Sometimes they had bacon and eggs with toast. The workers looked forward to visits from my father because the cook would prepare a special dinner when he was at the camp. Mr. Shimazaki and my father ate in the mess hall.

For entertainment, they played cards such as rummy or poker using match sticks for chips, and some Japanese card games. They listened mostly to popular Japanese songs on an old crank-up gramophone in the mess hall or listened to the radio. Saturday night after work, the speeder would take them to the highway. A few of the younger workers owned cars. They would drive to Duncan and often take in a movie or sometimes attend a dance. Also, they would drive to Victoria and enjoy Chinese food in Chinatown. For the older men, there was a Japanese club in Duncan where they played poker all night. In the summertime, they went swimming in a pool in the creek.

7 Barbara Simkins, Curator, Kaatza Historical Society (Letter to Jack Kagetsu, March 2, 1999). 


\section{Logging Operations}

From May 1 through the end of November 1937, 4.5 miles of railroad were constructed from the E\&N Railway station to Ocean Timber's work site at Lot L66. This project took 70 men and cost a substantial amount of money. There was a big hill on Block 403 that required the building of switchbacks so that the train could handle the steeper slopes. The railroad was built into this new area before logging began.

Prior to hauling logs, a mishap occurred when about 150 feet of railway tracks near the lake sank into soft mud and two 500-gallon oil tank cars overturned into the creek. After the track was repaired, continuous heavy rains stopped the hauling of logs. Finally, the first logs were brought out of the woods and taken by the E\&N Railway to Crofton to be boomed by Crofton Export Co. (Crofton Export). The booms were towed from there to sawmills on the mainland. ${ }^{8}$ To celebrate the first shipment of logs, the Company invited its employees and businessmen from Lake Cowichan to a banquet in the mess hall. The cooks prepared a feast that included maki sushi, age sushi, sashimi, and lots of sake and beer. There were oysters in the shell that my father brought from Fanny Bay.

The superintendent from Japan, Mr. Shimazaki, was in charge of the whole operation. He was a well-educated man and easy to get along with. All the workers liked the way he treated them. Mr. Shimazaki ran the office by himself. He was also a civil engineer and surveyed the land and railroad. As at Fanny Bay, the Japanese were not allowed to operate the locomotive and steam donkey engines. Bill Surgenor from the Fanny Bay camp operated the locomotive with a fireman and a brake man. Also, there were two Caucasian donkey operators. Japanese were, however, allowed to operate the gas and diesel donkey engines. Similar to the Fanny Bay operations, the high lead method of yarding was used and the same types of workers were needed. There were five Caucasian and about 70 Japanese workers.

The section gang built the railroad under the direction of a foreman. The bulldozer operator followed the survey stakes that set the route and grade of the railroad. The saw filer sharpened all the falling and bucking saws. The blacksmith repaired chokers that broke quite often, replaced axes and sledge hammer handles, and made other repairs as required.

The working days were Monday through Saturday with Sunday off. Most of the workers got up at $6 \mathrm{am}$ and had breakfast at $7 \mathrm{am}$. Work started at $8 \mathrm{am}$ and most of the men walked to the work site. They had $3 / 4$ hour for lunch and 
quit at 4:45pm. In those days, the workers were paid only for the hours they worked. They were not paid for holidays or summer vacation. When it was really hot in the summer, the whole operation, including the section gang, shut down because of the fire hazard. The workers had to take a day off and were not paid.

At the end of May 1938, Mr. and Mrs. Fukuzawa arrived in Victoria from Mitsui's office in Seattle. My parents met them there and took them fishing. They stayed overnight at the Ocean Timber camp. The next day they drove along the west coast of Vancouver Island before the Fukuzawas returned to Seattle.

During 1938, the timber market was in a recession and some companies reduced production and cut wages. ${ }^{9}$ Business for Ocean Timber was not profitable. Heavy snow either closed or hampered operations from Christmas into February 1939. Snow slides on the tracks caused trouble. The locomotive was sent to Victoria for repairs during this period. Prospects in the lumber industry were expected to be a little brighter that year. ${ }^{10}$ In June 1939 , the original Ocean Timber partnership was changed to a limited liability company. The Directors were: Eikichi Kagetsu, Carl M. Stewart, Yoshikane Shimazaki, Eiichi Fukuzawa, Seizo Fukuda, and Yugi Yamamoto. The last three men were from the Seattle office of Mitsui. Carl Stewart was my father's lawyer. They met at his office and signed the papers.

In the summer of 1939, there was a long spell of dry weather that stopped logging. Business was not profitable that year. Surprisingly, in October 1941, my father received orders from Mitsui Bussan Co. to immediately sell Ocean Timber. My father recalled:

I couldn't understand but was told we must sell. Initially I started negotiations with Lake Logging Co. and it was with great regret that I decided to sell to Lake Logging Co. Time was of the essence and the sales proceedings were concluded quickly.

For some unknown reason, the workers were not informed that the company was sold. It was common for logging companies to shut down when an area was logged out or when the operation was not economical. The workers were able to find employment at other logging camps. After the operation shut down, Masahiko and Haruhiko Tateishi, the cook's sons, and one other man decided to stay on to remove the remaining logs. They used the railway to take out the logs and logged out whatever they could. Then they purchased their own truck, built a truck road to a different area and took the rest of the logs out.
10 Cowichan Leader, January 5, 1939; February 2, 1939 
Earlier, Haruhiko (Harry) Tateishi was offered a job as a bulldozer operator. He recalled:

I jumped at the chance because I was interested in machinery and became a bulldozer operator. I appreciated the training I got at Ocean Timber. It got me started on a life-long occupation as a heavy duty mechanic.

My father would have been happy to learn that he helped some of his workers in this way. 
TREE TRUNK - MY PILLOW I KAGETSU

56 


\section{CHAPTER 7}

\section{Personal Life}

\section{Raising a Family}

A number of Japanese immigrants came to Canada "to make their fortune" and then returned to Japan. My father had come to stay and became a naturalized Canadian on November 12, 1909, when he received his Naturalization Certificate at the Vancouver County Court. It is not clear when my father's younger brother, Kiunosuke Kagetsu, arrived in Canada. He found work as a watchman at a wharf. On November 29, 1913, he bought a piece of land in New Westminster from his employer, the Surrey Shingle Manufacturing Company Limited. Photos from that period suggest that after my father's logging business failed, my parents may have lived with Kiunosuke who built a shack on that property.

As mentioned earlier, their first child, Hideko, was born in 1912. Their second daughter, Eiko, was born in 1915, their third daughter, Kimiyo, in 1917, followed by their first son, Hajime, in 1918. My father restarted his logging business and became successful. In August 1918, he purchased a house. He paid $\$ 3,500$ for a 3-storey house at 2867 West 37 th Street in Kerrisdale which at that time was part of the municipality of Point Grey. ${ }^{1}$ My father may have gotten to know and like this area while working as a gardener. He selected an area that was separated from the Japanese community.

He spent $\$ 400$ to fix up the house. A flight of steps at the front of the house

Point Grey amalgamated with the city of Vancouver in 1929. For a short history of Kerrisdale, see Davis, 1997. led to the veranda and front door. The living room was to the right of the front hallway and the kitchen was located at the end of the hallway, where cooking 


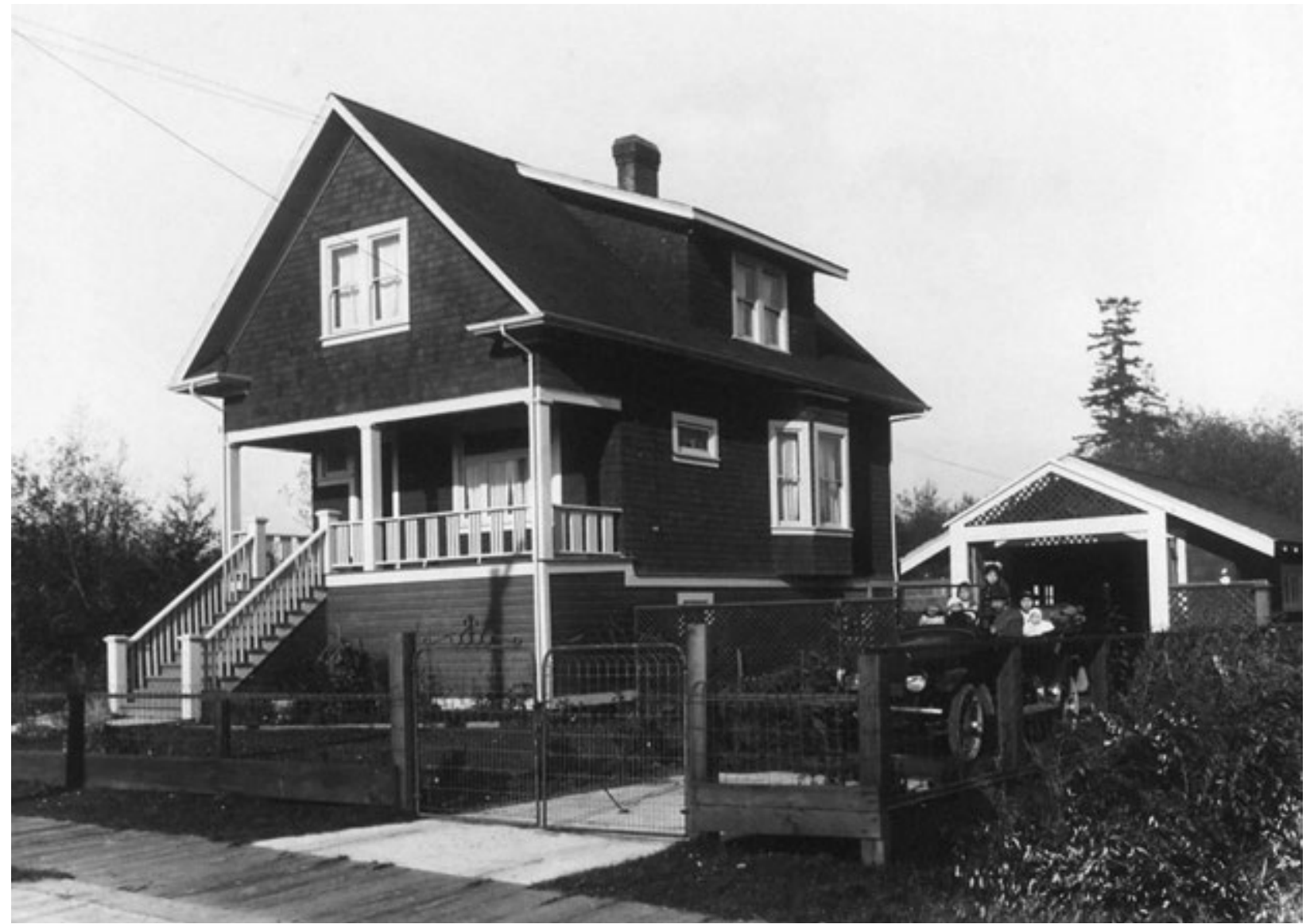

was done on a wood burning stove. The dining room was located between the living room and a pantry. Upstairs, there was a large bathroom and three bedrooms. My father spent another $\$ 450$ to build a fence around the property and to landscape the property that was uncultivated. At the front, he had a flower garden put in and at the back of the lot, fruit trees were planted. In later years we enjoyed the plums, apples, pears, and cherries. Raspberry bushes were planted along the fence.

Other children followed on a regular basis. Takako, another daughter was born in 1920, Hiroshi, another son in 1921 and Akiko, the fifth daughter was

Eikichis home in Kerrisdale (Vancouver) soon after purchase in 1918. 
Eikichi's family (1922). Left to right: Front row: Toyo with Akiko on lap, Eiko, Hajime (seated), Kimiyo, Hiroshi, Takako (seated). Back row Hideko, Eikichi.

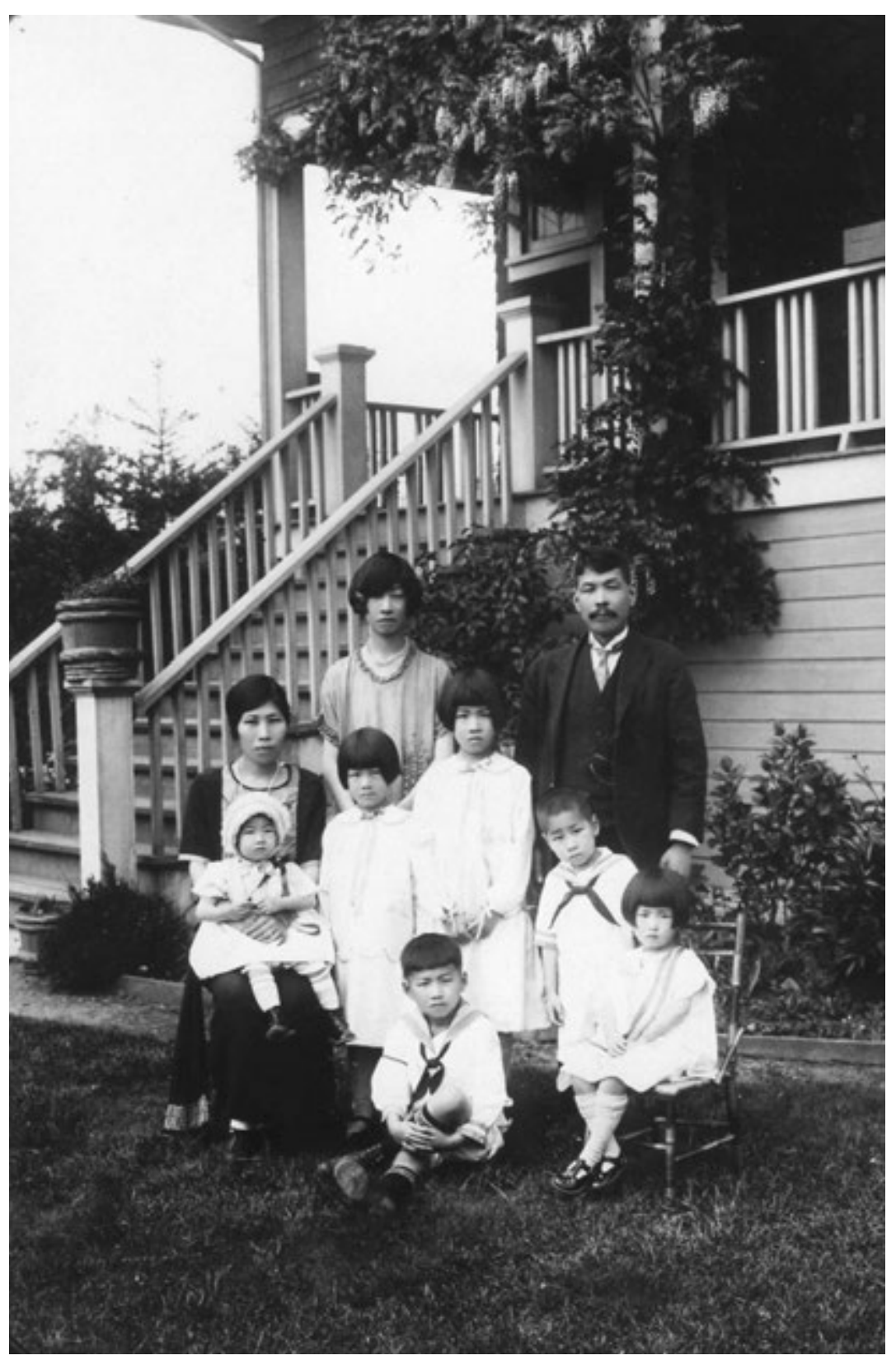


born in 1922. My father bought his first car, a Model T Ford, on April 12, 1920. He enjoyed tinkering with the car and changed the oil when required. During the early 1920s, he had more free time and would grease his car every weekend. After the car was attended to, the family went for a Sunday drive.

My father enjoyed gardening, but as his logging business expanded he reluctantly had to let others do the work. He loved flowers and enjoyed the fresh fruit and vegetables from the backyard garden. My mother took over and planted rows and rows of vegetables in the garden: green beans, green leafy vegetables, cucumber, eggplant, carrots, etc. She was a very capable, efficient, hard-working lady. In the meantime, Hideko completed 8th grade public school and graduated from high school after four years. She then took a oneyear course at a secretarial school, then started working at my father's office in 1930. Mother went with her every day. Three more children were born, a sister, Sachiko, in 1924; a brother, Akira, in 1927 and myself, Tadashi, nicknamed Jack by the nurses, in 1931 .

In 1932, my father spent $\$ 2,664$ to build an addition to our home. Parts of the north wall were removed. The living room was more than doubled in size because the veranda was not extended and the size of dining room was doubled. A new room called the "library" was formed next to the pantry and new dining room. There were bookshelves and a large table in the center of the room where all the children did their homework together. Upstairs, two new bedrooms were built and the one in the middle was essentially doubled in size.

In 1934 our parents, who were married by proxy in 1910, celebrated their Silver anniversary. In the Japanese counting system, your age is counted as one in the year that you were born; the same applies to the years of one's marriage. This happy occasion was commemorated with a sterling silver set consisting of a teapot, coffee pot, hot water pot, cream and sugar, and numerous napkin rings, all on a large tray. As was the Japanese custom, my father was the "boss." Mother was second in command. We never questioned their authority, nor did we dare to disobey them. However, in those early days, I believe that was the situation in most families regardless of their racial origins.

My father never brought "work" home, nor did he spend time at home phoning people. He took care of business matters at the office. He belonged to many organizations and was usually elected the president or appointed chairman of an important committee. He was a good organizer and delegated the detailed work that needed to be done. Some meetings were held in the evening. He was a modest man and never talked about his achievements.

After coming home from the office, my father would ask me to translate items in that day's newspaper. I believe it was his way of making me aware of 


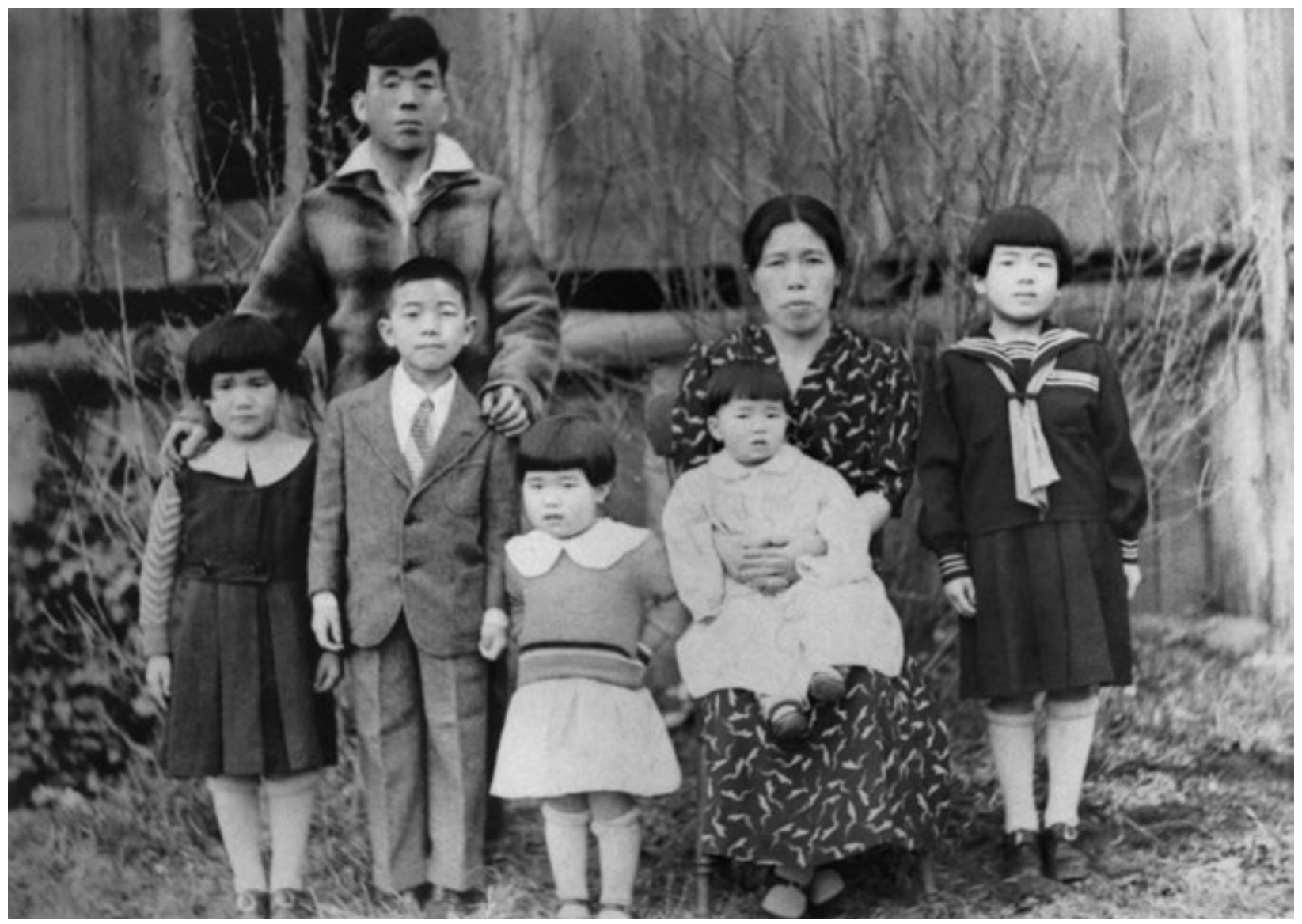

Left to right: Tsurutaro Kagetsu

(Eikichi's younger brother) Yoshiko, Susumu, Tsuyuko, Reiko on mother Hide's lap and Natsuko. Missing: Tetsuo born 1939. what was going on in the world and to develop translating skills. Later, one of the older children would do a more thorough job. My father's English was not good enough to read the newspaper himself. When my brother, Hajime, began to attend UBC, my father bought him a coupe with a rumble seat. In 1940, my father decided to have a double garage built. Hajime, Akira and I tore down the old garage. The new garage was built further back so that the cars could maneuver in and out easily. Sadly, a cherry tree had to be cut down to make room. 
My father patronized the Japanese businesses that supplied the goods and services our family needed. Tomekichi Maikawa who owned a general dry goods store and Sannosuke Maikawa who owned the fish market were good friends of my father. He would stop by at the Maikawa Fish Market where the clerks would offer him the most expensive items, because they knew that my father would never say "too expensive" even if a less pricey quality would have been adequate. He bought life insurance for himself and for all the children from different Japanese representatives. The policies were of the endowment type that was the most expensive.

\section{Loss of Loved Ones}

My grandmother, Yoshi, worked as a housekeeper in Hollyburn where my parents lived for a period of time after my father's logging business failed. She contracted tuberculosis and died on January 25, 1912. She was buried in Mountain View Cemetery in Vancouver. Due to the illness of my other grandmother Ei Nakamoto, my mother Toyo, and her two young daughters, Hideko and Eiko, boarded the Canada Maru at Victoria and sailed to Japan in October 1915. My mother was present when her mother died on January 24, 1916. They left Kobe for home two months later.

On January 11, 1917, Kiunosuke, my father's brother, married Tamie Hamaguchi by proxy. The 20-year-old bride arrived in Canada on May 29, 1918. The newlyweds lived with my parents in their new home in Kerrisdale. Sadly, Tamie died of pleurisy five months later. On June 21, 1924, Eiko, our sister, died of scarlet fever. The funeral and cremation was held three days later. My mother was in the hospital expecting the birth of Sachiko and missed the funeral.

On April 1, 1925, my father received a telegram from Japan informing him that his father, Hisakichi Kagetsu, had died. My mother left Victoria nine days later on the Arizona Maru with Hajime, the chonan (oldest son) to represent my father, and Sachiko, their youngest child at that time. They attended our grandfather's funeral. The trip was timely as my mother took Eiko's ashes to Nishi Honganji Temple in Kyoto. My mother and her two children left Kobe on July 4 on the Africa Maru and arrived safely in Victoria after nineteen days of sailing.

Sometime during 1935, my eldest sister, Hideko, had a tonsillectomy. The hospital conducted a chest X-ray before she was discharged and discovered that she had tuberculosis. Because there were so many children at home, she was taken to a rented two-room house on the beach in North Vancouver where 
2 Norton, 1999.

3 Enders, 2009

4 Tom Shoyama (Interview, September 11, 1998). she was cared for by a private nurse. My sisters, Akiko and Sachiko, accompanied my mother when she went to visit Hideko. My parents, who were very concerned, visited her every weekend. The nurse, who had been hired for a given period, couldn't continue. Check-ups showed that this was going to be a long-term recuperation.

Two spinster sisters, in their sixties and seventies, agreed to care for Hideko in their home in North Vancouver. They could feed her and take care of her but they weren't nurses. Hideko's condition wasn't improving so my father wanted to get a real nurse. In order to accommodate them, he located and purchased property in West Vancouver near Fisherman's Cove that consisted of a sloping mountain side. The spectacular view took in a cove from which the tide would ebb and flow, an island, part of the coast and the ocean beyond. This view must have been reminiscent of his home near the coast in Japan.

The main floor of the house had a large living room, a large kitchen/dining area and two bedrooms. It had running water and indoor plumbing. A stairway built on the rocky slope led to a lower level where there was one large room. There was the soothing sound of running water as a small creek flowed under the house. The house was winterized for Hideko. There was a porch outside the living room at the front of the house where Hideko could rest and enjoy the wonderful scenery.

Miss Foster, a young private nurse was hired to take care of Hideko. Generally, the family would visit on weekends. On occasion, my mother and Takako, who was taking time off school because of severe headaches, would visit during the week. They were constantly consulting Dr. Vrooman and other doctors who recommended 24-hour care. The illness dragged on. The nurse got engaged and could not continue much longer. In early 1937, the decision was made to transfer Hideko to a 300-bed TB sanatorium at Tranquille, over 200 miles northeast of Vancouver near Kamloops. The Tranquille Sanatorium had a reputation as being one of the finest in North America. ${ }^{2}$ The dry and mountainous climate was ideal for recuperating TB patients. There was no treatment, just bed rest. The staff did everything for them. ${ }^{3}$

Family friends, the Shoyamas, ran a bakery in Kamloops. Mrs. Shoyama contracted TB in the middle 1920's. She did not want to go to the sanitorium. She stayed in bed in her room to get plenty of rest. The main concern was not to spread this infectious disease. It was a big job for Tom and his sister Fumi to do the laundry because everything had to be sterilized. Mrs. Shoyama stayed in bed for about a year and was cured. ${ }^{4}$ Tom Shoyama went to Vancouver to attend University of British Columbia (UBC) in the fall of 1934. He got to know Kimiyo, Hajime, and Takako. When he went back to Kamloops in 1937, he vis- 
ited Hideko. The Shoyama family felt empathy for Hideko. Mitsu, Tom's younger sister, and her parents visited Hideko regularly and took Japanese food to her. Our family became very close friends with the Shoyama family and their kindness towards Hideko will always be remembered. Visits by family members were less frequent because of the distance. My mother and Akiko went by train. On occasion, Akiko, who was sixteen years old at that time, would stay one day and return to Vancouver by herself.

Hideko wrote the following poignant letter on May 6, 1937.

\section{Dear Kimiyo!}

Many Happy Returns of the day to you on your birthday. I really think you are a very lucky girl. Just think how widely you have traveled at your age, to the coastal cities of the U.S.A., Mexico, across Canada, England, Scotland, France, and Germany. Then you are quite accomplished, spending two years at varsity, meeting notable people, and making acquaintances. I wish from the bottom of my heart that your life will continue to be very happy and eventful as it has been until now.

You have been a good sister to me and I am proud of you, in fact we all are. Since I am unfortunately not well and able, you are the onesan (eldest sister) of the family. This fall if you and Takako go to Japan, I hope you have a very nice trip.

You have also been fortunate in regards to friends such as Norie (Yamanaka) and Roger (Obata). I am sure you value their friendship very much. A friend like Norie whom you can trust and confide in, to whom you can talk to about everything with an open heart, is I think a treasure. As I haven't what I call real intimate friends, I am very happy for you.

Well I shall close now by again wishing you Happy Birthday dear Kimiyo,

\section{Yours affectionately, Hideko Kagetsu}

As time passed, Hideko's condition improved and she looked and felt better. By March 1938, she was cured. I remember the excitement when she was coming home. However, it was not meant to be. Hideko died on April 1, 1938, the night before she was to come home. Joyful anticipation turned into sorrowful 
mourning. Although Hideko was a Christian, my parents gave her a Buddhist funeral. Because my father's prominence in the community, there was a very large attendance at the funeral held at the Hompa Buddhist Temple. A reporter from a local Japanese-language newspaper described the funeral as follows: ${ }^{5}$

The hall was filled with flower wreaths offered by individuals as well as various organizations. - It was a grand but solemn service. - During the sutra chanting-offering of incense by representatives of various organizations and individuals was performed. After the incense offering, eulogies were read by the various organization representatives. - The remains were cremated at Mountainview Cemetery. It is reported that 704 attended the funeral and that there were 135 wreaths offered.

The urn with her ashes were placed by the butsudan (family altar) at home. In Hideko's memory, my father donated one thousand dollars to the Tranquille Sanitorium to further TB research. ${ }^{6}$

\section{Trip to California}

My mother's oldest brother, Katsutaro Nakamoto, who had gambled away the family savings, had emigrated to California where he grew oranges. Once a year, he would send a crate of navel oranges to our home in Vancouver along with a box of walnuts. In 1934, my mother decided to visit him by car accompanied by Kimiyo, Hajime, and Hiroshi. Since the trip was going to be very long, my father asked Sadao Maikawa to do the driving. In August, they drove directly to Katsutaro's home in Riverside about 50 miles east of Los Angeles. Sadao recalls that as they traveled south, they had to let air out of the tires because of the heat.

It must have been a happy reunion for my mother. Katsutaro showed them his orange orchard and explained how the trees were watered. A flume carried water to the orchard and a gate controlled the flow. Young trees were circled with water and all the water was used before it reached the road at the end of his orchard. Katsutaro showed them a spectacular view of the Riverside area from Mt. Rubidoux and the unusual trees and cactus plants. After saying goodbye to Katsutaro, they travelled to see interesting attractions in San Diego, Long 
San Francisco, Sonoma, and Seattle. Among the places they visited were the Japanese gardens and Buddhist temples.

\section{Entertainment / Recreation}

My father led a busy life. Once or twice a month he would travel to Vancouver Island to oversee his logging operations. As my father's business became established and as he became involved in the Japanese-Canadian community, he spent less and less time at home. Nevertheless, he found time to spend with the family.

Early on we were not allowed to play cards as my parents associated card playing with gambling which was strictly prohibited in my family. When my father went to his logging camp, the car ferry to Vancouver Island took close to three hours in those days. Some of the regular commuters played bridge to pass time and my father watched them from time to time. On one trip, the bridge players needed a fourth player and so they taught my father how to play bridge. This was remarkable because his English was not that good, he was not a card player and he had to grasp the concepts of a trump suit and bidding. Evidently, he was a good student and played well enough to enjoy the game. He came home and taught my mother and the older children. His acumen is further illustrated by the fact that he never sorted his cards although he held them in a fan. Only the top bridge players could hold a fan and many others couldn't at all. If not the first, my parents were among the earliest bridge players among the Isseis.

My brother, Hajime, studied Ely Culbertson's honour count system that formalized the bidding. Culbertson was a popular promoter of the game of bridge during 1930s. Bridge became popular with the Niseis and the New Canadian, a Japanese-Canadian English language newspaper, carried a bridge column during the first half of 1940. As the older children needed a fourth player, the younger children were taught how to play. I was taught to play around the age of six or seven.

During 1937, Hajime had minor surgery on his wrist. While he was recuperating, he built a chess set, using the motor from the washing machine as a makeshift lathe to turn out the pieces. The ends of wooden spools were used for the base of the large pieces. He taught his siblings how to play. An uncle from Japan visited us about that time. According to my sister who was seven 
years older than me, I used to beat my uncle at checkers. She figured he was an easy mark and challenged him to a game. To her surprise, he beat her handily.

Occasionally my father and I played "pick-up-sticks" on a Sunday morning. The game consisted of letting a bundle of sticks with different colored tips fall randomly on the floor. The objective was to pick up the sticks one by one and extra points were earned by picking up certain colored sticks in sequence. You lost your turn if any of the remaining sticks moved while you were picking up the selected stick. Often when I moved a stick my dad would grunt and let me play on.

My father helped me play with a battery-operated train set, a hand-medown, which had a light on the front of the locomotive. The bulb burned out and my father brought home a replacement the next day. Even at that young age, I was happy that he remembered to buy the bulb despite his busy schedule. I also remember that my brother, Akira, built kites. My father brought a piece of cedar about four feet long from Fanny Bay. Strips of cedar and string formed the frame that was covered with brown wrapping paper using paste made from cooked flour and water. A tail made of strips of brown paper of varying lengths was necessary to stabilize the kite. My brother won first place in one of the categories at a kite-flying contest held at the school grounds. My father gave him a dollar bill in recognition of his achievement.

My father played golf at Banff in 1934 (see photo p. 127). However, there is no indication that he played golf in Vancouver. Kimiyo and Hajime had their own set of golf clubs and played regularly. I remember accompanying Hajime to the Langara Golf Course in West Vancouver and watching him play. While attending UBC, he would on occasion ask Henry Arikado, who worked in my father's office, out for a game of golf during working hours when my father was at Fanny Bay. As chance would have it, my mother wanted Henry for something. Mother called Henry's wife and asked her if she knew where her husband was.

In rural Japan, my parents were never exposed to European classical music. In Vancouver, they had all my sisters take piano lessons. In the mid-1930s, our upright piano was donated to the newly built Hompa Buddhist Temple and my father bought a Heintzman baby grand piano. Kimiyo concentrated on playing the violin. Hiroshi played the French horn. On special occasions, we had a family concert, each one played a solo on his or her instrument. Some JapaneseCanadian artists became well known to the public. My parents attended concerts given by artists such as Aiko Saita, Lily Washimoto, and others.

I don't know if it is a Japanese custom, but from the earliest times, family photos were taken by a commercial photographer. The same is true with our 
family. We had a simple box camera and a Kodak camera that opened up with bellows that allowed the lens to be moved back and forth to focus. Our family album had many photographs that documented our life as we grew up.

In 1934, my father purchased a Bell and Howell $16 \mathrm{~mm}$ movie camera. He took movies of his logging operations at Fanny Bay, of the Vimy Pilgrimage and 1936 Olympics, of the dedication of the Hompa Buddhist Church and Bussei Renmei Monument, of the Wakayama Kenjin Kai picnic, and of family activities. Even though the movie camera was very heavy without a tripod, the movies were steady. I don't know if he received any instructions, but he used techniques such as panning slowly, using signs for identifying the place or attraction, and going to the end of a train to catch the locomotive and front part of the train going around a curve.

Our family enjoyed spending an evening watching movies. My father also bought short features including cartoons to add to the fun. On occasion, an evening would be spent editing the movies. I can remember helping to splice the ends of a cut film. It was hard work for me to scrape off a strip of emulsion on the end and to press down hard on the splice until the glue set.

Evidently in the 1930's, movies were not very common. My father was invited to show the movies of his logging operations at meetings of local service clubs such as the Kiwanis. My sister, Takako, remembers accompanying my father and giving the commentary for the silent movies. In 1978, the films were donated to the National Archives of Canada. The appraiser stated: ${ }^{7}$

Mr. E. Kagetsu is an avid photographer and the quality of his work is comparable to that registered by the most professional cinema photographers of the mid- and late 1930's. - The record on 16mm motion pictures film is a valuable and priceless contribution to our ethnic archives.

During the summer, our father would take the family to Kitsilano Beach. Our treat at the beach was potato chips (French fries) in a cone-shaped paper cup sprinkled with vinegar.

Occasionally, we went to watch a Japanese-Canadian baseball team called "Asahi." The team gradually won the respect of everybody by their excellent play and sportsmanship. In 1925, they were voted the most popular team in the city. ${ }^{8}$ The Asahi baseball team kept up their winning ways both on and off the diamond and built up an enviable record of league championships. This baseball team was a unifying force and a source of great pride among the Japanese Canadians. ${ }^{9}$
7 Galloway, B. (February 14, 1978). National Archives of Canada Appraisal Report No. 116.

8 The New Canadian, May 27, 1939.

9 Adachi, 1992, pp. 5, 53, 75. 


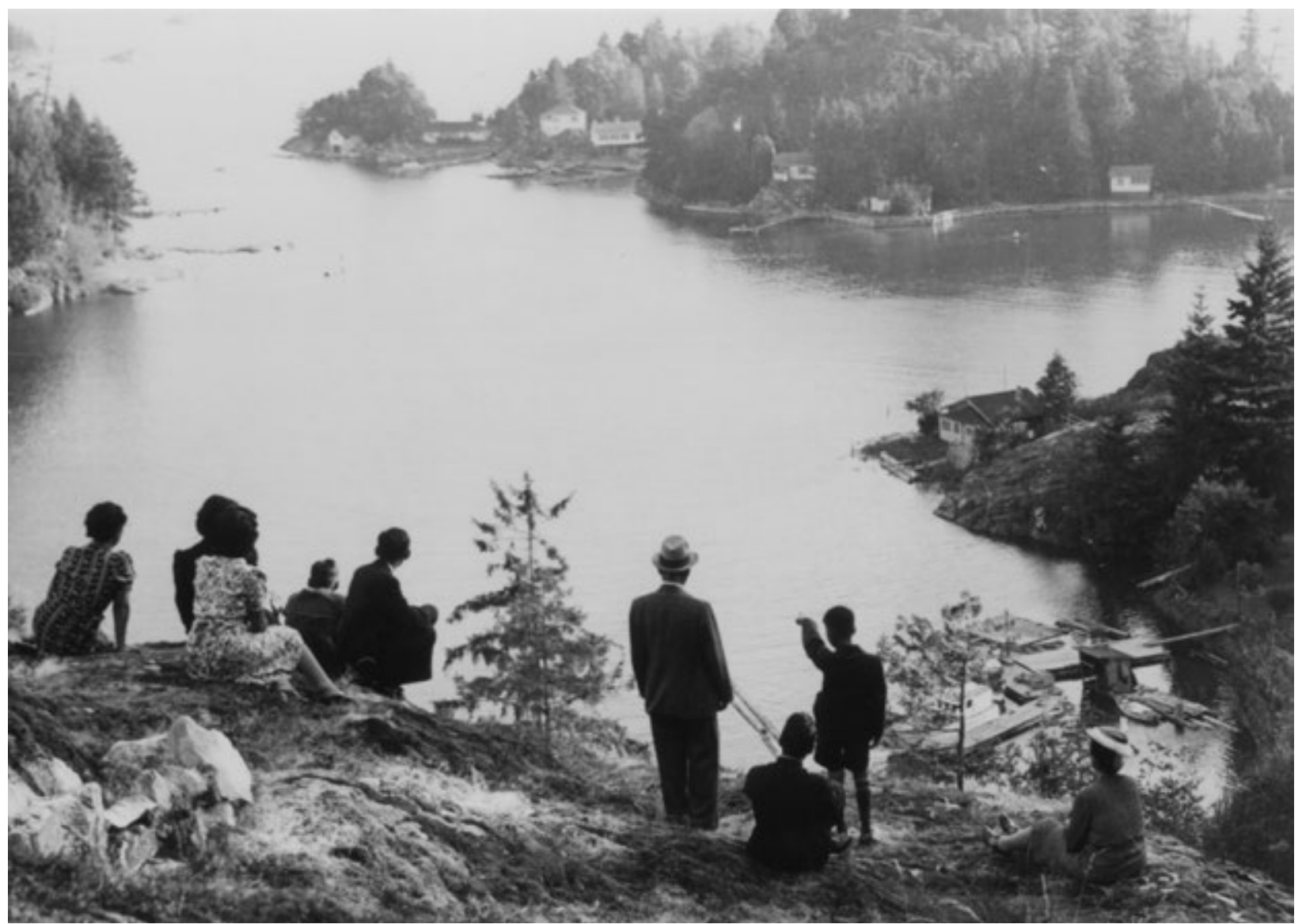

View from the highest point on the summer house property in West Vancouver.

10 Tajiri, L. The Great Dictator Likes Tempura. The New Canadian, November 29, 1940. Reprinted from the JapaneseAmerican Mirror.

Once in a while, the family would attend the local movie theater. My father's favourite movies featured Joe E. Brown and the Marx Brothers. My mother liked Charlie Chaplin movies such as The Gold Rush and The Great Dictator. My parents liked these comedians because they could enjoy what was going on even if they had difficulty understanding the dialogue. My parents would have been happy to learn the following about Charlie Chaplin: ${ }^{10}$

The first public utterance made by Chaplin was delivered one night in August 1934, on Weller Street in the heart of Los Angeles' Little 
Tokyo. His audience was a crowd of some 10,00o Japanese gathered for the final event of the first Nisei festival, the "ondo". He had come from Hollywood to the Japanese section of the city that night to eat rice and tempura. He still remembered vividly the wonderful reception given him when he had visited Japan some years previously. - He spoke for brotherhood and understanding, of goodwill among the varied peoples of the world. It is the same Chaplin who speaks so sincerely in the final minutes of The Great Dictator. It isn't the Chaplin of the baggy pants, the twirling cane, but a man who feels deeply in his heart for the sufferings of the little people of the world.

\section{Summer House}

After my sister was transferred to a TB sanatorium, we would often go to the "summer house" on weekends or holidays. My father could relax in the sun and spend time with family and friends. Further up the mountainside, a badminton court was built. Canvas strips were held in place with U-shaped wire to outline the court for singles and doubles. We all enjoyed playing badminton.

My father had projects in which the family participated. We built an arched bridge at the back of the house over a little stream. At a spot with a beautiful view located above the house on the mountainside, we built a round picnic table using the round end of a large cable reel from the Fanny Bay camp. Fixed benches were built around it. Friends, including the children's friends, were often invited to the summer house. Sometimes they would rent a boat with an outboard motor and go trolling. Special guests such as the Hompa Middle School teachers or groups from Japan or elsewhere were feted there. The Hompa Young Peoples' group, the Kumamoto Young People's Group ${ }^{11}$ and others used the facilities at the summer house.

Takako and Hiroshi came back from Japan to spend the summer at home. My father hired a commercial photographer to take family pictures at the summer house. One picture was taken at the top of our property with a spectacular view of the area. Hiking up the path, I must have disturbed a hive of bees. My mother picked three bees off my ankle with her bare hands. One got up my sleeve. The pain made me cry. A second picture was taken by the arched bridge behind the house. My father carried a frown. On the way home, he lectured me that men do not cry. 


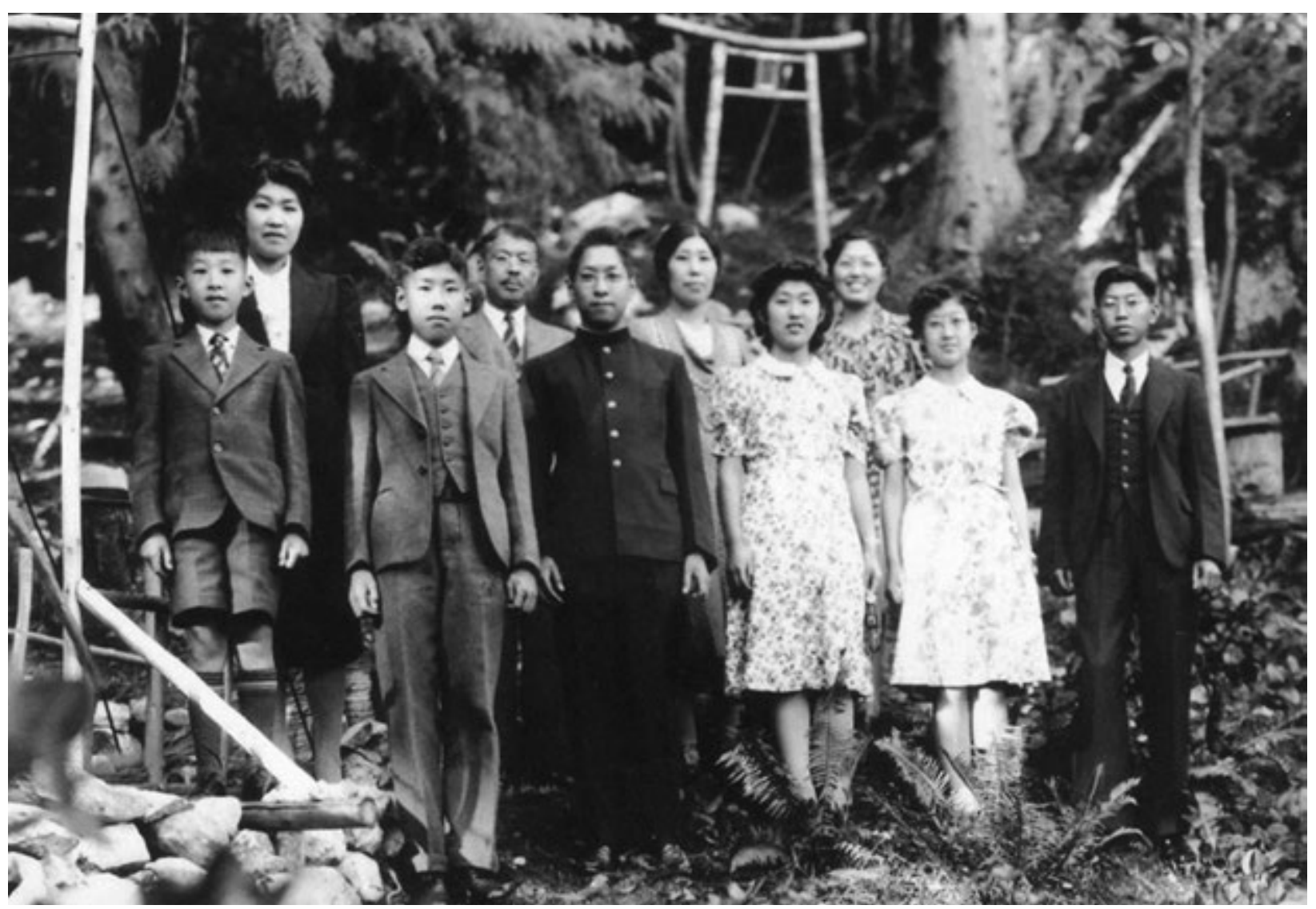

Eikichi's family at summer house in 1940. Left to right: Tadashi, Kimiyo, Akira, Eikichi, Hiroshi, Toyo, Akiko, Takako, Sachiko, Hajime.

Around 1941, my father bought an adjacent lot and had a driveway cut up the hill to the house. We went there before the driveway was completed. On the way home, my father had to back the car down the driveway. The car got stuck in the muddy ditch beside the driveway. The whole family had to pitch in before the car finally got free. We had a dock and two row boats. Hiroshi, my second oldest brother, built a sailboat at home in Vancouver and sailed it to our dock. He sold it to a friend and in 1937, he built a bigger sailing boat. My mother grew up by the sea and was a good swimmer. My father couldn't swim.

My father enjoyed fishing as did the rest of the family. To go fishing, we would row to Fisherman's Cove, which was located about half a mile further 
along the highway. We would scrape seaweed and small shells off the dock and find sea worms that were used as bait to catch shiners. The shiners were kept alive in a submerged box with holes. Then we would row out to the island across from Fisherman's Cove. Our favorite fishing spot was on the windward side of the island close to shore. A wiggling shiner would be skewered on a large hook and the line would be lowered to about a foot off the bottom. The first time I fished, I almost lost the line. The rock cod gave the line a big pull and I struggled valiantly as the line was pulled in.

On the drive home, my father would make a detour to Fisherman's Cove and buy everyone an ice cream bar, the kind with chocolate and tasty nuts on the outside. This was a big treat as we didn't get to eat ice cream very often. When we got back to Vancouver, we would stop at our favourite Chinese Restaurant, Fuji Chop Suey House. My father had the chef prepare shappan with the freshly caught rock cod. Everyone enjoyed the dinner, especially the fish.

We have many happy memories of our summer house. 
CHAPTER 8

\section{Maintaining Japanese Traditions}

\section{New Year's Day ${ }^{1}$}


My father attended the Japanese Consul's open house in the morning. There was the usual toasting with sake and a table with delicious food for the guests. My father also invited his friends to our house after the celebration at the Consul's residence. Throughout the day more than fifty men would converge on our home. Champagne and sake were served. Even though my mother spent many days preparing the delicacies for New Year's Day, she would apologize to the guests, as any good Japanese hostess would, saying, "I'm sorry there isn't much but please try it" or "It doesn't taste good but please sample it." On New Year's Day, the men would make the rounds of visiting close friends and partake of the delicious food prepared by the lady of the house.

\section{Kigensetsu ${ }^{3}$}

An important Japanese national holiday, Kigensetsu, which literally means "eraceremony," falls on the 11th day of February, which is said to correspond to the first day of the first month of the year when Emperor Jimmu, the first emperor of Japan ascended to the throne 660 years before the Christian era. This National Foundation Day has been designated as one of the four great national holidays.

\section{Hina-matsuri ${ }^{4}$}

In Japan, they did not celebrate father's day or mother's day. Instead, on the 3 rd day of the 3 rd month, they celebrated the girls' festival that was more popularly known as the "doll festival." A set of ceremonial dolls, a heritage of the household, was handed down, from generation to generation, and for a few days they were displayed in the best room of the house. A set usually consisted of at least 15 dolls, all in ancient court costumes of silk.

The dolls most highly valued were the Odairi-sama representing the Emperor and Ohina-sama representing the Empress. All were displayed on a hina-dan that consisted of a tier of steps, usually 5 , from 3 to 6 feet long and covered with a bright red cloth. The Imperial couple occupied the top tier, court ladies and banquet trays and dishes occupied the second tier. The other dolls were arranged on the lower tiers.

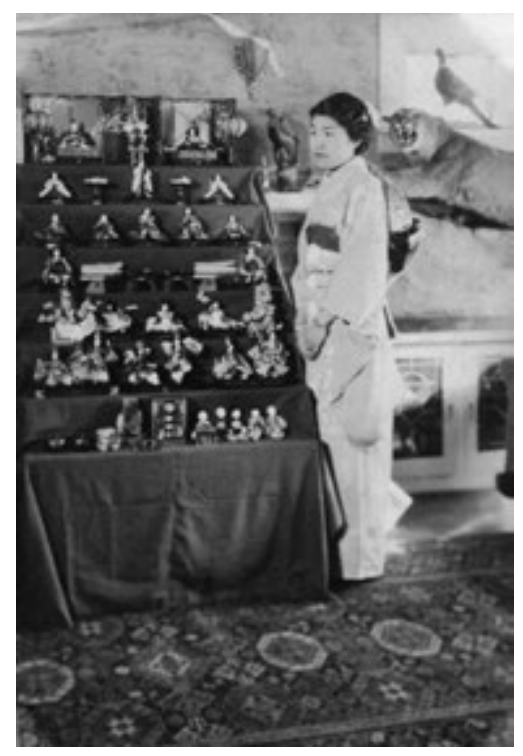

Hina Matsuri (Girl's or Doll Festival). Kimiyo Kagetsu by hina dan.
3 De Garis, p. 185.

4 De Garis, p. 56. 


\section{Boys' Festival $^{5}$}

The boys' festival, tango no sekku, was celebrated on the 5th day of the 5th month. In our home, the boys each had a replica of a famous feudal warrior complete with miniature paraphernalia of swords, armour, helmets, banners, etc., that depicted a scene which indicated the significant feature of the hero. I was the only one that had two replicas. These images were displayed in a special alcove in the best room of the house.

\section{Cultivating Chrysanthemums}

Chrysanthemums that are popularly grown in modern times were imported from China in the 9th century. ${ }^{6}$ The Japanese had elevated the cultivation of chrysanthemums to a fine art. During the fall, competitive exhibits were held in almost every city along with chrysanthemum-viewing parties-an age-old practice in Japan.

Japanese immigrants brought this love of growing chrysanthemums to Canada. My father enjoyed cultivating chrysanthemums as a relaxing pastime. I remember helping him to make the wooden pots and painting them green. I'm sure my father was very selective with the soil he used to fill the box. After he planted the cuttings, I watered the chrysanthemum plants regularly. In order not to "shock" the young plants, my father would let the water warm up in the sunlight. I believe he pinched off certain parts as the chrysanthemum plant grew. We were rewarded with a variety of beautiful chrysanthemums.

The Kokonoye Kai (Japanese Chrysanthemum Society) was formed in 1930

5 De Garis, p. 58.

DeGaris, pp. 278-279.

The New Canadian, July 10, 1940.

The New Canadian, December 18, 1940.

9 The New Canadian, October 18, 1940.

10 The New Canadian, November 8, 1940; The New Canadian, October 2, 1940. and saw the birth of ten similar organizations in Vancouver and nearby municipalities. ${ }^{7}$ Its motto was "promotion of friendship between Japanese and Canadians through chrysanthemums." ${ }^{8}$ The Kokonoye Kai sponsored a Chrysanthemum Exhibit annually at the Japanese Hall in October. ${ }^{9}$ As part of their tenth anniversary celebration, the Kokonoye Kai participated in the largest chrysanthemum show ever to take place in North America. Five thousand blooms were exhibited at the Exhibition Gardens in Hastings Park in November 1940. ${ }^{10}$

Some 1500 chrysanthemum blooms representing 10 different varieties of chrysanthemums were displayed at the Eleventh Annual Mum Show in 1941 by over 350 entries. Alderman Charles Jones who was himself a chrysanthemum 
grower of note, opened the exhibition. The 5,000 visitors included Mayor J.W. Cornett of Vancouver and his wife. Mayor Fred Hume of New Westminster, who was also into growing chrysanthemums, made a brief appearance. My father presented the cups and other prizes. The best bloom in the entire show went to Mr. S. Y. Takahashi who was awarded the "Kagetsu Cup" for his gorgeous "Henry Truman." ${ }^{11}$ There was a banquet attended by over 70 Canadian guests from five chrysanthemum societies in the greater Vancouver area. Alderman Charles Jones cited that a deeper understanding of and friendship with his Japanese acquaintances were tangible results of a common love for chrysanthemums. The Kokonoye Kai's motto was fulfilled in many ways.

\section{Judo}

Professor Jigoro Kano developed judo in Japan in the 1880's by combining the principles of jujitsu with techniques that involved mental discipline. The objective of judo is to lead an opponent into an off-balance position by giving way and that resulted in the efficient usage of energy. ${ }^{12}$ The first place where judo was practiced in Canada was called the Tai-iku Dojo. It was started in Vancouver by Shigetaka Sasaki in an apartment and changed locations as it grew. My father, Eikichi Kagetsu was among the early patrons. ${ }^{13}$

Dr. Jigoro Kano visited the Tai-iku Dojo on his return from the 1932 Olympics in Los Angeles where he lobbied to get judo included in the Olympics. He renamed the dojo Kidokan and made all other dojos in British Columbia branches of the Kidokan. Dr. Kano added to this special occasion by granting honorary black belt status to three members of the dojo: Eikichi Kagetsu, Gentaro Isobe, and Toshiaki Sumi. Dr. Kano created this unique position because the recipients worked harder than a judoka, gave their dedication financially, mentally, spiritually, and physically, but had never competed in a tournament. ${ }^{14}$ My father wore his judogi or judo outfit when he proudly accepted this award.

My father enrolled my brother and me in a judo class. Judo was practiced barefoot on a tatami, a mat which covered most of the floor. Proficiency in the sport was designated by the color of the belt you wore. As a beginner, I wore a white belt. The highest was a black belt, which had additional degrees of proficiency.

My father took us to watch the All Canada Judo Championship Tournament at the Japanese Hall. A thousand spectators enjoyed an evening filled with
11 The New Canadian, October 10, 1941; The New Canadian, October 17, 1941.

12 Leyshon, 1988, pp. 10-12.

13 Leyshon, pp. 19-20; Svinth, 2003, p. 200.

14 Sasaki, S. (n.d.); Leyshon, p. 25. 
thrills and surprises when over 100 participants battled for individual and team championships. We rooted for participants that were good friends of the family and were glad when Minoru (Frank) Hatashita won the All Canada Black Belt competition in 1938, 1939, and 1941, and was presented the beautiful Nemichi Challenge trophy. ${ }^{15}$

\section{Japanese Movies}

Once in a while, our father took us to watch a Japanese movie at the Japanese Hall. A writer described one type of Japanese movie as follows: ${ }^{16}$

...if the feature film involved a chanbara (swordsmanship)-a "western" in a manner of speaking - we sat eagerly awaiting that moment just when the lone "Good Guy" surrounded in ambush, ominously and slowly drew his trusty katana (sword) out of its scabbard with the resulting mayhem of a small army of baddies being mowed down.

I never figured out how the "Good Guy" could survive when surrounded by so many "Bad Guys" all with drawn swords.

These Japanese movies had no soundtracks. The script was read by Mr. Tsuyuki who changed his voice for each character, including women. He was so good that you would swear it was a sound movie. He operated the projector and had a small light for reading. Once, when my mother took me to the restroom, we walked by the projector and I still remember seeing Mr. Tsuyuki drenched in perspiration.

\section{Japanese Medicine}

15 The New Canadian, March 1, 1939; February 28, 1941; Tairiku Nippo, Ferbruary 24, 1941; Leyshon, p. 108.

16 Marutani, B., Pacific Citizen, April 19May 2, 1996.
My father was not a tall man. He was built solidly probably because of the hard labour he endured during his younger days. He utilized Japanese methods to relax his muscles and body. My mother and sometimes one of the children would massage the muscles in his arms and legs. We would clench our hands and pound his back with alternate fists as we moved the point of impact around his back. Once in a while, on a weekend morning, I "walked" up and down my 
dad's back and on the back of his legs and arms as he was lying on his stomach on the bed. I think I was the right weight as I was the only one asked to do this. Many of my brothers and sisters did this when they were younger. He had wooden "pillows" that had a triangular and a semi-circular cross section. These were placed under spots where he wanted to apply pressure. Occasionally, a professional masseuse would come to the house. The practitioners and the method of massage was called anma in Japan.

There were other traditional Japanese medical practices which my father used, like acupuncture. By stimulating key points in the body-most commonly with needles-an acupuncturist seeks to restore balance to the normal energy flow and, consequently, to relieve or treat disease. The acupuncture points can be stimulated by needles, low electrical currents, heat, or finger pressure. Stimulating acupuncture points with heat is known as "moxa combustion," "moxabustion" or okyu in Japanese, and is used by some medical doctors as part of what is now called alternative medicine. Heat is produced by igniting tiny cones of moxa that are applied on the skin at specific points. The heat from the burning of the moxa produces a pleasant feeling. The points to be stimulated are selected according to the disease or symptoms being treated. A "moxabustioner" would come to our home and select points based on what my father wanted. He was spotted with black scars from this treatment. My mother could repeat the treatment by using the scars to locate the points. I might add that when we were bad, we were threatened with moxa combustion. My father had a book titled Secret of Curing Illnesses with Moxa Combustion. ${ }^{17}$

\section{Japanese Books}

My father had a wide variety of books in his library, many of which were given to him. The Japanese Consul in Vancouver presented my father with special books that commemorated special events. These books were not for sale and were in great demand. There is an album on Emperor Meiji with views of the Imperial Palace never seen by the public before.$^{18} \mathrm{My}$ father received a similar album on Emperor Taisho. ${ }^{19}$

My father had contacts with Japanese throughout North America as indicated by two books: History of Japanese in North America ${ }^{20}$ published by the American Japanese Association and lists the Presidents of the Canadian Japanese Association from its beginning in 1909 through 1940. The other book titled Wakayama Kenjin Kai U.S.A., Canada and Mexico ${ }^{21}$ has photos of fam-
17 O-kyu de byoki wo naosu hippo [Secret Method of Healing Sickness with Moxabustion], 1933.

18 Meiji Tennō Oshashinchō Kankōkai, [Album of Photos of Emperor Meiji], 1929.

19 Meiji Tennō Oshashinchō Kankōkai, [Album of Photos of Emperor Taisho], 1927.

20 Hatayama, 1940.

21 Hieda, 1965. 
ilies and a directory of families who came from Wakayama Prefecture, and who were living in these three countries.

Books were sent to my father from Japan that described projects such as the Wakayama Prefecture flood relief to which he contributed. ${ }^{22}$ He helped sponsor an exhibit by the Military Arts. ${ }^{23}$ My father had over a dozen books written in Japanese presented to him by various Christian groups that probably received donations from him.

\section{Japanese Food ${ }^{24}$}

Most people are familiar with the long grain rice served in Chinese restaurants. Japanese use short grain rice which is softer and sticky, and hence is sometimes referred to as "sticky rice." The uncooked rice kernels are called kome and cooked rice is called gohan. In my family it was customary to serve the first portion of cooked rice in a bronze container similar in shape to an eggcup but smaller, using a wooden paddle. Usually one of the children took this offering to a small Buddhist altar located in my father's bedroom. Although the children were raised as Christians, we were exposed to certain Buddhist customs.

My father had diabetes that he controlled by diet. At home, my mother cooked him mugi gohan or barley cooked like rice. In the Wakayama Prefecture where my parents grew up, they cooked rice with green tea to form a brown colored gruel called okayu, chagayu, or cha-gai. Okayu means "porridge," and cha means "tea." Thus, chagayu or chagai is literally "tea porridge." People from Wakayama Prefecture simply called it okai. Even though people from other prefectures ridiculed this practice, the Wakayama locals loved it. In 1929, two warships of the navy training squadron from Japan visited Vancouver. Admiral Nomura who led this group was from Wakayama Prefecture and my father invited him to our home. His first request was for some chagayu.

Another favourite food of our large family was mazegohan (literally mixed rice). There were several varieties of vegetables-carrots, gobo (burdock root), takenoko (bamboo shoot), age (fried bean curd) for protein, and shiitake

22 Wakayama ken sui gai kiroku shashin shu [Wakayama Prefecture History of Natural Disaster with Photographs] (1953).

23 Rikugun Bijutsu Kyōkai, 1939.

24 Tsuji, 1990. (Japanese mushroom) - that were cooked, chopped up and mixed with the rice. Matsutake (a special mushroom) gohan and oyster gohan were mother's specialties that the family and guests loved. Both matsutake and oysters were highly desired delicacies that we took for granted because dad was able to get them at Fanny Bay. 
Growing up in the fishing village of Ena, my mother loved fish. We ate a lot of fish, such as sashimi (sliced raw fish), mackerel or salmon with oroshi (grated white radish). Fish was often cooked with teriyaki, and salted, or broiled. My father would put all the unedible parts of the fish such as bones, head, etc. in his empty rice bowl, pour green tea over it, and drink it after it had soaked a while. My mother often remarked that no matter how much she loved fish, she could never do that!

My father was away at camp a lot. My mother put in a vegetable garden, and after supper while it was still light, she tended the garden. She had neat rows of green beans and a couple of rows of green leafy vegetables. The family was usually together at dinner time. One of my sisters recalled:

When we were real small, dad would come home from work and have a carafe of sake and munch on fresh vegetables. One evening he came home earlier than expected. The vegetables were not ready and so mom asked me to prepare the green onions. I was young and inexperienced. I cut off the roots, quickly ran tap water over it and took it to my father. The first thing he did was to peel off the outer leaf to show me that I had done a poor job of washing it. He wanted to teach me the proper way to do things and I went back to the sink and washed it properly. As we grew up, dad would often correct us.

My father liked to eat unusual food such as tanpopo (dandelion leaves), warabi (bracken fern) which were plentiful at our summer house, and fuki, that resembled thin rhubarb in structure. A Chinese cook at Fanny Bay taught my father how to cook chicken in a special way. At the Maikawa Fish Store, my father selected a live chicken and the clerk chopped the head off. At home, my mother pulled out all the feathers and used a burning roll of paper to remove the quills remaining in the skin. The chicken was then broiled in the oven while being basted with soy sauce containing garlic to form a crispy, tasty skin. We ate the chicken meat with garlic shoyu (soy sauce). The family liked it. Kimiyo and Takako said "merci" when the chicken was served and the dish became known as merci. The next day, the older kids were teased because the garlic was still on their breath. Garlic is not used in Japanese cooking and so merci was an enjoyable change.

From time to time, my father would go out to lunch or dinner with his Caucasian business associates. He particularly liked the idea of eating a salad with green vegetables. At home, the thing he stressed most often was to make 
sure that we ate our "veggies" especially the "greens." At one lunch he enjoyed "oxtail soup." At the dinner table that evening, he mentioned it and told my mother that they should make it at home. I could only visualize a tail with hair and dreaded the thought of eating oxtail soup. 
TREE TRUNK - MY PILLOW I KAGETSU

82 


\section{CHAPTER 9}

\section{Education is a Top Priority}

\section{Public Schools}

G etting their children well educated was one of my parents' top priorities. This was true with other immigrant groups. A good education was essential for assimilating into Canadian society and hopefully getting a good job.

During my preschool years, I was home with my mother who spoke to me in Japanese; her English was very poor. As a result, I didn't understand either language very well. My mother told me the story of George Washington cutting down a cherry tree, and when questioned he admitted doing it; he could not tell a lie. The Japanese love stories that extol virtue. School children in Japan all knew of George Washington's honesty and that he became the President.

Kerrisdale Public School was four blocks from our home. I started grade 1 in 1937 at the age of six. Miss Bruce, our art teacher, was a student of Miss Nesbitt and a classmate of my sister, Hideko.

One day, my father told me to ask the principal, Mr. Houston, if he would like to show movies of my father's logging camp to the students. I now believe that he wanted me to get experience in talking to and dealing with people in authority. Mr. Houston was happy to accept the offer. About six of the lower grades filed into the auditorium and sat on the floor to view the movie. At one 
point, there was a scene showing the Japanese flag flying on a pole above a gazebo. There was booing by the audience. The principal stopped the movie and gave a lecture on respecting the flag of other nations. The movie was shown with no further incident.

Our third grade teacher, Miss Eastman, knew the Canadian poet, Bliss Carman. She made his poems come alive. Bliss Carman came to my sister Sachiko's class.

For grades 7 through 9, students attended Point Grey Junior High School that was about a mile from our home. Hiroshi and Akiko rode their bikes to Point Grey. The principal, Mr. McCorkindale, was widely liked. The students started French in grade 7. Their French teacher, Miss Marion Langridge, had trained at the Sorbonne in France. The girls got home economics and the boys got woodwork. My brothers and sisters all took the typing option in grade 8. As each student had an individual schedule of courses it was difficult to get to know the other students. The school had a swimming pool where many of the students learned to swim.

Magee Senior High School offered grades 9 through 13. A student who completed grade 12 received a junior matriculation and could then proceed to university. Those not going to university could go on to grade 13 and receive a senior matriculation. Magee offered academic, commercial, and technical courses.

My sisters and brothers took the academic route and studied mathematics (geometry, trigonometry, algebra), social studies (history and geography), foreign languages (German, French, Latin), and English (grammar, composition, literature). Takako was the smartest and "skipped" a number of semesters.

In a newspaper "vignette," a reporter wrote: ${ }^{1}$

A girl who takes Senior Matric Chemistry, who belongs to the Chemistry Club and who likes Algebra best of all her subjects is Akiko Kagetsu. Despite all that, she has a charming and friendly personality. When away from her chemistry lab, she finds time to excel at table tennis and badminton; and applies her algebraic skills to the mathematical intricacies of contract bridge.

Since Magee Senior High School was over two miles from our home, my father would drive family members and sometimes their friends, especially when they were running late. One morning as my father was leaving for the office, he broke a shoelace. He tied the broken ends together as he did not have a spare shoelace. Later that day, he had an appointment at the bank to apply 
for a loan. The loan officer approved the loan and told my father that anyone frugal enough to tie a broken shoelace could be trusted to repay the loan!

\section{University of British Columbia (UBC)}

On November 27,1934 , the Japanese Students' Club (JSC) ${ }^{2}$ held a meeting at the home of Mr. and Mrs. Eikichi Kagetsu to hear an address titled "The Legal Disabilities of the Japanese Canadians Including the Second Generation in British Columbia." The speaker, Mr. Sherwood Lett, was a prominent lawyer in Vancouver, one of the earliest Rhodes Scholars from UBC, and a member of the executive committee of the Japan Society of Vancouver. My father must have sat in on this meeting to hear a topic of great interest to him. The paper dealt with provincial regulations that prevented Japanese Canadians from voting, from entering certain professions, and from working in certain industries. ${ }^{3}$

My sister, Kimiyo, enrolled in first year Arts in the fall of 1936. She was not academically inclined and enjoyed the social life at UBC. During the fall of 1936, she attended three dances. Each attendee was given a printed card that listed all of the dances and the men signed the ladies' card to reserve one or more dances.

"To discover for University students lasting values in the modern world" was the purpose of a student conference held in Seattle from December 27 to 30, 1936 by the Student Christian Movement from Alberta and British Columbia, representatives of the YWCA and YMCA, and college branches in the United States. The largest delegation at the conference came from UBC and included Irene Uchida and Kimiyo Kagetsu. ${ }^{4}$

Intercollegiate debates between the JSC and a similar group at the University of Washington were popular events. To publicize the 1937 debate at UBC, Miss Kimiyo Kagetsu arranged flowers in the traditional Japanese art of ikebana and displayed them at the reference desk in the library. ${ }^{5}$ The two teams were entertained at a party held in the home of Mr. and Mrs. Eikichi Kagetsu. ${ }^{6}$

To commemorate the beautiful and unique girls' festival or hina-matsuri, (See Chapter 8), the girls of the JSC, under the convenorship of Miss Kimiyo Kagetsu, held an informal tea at the home of Mrs. E. Kagetsu. The girls were all dressed in colourful kimonos. Samples of Japanese art, handicrafts, and flower arrangements, as well as the traditional hina-dan delighted the guests. During the afternoon, Miss Lily Ide entertained the guests with piano solos, while Misses A. Kinno and K. Kiya performed Japanese dances. The approximately 20 guests included Mrs. R. E. McKechnie, the wife of UBC's Chancellor, 
Mrs. L. S. Klink, the wife of UBC's President, wives of the Deans of several faculties, faculty, and women executives of UBC. ${ }^{7}$

The fifth annual graduation banquet of the JSC was held at the Fuji Restaurant on April 24, 1937. ${ }^{8}$ The printed programme listed the 1936-37 officers as follows: President, Roger Obata; Vice-President, Albert Takimoto; Treasurer, Hideo W. Iwasaki, Secretaries, George T. Tamaki and Kimiyo Kagetsu, Social Convenors, Irene A. Uchida, Kunito T. Shoyama, and Freshman Representative, Kiyoaki Momose. Honorary guests were Dean Daniel Buchanan, Dean J. N. Finlayson, Japanese Consul Hon. H. Nemichi, Professor H. F. Angus, and Mr. Eikichi Kagetsu. After dinner, Hon. H. Nemichi proposed a toast to the King and Dean Buchanan proposed a toast to the Emperor of Japan. Dr. Miyazaki and G. T. Tamaki spoke to the graduates, and Roger Obata responded on behalf of the graduates.

Kimiyo dropped out of UBC after one year to study in Japan. Hajime enrolled at UBC in the fall of 1937 to study Forestry. Our father bought him a new coupe with a rumble seat to drive to UBC campus. In 1940, fourteen Nisei students were enrolled in the freshman class, including five Niseiettes, namely: Akiko Kagetsu, Shinko Nagata, Taka Nikaido, Lillian Shimotakahara, and Lily Uyeda. The JSC held a "Frosh Reception" at the Killarney to welcome the freshmen. ${ }^{9}$ The JSC's first meeting for 1940-41 was held at the home of Mr. and Mrs. Eikichi Kagetsu. $^{10}$

Tom Shoyama recalls that he was at an impressionable age, and asked my sister Takako who was about 17 or 18 at that time for a date. My mother reluctantly agreed, but sent Takako's younger sister, Akiko, with them as a chaperone. When she looks back, Akiko was very embarrassed because she stayed close by instead of at a discreet distance.

Nisei students of the University were pleased at the announcement made by Col. G. M. Shrum and President L. S. Klinck that they continue with military training. Commenting on the recent government announcement that Japanese be exempt from compulsory training, President Klinck said that the Senate ruled that all able students must undertake military training. ${ }^{11}$

The Cosmopolitan Club and Social Problems Club of the University of British Columbia held a joint meeting that featured, "The Oriental on Trial," at the home of Mr. and Mrs. E. Kagetsu. Hajime Kagetsu, vice-president of the Cosmopolitan Club, was chairman. Bob McMaster, former student leader and practicing law in the city, was the prosecutor, Jerry Hundal was the defense witness and the audience was the jury that failed to arrive at a decision. ${ }^{12}$

The New Canadian reported: ${ }^{13}$
7 Three articles, unknown newspapers, March 6 \& 8, 1937.

8 For a description of the 9th Annual Banquet see The New Canadian, May 1 , 1940.

9 The New Canadian, September 25, 1940

10 The New Canadian, October 11, 1940.

11 The New Canadian, January 17, 1941; Eagles, 1957.

12 The New Canadian, February 7, 1941.

13 The New Canadian, March 21, 1941. 
For the second time in the history of the local University Students Club, a scienceman, Hajime Kagetsu, was elected president at the final meeting of the club, which was held at the home of Dr. and Mrs. K. Shimotakahara. "I plan to incorporate new ideas into our program and to hold as many meetings as possible with other campus clubs in order to foster better relations," the new president said. The other 1941-42 officers were as follows: Vice-President, Kimi Takimoto; Treasurer, Roy Nose; Recording Secretary, Katherine Shimotakahara; Corresponding Secretary and Publicity, Hideo Shigei and Charles Kadota; Social Convenors, George Yamashita and Akiko Kagetsu, and Past-President, Kiyoaki Momose.

One evening at the dinner table, Hajime told my father how a group of Japanese pulled up UBC students' survey stakes. The Canadian Japanese Association (CJA) sent a written apology for the incident to the University. Tom Shoyama stated that the Japanese Students' Club at the University was an important outlet for the Nisei, who were frustrated, insecure, naïve, innocent students grasping for a future in an unfriendly, hostile world. ${ }^{14}$

\section{Japanese School}

As was the case with most Japanese families, our parents wanted their children to learn the Japanese language. Around 1927, my father hired a private tutor, Mrs. Kikuchi, who came to our home to teach the older children to read and write Japanese. Later, the Fairview Japanese Language School was founded by its principal, Rev. Zesei Kawasaki. Grades 1 though 6 were taught in the basement of the Fairview Buddhist Temple. My mother didn't want the older children to miss attending Japanese school. She often said, "I will do anything that I have to for the sake of the children." In 1930, she learned to drive so that she could take the older children to Fairview Japanese School located 10 miles away. A friend commented, "That was a very impressive thing for a Japanese woman, as no other Japanese woman drove a car at that time."15 Fairview started after regular school at $4 \mathrm{pm}$ and invariably the Kagetsu children were tardy because they lived so far away. In March 1933, Kimiyo graduated 6th grade from the Fairview Japanese Language School, and Takako the following year.

My father was instrumental in starting the Hompa Chugakko, a Japanese language middle school for grades 7 and 8 in the new Hompa Buddhist Temple
14 Tom Shoyama (Letter to Jack Kagetsu, December 11, 2000).

15 Kay (Hatashita) Hayashi (Interview, August 1999). 


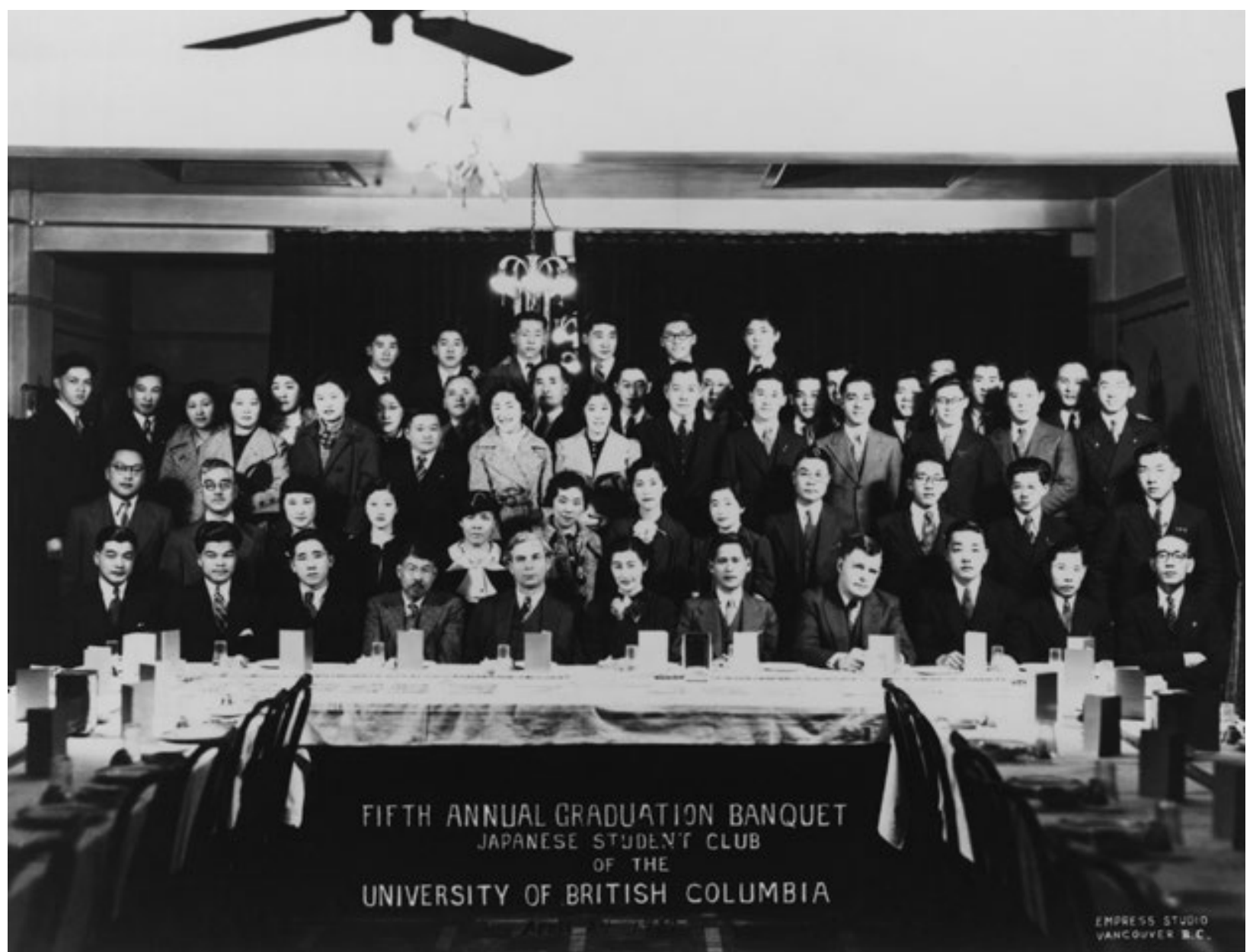

(see Chapter 13). No tuition was charged as my father paid for the teachers, textbooks, and supplies. Rev. Zesei Kawasaki became the Director of the Hompa Middle School. Classes were held for two hours 6 days a week. Subjects included Japanese language, grammar, composition, geography, and calligraphy. In addition, shushin (ethics), tea ceremony, ikebana, music, manners, and etiquette were taught to promote the spiritual growth of the students. There
Japanese Students' Club (University of British Columbia) Fifth Annual Graduation Banquet held on April 24, 1937. Front row: 4th from the left Eikichi Kagetsu; 3 rd from the right Roger Obata; on the right Dr. Masajiro Miyazaki. 
16 Kawasaki, 1992, p. 3

17 Kay (Hatashita) Hayashi (Interview, August 1999).

18 Fireflies, Snow and Auld Lang Syne, 1998 p. 250. A stamp showing two students, a girl and a boy, was issued on 3 May 1948 to publicize postwar education reforms. The author of this article wondered why the sheet margin was decorated with fireflies. His research describes how by an unlikely chain of events, fireflies symbolize diligent study-and Japan's graduation song. were eight or nine teachers for the 65 students. ${ }^{16}$ Kawasaki sensei was one of the most charismatic and effective teachers encountered by our family.

Between 1933 and 1935, Mr. Kazuta, who worked in my father's office, used the company car to drive my sisters and brothers to and from Japanese school. Later Henry Arikado drove Akira and me to Fairview after school and the others to Hompa in the evening. Kay Hatashita Hayashi recalls the following: ${ }^{17}$

Kimiyo and Takako invited their Japanese School classmates to a house party, and I was included too, much to my delight. I'm sure the guests all enjoyed the party tremendously in an enlarged house with double size living room and dining room. Also, it must have been a new experience to be in front of a movie camera-we hardly moved.

Akira and I attended Japanese School at the Fairview Buddhist Temple. Rev. Hirahara was the principal. Academically we did poorly, but he treated us better than we deserved because our father was so prominent in the Japanese community. We received a report card every quarter and our parents acknowledged seeing it by imprinting the family han or stamp instead of signing it.

At graduation time, all the students were assembled and practiced singing Hotaru no hikari, a graduation song that referred to the light of fireflies and sung to the tune of Auld Lang Syne. I recently came across the following explanation: ${ }^{18}$

Two high officials in early fifth-century China were lauded for having risen from extreme poverty by diligent study. The parents of Cheyin were too poor to buy oil for a lamp, so he gathered fireflies in a bag and read by firefly light. Sunkang studied by moonlight reflected from snow on the windowsill of his parents' poor home. Late in the sixth century, Japan began adopting Chinese culture and Confucian ethics, including the stories of Cheyin and Sunkang, called Sha-in and Son-ko in Japanese.

In 1881 the Education Ministry published a songbook for use in elementary schools-including Auld Lang Syne with a new title Hotaru no Hikari (Firefly Light) and an unknown Japanese writer's new words that have no connection with those of Robert Burns. Japan's school graduation song begins with light from fireflies or reflected from windowsill snow-sung to the 1796 tune of Auld Lang Syne. 
At the graduation ceremony, top students were recognized, and every student received a certificate showing that he had completed a particular grade, including a prize consisting of school supplies, such as notebooks, pencils, etc.

Not only did we learn Japanese at Japanese school, but we learned much from our parents. Words in Japanese often describe things better than the corresponding English word, or in a more colourful way. Also, many of the words had to do with proper behaviour, etc. Japanese parents made sure that their children did not sully the family name and reputation. Our actions must never bring haji or shame to the family. ${ }^{19}$ Chanto shinasai implies doing things properly, according to the rules. ${ }^{20}$ When someone offers to help, to do something for you, to give you something such as food, a gift, etc. and you really would like to accept, but you decline, the Japanese say that the person enryo suru. Literally it means "reserve" but includes an element of shyness or of not wanting to impose on the giver. If you waste something or throw away something that can be used or eaten, the expression is mottainai.

\section{Education in Japan}

In 1936, on the return trip from Europe, Kimiyo, Hajime, and Takako got to talking about their future. It was assumed that Kimiyo and Hajime would continue at UBC. Takako, who was sixteen at that time, was in her senior year and had to decide what to do. Takako told the others, "I want to do something different. I want to go to Japan to college rather than UBC." After discussing this desire, they agreed that it was a good idea. Both parents initially had misgivings about sending Takako away, but faced with such determination agreed to the idea. It was decided that Kimiyo would accompany Takako to Japan.

Mr. Suzuki, the editor of the Canada Daily News, and his wife were good friends of the family. Mrs. Suzuki was a graduate from Nihon Joshi Dai, Mejiro and knew Mrs. Hide Inouye, the President of this Women's University. When she visited Vancouver, the family met her and entertained her at our summer house. The question regarding Takako enrolling at Nihon Joshi Daigaku was raised and Mrs. Inouye said that it could be arranged. Through this connection, Takako was able to enroll in Nihon Joshi Daigaku, Mejiro, the Wellesley University of Japan.

A Tairiku Nippo reporter wrote: ${ }^{21}$
19 The Power of Haji, Pacific Citizen. Oct. $15-21,1999$.

20 Rediscovering the Chanto Principle, Pacific Citizen, June 23-29, 1999.

21 Tairiku Nippo, October 1937. 
The daughters of Eikichi Kagetsu, Kimiyo and Takako, aspiring to study in Japan, will leave at the end of the month on the Empress of Japan. Kimiyo has finished 2 years at the University of B.C. and in March graduated from the Hompa Bukkyo Middle School. Takako graduated this year from Magee High School and is in her 4th year at Hompa Bukkyo Middle School winning highest honour prizes.

It is interesting to note that these young ones after travelling all over Europe, should turn round and be interested in learning more about Japan, the land of their ancestors. There was no outside influence. Was it a genetic impulse? The fact that it was self-generated makes it even more admirable.

Mr. Fukuma was the Japanese Consul in Vancouver in the late 1920's and was a good friend of my father's. On Kimiyo and Takako's first trip to Japan in 1937, the boat stopped in Hawaii. Mr. Fukuma, who was stationed there as the Consul General, invited them for dinner and his driver picked them up. At the end of the meal, they were served papaya, a delicious fruit that they had never eaten before. Mrs. Fukuma's father, Saichi Nakayama lived in Azabu-ku, Tokyo. He was Kimiyo and Takako's guardian in Japan and his son, Sasao, took care of them. They stayed in a YMCA dormitory from November 1937 to March 31, 1938. When Mr. Nakayama went to war, his wife took care of my sisters.

The Nihon Joshi Daigaku was founded by a Japanese man named Dr. Jinzo Naruse, who studied in the United States and became a devout Christian. The campus was pretty modest and consisted of a number of wooden buildings.

Takako attended Nihon Joshi Daigaku from April 1, 1938. The courses covered everything including chemistry, physics, philosophy, history, literature, Japanese literature, etc. This school stressed English and the class studied English every day. At the beginning of each English class, Takako's teacher would ask her to read a passage. The courses were at the junior college level. Takako did three times as much homework as the other students because she had to learn the language at the same time.

The outer dormitory where Takako lived was run by a professor of English who was a missionary from England. Her niece, who was also a missionary, led the Bible class and gave private English lessons. The students got up at 5:30 every morning and cleaned the whole dormitory. A bell rang at 6:30 for chapel. Chapel was followed by breakfast. At the dormitory, four or five students took turns preparing the evening meal. Many of them were from wealthy families and had never cooked before. 
The chapel was adorned with a cross and two candlestick holders. In the morning, the students had a 15-minute service before breakfast and in the evening after supper and a little break they had another 15-minute service. If you lived in this dormitory, it was compulsory to attend these services. At the start of each service, they sang a hymn. A passage from the Bible was then read and the missionary explained the meaning. This was followed by a prayer and a few minutes of silent prayer. The professor and her niece both gave Bible classes for students from other dormitories. They were Episcopalian or Anglicans, called Seikokai in Japanese. Quite a few students came to the chapel for the Sunday service. Since Takako was very conscientious, the professor's niece gave her private lessons on the Bible. With the war approaching, she left and her replacement asked Takako to conduct one of the daily services. During that service, she took a certain Bible passage and explained and discussed it. Takako also accompanied the singing of hymns by playing the organ.

Takako got a special dispensation so that Kimiyo could live with her in the dorm. Kimiyo enrolled in a school for Nisei students to learn Japanese. She studied the art of bonkei-miniature landscapes presented in a shallow porcelain dish or tray. ${ }^{22}$ Natural scenery is depicted by stones and sand or simulated using papier-mâché that is painted. Artificial trees, and flowers as well as tiny models of people, animals, houses, and other objects were used to complete the composition. She mastered the Japanese tea ceremony and gave demonstrations when she returned to Canada.

During the school break in July and August 1938, Kimiyo and Takako came home. The first class deck overlooked the lower deck where Kimiyo and Takako were playing with others. A man on the first class deck called down, "Kagetsusan." He was Mr. Noritake of Tamura Shokai. He thought Kimiyo was a Kagetsu because she looked just like her mother and took a chance in calling down. Kimiyo and Takako were invited up to the first class section and were introduced to other men. When they landed in Vancouver, Mr. Noritake, Mr. Miyazawa a Congressman, Mr. Masao Saneyoshi, and the other men they met on the boat were invited to dinner at our home. One of the men was Viscount Mishima, the leader of the Boy Scouts in Japan. In the fall of 1938, Kimiyo went to Japan one more time with Takako.

In early 1939, Rev. T. Matsumoto, a former Anglican missionary in Prince Rupert, organized a Nisei group in Tokyo to assist the second generation in Japan to keep in contact with the Church. The organization called itself the Sigma Kappa Theta Society ${ }^{23}$, and issued a 16-page mimeographed magazine to mark its first anniversary. Canadian members were Takako Kagetsu, Secretary of Vancouver, and Satoshi Kanaya, and H. Yamanaka of Prince Rupert.
22 De Garis, 1950, p. 21.

23 The New Canadian, February 23, 1940. 
Nihon Joshi Daigaku had a number of students from Manchuria studying on the campus. The Japanese government was courting the Manchurians to keep them happy and wanted to treat these students in a special way. Just before Pearl Harbor, in order not to make it look too obvious, Prime Minister Tojo invited all the students from foreign countries including Takako to his residence, where they were served tea.

My parents decided to send Hiroshi to Japan with Takako in the fall of 1939. Hiroshi attended a university attended by Niseis to learn Japanese for one year. He then attended Keio University, another prestigious university that was inaugurated as the first private university in Japan in 1890 . He enrolled as a fulltime student in economics and made many good friends.

\section{Christian Education}

Our parents were devout Buddhists and my dad was a pillar of the Buddhist Church. While my oldest sister, Hideko, was attending school, some of her friends invited her to attend Sunday school at the Knox United Church, located adjacent to the Kerrisdale School playground. She pleaded with our father to allow her to go. After thinking about it, he decided that all his children should be raised as Christians, the predominant religion of his adopted land. A number of Buddhists had children who attended the local Christian Church. This was accepted by the priests and other Buddhists.

My father learned the significance and importance of Christmas and Easter in the Christian Church and attended Church services celebrating those holy days at Knox United Church. At Christmas, he took a box of mikan, Japanese oranges, to the Minister, Rev. Munro who found Mr. Kagetsu "very amiable."

We celebrated Christmas in our home. My father brought home a nicely shaped fir tree from the Fanny Bay Camp and set it up in the living room. The older children decorated it. Everyone, including our parents, talked about Santa Claus and why we young children should behave. On Christmas morning, the youngest children, including myself, would get up early and rush to the living room. Usually, we received one gift from Santa Claus and one gift from the family. Every Christmas, the family distributed close to 20 boxes of Japanese oranges to all our neighbours. Takako remembers asking my mother when she was young, why we gave the same thing every year. Mom's answer was, "because everybody loves Japanese oranges and they happen to be some- 
thing that represents who we are-Japanese Canadians." The oranges were individually wrapped and came in a small wooden box.

The Easter Bunny would come and hide chocolate eggs all over the house. Akira and I had to search very hard as the older children were clever in finding hiding places. We had a bear rug in the living room and an egg was hidden between the bear's teeth. There was a clothes rack in the kitchen that we had to lower to retrieve another egg.

I was home with mother while all the other children were at school. My mother taught me to sing "Jesus Loves Me" which she must have learned from Hideko.

Our family members did not participate in any of the activities of the downtown Japanese United Churches probably because we lived in Kerrisdale, which was some distance away. We did not know that people such as Rev. Kosaburo Shimizu of the Powell Street United Church and Miss Florence Bird, who was a missionary in Japan from 1912 through 1922, would play an important role in our lives in the future. ${ }^{24}$ 
CHAPTER 10

\section{A Man of Faith in Action}

\section{The Heaps Temple}

1 Rev. Tsuji (Interview, May 26, 1998).

2 Ikuta, 1981, pp. 21, 25.

3 Tairiku Nippo, October 22, 1910.

4 Ikuta, pp. 25-26
$\mathrm{T}$ he majority of Japanese who immigrated to Canada were Buddhists of the Jodo Shinshu sect. The sect was founded by Shinran Shonin (11731263), a Buddhist monk, who preached to the masses all over Japan. Jodo Shinshu followers are found throughout Japan, making it the most popular sect. ${ }^{1}$ In 1904, a group of faithful followers in Vancouver were successful in inviting Reverend Senju Sasaki-from the Nishi Honganji, the sect's mother temple in Kyoto- to lead them.

The Buddhist church grew under Rev. Sasaki and in 1909 a building committee was formed to build a new church at a new site. The existing building and land were sold in January of the following year. The proceeds were used to purchase two lots at 1603 Franklin Street. It was located in the Heaps District of Vancouver and became known as the Heaps Buddhist Church. Construction of the wooden structure started on October 21, 1910, and completed four months later at a cost of $\$ 28,445.00 .^{2}$ The church was constructed with two storeys in the front, two 120 -foot high towers, and three storeys in the back. ${ }^{3}$

The new Church was dedicated at an opening service on September 25, 1911. The temple bell rang to assemble the congregation and the priests filed into the hall as music was played. At the end of the service, fourteen individuals, including Eikichi Kagetsu, were recognized for their dedication to the successful completion of the new Church. ${ }^{4}$ 
In 1912, Rev. Sasaki returned to Japan after six years of dedicated service. He was replaced by Rev. Gungai Kato. Members complained about him to the Nishi Honganj. The mother temple sent Rev. Junichi Shigeno to resolve this issue. But soon a serious rift developed among the church members. Things got so bad that a meeting was called in October 1920 to deal with the problem, but it only reinforced the differences. Those who opposed Rev. Shigeno drew up a new constitution, forming the Canada Bukkyo Kai (Buddhist Churches of Canada). It was recognized by the Nishi Honganji which later sent Rev. Takun Nishimoto to be installed as the head minister of the Canada Bukkyo Kai. ${ }^{5}$ Twice during the next two years, the Nishi Honganji sent a priest to bring the two sides together, but to no avail.

In September 1924, the North America Buddhist Association sent two priests, who with the help of Consul Gomyo, met with the two factions separately and got both sides to agree to an amalgamation. Eikichi Kagetsu was in the group that represented the Heaps Church. After two weeks of negotiations, the two churches met on December 22, 1924. Eikichi Kagetsu was the master of ceremonies and Matsunoshin Abe presented the resolutions that were all passed.

\section{Canada Hompa Buddhist Church}

The two churches were united under the name Canada Hompa Buddhist Church. The following executive committee of the new church was elected.

$\begin{array}{ll}\text { President: } & \text { Eikichi Kagetsu } \\ \text { Vice-Presidents: } & \text { Matsunoshin Abe and Gentaro Nakagawa } \\ \text { Secretary: } & \text { Ritsu Ide } \\ \text { Treasurer: } & \text { Momotaro Honda }\end{array}$

The Buddhist authorities in Canada believed that the Nisei should be taught Buddhism in a way that was compatible with their lives in Canada. In October 1926, the Right Rev. Renshi Sonyu Ohtani from Nishi Honganji visited Vancouver to evaluate the situation so that an appropriate program could be developed. ${ }^{6}$

The Buddhist churches in Canada originally came under the Buddhist Churches of North America. In 1930, they petitioned Nishi Honganji to become an independent entity. Their request was approved in 1933 and the Buddhist Churches of Canada was formed. On February 25, 1933 the President of the Hompa Buddhist Church of Canada, Kannosuke Kaminishi, died. Eikichi

5 Ikuta, pp. 28, 34-36

6 Watada, 1996, pp. 69-70. 


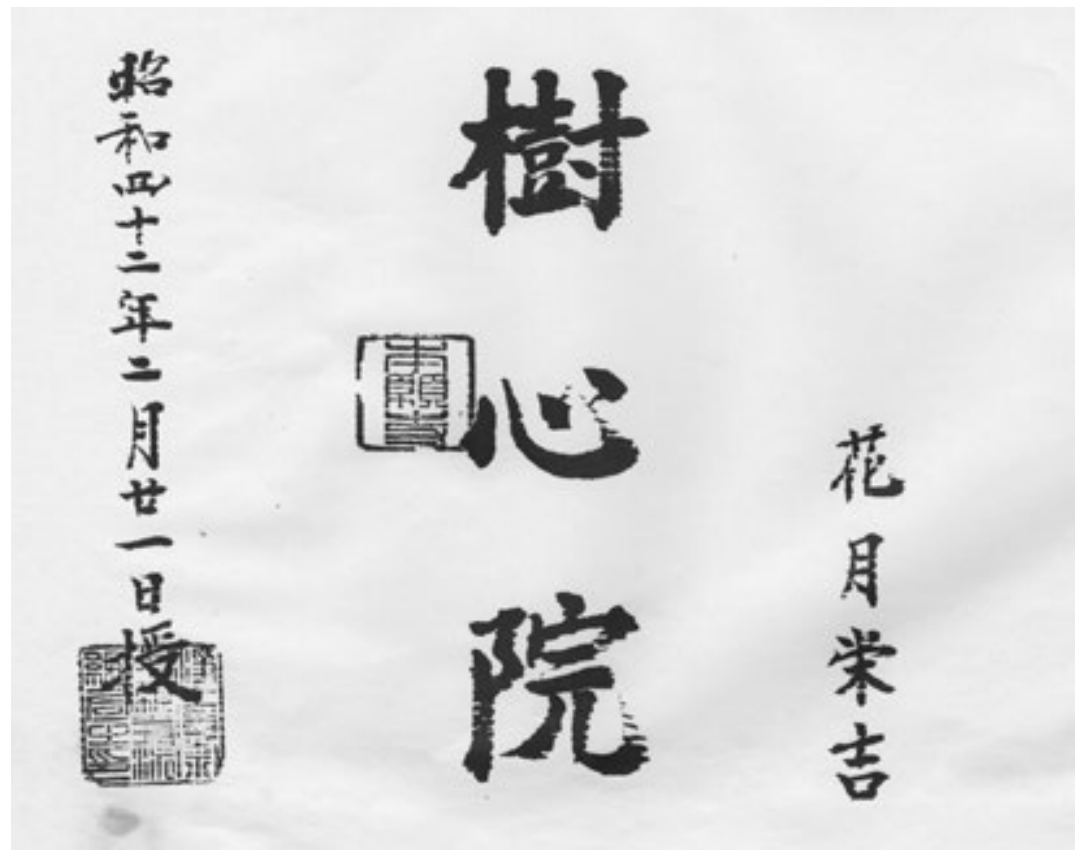

Ingō: Posthumous Title

February 21, 1967 (Showa 42)

Calligraphy written by Kosho Ohtani, the Lord Abbot of Nishi Honganji (Head Temple in Kyoto). InterpretationJushin In: Forest and Great Mind. The right column gives the Japanese characters for Kagetsu Eikichi.
Kagetsu was elected as the new president-a highly regarded office. ${ }^{7}$

\section{The Lord Abbot of Nishi Honganji}

When Kosho Ohtani became the new Lord Abbot (Gomonshu) of the Nishi Honganji, Kagetsu organized the ascension celebration that took place on April 30, 1933. President Kagetsu and the priests led the procession, followed by the children dressed in kimonos, from the Cordova Street Church to Dunlevy Street. From there they were driven to the Heaps Church. Over 1000 people attended this special service. Ritsu Ide was the master of ceremonies. A congratulatory message was given by President Kagetsu who then presented Certificates of Appreciation to three men who prepared the ceremony. A priest gave a Dharma sermon to end the service. Refreshments were served in the basement. ${ }^{8}$

My father had calligraphy written by Kosho Ohtani, the new Lord Abbot of Nishi Honganji. The first one was issued in a booklet by the Los Angeles Hompa Honganji to commemorate his visit- "The haves and have nots (real and spiritual worlds) divide the mind-Kosho." The second calligraphy written by Kosho Ohtani was presented to my father by Rev. Kenju Masuyama, who may have been a priest at the Nishi Honganji- "Wish for, ask for spiritual awakening in its entirety. Wholly will be fulfilled.-Kosho" This can be interpreted as, "If you wish (and work hard) to attain enlightenment, your wish can be wholly fulfilled." My father, on separate visits to the Nishi Honganji Temple, met Shojo Ohtani (the Lord Abbot's father) in 1934 and Kosho Ohtani, on October 27, 1952, as indicated by their signatures in his autograph book.

7 Ikuta, p. 66.

8 Ikuta, pp. 66-67. 


\section{Honouring the Dead}

In 1915 a wooden marker was erected to honour the Nikkei who had previously died. By 1934, the wood had deteriorated badly. The Bussei Renmei decided to replace it with a ten-foot high granite marker, paid from the savings they had accumulated and donations from the Nikkei population. ${ }^{9}$ On August 12, 1934, the Hompa Bukkyo Kai held an obon (memorial service for the dead) at the new granite monument. The priest read the okyo, (Buddhist sutra), and everybody participated in the burning of incense. The priest then gave a sermon, hymns were sung, and everyone walked up to the new stone monument to pray. ${ }^{10} \mathrm{Mr}$. Yasushi Ishii, Japanese Consul, and Church President Eikichi Kagetsu led the procession of priests and others who were present.

Another celebration called the hoyo started at $2 \mathrm{pm}$ at the altar inside the Church. Relatives of those who have passed away participated in the burning of incense. The Japanese Consul and Eikichi Kagetsu, Church President and President of the Canadian Japanese Association, along with representatives from over 20 organizations participated in the service. After the intermission, the Bukkyo Joshi Seinenkai (Buddhist women's youth association) and Bukkyo Fujinkai (Buddhist women's association) organized bon odori (a religious folk dance). ${ }^{11}$

\section{The New Hompa Temple and Chugakko}

At the February 24, 1934 regular board meeting, the following board members were elected:

$\begin{array}{ll}\text { President: } & \text { Eikichi Kagetsu } \\ \text { Vice Presidents: } & \text { Yaichi Horibe and Ritsu Ide } \\ \text { Treasurer: } & \text { Koichi Takahashi } \\ \text { Secretary: } & \text { Fukuzo Okano }\end{array}$

At an earlier, February 22 special board meeting, President Kagetsu proposed the formation of a Japanese Language Middle School_Chugakko-affiliated with the Canada Hompa Buddhist Church. President Kagetsu requested a fund drive be initiated for the building of the school. ${ }^{12}$ The Canada Hompa Chu Jogakko (Secondary School) was led by:

9 Ikuta, p. 75; Kawasaki, 1992, p. 3.

10 Tairiku Nippo, August 6, 1934; Kawasaki, p. 3.

11 Tairiku Nippo, August 6, 1934; De Garis 1950, pp. 60-61, 520-521.

12 Ikuta, pp. 71, 73. 

Principal:
Mr. Eikichi Kagetsu
Vice-Principal:
Director:
Rev. Seisho Ishiguro
Treasurer:

The school started in April, using the Cordova Buddhist Church Centre as a temporary location. Classes were held six days a week for two hours each evening. There were a total of nine teachers. In May, 1934, there were 65 students enrolled. ${ }^{13}$

When a new Japanese middle school building was proposed, the plans included a new church building, including classrooms for the school, located closer to the residences of the majority of its church members. This new plan was approved and the following building committee was named:

$\begin{array}{ll}\text { Chairman: } & \text { Ichitaro Suzuki } \\ \text { Vice Chairman: } & \text { Toichi Tsuruta } \\ \text { Treasurer: } & \text { Koichi Takahashi } \\ \text { Committee Members: } & \text { Eikichi Kagetsu, Yaichi Horibe, Ritsu Ide, } \\ & \text { Otokichi Shiomi, Shotaro Fukushima, } \\ & \text { Kyoji Suyama, and Fukuzo Okano. }\end{array}$

On August 15, the building committee bought two lots at the corner of East Cordova Street and Princess Avenue for $\$ 1,500$ and a grand ground breaking ceremony was held. The hall was built by several compatriot carpenters, with Takeichi Ono as head carpenter and Shotaro Fukushima as assistant head carpenter. President Kagetsu guaranteed the purchase of building materials. Donations amounting to $\$ 10,783.50$ were collected. The total construction cost was $\$ 15,200.00$. President Kagetsu covered the shortfall of $\$ 4,416.50$ which was to be repaid by future donations. ${ }^{14}$

The celebration for Buddha and the new building started at $1 \mathrm{pm}$ on Saturday, November 24 at the Heaps Temple. President Eikichi Kagetsu led the procession from the Heaps Church. The group included children in kimonos, a portable shrine, and representatives from other organizations. When the procession reached the new Hompa Church, the sacred image of the Buddha was placed on the altar. Music was followed by a speech by Eikichi Kagetsu. Everyone in attendance chanted Okyo, and the Revs. Kawasaki, Ishiguro, and Tada preached. Mr. Horibe gave an address to end the ceremony. The second 14 Ikuta, pp. 74,75 
The celebration continued the next day at noon with a parade led by Eikichi Kagetsu. It originated at the Kaikan (meeting hall) on Cordova and proceeded to the new church via Main and Powell. The ceremony included addresses by the Rev. Ishiguro and Rev. Kawasaki, chants by everyone, and gongyo (chant) by a priest. Celebratory speeches were given by President Eikichi Kagetsu, Committee Chairman Mr. Suzuki, and by representatives from 17 organizations. The treasurer, Mr. Takahashi, presented a report on the construction of the new building. Entertainment consisting of songs, dances, instrumental pieces (shamisen) was provided by individuals and youth groups. Approximately one thousand people participated in the celebrations. ${ }^{15}$ At the February 20, 1937 general board meeting, the board expressed their appreciation to Eikichi Kagetsu, principal promoter of the Buddhist Church and affiliated middle school, for his many financial contributions and meritorious services. ${ }^{16}$

On October 8, 1939, the Canada Hompa Buddhist Society celebrated its 35th anniversary with a special service. A procession led by President Eikichi Kagetsu and Vice-President Rinshichi Kuramitsu left the temple at 1pm and traveled west to Dunlevy Street, north to Powell Street, east to Princess Avenue, and south to the temple. There were 57 ochigosan (children) in colourful kimonos in the procession. ${ }^{17}$ Rinshichi Kuramitsu was the master of ceremonies. Buddhist church dignitaries included the Rev. Aoki (Kantoku of Canada Kyodan), Bishop R. Matsukage (Buddhist Churches of America), the Revs. Tachibana and Mitsubayashi (Hompa), Rev. Hirahara (Fairview), the Rev. Ikuta (New Westminster) and others. Chanting and offering of incense by representatives took place. The three surviving members from the 14 founding members in 1905 were presented with Certificates of Appreciation. Congratulatory messages from various parts of Canada, the US, and Japan were read. Bishop Matsukage gave a very emotional celebratory lecture and President Kagetsu thanked the Bishop. After the service, the ministers and representatives were served dinner at the Maruman Restaurant. The congregation gathered in the social hall downstairs for food and entertainment that lasted until 11pm that evening. ${ }^{18}$

The Buddhist Churches had a lively baseball league, the Bussei League. In 1940, the team from the Hompa Church nosed out their perennial rivals from the Fairview Church in a hotly contested game, with a 7 to 5 win in the best of three finals for the league championship. The Hompa team, known as the Yankees of the Bussei League, had their name engraved on the Kagetsu Trophy-emblematic of the League champion for the fifth consecutive year. ${ }^{19}$

As a student, Takashi Tsuji used to go to the Hompa church in Vancouver from his home in Mission City where there was no Buddhist temple, and where
15 Tairiku Nippo, November 21 and 26, 1934

16 Ikuta, p. 79.

17 The New Canadian, October, 13, 1939.

18 Ikuta, p. 82.

19 The New Canadian, August 28, 1940. 
20 Rev. Tsuji (Interview, May 26, 1998).

21 Watada, p. 101.

22 Rev. Tsuji (Interview, May 26, 1998).

23 The New Canadian, November 7, 1941. his father, Kamejiro Tsuji, was a lay minister. President Kagetsu was interested in young people and made it a point to converse with this young student. They talked about the future of the temple. After graduating from high school in Mission, Takashi studied at UBC for a year. ${ }^{20}$ Kamejiro wanted one of his four sons to become a Buddhist minister. Through the example of his father and visiting priests, Takashi decided to pursue that goal. In order to achieve this goal, however, he had to go to Japan. In 1938 he began his studies for the priesthood at Nishi Honganji Temple in Kyoto. He attended Japanese School in Mission City until grade 4. Thus, he was severely disadvantaged by his lack of Japanese reading and writing skills. With the help of fellow students and with self-determination he managed to complete the course work. After two years, he was ordained as a priest and was given the Buddhist name of Kenryu. ${ }^{21}$ In his third year in Japan, he pursued studies on Buddhism at Ryukoku University in Kyoto. The Dean, Bishop Masuyama, held services every morning. He used to call Tsuji into his office because his Japanese was weak. One day in October 1941, he called him in and said, "I want you to get out of Japan." Tsuji said, "I have three more months to finish my third year." The Bishop said, "I am not talking about finishing your course. I am talking about saving your life." Two or three days later Tsuji boarded a ship at Yokohama. His fellow students brought his belongings to him. When the ship arrived in Vancouver in early November, there was a large crowd waiting to see this brilliant student. Word had gotten around that Tsuji had finished a four-year course in three years. ${ }^{22}$

Four days later, a welcome banquet was held under the auspices of the Kaikyo Hombu (Buddhist Priests' Federation) for the Rev. Kenryu Tsuji. Almost 100 representatives from various Buddhist organizations and from many points on the lower mainland were in attendance. The Rev. Tsuji received words of welcome from various people, including Mr. E. Kagetsu, representing the Buddhist Church, the Rev. Tachibana, on behalf of the priesthood, Takeo Kitamura, for the League of Young People's Buddhist Associations, and Mr. Fujino of Mission. They expressed hope that the new priest would accomplish great works among the second generation. In a brief, but strong speech, the Rev. Tsuji thanked the gathering for honouring him, and pledged himself to work unceasingly for the cause of Buddhism among the Nisei. ${ }^{23}$

On Rev. Tsuji's return, Church President Kagetsu said, "You can't walk around like that." He took Tsuji to a men's clothing store to buy him a tuxedo. Tsuji told him that he would have no occasion to wear it. They settled on a black suit. The Rev. Tsuji described my father's Presidency as follows: ${ }^{24}$ 
Your father was the president of the Hompa church. During meetings, he listened to everybody. He was a good organizer and got things done. That is why they trusted him and worked with him. Your father was a man of a few words but a good leader.

\section{Personal Devotions}

My parents were devout Buddhists. When my grandmother Ei Nakamoto died in 1915 , an 82-year-old priest, probably a family friend, wrote a beautifully written long, comforting letter of condolence to my mother. When my sister Hideko died in 1938, Mr. Ryukichi Miyake, a family friend, wrote "Condolences on the death of Hideko" together with a poem of tribute "Hideko leaves this world calm and happy in the other world" in beautiful calligraphy.

My parents sent donations to their respective family temples in Japan. In 1929 a relative took donations to the temple where the priest said a prayer or okyo for each parent. The priest wrote a goma ofuda (elaborate note) that acknowledged the donor's name, the donor's age, the name of the temple and the donation. In 1939, similar donations were made in the names of Eikichi, Toyo, and Hideko. Prayers were also sent for my mother for her recovery from a serious illness. These documents were saved by my parents.

My father must have liked following Buddhist songs as he had copied them by hand. The first song was about having faith in Amida Buddha. The second song dealt with parenthood and was obviously composed in North America since it made references to Niseis (second generation) and Sanseis (third generation). Simply stated, the songs contain the following points:

- There is nothing as loveable as your child

- Education is not the only important thing. Teach them faith in God and Buddha

- Teach them about the future

- In action, even if people don't see, God and Buddha are watching

- Don't lie, do no wrong, don't neglect work, don't forget your ancestors

- Nurture your children, your grandchildren

- The compassion of parents is everlasting

- Don't forget to honour your obligation to parents. 
My father was an avid reader. The list of books in his library indicates that his favourite topic was Buddhism. He had three books on Kukai Kobo Daishi who founded the Shingon sect of Buddhism in the 9th century. ${ }^{25}$ Kukai Kobo Daishi established a monastic center on Koyasan, or Mt. Koya, which is located in the Wakayama Prefecture today. He was a saint who engaged in ascetic practices, a leading scholar of his time, and is believed to have invented the kana syllabary. He is also known as a poet, one of the three greatest calligraphers in Japanese history, and a lexicographer who compiled the oldest extant dictionary in Japan. ${ }^{26}$

My father had a well-known poem that was said to have been written by Kukai Kobo Daishi. Shuei, the priest who wrote the calligraphy on a shikishi (gilded cardboard), gave it to my father in the early spring of 1930. The calligrapher's trademark signature was not the Chinese characters used in standard Japanese (kanji). The poem is translated as follows:

A wandering monk is meditating alone in a grass hut in a quiet forest. At dawn, he hears the voices of the Three Treasures [Buddha, Dharma and Sangha]. He hears the voice of one bird, then another. Man-he has spirit. Voice and spirit. The monk then becomes convinced that man and nature are one and live together.

My father was interested in improving his own character. In his reading on Buddhism, he discovered ten levels of existence, which could also be used for guiding one's own life. He hand copied and labeled them "Ten Commandments." These ten items were: 1) Hell 2) Demon 3) Beast 4) Bloodshed 5) Humans 6) Ethereal Ideas 7) Glory Honour 8) Fine Arts 9) Buddhist Saint and 10) Buddha. My father started as an unknown country boy from Kishu. He was self-educated and self-motivated. As he advanced in life and in status, he developed his inner resources and his own character. As it is said, "selflessness elevates our selflessness to the level of art." My father was a selfless, generous, and unassuming man.

25 Miyazaki, 1928, [Ethical teachings of Kūkai]; Hosho, 1929, [A brief biography of Kūkai].

26 Kodansha, 1983, Vol. 4, p.304. 
TREE TRUNK - MY PILLOW I KAGETSU

104 
CHAPTER 11

\section{The Canadian Japanese Association in Action}

\section{Early Years}

F ormed in 1909, the Canadian Japanese Association (CJA) served the Japanese community well despite a rather turbulent beginning caused by rival factions in the CJA and the resulting organizational changes. ${ }^{1}$ The CJA played an instrumental role in the successful establishment of Japanese immigrants in Canada. It was a unified institution for Japanese immigrants, negotiating with government and civilian authorities to improve job opportunities and working conditions by opposing anti-Japanese restrictions. Over the years, it was recognized as the "spokesman" for the Japanese community. ${ }^{2}$

In 1920 a Constitution of the Canadian Japanese Association was written in English and registered with the Registrar of Companies. The Constitution provided for the election of not more than 45 Directors or Councilors from among the active members of the Association. The President, Vice-President and Treasurer and three Auditors were elected by the Directors. The Secretary was appointed by the President on approval by the Board of Directors, and was paid a salary. On January 24, 1923, the objectives were shortened to: "To effect the progress and advancement of Japanese residents in Canada and assimilate them."

In 1920, the BC government attempted to enforce an old law that would prevent people of Japanese ancestry from working in the logging industry. My 
father must have been impressed by the way the CJA handled the legal battle against the BC government. He decided to join the CJA and was elected a Director in $1921 .^{3}$ In the same year, a Democratic Reform Movement within the CJA, led by workers in the Japanese Labour Union and the farmers' associations who were dissatisfied with the CJA leadership, were successful in implementing reforms and in taking over the CJA. ${ }^{4}$

\section{A New President, Eikichi Kagetsu}

On February 1926, the Reform Group lost its majority on the executive board and my father was elected the new president. The key issue appeared to be the Japanese Consul's "authority to supervise all activities of the Japanese Association." An earlier interpretation understood this to apply only to activities related to the issuance of official documents on behalf of officials in Japan. At an emergency general meeting, the new executive board's agreement on the Consul's authority was ratified and sixteen members of the Reform Group resigned from the Board. Consul Kawai reported this outcome to the Minister of Foreign Affairs of Japan and added that "the new President is the owner of the biggest Japanese lumber mill, a very prudent man, who has been worried about the Japanese youth being Bolshevized." My father and many Isseis erroneously equated the labour movement with socialist and communist movements and worked with the Consul Tatsuo Kawai to subdue the movement. The Japanese Labour Union was isolated in the Japanese community and during the ensuing years lost many members and sympathizers. ${ }^{5}$

My father continued as President for four years until 1930 when he resigned as President, but continued as a Director. In 1934 he was again elected President of the CJA and continued in that position for two more years. In 1936 he took a two month tour of Europe, concentrated on the establishment of a new Japanese middle school, and the construction of the Hompa Buddhist Temple. He resumed the Presidency for the third time in 1937 and held that position for another four years. ${ }^{6}$ In 1941 Bunji Hisaoka was elected President. ${ }^{7}$ My father's logging business was suffering from the embargo that prohibited the export of logs to Japan. In addition, he was responsible for the operations of the Ocean Timber Company at Cowichan Lake. My father served as President for a total of ten years, longer than any other person.

The Canadian Japanese Association celebrated its 25th anniversary on Saturday, September 22, 1934 at the Japanese Hall. Five hundred people were
4 Sasaki, 1992, pp. 60-67. See also Tairiku Nippo Sha, 1924, pp. 60-66.

5 Sasaki, 1992, pp. 63-90.

6 Canadian Japanese Association, Eikichi Kagetsu Resume. For a list of CJA Presidents see Hatayama, 1940, p. 1040 and Appendix.

7 The New Canadian, February 24 \& March 13, 1941. 
in attendance for the two part ceremony. Vice-president Mr. Kiyoharu Momose was the Master of Ceremonies for the first part of the event. My father gave a welcoming speech followed by Consul Ishii who was the keynote speaker. Mr. Furukawa gave a history of the CJA. ${ }^{8}$ Certificates were given to nine persons, including my father who served as President of the CJA, three directors who served continuously for 10 years, four members who served continuously for 20 years, 24 individuals representing business organizations, and five to other organizations and Juichi Miyazaki of the Asahi Baseball Team. Giichi Nakayama was the Master of Ceremonies for the second part of the ceremonies that consisted of performers singing popular songs and playing Japanese musical instruments. A movie ended the festivities. Before the entertainment started my father hosted a reception held at the Fuji Chop Suey for 120 people. The party ended at $2 \mathrm{am}$.

By 1940, the CJA had a membership of over 4,000. The Nominating Committee drew up a slate of 70 candidates for the 35 positions on the Board of Directors and a slate of five candidates for the three auditor positions. The elections were similar to a municipal election. In Vancouver, five polling booths were set up, each one supervised by a director of the CJA. Other localities in the province, such as Ocean Falls, Woodfibre, Port Alice, and Fanny Bay, that had a large Japanese-Canadian population also had their own polls. ${ }^{9}$

\section{Sample Accomplishments of the CJA During the Kagetsu Presidency}

8 Tairiku Nippo, August 6, 1934.

9 Miyazaki, 1973, p. 15. See also The New Canadian, January 19, 1940.

10 Canadian Japanese Association (CJA), 1927.

11 Sato, 1969, p. 81.

12 CJA, Internal Report - Highlights.

13 CJA, Minutes, April 1934.

14 CJA, 1940a, Annual Report.
Examples of the types of work accomplished by the CJA under my father's Presidency are described below. Concerning education, the CJA in 1927 issued a report titled A Few Facts About Japanese School Children in Canada that contained excerpts from five articles published between 1922 and 1927 with test results that showed that the "Japanese are the most intelligent racial group resident in British Columbia." "The CJA sent Mr. Brown, Principal of Strathcona Public School, to Japan, ${ }^{11}$ donated $\$ 1,000$ towards the building of the Japanese Hall and School in 1928, studied the problem of how best to provide education to the Nisei, and to implement their findings. ${ }^{12}$

In 1934 the CJA assisted Dr. Shimotakahara, who gave health lectures to promote awareness of health matters, ${ }^{13}$ by raising $\$ 3,500$ for the Volunteer Federation fund drive, and provided funds to the Health Clinic to hire a full time nurse for home visits and home care for Japanese-Canadian patients. ${ }^{14}$ 
To strive for closer relations between Canadians and Japanese Canadians, the CJA sponsored a dinner in April 1929 with the presidents and managers of Caucasian companies that hired Japanese employees to chat about employment and wage problems. The CJA sent volunteers to help various public and charitable organizations to canvas the Japanese-Canadian districts to raise funds. ${ }^{15}$

As residents of Canada involved in the war between England and Germany/Italy, the CJA supported wholehearted cooperation of the war effort. With regards to the Canadian Conscription Law passed in 1940, the CJA decided that the Niseis should volunteer their services. For the registration of Canadian citizens in 1940, the CJA cooperated by setting up seven registration booths with Nisei interpreters for the benefit of Japanese Canadians. ${ }^{16}$ To maintain ties with Japan, the CJA gave guided tours to numerous student groups that visited Vancouver. To enlighten the Caucasian community on the Sino-Japanese incident, a special bulletin written in English was distributed in April $1937 .{ }^{17}$ The CJA sponsored a ceremony, in 1940, to commemorate the $3 \mathrm{rd}$ year of the "China Incident" at which Bunji Hisaoka, Eikichi Kagetsu, and Consul Nakauchi gave speeches. The Imperial birthday was celebrated on April 29, 1940 at the Japanese Hall where Chairman Kagetsu gave a speech. On October 9, 1940, a welcoming reception attended by 200 people was held for Mr. Yoshizawa, the newly appointed Minister to Canada at the Japanese Legation in Ottawa. Mr. Yoshizawa stated that he expects his Canadian compatriots to do their best for the country at their workplace. ${ }^{18}$

The CJA administered the "Certification" program authorized by the Japanese Consul, including the registration of birth, death, and marriage for the koseki tohon (family register) in Japan and travel certificates. ${ }^{19}$ To improve the economical standing of members, the CJA maintained an employment department to help workers from Japan find employment in Canada. Working with Dominion and provincial agricultural authorities, the CJA was able to promote exchange of views with Caucasian farmers on Vancouver Island and to join the BCFGA. ${ }^{20}$

At an executive meeting in 1940, Eikichi Kagetsu described the formation of two committees to study occupational possibilities in various fields for the Nisei, and to inquire into the entire question of improving the economic status of Japanese Canadians. ${ }^{21}$ Over 80 delegates representing 36 organizations pledged their support for a comprehensive survey of economic conditions among the Japanese in Canada at the annual conference. ${ }^{22}$

The CJA also compiled statistical data on the Japanese-Canadian population (adults, students, children and farmers) in Vancouver, with breakdowns of some of the data for the period between 1931 and 1932. A 1931 survey indicated
16 CJA, 1940a, Annual Report.

17 CJA, Internal Report - Highlights.

18 CJA, 1940a, Annual Report.

19 Continental Times, June 12, 1979. See also Miyazaki, 1973, p. 15.

20 CJA, Internal Report - Highlights. See also The New Canadian, April 12, 1940.

21 The New Canadian, February 29 \& May $15,1940$.

22 The New Canadian, May 29, 1940. 
that the fishermen of Japanese ancestry in Steveston held 2,283 licenses and caught 36,840 tons of salmon worth $\$ 948,480 .{ }^{23}$ A 56 page report, sponsored by the CJA, entitled Report of the Survey of the Second Generation Japanese in British Columbia presented the results of a house-to-house survey proposed by Rigenda Sumida and conducted by university students and graduates in 1935. The statistical data gave a comprehensive picture of the Nisei-population distribution, details of educational, occupational, marital, and social conditions. Unfortunately, analysis of the data and conclusions were not published. ${ }^{24}$

A detailed study, titled Survey of Japanese in Canada (in Japanese), was undertaken in 1938 to dispel propaganda by the anti-Japanese movement in Canada. Accurate information on the Japanese population in Canada helped the CJA organize a wide variety of activities. The total population of 23,000 was broken down by province, region, age, and occupation. ${ }^{25}$

The annual conference of Issei (first generation born in Japan) organizations in the province, held in October 1939 and presided by Eikichi Kagetsu, discussed among other topics, the vocational problems facing the Nisei (Second generation born in Canada). ${ }^{26}$ The CJA's Planning Committee studied employment opportunities of the Nisei in business. ${ }^{27}$ The CJA encouraged Niseis to join their ranks. In February 1940, three Niseis, Dr. M. Miyazaki, Edward T. Ouchi, and Nobuichi Yamaoka, were re-elected Directors of the CJA, and Eddie Kitagawa as one of the auditors. ${ }^{28}$ My father was a staunch advocate for Niseis to improve on their job opportunities and to assume greater responsibilities in the community. The CJA believed that conditions made it imperative that the organization should be strengthened to provide the stimulus and sponsored a "round table" conference of various Nisei organizations in Vancouver. ${ }^{29}$

23 CJA Internal Report - Highlights.

24 CJA, 1935, Report of the survey of the second generation Japanese in British Columbia.

25 CJA, 1938, Survey of Japanese in Canada

26 The New Canadian, October 13, 1939.

27 CJA, 1940a, Annual Report.

28 The New Canadian, February 2, 1940.

29 The New Canadian, April 12, 1940.

\section{The CJA Spearheaded Many Legal Challenges}

From the earliest days, Japanese Canadians in British Columbia were subjected to discriminatory laws and regulations that prohibited them from voting or from entering professions such as law and pharmacy. When jobs got scarce their participation in the lumber and fishing industries was threatened. In order to protect their rights and jobs, the CJA spearheaded many legal challenges.

The CJA responded quickly to combat anti-Japanese restrictions and statements by politicians. In February 1927, member E. P. Davis of Duncan City submitted a draft of a strong anti-Japanese bill to the BC legislature that prohibited Orientals from owning land, expelled Orientals from public schools in 
BC, and required compulsory English tests for Orientals engaged in dangerous work, which caused a majority of Japanese working in sawmills and logging camps to lose their jobs. The CJA dispatched Mr. Oliver, a lawyer with great influence in political matters, to Victoria where he was successful in getting the proposed law dropped. ${ }^{30}$ In addition, in August 1940 a letter of rebuttal written by the CJA's lawyer, Mr. Norris, was submitted to City council in response to Vancouver Council member Wilson's anti-Japanese slanderous remarks and on licensing restrictions. ${ }^{31}$

The number of licenses issued to the Japanese-Canadian fishermen reached a maximum of 3,267 or nearly one-half the total number issued in $1919 .{ }^{32}$ The Caucasian fishermen complained and based on the recommendations of a Royal Commission ${ }^{33}$ that looked into this problem, the Dominion Fisheries Department in 1923, made a 40\% reduction in Japanese-Canadian gill net licenses, a 25\% reduction in Japanese-Canadian trolling licenses and provided for other restrictions on fishing by the Japanese in Canada. ${ }^{34}$ These restrictions drove large numbers of Japanese Canadians out of the fisheries industry and caused great anxiety among the remaining fishermen.

When the number of fishing licenses issued to Japanese Canadians continued to decline, legal action was initiated after CJA President Kagetsu and Consul Kawai met to discuss the matter. ${ }^{35}$ As President of the CJA from 1926 through 1930, my father helped "to hurdle many obstacles." In December 1926, the Fishermen's Liaison Council with financial assistance from the CJA, appealed their case to the Supreme Court in Ottawa. ${ }^{36}$ On May 28, 1928, the Supreme Court ruled in favour of the Japanese-Canadian fishermen, and this decision was upheld on October 15, 1929 by the Privy Council. These judgments simply said that there was nothing in the Fisheries Act that gave the Minister of Fisheries the right to refuse a license to a duly qualified British subject. ${ }^{37}$

In 1929, before the decision of the Privy Council came down, the Dominion government passed an Order-in-Council that empowered the Minister of Fisheries to approve or deny the issuance of licenses. This essentially replaced and voided the rulings by the Supreme Court and Privy Council. However, the Dominion government discontinued its policy of reducing fishing licenses issue to Japanese fishermen in Canada. ${ }^{38}$
30 CJA Internal Report - Highlights.

31 CJA, 1940a, Annual Report.

32 Young, 1938, pp. 42-43. See also Scantland, 1984, pp. 25-27.

33 BC Fisheries Commission, 1922, p. 14.

34 Hidaka, 1942, p. 18.

35 CJA Internal Report - Fishing Problems; Scantland, pp. 25-27.

36 CJA Internal Report - Fishing Problems. See also Hidaka, p 21.

37 Supreme Court of Canada, In the matter of a Reference as to the Constitutional Validity of Certain Sections of the Fisheries Act 1914, [1928] SCR. 457; Privy Council, Attorney-General for Canada, Appellant, and Attorney-General for British Columbia and Others, Respondents, [1930] AC 111.

38 Hidaka, pp. 21-22. 


\section{CHAPTER 12 \\ Other Activities in the Community}

\section{Japanese Newspapers}

1 Nakayama, [Encyclopaedia of the Japanese in Canada: Supplement], 1922, pp. 31-32.

2 Gonnami, Tsuneharu, Tairiku Nippo [The Continental Daily News] 1908-1941 (Microfilm Review, 18(1), Winter, 1989), pp. 38-40. They published A History of Japanese in Canada Part 1 in 1909, Part 2 in 1917 and Part 3 in 1924 and a Directory of Japanese in Canada in 1926 and 1941.

3 Gonnami, Tsuneharu, Kanada Shimbun Shimbun [The Canada Daily News] and Nikkan Minshu [The Daily People] for 1941 on Microfilm: A Preservation Microfilming Project at the University of British Columbia Library (Microfilm Review, 24(3), Summer 1995), pp.117123. n 1918, noted Japanese-Canadian historian Jinshiro Nakayama wrote: ${ }^{1}$

Recently, a young enterprising businessman suddenly appeared like a comet onto the Vancouver Japanese community. His energetic activities have caught the eyes of the community. This person is Eikichi Kagetsu. - To write a biography of Eikichi Kagetsu is like looking up in awe at an appearance of a new star.

The first newspaper, Bankuba Shuho, for Japanese Canadians was established in Vancouver in 1887 by a Japanese Methodist minister. In 1903, the name was changed to Kanada Shinpo. In 1907, about a year after my father arrived in Canada, Tairiku Nippo (The Continental Daily News) was published daily. ${ }^{2}$ In 1924, a daily newspaper called Nikkan Minshu (The Daily People) replaced a weekly put out by the Kanada Nihonjin Rodo Kumiai (Japanese Workers Union). ${ }^{3}$

The Issei mistakenly equated unionism with "red menace" or "Communism." My father was one of them and he wanted to protect the 
Japanese public from this "menace." That was why in 1923, a conservative newspaper called Kanada Shinbun (Canada Daily News) was founded by Juzo Suzuki, a scholarly gentleman. My father was a good friend and provided financial backing. ${ }^{4}$ In October 1930, the Canada Daily News Publishing Company (CDNP) purchased a used rotary press capable of printing and folding an 8-page newspaper at the speed of 3,000 per hour for \$3,300.00. In July 1935, the CDNP transferred ownership of the printing press to Koji Nakatsuka and Eikichi Kagetsu. My father assumed the payments for the \$1100.oo owed to the Duplex Printing Press Company. ${ }^{5}$

The Tairiku Nippo, Kanada Shimbun and Nikkan Minshu published a mixture of articles on daily social and political events in Japanese communities in BC and current news from Japan. Juzo Suzuki was considered one of the best journalists among the ethnic press in Vancouver. He gave more coverage to local Japanese-Canadian news including church news than the other two Japanese-language papers. In 1941, the Tairiku Nippo had a circulation of about 4,000, Kanada Shimbun 2,500 and Nikkan Minshu 1,500. These circulation numbers indicate that many families were subscribing to more than one paper. In 1932, a six-page Japanese-Canadian newspaper in English called the New Age was started but folded after only one year. In 1936, the Japanese Canadian was published in English, but it too was short-lived. ${ }^{6}$

Edward Takeshi Ouchi (UBC '37) and the Japanese Consul, Hirokichi Nemichi discussed the subject of publishing a Japanese-Canadian newspaper, a topic discussed by Shinobu Higashi (UBC'38) and others as well. The Japanese Consul, who wielded a certain amount of stature within the Japanese community, organized a meeting at which Messrs. Eikichi Kagetsu, Etsuji Morii, Usaburo Nishikawa, and Edward Ouchi agreed to fund this worthwhile project. ${ }^{7}$ Dr. Masajiro Miyazaki held a meeting that endorsed the idea of using Taiyo Printers, since they did not have enough work, to publish the new Japanese-Canadian newspaper in English called The New Canadian. ${ }^{8}$ Another important person involved in The New Canadian was Shinobu Higashi, who had some experience writing for Ubyssey, UBC's student newspaper.

Tom Shoyama had saved three hundred dollars working in a paper mill in Woodfibre. He received a phone call from Shinobu Higashi asking him to come to Vancouver for the Christmas holidays and to bring his typewriter and whatever funds he had. Shoyama joined the group that was going to start the newspaper in a one-room office above Taiyo Printers. The first edition was published on November 24, 1938. Due to lack of funds, the second edition wasn't printed until December 29, 1938. In February of the following year it became a weekly paper.
4 The Kagetsu \& Co. ledger shows monthly payments ranging from $\$ 37.50$ to $\$ 50.00$ totaling $\$ 745.50$ from November 1930 through April 1932. Part of this loan was repaid over the next few years.

5 Deed of Assignment, July 5, 1935; The New Canadian, September 23, 1999.

6 Tom Shoyama (Interview, September 11, 1998); Adachi, 1976, p. 159.

7 Roy Kawamoto (Interview with Edward Takeshi Ouchi, n.d.).

8 Miyazaki, 1973, p. 13. 
Shinobu Higashi was the first editor, but left after three months to take a newspaper position in Manchuria. Tom Shoyama then became the editor and Shinobu Higashi's brother, Yoshimitsu, helped him publish the newspaper. Ed Ouchi who knew everyone in the community, especially the more influential Issei, was the man who led the fund-raising drive. My father's name was at the top of the list of donors. ${ }^{9}$ The circulation of The New Canadian grew to about 1500 by 1941 .

\section{Saisei Kai}

My father was instrumental in forming the Showa Foundation, which provided funds for dealing with discriminatory anti-Japanese problems. They had $\$ 2,607.23$ of which the Japanese Government donated $\$ 1,446$.00. The CJA donated $\$ 55.00$ to the Foundation. It was decided that the interest earned be used for projects related to the Nisei. ${ }^{10}$

To commemorate the birth of the Crown Prince in 1934, the Imperial Household Ministry bestowed an Imperial Grant of 5000 yen, from His Imperial Majesty the Emperor of Japan, to each prominent organization overseas for community projects. The CJA gratefully received this grant and to comply with the Imperial wish, my father as President of the CJA organized Onshikinen Saisei Kai (The Imperial Grant Memorial Social Welfare Society). The CJA also solicited donations from supporters. ${ }^{11}$ During 1934, meetings were held to discuss the goals of the Saisei Kai, with input from the CJA and member

9 The New Canadian, September 8, 1939, Insert.

10 The New Canadian, March 3, 1960, Japanese Section.

11 Continental Times, June 12, 1979.

12 Canadian Japanese Association, Minutes, April 1934.

13 Canadian Japanese Association, Annual Report 1937.

14 Canadian Japanese Association, Annual Report 1940. See Chapter 15. organizations in BC. ${ }^{12}$

In 1937, the Saisei Kai held a joint meeting with the Showa Foundation and decided to amalgamate voluntarily as the goals of both groups were similar. The combined group retained Saisei Kai as its name. Also, they decided to purchase $\$ 8,000$ in Japanese government bonds with the combined funds. Kagetsu and Morii each donated $\$ 100$ towards the purchase of these bonds. ${ }^{13}$ In 1940, at a meeting of representatives, a resolution was passed to start a fund raising campaign to commemorate the year 2600 in the Japanese Imperial calendar. ${ }^{14}$ 


\section{Fighting Tuberculosis}

The Asian population in Vancouver had a much higher mortality rate from tuberculosis (TB) than the other races. A Japanese clinic opened in 1932 in response to the increasing number of TB cases among the Japanese. Mrs. H. (Toshiko) Hyodo of the Powell United Church led this effort, assisted by Fumiko Komiyama, Nobuko Shimotakahara, and Miss Florence Bird, with support from twelve Japanese women's groups. Initially, two Japanese doctors, Dr. Kozoi Shimotakahara and Dr. Matasaburo Uchida, donated their services as did members from the Victorian Order of Nurses. Initial operations were difficult due to temporary quarters and lack of funds.

After 1934, the clinic began to receive funds from the Japanese division of the Vancouver Welfare Association which consisted of 41 organizations that carried out social services in Vancouver. In May of 1935, the United Church's Oriental Hospital was vacated and designated for the sole use of the clinic. ${ }^{15}$

In addition to its primary function as a TB clinic, the free clinic provided medical examinations, shots for small pox and diphtheria, prenatal care, and health education for the Japanese-Canadian community. By 1939, four Japanese-Canadian doctors donated their services and Ruth Akagawa R.N., the first Japanese woman in Canada to become a member of the Victorian Order of Nurses, attended to patients at the clinic and at their homes. That year, my father donated a portable X-ray machine which was of incalculable value in administering medical examinations and in controlling TB. ${ }^{16} \mathrm{Dr}$. Shimotakahara, our family doctor, brought the portable X-ray unit to our home and the family was checked.

It is not clear how long my father was President of the Japanese division of the Vancouver Welfare Federation. According to The New Canadian's records, he was President during 1939 and 1940. ${ }^{17}$ The CJA helped organize the annual fund raising campaign. Thanks to the dedicated efforts of many Japanese Canadians, a fairly high standard of public health services was provided by the clinic.

\section{Japanese Canadian Citizens' League}

Many of the young Niseis knew that my father took a special interest in them and wanted them to begin to assume leadership roles in the Japanese commu-

15 Sasaki, 1992, pp. 92-99.

16 The New Canadian, May 27, 1939.

17 The New Canadian, October 20, 1939; March 29, 1940. 
18 Adachi, p. 164: date 1932; Ito, 1994, p 180: date 1935.

19 Saita, 1884-1975.

20 The Minutes of the Vancouver Chapter of the Japanese Canadian Citizens' League Executive Meetings, February 17, March 4 and meeting at the Consul's residence March 5, 1936.

21 The New Canadian, November 3, 1939. nity. He often expressed these sentiments at home especially to Hajime, his oldest son. It was probably while he was President that the CJA recognized that the Nisei were maturing and established the Seinen Rouraku Kyogi Kai (youth council) within the Association.

Around 1934, the CJA sponsored a rally to organize some form of Nisei organization to lead Japanese Canadians to become better citizens of Canada. ${ }^{18}$ The Japanese Hall auditorium was filled with members of many Nisei organizations and included all of the Japanese language newspapers. Professor Henry Angus from UBC, Mr. Brown, Principal of Stathcona High School, and others including some Issei leaders spoke.

Twenty Niseis were chosen by the audience to spearhead this effort. Dr. H. S. Saita was elected President together with four other officers and 15 councilors. The organization was named the Japanese Canadian Citizens Association (JCCA) and devoted its effort to educating the public by sponsoring meetings once a month with experienced speakers and with discussions by members. ${ }^{19}$ Due to apathy and indifference by the majority of Niseis, the JCCA never took hold. However, a 1935 survey of Japanese Canadians in British Columbia still indicated a need for an effective group for the Niseis. Prominent members of the JCCA and others worked towards forming a federation of Nisei groups. They drew up a Constitution and nominated candidates for the officers. At a meeting on February 13, 1936, the JCCA was dissolved and the formation of the new Japanese Canadian Citizen's League (JCCL) was approved with an amended Constitution. An election of officers followed and Mr. Harry Naganobu was elected the new President. The goal was to form chapters at other locations.

At the third Executive meeting held on March 4, it was announced that the principal Japanese representative in Vancouver would be briefed on the JCCL. The Japanese Consul Hon. Ko Ishii who apparently was consulted on the matter, had a meeting at his residence. Eikichi Kagetsu, who had declined the Presidency of the CJA in 1936 because of his trip to Europe, was on the guest list along with seven others. At the meeting, Mr. N. Yamaoka explained the organization of the JCCL, its purpose, its achievements to date, and future programming options. The Isseis stated that they were willing to support the Niseis financially if needed. ${ }^{20}$

The JCCL held a National Oratorical Contest during its National Conventions in 1938. The Japanese Consul in Vancouver, Hirokichi Nemichi, donated a handsome challenge trophy for the national champion. Another challenge trophy was donated by Mr. Eikichi Kagetsu for the Vancouver Island regional contest, and a similar trophy was donated by Mr. B. Hisaoka for the Mainland contest. ${ }^{21}$ In 1939, Marion Yoneda was awarded the Kagetsu Island 
Challenge Trophy for best speaker competing in the Vancouver Island semifinals JCCL Oratorical Contest. Her speech titled "The Nisei Task" described racial discrimination and how the Nisei should combat it. ${ }^{22}$

\section{Wakayama Kenjinkai}

It was common practice for Japanese from a particular prefecture in Japan to form their own kenjinkai or prefectural club. There is no record of my father's participation in the leadership of the Wakayama Kenjinkai. Even so, he must have been active in this group because it included many of his friends. The Wakayama Kenjinkai held an annual daylong picnic during the summer at Second Beach near the Spanish Banks. Our whole family used to attend the picnic. Each family staked out a space and spread out the food they brought. There was always a lot of Japanese food and even sandwiches. There were race competitions such as the dash, three-legged race, sack race, etc., for the different age groups. The women joined the race where the runner carried an egg on a spoon. If the egg fell off, you lost time picking it up. The men raced around a "track" on the beach. There were prizes for the winners. A favorite game involved a watermelon. Each player in turn was blindfolded, given a thick stick to hold with both hands, was turned around a few times to disorient them, and then faced toward a watermelon on a stand. The objective was to guess the location of the watermelon and to slam the stick down trying to hit the watermelon. It was fun to watch the participant's face as he pulled off the blindfold. His expression exclaimed "How could I miss it by so much!" If the player hit or smashed the watermelon, he won it.

\section{Nikka Trade Association}

In October, 1940, the Nikka (Japan-Canada) Trade Association held its first general meeting at the Nippon Club. My father was elected President and Kesahiro Iwashita the Chairman of the Board of Directors. This group was made up of prominent businessmen in Vancouver. ${ }^{23}$ 


\section{Philanthropy}

My sister Kimiyo recalled that our father was not extravagant in his lifestyle. For example, my father reluctantly gave my mother additional money for household expenses when needed. My mother had to be frugal to make ends meet. She would go to the wholesaler for work clothes and look for bargains. My father shunned ostentation and dressed conservatively. He gave much of his time, talents, and money to the Japanese-Canadian communities he was associated with. Charities of all types benefited from his generosity. "He gave generous support to the cultural and educational activities and contributed to the economic welfare of the Japanese Canadians." ${ }^{24}$

A family friend observed: $:^{25}$
Many in Mr. Kagetsu's position are involved in local organizations that in most cases are interested in financial support. I don't think he received proper or enough credit for it. Your dad did an awful lot for people. His position was not easy to carry out. He had to be so diplomatic.

We have already seen that as early as 1911, he was recognized for his dedication and support for the construction of the new Heaps Buddhist Church. ${ }^{26}$ In 1937, he received a citation for his many financial contributions and meritorious service to the new Hompa Buddhist Temple and associated Middle School. ${ }^{27} \mathrm{He}$ also donated to Christian ministers who presented him with books they had written in appreciation for his financial support.

One writer wrote, "The President of the Hompa Church was expected to

24 Continental Times, January 1, 1976

25 Kay (Hatashita) Hayashi (Interview, August 1999).

26 Ikuta, 1981, pp. 25-26.

27 Ikuta, p. 79.

28 Watada, 1996, p. 76.

29 Mayor Gerald G McGeer (Letter to Eikichi Kagetsu, July 4, 1935).

30 The New Canadian, November, 24, 1939. pay for food and drinks at meetings and key gatherings." ${ }^{28}$ It was his generous nature that he treated committees and workers of the organizations he led to dinner and hosted receptions on special occasions. As a member of the CJA Executive Board since 1920 and later as President for ten years (not consecutively), my father donated generously to the many campaigns sponsored by the CJA.

In 1935, the City of Vancouver sold bonds to finance a new City Hall. The Mayor, Gerald G. McGeer, wrote to my father, "Your generous co-operation has helped to crown this effort with success. ... I wish to extend to you my very sincere and heart-felt thanks." ${ }^{29}$ In November 1939, the Japanese Consul and my father were listed as the top contributors to the Canadian War Chest Drive. ${ }^{30}$ He provided financial support for the education of several promising 
students. He sent monthly cheques to Chikao Hori who graduated with a Doctor of Medicine degree from Rush Medical College, University of Chicago. ${ }^{31}$ The parents of another student never told their son that he received financial aid from my father. Also, many students from Japan were sponsored by him. Repayment was never expected. To hear that they were successful in whatever field they chose was compensation enough for him.

My father also donated to the disaster fund for the flood in Wakayama Prefecture and to the Japanese War Veterans organization. He received a book that described the flood and war conditions from each group. He received two certificates of appreciation for contributions to the Meiji Shrine Renovation. He donated to Buddhist Temples in Japan. An artist named Sekido sent my father a wall hanging that he had painted in appreciation of his support.

A writer wrote that one could learn much about a person by looking at his cheque book. Even without cheque book stubs, my father was well known for his benevolence. A friend who was down on their luck was never refused. $\mathrm{He}$ helped start several small businesses or saved them from bankruptcy, but did not count on being repaid. Since he was such an honest person, he trusted all and would say, "If he were able, he would not forget his indebtedness."

Many of the loans were recorded in ledgers as "Temporary Loans" for Kagetsu \& Co. and for Deep Bay Logging Company and in a little "black" book that listed other loans. When the unrepaid loans between 1925 through 1939 were tabulated, the total for fifteen years was approximately $\$ 40,000$ or an average of $\$ 2,600$ per year. During that period, $\$ 1,000$ was considered a good annual salary.

My father was a very generous man, a great philanthropist. 
CHAPTER 13

\section{Participation in Memorable Events}

1 Vancouver Daily Province, June 20, 23, 1914; Tairiku Nippo, June 20, 1914.

3 Rinshu ko tai kinen, [Commemorating 41st Expedition of Training Vessels] (Editorial Committee for Training Ships, 1914); Rinshu kantai enko kinen [Commemorating Distant Expeditions of Training Vessels] (Editorial Committee for Training Ships, 1917). These books were not for sale.

4 Vancouver Daily Province, February 3, 1925.

5 Vancouver Daily Province, February 6, 1925; Takata, 1983, see photo p. 42 (Year should be 1925).

\section{Navy Visits}

O n June 20, 1914, His Imperial Japanese Majesty's training squadron, the Asama and Azuma, arrived in Vancouver, ${ }^{1}$ and three years later the warships Tokiwa and Yakumo came. ${ }^{2}$ My father probably participated in the festivities. The Japanese Consul in Vancouver presented him with a copy of the commemorative books that were prepared for these two trips. ${ }^{3}$

In February 1925, three war-scarred cruisers, the Asama, Yakumo and Izumo, then training ships of the Japanese Navy, arrived in Vancouver on the last leg of their 20,000-mile cruise. A representative of the Canadian government welcomed the officers and men of the squadron, by stating in part: ${ }^{4}$

We have nothing but admiration for the efficient manner in which Japan has developed her naval strength and we are grateful for the friendly attitude which the Japanese Government has always taken in regard to questions affecting the mutual interests of Japan and the British Empire.

The Japanese residents of the province came from every part of British Columbia to take part in greeting their countrymen. ${ }^{5}$ 
A tragedy occurred when a naval launch, on its way back to the cruiser Izumo, collided with a barge pulled by a tugboat and eleven men were lost. The Buddhist Church in Vancouver was asked to conduct an appropriate service on board the Izumo on February 9. Consul Isago Gomyo and representatives of 33 Japanese-Canadian organizations, including my father, were present. On February 15, a memorial service in honour of the lost sailors took place at the church. Nearly 400 people representing various organizations within the community and sympathetic mourners attended. My father as President of the Hompa Buddhist Church gave the opening address. Consul Gomyo and representatives of various organizations expressed words of condolence before offering incense. ${ }^{6}$

Consul and Madame Isago Gomyo held a reception at Hotel Vancouver in honour of Vice-Admiral Saburo Hyakutake and officers of the visiting Japanese navy training squadron - there was a feeling of sympathy, good fellowship, and a spirit of mutual understanding and respect. ${ }^{7}$

In August 1929, the cruisers Asama and Iwate, under the command of ViceAdmiral K. Nomura, arrived in Vancouver after visiting Victoria and Puget Sound. At the mouth of the Fraser River, hundreds of Japanese fishing boats, crowded with not only the families of the fishermen themselves, but countless guests from Vancouver, welcomed the ships. ${ }^{8}$ Hon. T. Fukuma, Japanese Consul for Western Canada, and the welcoming committee representatives-my father, Oki, Yamamoto, and Takeuchi-paid a formal call on Vice-Admiral K. Nomura, the commander-in-chief of the squadron, on board the Asama. ${ }^{9}$ Later, Mayor W. H. Malkin called on the Vice-Admiral to present the respects of the city. The Vice-Admiral reciprocated the formality by visiting the Mayor at his office. He also called on the Consul at his residence, and from there he went to Stanley Park where he laid a wreath on the Japanese War Memorial, the Cenotaph, to pay his respects. ${ }^{10}$

The officers, midshipmen, and sailors were taken sightseeing; a reception was held on the warships; the Mayor held a civic dinner; the Japanese consul, Hon. T. Fukuma held a reception and ball that was attended by civic and governmental dignitaries including the Hon. R. Randolph Bruce, LieutenantGovernor. ${ }^{11}$ On Sunday the ships were open for inspection and all day long crowds of Japanese went aboard to visit the officers and sailors and took them presents. In the afternoon, another large crowd gathered to hear the naval band in a concert at Stanley Park. Early the next morning, the cruisers Asama and Iwate sailed out the Lion's Gate and proceeded out to sea. The next port of call was San Francisco. They travelled close to 25,000 miles before returning to their home base at Yokosuka. ${ }^{12}$
6 Ikuta, 1981, p. 51; Watada, 1996, p. 68.

7 Vancouver Daily Province, February 10, 1925.

8 Vancouver Daily Province, August 10, 1929; Tanaka, 1990, see photo p. 30.

9 Tairiku Nippo, August 10, 1929.

10 Vancouver Daily Province, August 9, 10, 1929.

11 Vancouver Daily Province, August 10, 1929.

12 Vancouver Daily Province, August 12, 1929. 
My father invited Vice-Admiral Nomura to our home during his visit to Vancouver. Admiral Nomura was from the same prefecture, Wakayama, as my father and so they got along well. My father presented him with a gift, probably a "cougar" throw rug. He received a postcard from Vice-Admiral Nomura:

\section{August 15th, aboard the "Asama" in San Francisco}

Dear Mr. Kagetsu. My fleet and I are very grateful for the heartwarming welcome you gave us the other day and I wish to thank you and all very much. On the personal level, I wish to thank you for the fine gift that was presented to me. Although uneasy at first, I have decided to accept your thoughtful kindness. Also should you sail for Tokyo or Wakayama in the future, please drop by my office or home. I would like to welcome you with humility and sincerity. Please give my regards to your wife. Wishing you good health and increased prosperity.

I am, yours truly, Kichizaburo Nomura

In April, 1933, the Japanese cruisers Yakumo and Iwate arrived in Vancouver for a three-day official visit. As during the other visits, the Mayor of Vancouver and the Vice Admiral exchanged formalities, and the Vice Admiral placed a wreath at the Cenotaph, the Japanese War Memorial in Stanley Park. ${ }^{13}$ Vice Admiral Gengo Hyakutake and officers of the two Japanese training ships were invited to dinner at the Hotel Vancouver where representatives of the various branches of civic life joined to welcome the Japanese visitors. ${ }^{14}$

On Thursday, the personnel were "at home" on the flagship from $3 \mathrm{pm}$ to $5 \mathrm{pm}$ and at $7 \mathrm{pm}$ the commander-in-chief hosted a dinner on board the vessel. Mr. M. Nomomura, acting Consul for Japan and Mrs. Nomomura held a reception in honour of Vice-Admiral Gengo Hyakutake, officers, and cadets of the visiting Japanese squadron. ${ }^{15}$ My father gave British Columbia apples to the crew and received a letter of appreciation from Vice-Admiral Gengo Hyakutake. Many thousands of guests visited the two ships during their stay. The squadron returned to their home base after four and a half months. ${ }^{16}$

As President of the CJA, my father was active in the planning and in the actual welcoming of the training squadrons from Japan. On each occasion, the CJA hosted a reception for the Fleet with funds raised through donations. ${ }^{17}$ My father mentioned to friends that he toured the bridge and other parts of the ship that were not shown to others. 


\section{Certificate of Commendation by the Japan Industrial Association}

Beginning in 1924, the Japan Industrial Association honoured those who gave meritorious service to industry and foreign trade. On November 30, 1929, His Imperial Highness, Prince Hiroyasu, brother of the Emperor, personally presented Certificates of Commendation to the individuals honoured at a ceremony attended by four Ministers and by some one hundred prominent businessmen from all fields. Honorary President, Prince Hiroyasu, stated in part:

Prosperity of this nation is very dependent on development of industry and foreign trade.... Internally, there are many complex problems regarding resources, production, financing, consumption, labour, etc., that may lead to depression in the economic world. Externally, international economic competition is becoming more intense and is adversely affecting foreign trade.... Today, as we record your past achievements at this ceremony, we hope that you will continue to exert your energies in developing national prosperity.

Of the 64 honourees, my father, president of the CJA (Nihonjinkai), and Mr. Rikimatsu Tabata, proprietor of Tabata Shokai (Trading Co.) were the only overseas individuals, and the first ones from Vancouver to be honoured. ${ }^{18}$ On the same day, at a ceremony at the Japanese Consul's residence in Vancouver, Consul Toyokichi Fukuma presented these two men their "Certificate of Commendation" from the Japan Industrial Association. ${ }^{19}$ The translated citation on my father's Certificate read:

To whom it may Concern: Mr. Eikichi Kagetsu of Wakayama Ken early went abroad to Vancouver, Canada and has strenuously engaged in logging enterprises with such zeal as to contribute towards the advancement of our national fortune. Also, he has devoted himself to the guidance and leadership of our countrymen for many years and is now deserving of being considered as a model for others. We hereby duly recognize his distinguished services and ensuing merit.

His Imperial Highness Prince Hiroyasu, Honorary President of the Japan Industrial Association,
18 Unidentified newspaper clipping in Japanese.

19 Continental Times, January 27, 1976; Takata, p. 85 


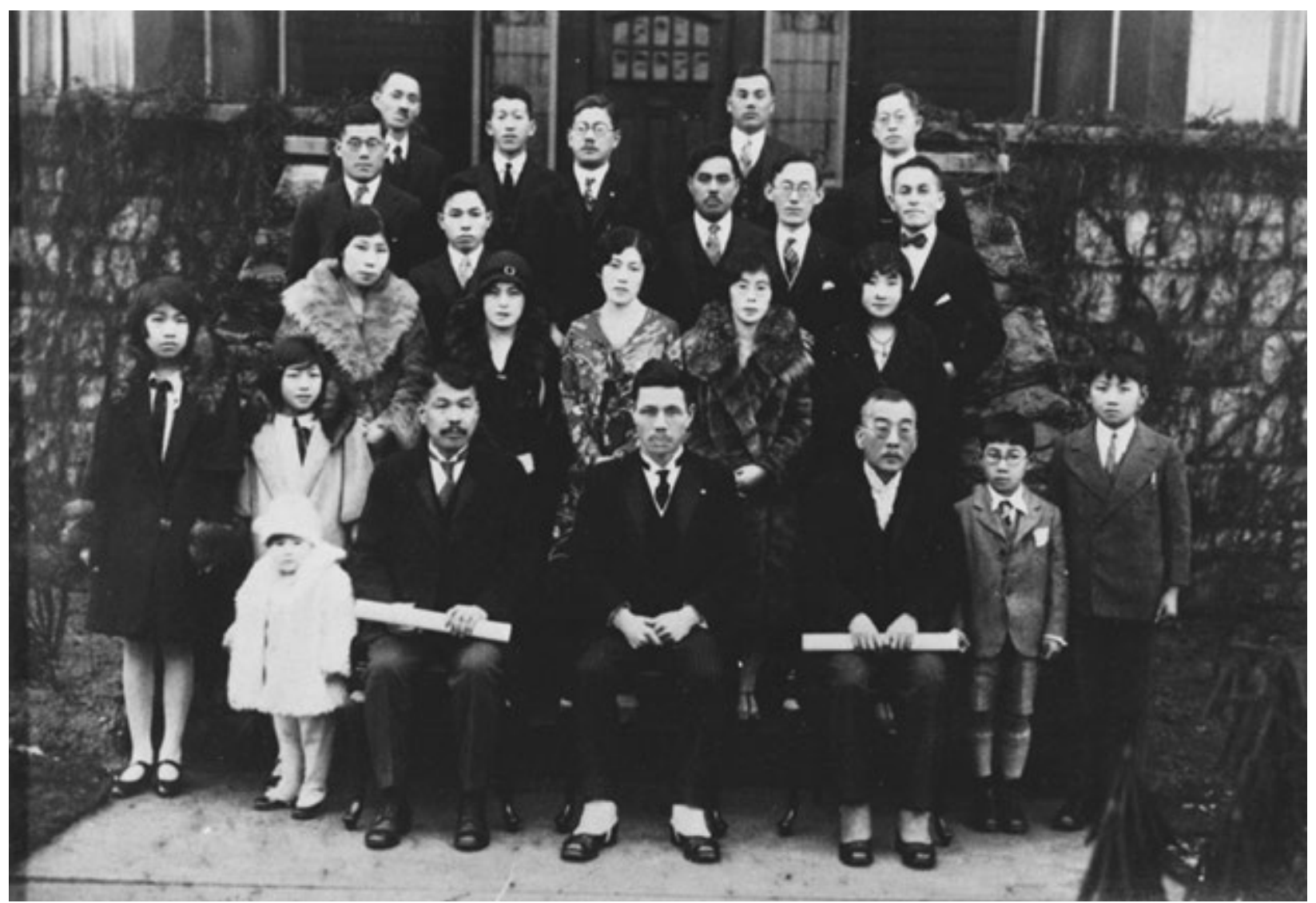

Presentation of Certificate of

Commendation by the Japan Industrial Association on November 30, 1929 to Eikichi Kagetsu and Rikimatsu Tabata by Japanese Consul Toyokichi Fukuma (front row centre).
Grand Cordon of the Supreme Order of the Chrysanthemum and the Fifth Class of the Military Order of the Golden Kite,

Nakaji Kajiwara, President of Japan Industrial Association, Shorokui and Fifth Class of the Order of the Sacred Treasure. 


\section{Institute of Pacific Relations Conference}

Inazo Nitobe's life work was summarized as follows: ${ }^{20}$

Student at Japanese, American, and German Universities, teacher in universities of Japan, first exchange professor to the United States of America, expert adviser to the Japanese Government, member of the Japanese House of Peers for six years and Under Secretary General of the League of Nations ... apostle of international goodwill.

In 1926 Inazo Nitobe became chairman of the Japan Council of the Institute of Pacific Relations. In this capacity, he led the Japanese delegation to the 1933 conference of the Institute in Banff, Alberta. On his way to Banff, he stopped in Vancouver and met my father. Nitobe encouraged my father to attend and support the conference. My father decided to attend the fifth biennial conference, the first to be held in North America, with my mother, Hideko, Kimiyo, Hajime, and Takako.

Representatives of ten nations were assembled in Banff for friendly discussions on a score of diverse issues-economic, political, and cultural-affecting the countries bordering the Pacific. ${ }^{21}$ Even though the conference leaders tried to avoid direct discussion of the "Manchurian Issue" between the Japanese and Chinese delegates, a spirited debate opened up. Japan's population was growing at the rate of more than one million a year. Manchuria was needed not only as a source of raw materials, but also as a market for its goods and a place for its excess population. The Chinese stated that their population was growing at the rate of 4 million a year and their claims to Manchuria to settle emigrants were much stronger and urgent than the claims by the Japanese. Other spokesmen suggested that there was room for both countries in Manchuria. ${ }^{22}$

My father had opportunities to chat with delegates from different countries. Many of them signed his autograph book. In the evening, there was dancing in the ballroom. Hideko danced with a very gallant Harvard-educated Japanese delegate, Kenzo Takayanagi, who became the leading constitutional lawyer in Japan. During the US occupation of Japan, he coordinated the Japanese scholars who rewrote the Japanese constitution for General MacArthur.

Dr. Inazo Nitobe died at Victoria in 1933 while on his way home to Japan from the conference in Banff. In recognition of his distinguished international service and his efforts to promote closer understanding between Japan and
20 Program for Ceremonies Marking the Formal Acceptance by the University of British Columbia of the Japanese Lantern and Garden, August 29, 1935.

21 Vancouver Daily Province, August 14, 1933; Tairiku Nippo, August 18, 1933; Vancouver Daily Province, August 18, 1933.

22 Vancouver Daily Province, August 17, 1933. 
23 The original Nitobe Garden was destroyed in the 1940s. The current Nitobe Garden at UBC is in a different location from the one Mr. Kagetsu sponsored.

24 Vancouver Daily Province, August 30, 1935.

25 Potter, 1967, pp. 36-38.

26 Vancouver Daily Province, October 1, 1934.

27 Tairiku Nippo, October 1, 1934.

28 Potter, pp. 36-40
Canada, the Nitobe Memorial Garden with a Japanese stone lantern was erected on the west side of UBC's campus. ${ }^{23}$ There was a teahouse surrounded by a rock garden. The landscape garden was built around a "lake" and "mountain" with its waterfall and "simulates nature in miniature." The "Ceremonies Marking the Formal Acceptance by The University of British Columbia of the Japanese Lantern and Garden Presented by Friends of Inazo Nitobe" was held on August 29, 1935. My father and members of the family were invited to attend the dedication ceremony. They were seated in the front row in recognition of his significant contribution to this memorial.

The Consul of Japan, Ko Ishii, in presenting the Japanese Lantern and Garden to UBC traced Dr. Nitobe's life and remarked "The lantern, we feel, is symbolic of the shining light of Dr. Nitobe's personality." L. E. Klinck, President of UBC, paid tribute to Dr. Nitobe by characterizing him as, "one of the greatest scholars, Christian idealists, and internationalists of our time."24

\section{Rear Admiral Yamamoto Visit}

Following the Russo-Japanese War, Isoroku Yamamoto rose in rank to Captaincy when he was posted to Washington for two years as a military attache. At the Washington naval conference in 1921, a fleet ratio of three-to-five for capital war ships was adopted. As the militarists gained increasing control over the Japanese government, the outcry against the naval "hold-down" became so great that it was decided in 1934 to hold another conference in London. Rear Admiral Yamamoto was named chief delegate with full powers. ${ }^{25}$

Rear Admiral Yamamoto arrived in Vancouver on October 1, 1934 en route to attend the arms reduction talks in London. While in Vancouver, he toured the city, attended a luncheon hosted by the Japanese Consul, Ko Ishii, and later toured Steveston. My father, as President of the CJA, had a chance to talk with him at the luncheon, as evidenced by his signature in my father's autograph book, and participated in a tour of the city.

The Rear Admiral stated in an interview that Japan believed that disarmament was possible to a considerable scale, that it was her duty to co-operate to that end, and that all nations should abolish armaments in excess of those necessary to national safety. ${ }^{26}$ The naval delegation left later in the afternoon for Seattle, New York, and London. ${ }^{27}$ At the talks in London, Yamamoto on behalf of the Japanese Government, rejected any extension of the fleet ratio that would limit the size of her navy. ${ }^{28}$ 


\section{Prince Chichibu Visit}

Emperor Hirohito chose his younger brother, Prince Yasuhito Chichibu, to represent him at the coronation of Britain's King George VI. At the coronation, the Prince presented King George, in the name of the Emperor of Japan, the "Order of the Chrysanthemum," which only two people in Japan including the Emperor possessed at that time. He also brought gifts for their Majesties. ${ }^{29}$

The Directors of the CJA postponed the election of officers to prepare for Prince Chichibu's visit. My father was elected President after Prince Chichibu left for London and thus missed some of the limelight. ${ }^{30}$

As the Heian Maru approached Vancouver on March 29, 1937, 200 Japanese fishing vessels, brilliant in bunting and flags, formed a runway one and a half miles long crammed with 2,00o waving and cheering Japanese fisherman, their families and friends. Thousands of Japanese including hundreds of Japanese school children welcomed the Prince and Princess at the pier. The official welcoming party consisted of representatives of the Dominion, the Province and the city of Vancouver, as well as the Japanese community and Japanese veterans. ${ }^{31}$ The next morning, Prince Chichibu who expressed a deep interest in the welfare of Japanese expatriates, received a delegation consisting of Consul Nemichi and representatives of eight organizations. Reporters and photographers dispatched from Japanese, American, and Canadian papers gathered outside the meeting hall in Hotel Vancouver.

Their Imperial Highnesses sat on one side of a long table and the representatives on the other side. Consul Nemichi introduced each speaker and his affiliation. My father who sat opposite Prince Chichibu, described the forestry industry and the activities of the Japanese in that industry. The Prince asked about logging and reforestation activities. My father replied that he and others do a certain amount of reforestation. ${ }^{32}$ After the informal luncheon, hosted by the Japanese Consul, the Prince's motorcade of approximately 17 cars, escorted by motorcycle police, proceeded along streets decorated with Japanese flags, the Union Jack, pennants, and bunting. For eight blocks on the approach to the Japanese Language School, the streets were lined with children in kimonos waving both the Union Jack and the Japanese flag and an excited Japanese crowd of six to ten deep.
29 Vancouver Daily Province, March 29, 1937 and March 30, 1937.

30 Canadian Japanese Association, Annual Report, 1937.

31 Vancouver Daily Province, March 30, 1937; Tairiku Nippo, March 30, 1937.

32 Sato, 1969, pp. 288-291; Tairiku Nippo, March 29, 1937. 


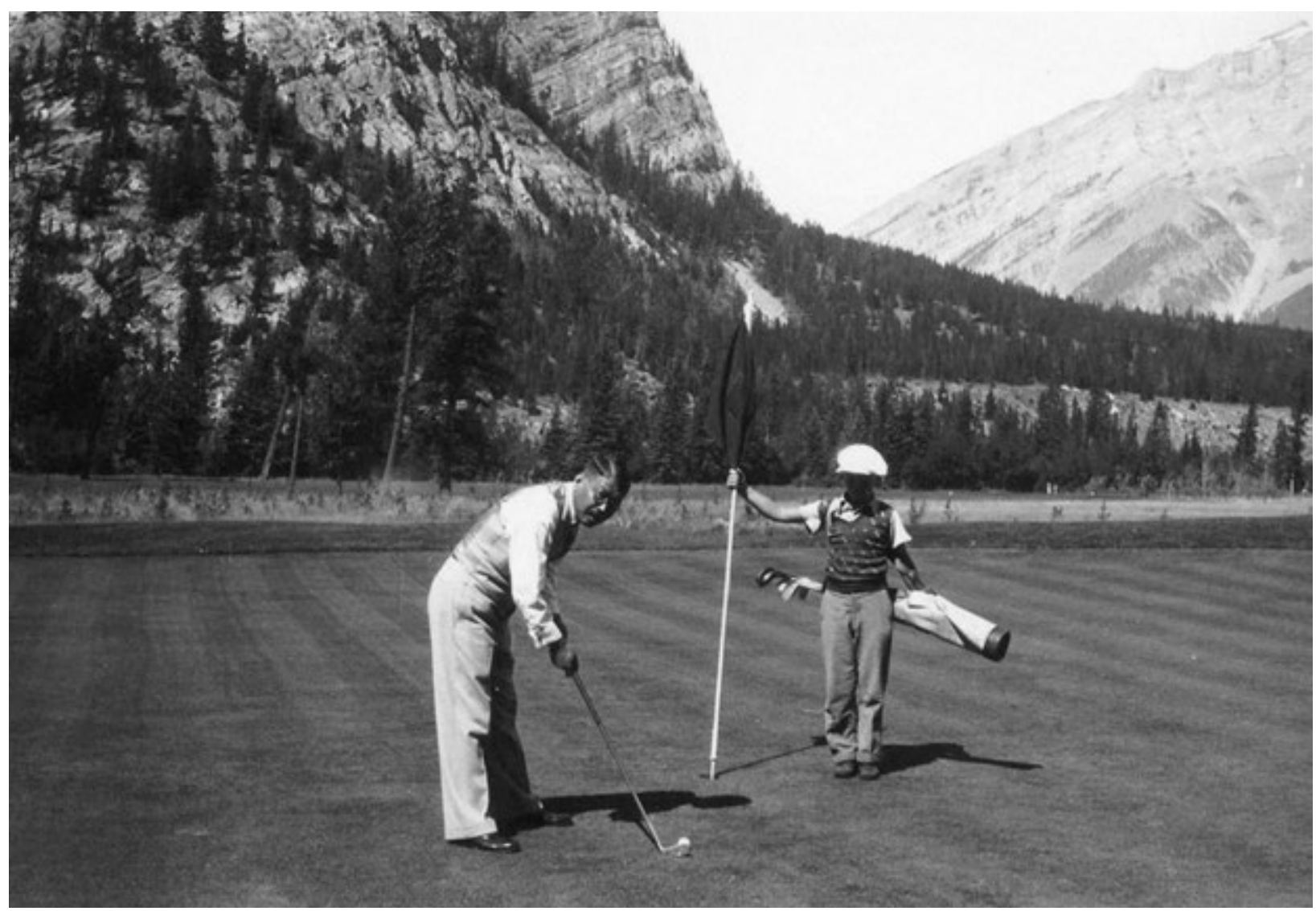

Eikichi playing golf at Institute of Pacific Relations Conference at Banff.

33 Tairiku Nippo, March 30, 1937;

Vancouver Daily Province, March 30, 1937; March 31, 1937.
At the Japanese Language School, the children broke into Kimigayo, the Japanese national anthem, singing its solemn notes as the royal party stood at attention. The Prince was briefed on the state of education (Japanese and Canadian) in BC and inspected compositions of the students. As the Prince departed, he was given three banzai cheers led by Principal Sato. ${ }^{33}$ After the tour of Vancouver, Prince Chichibu attended a formal tea at the residence of the Japanese Consul. At the Hotel Vancouver, the Prince and Princess announced the grant of 2,00o yen to the Saisei Kai to be administered by Consul Nemichi. The CJA, through Grand Master of Ceremonies Matsudaira, pre- 
sented to their Highnesses and their entourage, 20 sets of albums containing photos taken during their commemorative visit of Vancouver. ${ }^{34}$

A reporter wrote: ${ }^{35}$

After one of the most impressive demonstrations of royal acclaim in the history of Vancouver, His Royal Highness Prince Chichibu and his consort boarded their special car at the CNR station on Tuesday night and departed amid the cheers of 10,000 Japanese.

On returning from the coronation of King George VI, Prince and Princess Chichibu stopped in Vancouver on October 1. My father, now President of the CJA, was given permission to accompany the Prince and Princess on their visit to Victoria. ${ }^{36}$

\section{Coronation Day Celebration}

My father and many board members of the CJA accepted His Worship, the Mayor of Vancouver, and the Board of Aldermen's invitation “to be present at the Coronation Celebration to be held at Brockton Point on Wednesday afternoon, May the twelfth, 1937 at one-thirty o'clock." ${ }^{37}$

Several hundred people including the members of the CJA, sat in the grandstand for the "Coronation Day Service." The service reached its climax in a mass dedication administered by the moderator of the Presbyterian Synod:

We in turn, his subjects of the Dominion of Canada, do hereby dedicate and consecrate ourselves to the service of God in loyal obedience to our King and the promotion of the true welfare of our country.

The Service concluded with "O Canada" and the benediction. ${ }^{38}$

\section{King George VI Visit}

A month before the visit by their Majesties, King George and Queen Elizabeth, sixty representatives from forty-five Japanese organizations met at the Japanese
34 Tairiku Nippo, March 31, 1937; Vancouver Daily Province, March 31, 1937.

35 Vancouver Daily Province, March 31, 1937.

36 Canadian Japanese Association, Annual Report, 1937.

37 Canadian Japanese Association, Annual Report, 1937.

38 Vancouver Daily Province, May 12, 1937; Coronation Day Service - Order of Service. 
Japanese Canadian welcoming committee for King George VI included left to right: $R$. Ide, E. Kagetsu Chairman, G. Nakayama, Dr. G. Ishikawa and K. Morino.

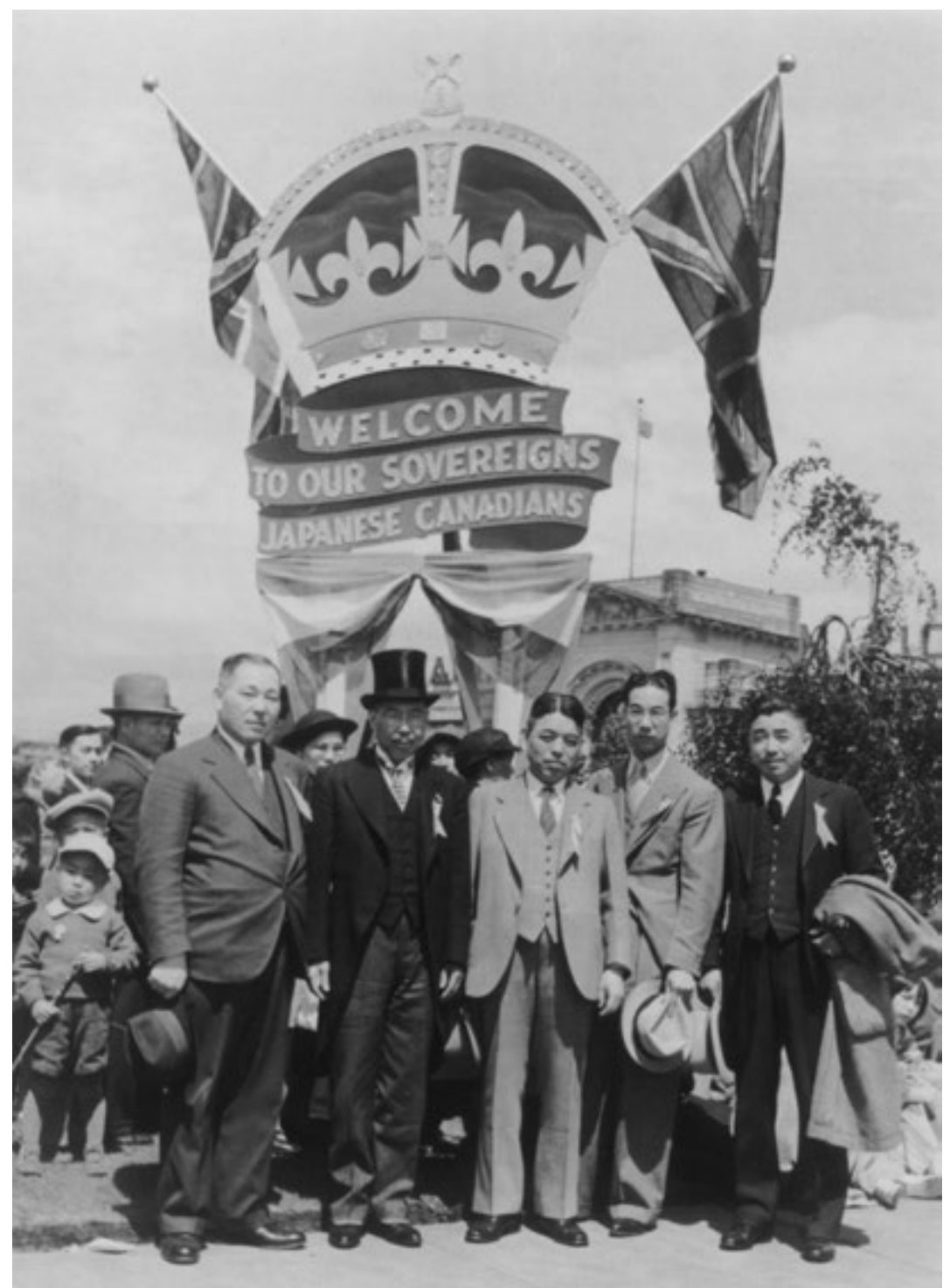


Hall under the auspices of the CJA to formulate plans to welcome the Royal couple. My father was the chairman of the Japanese Royal Welcome Committee. A sub-committee of twenty-five persons representing various groups was appointed. ${ }^{39}$ Plans were finalized to place a large banner bearing the words "Japanese Community" at the intersection of Main and Powell Streets, and to construct a six feet by six feet crown that would stand above the crowd at the corner of Terminal Avenue and Main Street to symbolize the welcome by Japanese Canadians. ${ }^{40}$

The sentiments of the Japanese Canadians concerning this visit were expressed eloquently by their newspapers. The New Canadian published a Special Edition commemorating this event. In it, the editor stated in part, ${ }^{41}$

And it is perhaps peculiarly significant that we, both first and second generation Japanese in Canada, are blessed with a cultural heritage which teaches us to revere and to love the head of the state, who is essentially the father to all his people. Perhaps more than any other group in this Dominion, do our people share this feeling of love and affection for the titular head of the state.

This special issue of the New Canadian with the co-operation of both first and second generation throughout the entire province has attempted to give that love some token of expression-for we may well feel the deepest and sincerest love of country, love for the land to which we owe so much, love for the land of our birth, love for the land that is our home.

The Tairiku Nippo provided wide coverage on the Royal couple and their family. Five articles in Japanese appeared in the May 29 issue. An editorial entitled "Our King" said the following: ${ }^{42}$

Whatever may be said by questioners of our loyalty to Canada and the British Empire and the principles of democracy, none can deny us, the Canadians of Japanese ancestry, that unexplainable excitement at the mere thought of the approaching visit of Their Majesties.

Loyalty cannot be measured simply by the amount of bunting we can display but within the privacy of our thoughts surges a real and sincere affection for the royal pair who are the heads of the greatest empire in the world and Canada our birthplace.
39 Tairiku Nippo, April 29, 1939

40 Tairiku Nippo, May 20, 1939; The New Canadian, May 27, 1939.

41 The New Canadian, May 22, 1939, Special Edition.

42 Tairiku Nippo, May 20, 1939, English Section. 
On May 29, Mayor Telford welcomed the King and Queen. They then travelled by open motorcade to City Hall. Sidewalks along the way were packed solid with expectant throngs that cheered "Long Live the King." At City Hall, the Mayor presented civic dignitaries and war heroes to the King and Queen. An ensemble of 1500 singers and seventy-five instruments rendered "God Save the King" such as Canada has seldom heard before. ${ }^{43}$ By 12:30pm hundreds of Nisei girls, dressed in picturesque Japanese kimonos and waving the Union Jack and welcome pennants, formed a double line stretching all the way on the north side-from the corner of Terminal Avenue and Main Street to the end of Thorton Park. When the Royal couple appeared, spontaneous cheering broke forth from the girls and hundreds of other Japanese Canadians grouped behind them. The gracious Queen was noticed giving a wifely tug to His Majesty as the carriage drove and as the entourage drove by, she turned backward, giving all just one more glimpse of the smile that endeared her to all of Canada. This striking spectacle was unique in the entire series of welcomes that greeted the Royal couple on their visit to Canada. ${ }^{44}$

On May 31, as the Royal couple returned to Vancouver from Victoria, a large flotilla of over 200 Japanese fishing boats moved out to the Gulf of Georgia to greet them with fluttering Union Jacks and tricolor streamers hoisted on their masts. They strung out to form a single file and raced alongside the Prince Robert as it steamed across the mouth of the Fraser River. On their return to Vancouver, as the Royal couple left the Canadian National dock and proceeded north on Main Street and at Powell Street, they saw the banner "Japanese Community." The business section of Powell Street was gaily decorated with flags and bunting in honour of the festive occasion. ${ }^{45}$

\section{Governor General Lord Tweedsmuir's Death}

Lord Tweedsmuir, the Governor General and the King's representative in Canada, died on February 11, 1940. John Buchan and Harry Naganobu, National President of the Japanese Canadian Citizens' League, wired condolences of the Nisei to the Prime Minister. In his message to the Prime Minister, my father, expressed the sympathies of the CJA to Lady Tweedsmuir on Lord Tweedsmuir's passing: ${ }^{46}$

The members of the Canadian Japanese Association join with me in sending a heartfelt message of sympathy at the passing of Lord
43 Vancouver Daily Province, May 29, 1939.

44 The New Canadian, June 6, 1939.

45 The New Canadian, May 27, 1939. 
Tweedsmuir. It is a great loss to our country. Please convey our deepest sympathy to Lady Tweedsmuir.

In earlier years, as President of the CJA, my father would have spoken for all of the Japanese Canadians. With the formation of the JCCL who represented the Nisei, my father was careful in speaking for the Isseis only. 


\section{CHAPTER 14}

\section{The Vimy Pilgrimage
and Berlin Olympics}

\section{The Vimy Pilgrimage}

\section{Shinobu, 1936, p. 1.}

2 Tairiku Nippo, April 9, 1920; Vancouver Daily Province, April 9, 1920; Shinobu, 1936; The New Canadian, May 27, 1939. See also The New Canadian, September 8, 1939; Ito, 1994, pp. 82-85. $\mathrm{n}$ the spring of 1917, during the First World War, the strategic hilltop of Vimy

Ridge on The Western Front in France had already been held by the

Germans for three years. The French army had attempted in vain to regain that stronghold at a cost of 15,00o dead and wounded. It was on April 9, 1917 that four divisions of Canadian soldiers, after suffering casualties of over 11,000, captured the Ridge and brought the name of Vimy Ridge to the eyes of the world. ${ }^{1}$ There stands on the beautiful grounds of Stanley Park a monument erected in 1920 to the memory of 54 Japanese-Canadian soldiers who gave their lives for Canada during World War I. It also stands as a silent tribute to all Japanese-Canadian veterans who fought for Canada. ${ }^{2}$

To honour the memory of the Canadian soldiers who made the supreme sacrifice in the cause of freedom and justice, the Canadian government built a beautiful monument at Vimy Ridge on an expanse of land ceded to Canada by France. The unveiling of the Memorial by King Edward VIII was held on July 26, 1936. The Canadian Legion Dominion Branch sponsored and organized a pilgrimage for veterans, their families and relatives, and others to attend the ceremony in France. By the March 14, 1936 deadline 6,400 applications had been submitted. 
The Japanese Division of the Canadian Legion took this opportunity to pay tribute to the 54 Japanese Canadians buried in the battlefields of Northern France. Mr. Bunjiro Furukawa, who served in the 5oth Battalion in France, and Mr. Saburo Shinobu were selected as their representatives. On a recommendation by the Japanese Division, the Canadian government invited my father, who was President of the CJA, as a delegate to represent the Japanese Canadians in Canada. ${ }^{3}$ On July 8, 1936, Messrs. Furukawa and Shinobu, along with my father, his wife, and their children, Kimiyo, Hajime, and Takako, left Vancouver on a Canadian Pacific Railway train. The station platform was crowded with well-wishers. A number of organizations presented my father with a basket of flowers.

En route to Montreal, the group stopped in Toronto, Niagara Falls, and Ottawa where they visited the Japanese Embassy. The Embassy staff took them to see the Royal Mint and Parliament buildings and invited them to lunch. They arrived in Montreal on the evening of July 15 and went sightseeing the next day. People were converging on Montreal from all over North America. The 6,400 pilgrims were divided among five steamships that departed on July 17. The Japanese group boarded S.S. Montcalm for a 11am departure. ${ }^{4}$

As the ship sailed down the St. Lawrence River, each pilgrim was provided a haversack, guidebook, badge, beret, and pin inscribed with the name of the ship and their group number. The last three items had to be worn at all times for the purpose of identification. The colour of the veterans' berets was khaki and all others were navy blue. ${ }^{5} \mathrm{Mr}$. Shinobu recalled: ${ }^{6}$

Perhaps it was because we were Japanese that we were particularly welcomed into all the activities. Feeling that this was a means of fostering better Japanese-Canadian goodwill, we gladly joined in the games, even though we were clumsy and awkward. Mr. Kagetsu's children being naturally friendly and being fluent in English, were very popular and sought after when any new activity was started. I believe one reason we made such a good impression on the rest of the pilgrims was due largely to the influence of Mr. Kagetsu's family.

Early on Thursday morning, July 23, there was much excitement as England was sighted in the far distance. The ship passed the white cliffs of Dover and dropped anchor in the evening outside the Port of Flushing in Holland. The boat proceeded to Antwerp, Belgium during the night and docked there on

3 Shinobu, p. 1.

4 Montreal Gazette, July 16, 1936.

5 Hundevad, 1936b, p. 20.

6 Shinobu, pp. 8-10. 
Saturday morning. After breakfast, the pilgrims disembarked and boarded four trains as a Belgian army band welcomed them.

The train headed northward and crossed into France two hours later. It stopped at Lille where lunch for 2,500 people was served at the exhibition hall. The train's last stop was Douai. Buses transported the Canadians to a battle area near the River Somme and to cemeteries where Canadian soldiers were buried. Wherever they went, the towns were bedecked in flags and the local townspeople waved their handkerchiefs to welcome them with joy. The pilgrims arrived in Armentieres at 10:30pm, had dinner, and were billeted in various designated quarters. ${ }^{7}$

\section{The Unveiling by H.R.M. King Edward VIII}

The next morning, Sunday, July 26, they were transported to Vimy. The road leading to Vimy was filled with a continuous stream of people going to the unveiling on foot, on bicycles, and in automobiles. Approximately half a mile from the war memorial, they were allowed to explore the trenches, tunnels, sniper stations, sentry posts, subterranean rooms, etc., that had been built by the Germans.

They then proceeded to the magnificent Vimy War Memorial. ${ }^{8}$

The Canadian Army War Memorial built on the top of Vimy Ridge is 230 feet long and has a 185 -foot wide platform from which soar two pylons. One, symbolizing Canada, has on the top of the inner wall, sculptured figures representing Peace and Honour. The other pylon, representing France, is embellished on the inner wall with figures representing Justice and Faith.... The central figure of a cowled, sorrowing woman standing on the platform represents Canada mourning her dead. On the memorial is inscribed these words, "To the valour of their countrymen in the Great War and in memory of their sixty thousand dead, this monument is raised by the people of Canada". Then on the gigantic base of this memorial are inscribed the names and regiments of some 11,000 Canadian soldiers with no known graves, and included in these

9 Murray, 1936, p. 65; Montreal Gazette, July 27, 1936.

Close to 100,000 persons including the French military and French citizens were present at the unveiling site. ${ }^{9}$ H.R.M. King Edward VIII arrived at 2:15pm 


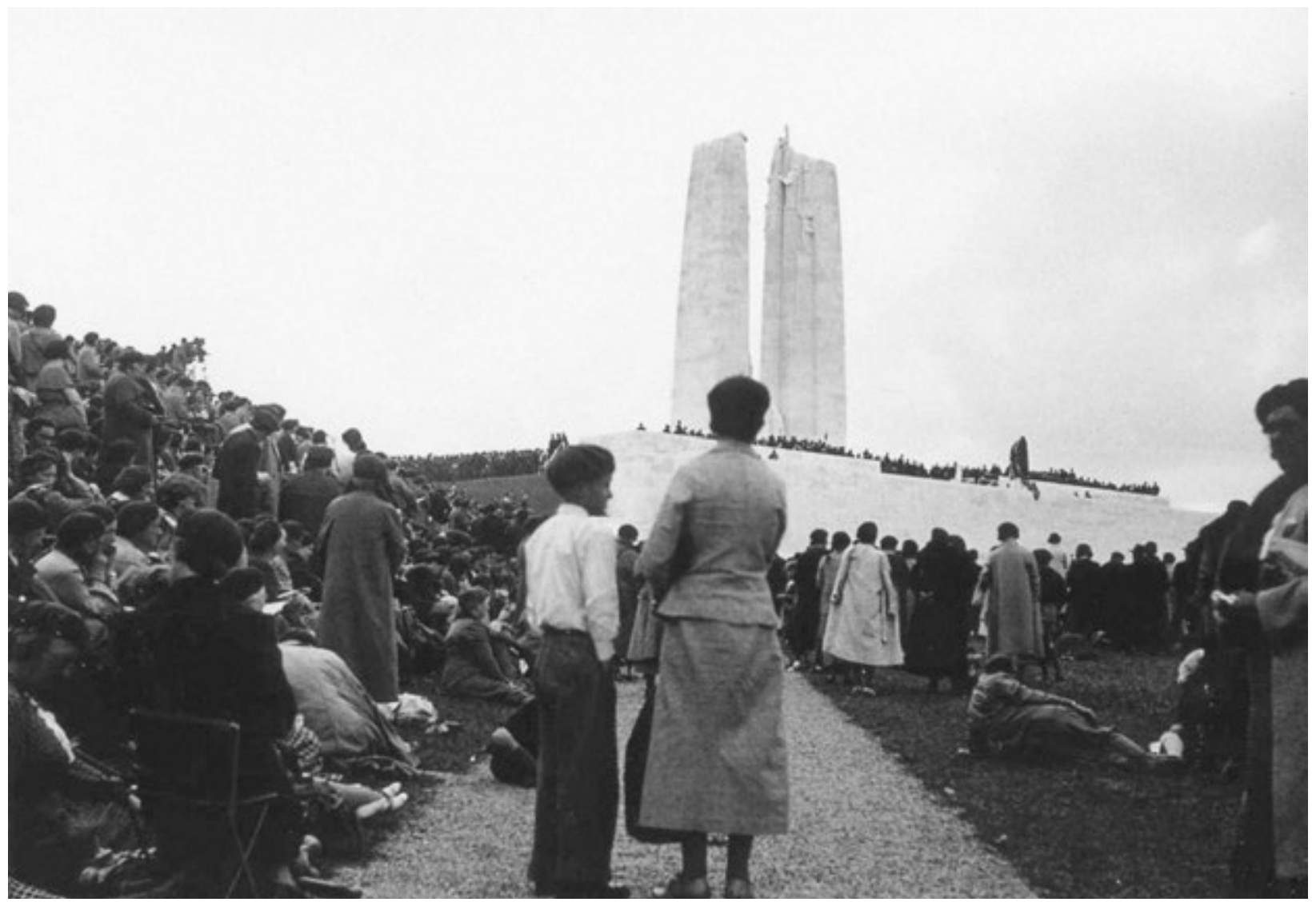

Crowd at Vimy Memorial Unveiling.

and the band played "God Save the King" and "O Canada." The King inspected the Guard of Honour and the veteran's Guard of Honour. The King then greeted President Lebrun of France. Squadrons of the Royal Airforce and of the French Airforce flew over and dipped their wings in salute as they passed. The memorial service conducted by military and religious representatives followed. The unveiling ceremony continued with speeches by Canadian government officials including a message from the Right Hon. W. L. Mackenzie King, Prime Minister of Canada.

Beginning his remarks in French, King Edward thanked President Lebrun for his presence and the French nation for the honour bestowed upon the 


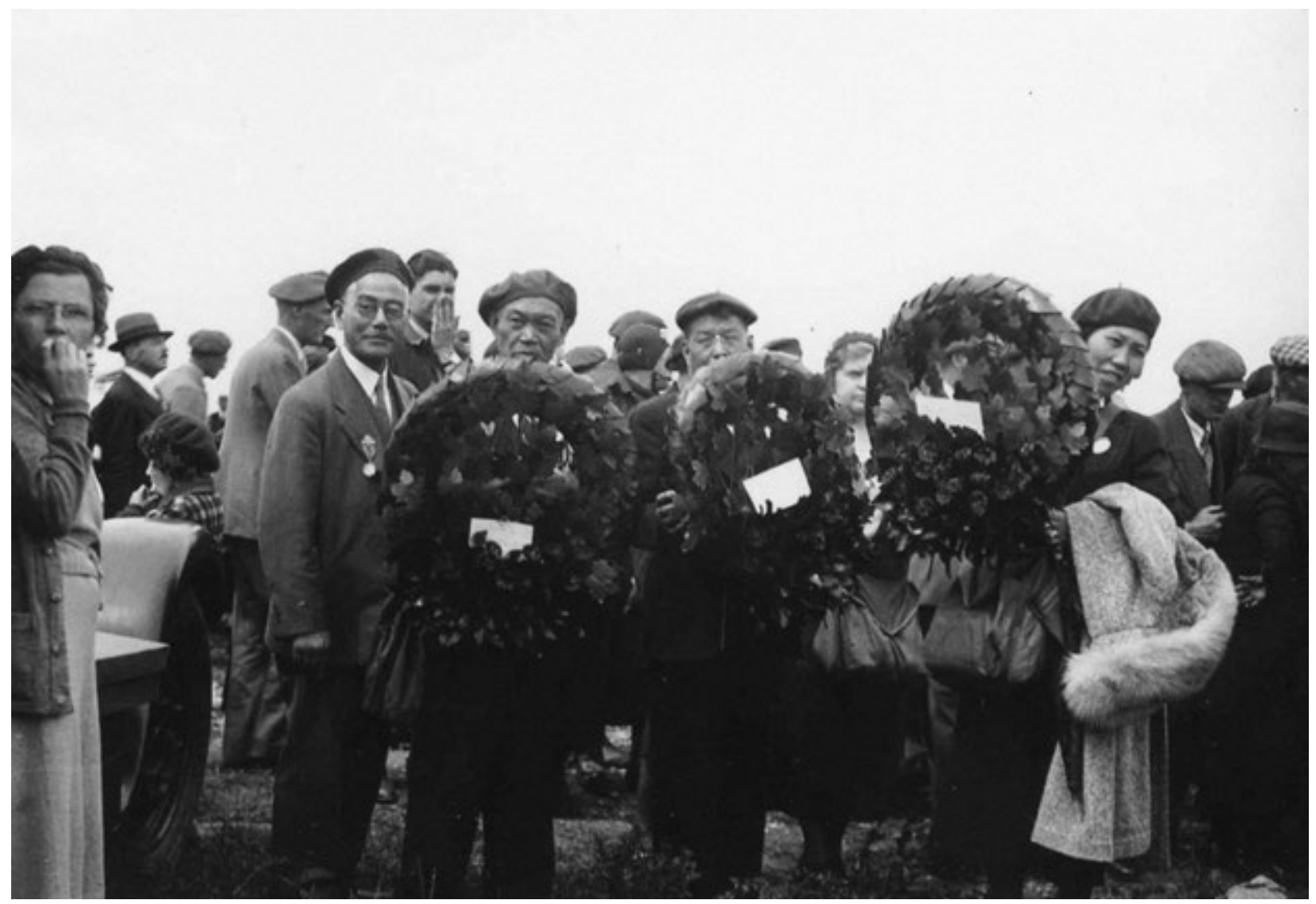

Wreaths laid at the base of the Vimy Memorial monument by left to right: Saburo Shinobu, Bunjiro Furukawa, Eikichi Kagetsu, and wife Toyo.

Canadian soldiers whose sacrifice was inscribed on the Vimy Monument and for the welcome accorded to the pilgrims. His Majesty continued eloquently in English. He touched everyone's heart when he stated:

For this glorious monument crowning the hill of Vimy is now and for all time part of Canada. Though the mortal remains of Canada's sons lie far from home, yet here where we now stand in ancient Artois their immortal memory is hallowed upon soil that is surely Canada's as any acre within her nine provinces. 
At the end of his address, the King said:

In that spirit, in a spirit of thankfulness for their example, of reverence for their devotion and of pride in their comradeship, I unveil this memorial to Canada's dead.

He then released the Union Jack and unveiled the figure of "Canada Mourning Her Dead." The crowd fell silent as "The Last Post" and "Reveille" were sounded. Following the playing of the national anthems of the two countries, His Majesty and the President each laid a wreath on the Memorial. ${ }^{10}$

After the ceremony the Japanese-Canadian representatives, Mr. Furukawa, for the Japanese Branch of the Canadian Legion, my father, for the CJA and my mother, [Toyo Kagetsu], for the Buddhist Church, placed their wreaths at the base of the Memorial. Then they negotiated their way through the crowd to look for the names of 24 Japanese-Canadians soldiers killed in action chiseled on the walls of the memorial. My father may have found his cousin's name, Tsunematsu Yamazaki of the 5oth Battalion.

\section{The Search for the Japanese-Canadian War Dead}

That evening they attended a concert given by the city of Armentieres. My father decided to separate from the main group the next day in order to find the graves of the Japanese-Canadian war dead and to pay his respects. At $7 \mathrm{am}$ the next morning, Mr. Furukawa, my parents, and Mr. Shinobu set out by taxi using records obtained from the Canadian Legion headquarters in Canada. They had difficulty communicating with the French driver who did not know the area and had to stop often to ask for directions. They finally found the Bruay Cemetery and the graves of two Japanese Canadians. They laid flowers brought by my mother and took pictures. Then they headed for the cemeteries in the Arras district. ${ }^{11}$

About 11am, the taxi broke a gear and the driver called his head office 70 miles away in Armentieres to send another taxi. There was going to be an hour and a half delay! There they realized that they were in Aix Noulette and were able to find the graves of three more Japanese-Canadian soldiers. Again, flowers were laid and pictures were taken. This process was repeated at each cemetery.

Not having had breakfast, they found a small restaurant nearby where one of the helpers was an English woman. After ordering their lunch, they told her
10 Murray, pp. 88-98; Montreal Gazette, July 27,1936

11 Shinobu, pp. 28-35; Ito, 1984, pp. 288293. 
their troubles. My father needed additional French money to pay the cab driver and asked her if she could change two pounds English currency for him. The lady went out and returned with an English gentleman named Mr. Sterling, who exchanged the currency. Then to their great amazement and delight, they learned that he was the supervisor of the caretakers for all the cemeteries in this area. They showed him the list of Japanese-Canadian graves. Mr. Sterling said:

For a stranger to look for unfamiliar graves, it is a rather complicated business. I, myself, shall take you on a tour of the graves in time for you to catch your train at Lille.

Mr. Sterling drove the group in his car and took shortcuts unknown to most people. They visited four cemeteries and found the graves of five more Japanese Canadians. ${ }^{12}$ It was around 3:30pm when they warmly thanked Mr. Sterling and raced 60 miles by taxi to the Lille Railway Station where they rejoined the main group who had spent their day visiting different battlegrounds and cemeteries. The Kagetsu family were together again for the train ride to Antwerp. The group boarded S.S. Montcalm heading for England.

\section{Events in London}

The next morning, the ship docked at Tilbury and the group took trains to London. They received a great welcome by the citizens and members of the British Legion. They boarded double-decker buses which they saw for the first time and got off at their designated hotel. On the morning of Wednesday, July 29 at 10am, the pilgrims from Canada attended Westminster Hall where Prime Minister Baldwin of Great Britain spoke to the gathering with his usual "beauty of expression." He spoke of the aid given to Great Britain during the war and how great deeds had been performed in many places, and how he hoped the bond between Britain and the Dominion would ever become stronger in the future. He finished his address by expressing concern over the present unrest in Europe.

The Canadian pilgrims then paraded past enormous crowds to the Cenotaph to pay homage to the Empire's war dead. The Bishop of London conducted the service at 11:30am. The Canadian Legion placed a wreath at the 
and "God Save the King." The Bishop concluded the service with a short message and the benediction.

In the late afternoon, the Japanese-Canadian delegation with other Canadian pilgrims attended a garden party at Buckingham Palace at the invitation of His Majesty King Edward. This event was the crowning feature of the pilgrimage and was described as "unprecedented" by the newspapers. Most pilgrims were dressed informally and helped themselves to tea and cakes at the refreshment tents. His Majesty appeared on the grounds just as the "rain began to fall in torrents." He honoured the group with personal words of welcome and chatted with a number of veterans. Later, the King appeared on the balcony and delivered an impromptu speech that "dwelt on Canadian memories and happily expressed a friendly welcome." ${ }^{13}$

Over the next two days the Japanese-Canadian group went sightseeing by bus. They went to the British Museum with a Japanese guide provided by the Japanese Embassy. They spent a day at Stratford-upon-Avon to see Shakespeare's birthplace. On Friday afternoon, His Excellency Shigeru Yoshida, the Japanese Ambassador to Great Britain - who later became Prime Minister of Japan-invited my father and family to afternoon tea at his residence. ${ }^{14}$ My parents and Takako accepted the gracious invitation while Kimiyo looked after Hajime who was not feeling well. Ambassador Yoshida invited a few staff members and their wives. Ambassador Yoshida and my father sat together and talked the whole time. My father had a knack for making friends. The wives chatted and had tea. Ambassador Yoshida's charming daughter entertained Takako.

\section{Invitation to France}

The French Government invited the Canadian pilgrims to visit Paris for five days and paid all their expenses. They departed London by train in the evening. At Dover, they boarded steamers to Calais. From there they traveled by train. They had a terrible time trying to sleep on wooden seats. They arrived in Paris early in the morning where they were met by over 100 buses that took them to their respective hotels.

During the afternoon bus tour they saw many interesting sights and on the evening tour they saw a beautiful city lit by floodlights. The tour the next morning was followed by a welcoming banquet, presided over by Marshall Petain at the Palais des Invalides, was given by the French Confederation of War Veterans. Later that afternoon, they were taken to the Palace of Versailles

13 Murray, pp. 118-134.

14 Dower, 1979, pp. 110, 117-118. 
where they saw the Hall of Mirrors made famous by the signing of the Treaty of Versailles and the magnificent murals, paintings, and period furniture. Rain prevented them from getting a good look at the gardens with their beautiful fountains and statues. Wherever they went, the local people lined the way cheering and waving their handkerchiefs.

On the morning of Monday, August 3, they went by train to the old town of Amboise on the Loire River where they toured the famed castle. Later that afternoon, they boarded trains to Boise where they paraded and toured the ancient Chateau de Boise, part of which dated back to the 13th century. The Director-General of the League of Nations was among those who spoke to the pilgrims at an outdoor welcoming reception and banquet. It was near midnight by the time they returned to Paris and their hotels. ${ }^{15}$

The next day they visited Rouen where the crowds of people shouted "Vive la Canada!" as they waved small flags wildly. The banquet for 6,00o people was held in one huge room. The speeches by government officials were all in French. Later, after paying homage at the monument of Joan of Arc, they returned to Paris.

On Wednesday, August 5, the Japanese-Canadian group visited His Excellency Naotake Sato, the Japanese Ambassador to France, at his beautiful Japanese-style home. They toured Le Louvre guided by a Japanese art student provided by the Japanese Embassy. The student gave them an in-depth commentary on the paintings and sculptures. The Mona Lisa with her enigmatic smile was recognized by all. After supper at a Japanese restaurant, they attended the world famous Folies Bergere. When the five-day trip ended, the JapaneseCanadian group said goodbye to the Vimy pilgrims who returned to London via Dieppe. The Official Vimy Pilgrimage ended with a reception and the Canadian pilgrims were free to travel their separate ways.

\section{Off to Berlin for the XI Olympic Games}

The Japanese-Canadian group decided to attend the Summer Olympics and left for Berlin on Thursday, August 6. In Berlin hotel rooms were scarce for the Olympics. The Japanese Embassy found a private home that had rooms for our family members and they were driven there by an Embassy car.

The XI Olympic Games was held August 1 through August 16, 1936. The Nazi Party had risen to power in Germany. Its leader, Adolph Hitler, used this 
signs were removed. Hitler's plan was ruined by one black American athlete, Jesse Owens, who won four gold medals in the men's track events. The Japanese Embassy purchased tickets to the Olympic events for the group. They saw Hitler as he entered the main stadium. There were swastikas displayed everywhere and the Germans greeted him with "Heil Hitler!" There were track and field events to see, as well as synchronized exhibitions by hundreds of athletes on the field.

Japan sent a strong swimming team, and therefore, the Kagetsus spent some time at the swimming venue. The Japanese men's swimming team won three gold medals and a total of eight medals while breaking four Olympic records. Of great interest to my parents was a young girl, Hideko Maehata, from their home prefecture, Wakayama. In the qualifying heat for the 200 metre breast stroke, she broke the Olympic record with a time of 3:01.9. In the exciting finals, Maehata was neck to neck with Germany's Martha Genenger. It was a "photo" finish and Maehata won by less than one second. ${ }^{16}$ My mother, who was a good swimmer herself, was ecstatic. It must have been an emotional moment when the hinomaru - the Japanese flag-was raised and kimigayo-the Japanese National anthem - was played at the presentation ceremony.

They stayed in Berlin until August 10, attending the Olympic Games and sightseeing. Goose-stepping German soldiers were parading everywhere. Watching the planes at the airport was interesting as commercial air travel was in its early days. The Berlin Zoo was large and had many interesting animals, such as the rhinoceros, elephants, and camels, which they had never seen live before. The next day, a train took them to Weisbaden where they boarded a boat that took them down the Rhine River. It was a relaxing trip. The vineyards on the steep banks were neatly cultivated. They passed the famed Lorelei, a rock feature, where sailors were supposedly lured to their deaths. They disembarked at Koblenz, and reached London, England the next morning.

They spent a week sightseeing. Some of the highlights in London were the Tower of London, the British Museum with very interesting manuscripts of music, the Science Museum which displayed engines of every description, and the National Galleries. They spent an afternoon at Oxford and walked around Oxford University, Christ Church Cathedral, and other attractions. On Sunday, August 16, Kimiyo, Hajime and Takako took a nine-hour train ride for a threeday trip to Scotland. They toured Edinburgh and Glasgow. They traveled all night and arrived at London's Kings Cross Station the next morning. The next day, they went to Windsor where they saw St. George's Chapel and followed their guide to the state apartments in Windsor Castle-the rooms were much nicer than those at Versailles. On Friday, August 21, they began their journey 
home by travelling to Liverpool and boarded the S.S. Samaria at 9pm. Exactly eight days later, the ship arrived in Boston. They remained on board and disembarked at New York City two days later. They went sightseeing the same day and boarded a train to Montreal at 1opm. The next day they went sightseeing in Montreal and boarded a CPR train for Vancouver at 7:15pm. A little over three and a half days later, they arrived back at the CPR station in Vancouver, where they were greeted by a large number of friends.

On their return, my father commented:

On this trip, we went sightseeing in many of the major cities of Europe. With their older culture and civilization, there were many historic landmarks to see. However, as far as living standards go, they can't surpass Canada. 
TREE TRUNK - MY PILLOW I KAGETSU 
CHAPTER 15

\section{A Great Honour is Savoured}

\section{A Special Kigensetsu}

1 Encyclopaedia Britannica, Japan, Vol. 12, p. 901; Kodansha, 1983, Vol. 1, p. 51.

2 De Garis, 1950, p. 437; Britannica, p. 902; Kodansha, Vol. 2, p. 203; Vol. 4, p. 57.

3 DeGaris, p. 3; Kodansha, Vol. 6, p. 175.

4 Tairku Nippo, February 12, 1940.

\begin{abstract}
A ccording to legend, Amaterasu Omikami the sun goddess helped produce the land and people of Japan. ${ }^{1}$ Many generations later, Prince Kamu Yamato Iware-Hiko led an army against rebels in Yamato province. He defeated the rebels and organized a government. He was enthroned as the first Emperor of Japan in 660 B.C.. Scholars set the date as February 11, which is still celebrated today as Kigensetsu and gave the Emperor the title Jimmu Tenno. ${ }^{2}$ During the Meiji period $(1868$ - 1911), a dating system that started with the enthronement of Jimmu Tenno in 660 B.C., was approved. Although this system provided a continuous chronology, it was used sparsely. ${ }^{3}$

On February 11, 1940, approximately 150 local Japanese celebrated the Imperial Calendar Year of 2600 at the official residence of the Japanese Consul in Vancouver. ${ }^{4}$ The CJA sponsored an elaborate program to celebrate this day at the Japanese Hall. Chairman Kagetsu reverently gave a congratulatory speech followed by Consul Nakauchi's inspiring speech. The celebration ended with the singing of the official 26ooth year anthem. A movie was then shown.

Later in the evening a banquet to celebrate the event was held at the Fuji restaurant with approximately 110 people attending. After toasts were raised, an opening speech was given by Chairman Kagetsu. Consul Nakauchi then
\end{abstract}


gave a thought-provoking speech wherein he outlined his views on the education and training of the Nisei who would eventually become the leaders of the next generation. ${ }^{5}$

As official representative of the Overseas Japanese in Canada, my father received an invitation from the Ministry of Overseas Affairs and the Ministry of Foreign Affairs, in Tokyo, to attend the 26ooth anniversary celebration of the Japanese Empire. ${ }^{6}$ My father had a book prepared to give to the people he met in Japan to inform them about Canada. He selected Jinshiro Nakayama, a wellknown Japanese-Canadian author, as editor and gave him an outline of what he wanted. The files of the CJA contained much of the information that was used.

The book contained geographical and population features of Canada and detailed statistics on the dollar value of the main products it manufactured. The agricultural, fishing, forestry and mining industries were covered by citing production volume and dollar value of the main products together with data on the participation of the Japanese in these industries. The major items of export to and import from Japan were listed and the data showed that Canada exported much more to Japan than it imported. These items took up about two-thirds of the book.

There was a chapter devoted to the education of the Niseis in Canadian and Japanese schools. Activities of the Japanese in Vancouver, Steveston, and Victoria were described. General information on the city of Vancouver, such as area, population, weather etc., was provided along with a brief history of the CJA and a list of Japanese-Canadian organizations. A section on "Japanese Pioneering Immigrants to Canada" described some of the early history. The final section dealt with the "Anti-Japanese Sentiment" - a "continuously troublesome main issue of the Japanese who have been trying to integrate themselves into the mainstream Caucasian society." ${ }^{7}$

The book was titled Kanada to Nihonjin (Canada and the Japanese) - In Commemoration of the 26ooth Anniversary of the Japanese Imperial Calendar. The colophon indicated that Eikichi Kagetsu was the publisher, but there was no mention of an editor or author. This 78-page book contained relatively little on the history of the Japanese in Canada after 1900 probably because it was initiated in early May and published on October 5, 1940-two weeks before my father departed for Japan.

An identical edition was published by the CJA citing Jinshiro Nakayama as the editor. Mr. Tsuneharu Gonnami, librarian at UBC's Asian Library translated the book, citing Mr. Nakayama's editorial role and Eikichi Kagetsu's publication rights as a result of a large cash contribution to the CJA. ${ }^{8}$ The author's
5 Canadian Japanese Association (CJA), Annual Report, 1940; Tairiku Nippo, February 12, 1940.

6 Continental Times, January 1, 1976.

7 E. Kagetsu's Third Diary, translated by Takako Huang.

8 Armor \& Gonnami, 2000, pp. 6-7; Translation of Kanada to Nihonjin, pp. 188-285. 
view was that Eikichi Kagetsu initiated and supervised the writing of this book. The publication of the book, which was a big undertaking, was not mentioned in CJA's 1940 Annual Report. ${ }^{9}$

\section{Eikichi Kagetsu Joins the Celebration in Japan}

The Kyoeikai held a farewell party for my father on October 5 . He departed from Vancouver on October 19 onboard the Hiye Maru for his trip to Japan. He wrote, "I feel very honoured by this invitation from the Government." On arriving in Japan, he spent a short time visiting with his sisters and other relatives in Wakayama Prefecture. When he returned to Tokyo on November 4 he visited the Yasukuni Shrine and the Meiji Shrine. The next day, he attended a meeting of the Kaigai Zai Doho Tokyo Kai (Tokyo Branch of Japanese Living Abroad).

From November 6 through 8, my father attended the Conference of Representatives of Japanese Living Abroad sponsored by the Ministries of Foreign Affairs and Overseas Affairs in Japan. The overseas delegates received a warm welcome by government officials. Two Tokyo newspapers covering the event printed comments made by Eikichi Kagetsu. ${ }^{10}$

The scope of this conference can be seen by the invitees listed below: ${ }^{11}$

9 CJA, Minutes, April 1934; CJA, Annual Report, 1940.

10 Kokumin Shinbun, November 3, 1940, Evening Edition; Tokyo Nichinichi Shinbun, November 6, 1940, Morning Edition.

11 Tokyo Conference of Overseas Japanese in Celebration of Year 2600 of the Imperial Calendar, pp. 5-6. (a) Participants: approximately 1000 compatriots from Hawaii, Canada, USA, Central America, South America, Manchuria, China, Oceania, India, and Australia.

(b) Media representatives: approximately 50 representatives from overseas Japanese presses.

(c) Special invitation: approximately 300 representatives from organizations in Japan connected with overseas development, and those compatriots and businessmen who have rendered distinguished service overseas.

(d) Special guests: approximately 100 from various related Ministries.

(e) Special participation: approximately 600 Nisei overseas compatriots residing in Japan.

The objectives of the Conference included:

(a) Joint celebration of Year 2600 with overseas Japanese. 
(b) Liaison between overseas organizations and home organizations.

(c) Study of problems faced by overseas children.

(d) To inform overseas compatriots of conditions at home.

(e) To inform through overseas compatriots conditions at home (Japan) to their host countries.

(f) To receive information through overseas compatriots of conditions of their host country.

On November 7, my father spoke at the Conference and began his talk as follows: ${ }^{12}$

Earlier, I was asked to speak frankly, and I feel somewhat delighted. In inviting us to this conference, I felt that I was being rewarded for all the past hard work and that this has been recognized.

As for conditions in Canada, I will begin by going through the pages of the booklet that I have prepared for each of you. Although Canada is a very large country, its population is very small. Furthermore, it is underdeveloped. As a result, Canada tends to be forgotten. Whenever there is an event, many people regard letters from Canada as coming by way of North America. There are many people who still do not understand that Canada is Canada, a separate country. I would now like to talk a little about the history of Canada.

He explained how the original French colony became the Dominion of Canada under British rule and how the population was composed of people of different national descents. He described the forestry, agricultural, fishing, and mining industries in Canada and the imbalance between exports to and imports from Japan. The participation of Japanese in the above industries and the problems they faced were discussed. He finished his presentation by describing the Japanese businesses in Vancouver and the education of Niseis in English schools and Japanese language schools. Later, in a follow-up to another speaker, my father made the following statements: ${ }^{13}$

In Canada, discrimination against the Japanese is stronger. Even I was watched closely when coming here. The Kanada Nihonjinkai committee on current affairs is engaged in various projects, and

12 Ministry of Overseas Affairs, 1940, pp. 51-56. Full text can be found in Appendix III.

13 Ministry of Overseas Affairs, pp. 86-87. 
as the president, I am watched closely at all times. The authorities think the president is the ringleader. I was worried at one time if I would ever be allowed back into Canada. I asked the Consul for his advice. That is why I came here with a special "exemption" from the government.

We are well aware of the wartime conditions, and if we were to announce them in the papers, we would be arrested. Such things will not occur in the United States. In Canada, anyone returning to Japan can carry with him only $\$ 25$ to $\$ 50$ which is spending money on board the boat. As reason for travelling to Japan, if you say for medical reasons, the authorities would reply back that there are doctors here. If you say for educational reasons, they would reply that Canada has schools also. Somehow or another, we are allowed to go to Japan, but we cannot carry money back.

On November 7 a reception for the overseas representatives was held at Koyoukan in Shibuya. My father, Gosuke Hachitani (an overseas representative who was residing in Tokyo), and 30 others attended. ${ }^{14}$ Twenty-four representatives of Japanese residing overseas were given special permission to tour the Imperial Palace on November $9 .{ }^{15}$ They entered the palace grounds and proceeded to the vestibule where they signed their names in the visitor's register to wish the Emperor continued good health. In the afternoon, at the Imperial gardens in Shinjuku, they were offered refreshments of tea and cakes impressed with the Imperial crest.

\section{The Two-day Grand Ceremony}

The grand ceremony to commemorate the 2600 th year of the Imperial Calendar was held on November 10, 1940, under government auspices, at the Outer Gardens of the Imperial Palace. It was said that there were a total of

14 (December 1940). Sailing Abroad, 3(12), p. 41. Japan Takushoku [Colonial Association]. See Shibayama,

[Welcoming Fellow Japanese Abroad in the 2600th Year of the Imperial Reign] 1941a, pp. 164-165.

15 Tairiku Nippo, November 9, 1940. 1,500,000 Japanese in all foreign countries. My father recalled: "We 38 (overseas) representatives were selected to participate. I felt a sense of overwhelming honour. I received an invitation from Prime Minister Konoye to be seated with his group, another special honour."

The Emperor, dressed in full army uniform, and the Empress, dressed in western-style attire, left the palace and proceeded to the ceremony site. The Emperor and Empress were welcomed by members of the Imperial family, 
Prime Minister Konoye, and his cabinet ministers before proceeding up the stairs to the ceremony platform. Premier Konoye proclaimed the start of the ceremony. All in attendance stood up and bowed deeply to the Emperor and sang Kimigayo, the national anthem. Premier Konoye then offered sincere congratulatory words to the Emperor on behalf of the hundred million citizens. Then the students of the Tokyo School of Music sang the official anthem of the 2600 th year. Premier Konoye proceeded back down the stairs, and in front of the Emperor, gave three banzai cheers to the Emperor followed by three more banzai cheers from the whole crowd. After a deep bow to the Emperor by all in attendance, Premier Konoye proclaimed the end of the ceremony. ${ }^{16}$

The celebration ceremonies on the second day, November 11, 1940, began at the Hibiya Concert Hall, where the 38 (overseas) representatives gathered at the invitation of Prime Minister Konoye. They proceeded to the Outer Gardens of the Palace at 1pm. My father recalled:

We representatives from foreign countries were assigned front row seats to the left side. To be singled out in this way enabled us to deeply savour the august atmosphere of the Ceremony!

The celebrations began in the presence of their Imperial Majesties, the Emperor and Empress, with opening remarks by Prince Mikasa, the Emperor's youngest brother. During the singing of Kimigayo, by the 50,000 people who were given the honour to attend, Prince Takamatsu proceeded to the Emperor and read the congratulatory message. US Ambassador Grew, representing the foreign delegation, then read the delegation's congratulatory speech.

The Emperor's words of appreciation were carried on loudspeakers to all those in attendance. Thereafter, the ceremony moved to the banquet phase. With cups of sake provided, the attendees raised their cups to toast the Emperor. Everyone, including the Emperor and Empress, ate the box lunch that was prepared and provided for the occasion. The contents of the lunch box, including the Emperor's, were the same as that used by the army in the field. Entertainment followed, ending with the singing the "26ooth year anthem" by a choir of 3,000 students selected from all parts of the country. After the singing, Prince Takamatsu together with the rest shouted 3 banzai cheers to the Emperor. Premier Konoye then proclaimed the end of that day's ceremony. ${ }^{17}$

Emperor Hirohito was an advocate of peace, especially with the United States. Among his many duties, the Emperor was the commander of the armed forces. The army relegated the Emperor to his ceremonial role, told him nothing of their plans and held Imperial conferences without the Imperial presence.
16 Tairiku Nippo, November 9, 1940; November 11, 1940.

17 Tairiku Nippo, November 11, 1940. 
18 Hoyt, 1992, p. 118. See also Bix, 2000

19 Tairiku Nippo, November 13, 1940.

20 Kishu Nippo, November 30, 1940. For a discussion on racial discrimination against Japanese Canadians see Ward, 1978, pp. 97-117.
Realizing what was happening, he took a more active role. The morning after the second day of celebrations, "the national newspapers announced with awe that the Imperial family had eaten precisely the same food as the commoner." The army justified this action by saying that "the Emperor was truly fulfilling his function in life, exhorting the people by example."

Hirohito issued an Imperial Rescript to mark the occasion.

It is our earnest hope that peace will be restored soon and that we may share with all countries happiness and prosperity, even though the world is now in the midst of great turmoil.

Had these words come from any other source, the person would undoubtedly have been arrested under the new laws against improper thoughts. As it was, no one in the power of government paid the slightest attention to the words of the Emperor. ${ }^{18}$

On November 13, 35 representatives from North America, Central \& South America, Hawaii, East Asia, and South Pacific were invited to the residence of Prince Higashikuni in Azabu. Each representative, including my father, briefed the Prince on the various activities in their respective countries in which they were engaged. The Prince thanked the group for coming, wished them well, and asked them for their continued friendship. Later the group was offered refreshments and left the residence honoured and moved. ${ }^{19}$

On the afternoon of November 28, my father spoke to the Gobo Assembly in his hometown in Wakayama Prefecture. Rather than giving a prepared lecture, he gave an informal talk about the current European War, the drafting of Japanese Canadians and the strong discrimination against Japanese Canadians. ${ }^{20}$ The local newspaper reported:

From December 1st, Mr. Kagetsu will tour China and Manchuria. About December 17th or 18th, he is scheduled to give a talk via international radio. - Coming to Japan, Mr. Kagetsu has been surprised by the abundance of all material goods throughout the country (despite the war in China). He is eager to relay this message to the Japanese abroad and also to report on the welfare of the soldiers at the front lines. This latter aspect, is the reason for his tour of the mainland. 
On December 24, my father boarded the Hikawa Maru at Yokohama and arrived in Vancouver on January 4, 1941. The next day being a Sunday, he relaxed at home and on Monday resumed his busy work schedule.

One historian described the above events as follows: ${ }^{21}$

They hoped to exchange opinion on overseas development; to bring overseas Japanese up-to-date on conditions in their homeland; to spread propaganda about the Sino-Japanese War; and to inspire the overseas Japanese with the purposes of the new expansionist order in East Asia and the nationalist feelings of Japan. For the Issei delegates from Canada, reading papers, seeing military installations and tourist sights, and receiving awards from the government were thrilling events with great symbolic meaning. At last, Tokyo had acknowledged them. Like their American counterparts, they were deeply moved. One delegate from Canada, Eikichi Kagetsu, told the conference that his compatriots struggled against the harshest and most wicked kinds of exclusion and suppression with a burning love for their own country, Japan. This dual loyalty, harmless as it may have seemed to the North American Japanese at the Tokyo Conference, would soon be viewed in a very different light.

\section{Eikichi Kagetsu Awarded the Green Ribbon Medal}

The Tairiku Nippo reported: ${ }^{22}$

We have received news that Eikichi Kagetsu who earlier was invited and attended the 260oth Year National Celebrations in Tokyo, was honoured by His Majesty, the Emperor, with the Green Ribbon Medal for his tireless efforts in promoting Japanese development over the years.

Yesterday on the 18th (March, 1941) at 5 p.m. an award ceremony was solemnly held at the official residence of Consul Nakauchi of Japan.... After reading the following citation, he presented the Medal to Mr. Kagetsu. Mr. Kagetsu followed with a

21 Roy, Granatstein, lino \& Tamura, 1990, p. 24.

22 Tairiku Nippo, March 19, 1941. 
"Thank You" speech. At a separate room, a reception was held in which a toast was raised to Mr. Kagetsu.

Citation accompanying the Green Ribbon Medal - 8th Order Eikichi Kagetsu:

Early in life, Eikichi Kagetsu sailed to the British Dominion of Canada and engaged in logging and lumber trading business. Thereafter, he has overcome many difficulties and has worked diligently to expand his business empire. Also, he was nominated to the post of president of Kanada Nihonjinkai which he served diligently to lead and guide the local Japanese residents. He is truly a devoted businessman and a model to the general public. In view of the foregoing, we award you the Green Ribbon Medal that was established by Imperial Order, dated December 07, 1881 to recognize your good deeds.

November 1, 1940 (Sign and Seal) Yasumaro Shimojo, Junior 3rd Rank, lst Order of Merit, Director General of Decorations Bureau certify that the above medal was recorded as \#640 in the Book of Decorations.

(Sign and Seal) Yachiho Murata, Junior 5th Rank, 5th Order of Merit. 
TREE TRUNK - MY PILLOW I KAGETSU

154 


\section{CHAPTER 16 \\ Pearl Harbor and Its Aftermath}

1 For first person accounts of that fateful day see Broadfoot, 1977, pp. 57-67.

2 Note: On February 24th, Order-inCouncil PC 1486 was passed. See Adachi, 1976, p. 424.

3 Adachi, 1976, pp. 199-224; Frisby, 1963-7; Granatstein, \& Johnson, 1988, pp. 101-127; La Violette, 1948, pp. 3449; Miki, \& Kobayashi, 1991, pp. 20-41; Roy, 1990, pp. 78-87; Sunahara, 1981, pp. 27-48; Ward, 1978, pp. 142-166.

\section{Pearl Harbor}

$\mathrm{O}$ ur family first learned of the attack on Pearl Harbor when newspaper boys ran up and down the streets shouting "Extra! Extra!" The bombing of Pearl Harbor by the Japanese navy on December 7 eventually changed the lives of all Japanese Canadians living on the west coast of Canada. ${ }^{1}$ At the dinner table on that fateful day, my father made sure I knew that we were loyal Canadians. I was 10 years-old at the time. The next day at school, three of my friends came up to me and asked "What would you do if a Japanese plane flew over Vancouver?" I told them that I would shoot it down. They put their arms around me. For them nothing had changed.

On February 26, 1942, the Canadian government announced that "all persons of the Japanese race" must leave the "protected area" - the area west of a line drawn essentially 100-miles inland from the coast. ${ }^{2}$ The government stripped Japanese Canadians of their rights as citizens of Canada. There were no acts of disloyalty. The Canadian army stated that Japanese Canadians did not pose "the slightest menace to national security." This action by the Canadian government has been analyzed and discussed widely since the end of the war. ${ }^{3}$

Other measures included a curfew from sunrise to sundown, the confiscation of cars, cameras, firearms, and radios, censorship of mail, and a ban on 
the purchase of liquor and beer. The forced expulsion of Japanese Canadians from the coast of British Columbia was euphemistically referred to as the "evacuation." On March 4, the British Columbia Security Commission (BCSC) was established to implement the uprooting and "to provide for the housing, feeding, care, and protection" of the evacuees. Austin Taylor, a Vancouver industrialist, was appointed Chairman. F. J. Mead, Assistant Commissioner of the RCMP, and John Shirras, Assistant Commissioner of the BC Provincial Police, were made Assistant Commissioners of the BCSC. A "Custodian of Enemy Property" was set up to hold "in trust," the properties including homes, business assets, and personal belongings of the Japanese Canadians. The government was formulating these policies under the War Measures Act, which empowered the Cabinet to do things by Order-in-Council without the knowledge or approval of the legislature. ${ }^{4}$

At a meeting on March 1, over 100 representatives of various JapaneseCanadian organizations elected a small advisory committee to work with the BCSC. The committee of 15 Issei, including my father, and 10 Nisei, was set up to protect the safety and welfare of the Isseis, Niseis and resident aliens. ${ }^{5}$ This advisory committee was later enlarged to include 150 Isseis and 35 Nisei representatives from various segments of the Japanese population and geographic locations. Tsurutaro Kagetsu represented the Japanese from Fanny Bay. ${ }^{6}$ Priority was given to the removal of Japanese from coastal areas such as Prince Rupert, Ocean Falls and Vancouver Island, and to move them to a "staging area" in Vancouver.

Hastings Park, the home of the Pacific National Exhibition, was chosen to temporarily house evacuees until sites could be found and housing could be provided outside the "protected area". The Livestock Building was converted from an animal to human shelter for women and children in only seven days. The facilities were crude, rows of bunks had been erected, each equipped with a straw mattress, three army blankets, and a small bolster. Each bunk was separated from its neighbor by only three feet of concrete floor, which reeked of the animals that had recently been kept there. Toilets were open troughs and forty-eight showers had been hastily installed. Eating facilities were equally crude-an army field kitchen hastily erected in the former poultry section of the Livestock Building. ${ }^{7}$
4 Adachi, 1976, pp. 217-218, 419-420.

5 The New Canadian, March 3, 1942; British Security Coordination, 1942, pp. 45-48.

6 Adachi, 1976, p. 239; British Security Coordination, pp. 46-48.

7 Sunahara, pp. 55-59; Ito, 1994, pp. 284-295; Miki, pp. 24-27. 
In September 1942, 3,866 persons were living in the confines of the park. There were many problems: lack of privacy, unsanitary handling of food, lack of recreation leading to gambling and drinking, lack of proper schools for children, separation of families, and the constant anxiety of what lay ahead. From March to November, 1942, 8,00o men, women and children were confined in Hastings Park. ${ }^{8}$ Towns outside the "protected area," that had empty buildings were used to house internees. In addition, a number of other sites, including abandoned mining towns, were hastily prepared to receive the relocated Japanese Canadians, and "ghost town" was added to the Japanese-Canadian vocabulary. Everyone had to pay for their living expenses and for any improvement to the bare minimum housing provided.

\section{Fanny Bay}

After war was declared against Japan by Canada and the United States, wartime conditions prevailed. Fuel for operating equipment was not available after January 4, 1942. This caused operations to be limited to half capacity. Dynamite used for building railroads was no longer available to Japanese businesses. Later, possession of explosives by persons of Japanese descent was banned and any dynamite at Fanny Bay was confiscated. On March 9, the RCMP ordered a total of 60 men -27 men from the Fanny Bay camp, 13 from Cumberland, and 20 from Royston - to leave Vancouver Island the next day, and to move to road camps at Thunder River and Blue River. Yoshio Murakami related the following account: ${ }^{9}$

One day when I returned from work, a Mountie (RCMP) was at the Fanny Bay camp and told me that they are moving men who were not Canadian citizens and who were considered a security risk because of their age. The Mountie told me that I could only take one suitcase and that I would have to move the next day. I protested that I couldn't pack by then and they did give us additional time to get things in order. My wife and two young sons were left behind and were moved later.

When we arrived in Vancouver, Hastings Park was not ready to receive us. We were told to go and find our own accommodations. Mr. Ito and I found a Japanese boarding house on Powell 
Kagetsu) came and I went to stay at your home. Later, I returned to Powell Street to be with the rest of the group.

I was then sent to a road camp at Thunder River. They were not ready to receive us. Our accommodations were beds placed in empty box cars on the railway siding. There was no food. We started to build our own camp as there were no facilities there. During this time, my wife and children were moved to Hastings Park together with your uncle's family. Then it was decided that we would move to Minto with your father and uncle. I returned to Vancouver but was not admitted into Hastings Park. Your uncle and I stayed at your father's office on Princess Avenue for a while.

With the loss of 27 workers, work had to be suspended. Within the next week, available Niseis in the vicinity were hired and work resumed. Efficiency was reduced because of the inexperienced workers and because the uncertainty about relocation was unsettling and worrisome. On March 22, orders were received from the RCMP for all Nisei and naturalized citizens to leave the "protected area." These were anxious times for everybody.

Upon hearing that all persons must evacuate, my father wrote the following letter in English to the Mr. Austin C. Taylor, Chairman, BCSC: ${ }^{10}$

\section{Dear Sir:}

- I own a logging operation and have now in the woods, timber felled to the extent of 2,500,000 feet log measure. Should these logs not be removed before this summer, damage from insect attack will make the products almost valueless. On the other hand continued logging will result in marketing to eager buyers, the chief of whom being H.R. MacMillan interests.

- I wish to respectfully request, therefore, that through your thoughtful consideration special permission be granted to twentythree (23) men either Nisei's or naturalized Canadians so that I may hire them for two months to complete the operation. In return for your kindness, I am willing to accept full responsibility for the hired persons and shall employ them only on condition that upon expiration of their permits they obey whatever is ordered by your commission. - 
I greatly realize the value of your time and that people are constantly presenting their personal problems to you but your favorable consideration to the above will be immensely appreciated.

Sincerely yours, Signed E. Kagetsu

No reply came to the above-cited letter. Mr. Etsuji Morii conveyed a message to my father that permission was not granted.

The orders of March 22 were not implemented immediately. On April 8, the orders were reissued for all Nisei and naturalized Japanese Canadians to relocate outside the "protected area." All work ceased immediately and workers were engaged in shutting down machinery and equipment, and in moving them to areas safe from fire hazards. In addition to closing down the camp, my father felt responsible for all his employees and families, including the wives and children of the Japanese nationals who were moved earlier in March. He noted in his diary that there was "so much to do!" When my father returned home to Vancouver from Fanny Bay in early April, he was not permitted to return to Vancouver Island. On April 14, they were notified that they would all be evacuated the next day.

A reporter from a local newspaper described the departure, on Wednesday morning, of 586 Japanese on board the S.S. Prince George from Union Bay as follows: ${ }^{11}$

Ten minutes after ten o'clock the three funneled battle gray exC.N.R. luxury liner, now employed on His Majesty's occasions in Pacific Waters, slid slowly back from the government wharf and backed out into the waters of Baynes Sound before proceeding on its way to Vancouver. On board it were all the Japanese of the Comox district from Oyster River to Fanny Bay, who have been living here, with the exception of some eight or nine individuals who are helping the official custodian to close out estates and check property.

- one family from Fanny Bay had not arrived. A permit had been obtained for an official of the Deep Bay Logging Company to stay over to help arrange for the transfer of that property: he thought this included his family. -

The RCMP constable had to go and notify the family and get 
the Island Highway. At last it came and the mother and her six children were checked on board, the whistle blew, the ropes were thrown off only ten minutes behind zero hour.

Eight buses had been commandeered from the Vancouver Island Coach Lines to bring the evacuees from their homes in Cumberland and Courtenay, Fanny Bay and other points to the port and these unloaded their human freight methodically long before the hour for departure came. They streamed on board: old men who had lived on the Island for 45 years and never been off it since they arrived, and babes in arms, young men and women who knew only the Island as their home. No heavy freight was allowed, but they came loaded with their household goods. It had been ruled that there should be one large package of bedding and the household goods from each family: but that had been construed in some cases as one for each individual .... However-it was passed; but what a mountain of it there will be at Hastings Park!

The "mother and six children" were my aunt and cousins. The ship arrived at the CNR wharf in Vancouver where they were transferred to Hastings Park, escorted by the RCMP. Tsurutaro Kagetsu and Nishi remained at camp to close up. My father had to get a special permit to visit his brother's family at Hastings Park.

On April 16 my father received orders to hand over all the machinery and equipment of the Deep Bay Logging Company to the BCSC. Earlier, my father had submitted a complete list of the assets that included over 7,000 acres of prime timberland, 9.5 miles of railroad, a locomotive, 19 flatcars, 4 "donkey" engines, 2 tractors, 24 camp buildings and assorted tools and equipment. He was given a special permit to go to Fanny Bay to turn all his business assets over to Mr. Wray and Mr. Murray of the Custodian. The transfer was completed by checking off the items on the list. All machinery and equipment had been stored properly, and both men made comments that they were impressed. My uncle Tsurutaro and Mr. Nishi remained on site until the Custodian sent over their own watchman.

After the transfer was completed, my father boarded a stagecoach to Nanaimo to catch the ferry to Vancouver. He no longer had a car and had to travel on public transportation. He sorrowfully wrote in his journal, "With this, I will have to temporarily sever my bond with dear old Fanny Bay, long my business home." 


\section{The University of British Columbia}

During World War II, universities across Canada required six hours of military training on campus per week. On January 2, 1942, after Pearl Harbor, the Senate Committee on Military Education at UBC passed a motion instructing Commanding Officers that Japanese-Canadian students not be permitted to take part in military training at the university as of January $5,1942 .{ }^{12}$ Sixty Japanese-Canadian students were ordered to turn in their uniforms when they returned to the university after the Christmas break. My brother Hajime, a fifth-year forestry engineering student and president of the UBC Japanese Students' Club commented, "I didn't think the university would do a thing like that!" On January 8, Hajime and Peter Yamada met with President Klinck and Lieutenant-Colonel Shrum to protest against this action. Klink and Shrum stood by the position taken by UBC. ${ }^{13}$

The editor of Ubyssey, UBC's student newspaper, solicited the following statement from the president of the Japanese Students Club: ${ }^{14}$

The Editor, The Ubyssey

\section{Dear Sir:}

We, the young Canadians of Japanese descent more than any other group had hoped and prayed that a war between Great Britain and Japan would never be fought. Yet, last month our fears suddenly became a grim and tragic reality. Some find it difficult even yet to fully realize that a major war on the Pacific is now a fact.

The loyalty of Canadian-born Japanese is constantly being questioned. Some suspect us of absurd fifth column activities, making reference to the treachery reported in Hawaii. It is indeed unfortunate that newspapers emphasize only the hideous aspect. Too many have not been informed that the defenders of Hawaii, gallant as they were, consisted of not only Americans but nativeborn Japanese as well. To some things we raise little objection because we realize that although unfavorable to us certain precautions must be taken. However, upon hearing unjust and uncalled for views we naturally feel quite indignant. The lack of logic in branding individuals as disloyal merely because of racial stock surely is obvious ... 
We leave avowed unflinching allegiance to Canada and have continued to respond most enthusiastically to every mentionable patriotic campaign. Had it not been for restrictions, scores would now be in our armed forces to join the few who have already been admitted. Our endeavor is to fulfil our obligation and gratitude to Canada. To be honest, however, there is something further, namely our realization that a decent livelihood is possible only in a democracy. Where else would one find, especially during critical moments so much thoughtfulness, tolerance, and friendliness as we enjoy in America? Certainly not under totalitarianism.

Hajime Kagetsu

The Ubyssey carried editorials and letters to the editor that debated the "Japanese problem." UBC's action against the Japanese Canadians was not opposed by faculty or students. There are indications that within the university, the pressure from the public in general was of major concern. However, after the January 20, 1942 issue of Ubyssey, there was no further discussion about what to do with the Japanese Canadians. ${ }^{15}$

The editor of The New Canadian, Tom Shoyama, wrote: ${ }^{16}$

No doubt the action of University authorities in dismissing Canadian-born Japanese students from military training at the University will be received with approval in certain quarters. And no doubt, too, that action will shelter the University from "criticism" that might have been directed against it in "letters to the editor" columns. Perhaps, too, the University authorities, now that they have thus solved a "ticklish situation" will find vast comfort in taking refuge once again from the stormy blasts of the outside world within their cloistered halls of learning.

Personally, for the first time since becoming a part of the University, the editor of this paper is ashamed of the institution which once commanded all his honour and respect. One can forgive the aged Galileo, in fear of torture and eternal damnation, bending low in his recantation. But can one forgive the University, symbol of truth and enlightenment, thus cravenly prostrating itself before the fear of an untested "downtown" criticism.

There is a larger issue implicit in this situation. Here at the University, was a group of Canadian-born citizens, so Canadianized in outlook and education, so aware of Canadian ideals and tradi-
15 The Ubyssey, January 9, 12 \& 20, 1942; Bernard, pp. 41-45.

16 Editorial, The New Canadian, January 7, 1942; Bernard, pp. 39-40; Ito, 1984, p. 41. 
tion, so deeply obligated and cognizant of their obligations to Canada, as to provide a test tube experiment in loyalty and citizenship that had no chance for failure. And thus thrown away is a splendid opportunity, not merely to secure the hands and brains of a small group of trained students zealously contributing to Canada's war, but also to rally solidly and effectively behind them the whole of the Japanese population in Canada.

On February 14, the Japanese Students' Club held a St. Valentines dance that was attended by more than 100 couples. The dance raised $\$ 50$ for the War Aid Fund. Hajime Kagetsu, President of the Club stated that by endeavours such as these, the Japanese Students' Club hoped to be able to prove its loyalty to the war effort.

Ten days later, the Canadian government ordered the evacuation of all persons of Japanese ancestry from a 100-mile wide zone along the coast of BC under the supervision of the BCSC. The International Student Service (ISS) committee of the World Aid Council was concerned that the immediate removal of Japanese-Canadian students would prevent them from writing the final examinations. The ISS, a worldwide organization with headquarters in Geneva, undertook to minimize the disorganizing effects of war upon student life in every possible way. The president of the ISS committee wrote a letter to the BCSC requesting that Japanese-Canadian students be allowed to complete their present year's work. ${ }^{17}$ The ISS contacted my brother Hajime, as President of the Japanese Students' Club, to offer their assistance in placing JapaneseCanadian students in other Canadian universities. ${ }^{18}$

The BCSC granted deferments to allow the Japanese-Canadian students to complete their course requirements and to write the final examinations. Of the 72 Japanese-Canadian students enrolled at UBC for the 1941-42 session, 14 graduated, including my brother Hajime who received his Master of Applied Science degree in forestry engineering. ${ }^{19}$ All graduating engineering students took part in a secret "Kipling" ritual, similar in principle to the "Hippocratic Oath," taken by medical doctors. During the ceremony, each new engineer was presented with an iron ring that is symbolic of the profession in Canada. My brother was given his ring, but advised not to attend the ceremony. Hajime never wore his iron ring. ${ }^{20}$

A number of students who had previously attended UBC wanted to attend universities outside of BC. On August 1942, "certain universities inquired into the Government's attitude on the admission to universities, in other parts of Canada, of Japanese evacuated from British Columbia." At the Cabinet War 
Committee on September 9, 1942, it was "agreed that the question was one for the universities themselves to decide, and that the government should adopt no official attitude in the matter." ${ }^{21}$ Japanese-Canadian students were not allowed to return to UBC until 1948.

\section{Security Risk}

The intelligence on Japanese Canadians was not very good. ${ }^{22}$ The British Security Coordination (BSC), located in New York City, was set up by William Stephenson, whose code name was Intrepid. He established a worldwide intelligence network and reported directly to the Prime Minister of Great Britain, Winston Churchill, and to US President Franklin D. Roosevelt. Intrepid's accomplishments helped change the course of World War II. ${ }^{23}$ When war was declared on Japan after Pearl Harbor, the BSC was concerned with Hemispheric Defense. On June 2, 1942, they issued a report, entitled Report of Japanese Activities in British Columbia, which presented their evaluation of the Japanese Canadians on the west coast of Canada. ${ }^{24}$ Stephenson sent this report by courier to Commissioner S. T. Wood at the RCMP headquarters in Ottawa. ${ }^{25}$

The introduction in the report states that the "Japanese have created an elaborate and far-reaching organization for espionage and subversive activities," and that measures taken to counteract subversive activities were inadequate. One concern was the sale of explosives to Japanese. Japanese firms like the Deep Bay Fishing Co. Ltd. (They meant, Deep Bay Logging Company) and the Cameron Lake Logging Co. Ltd. were able to purchase dynamite as late as December 18, 1941.

In conclusion the report suggests that: ${ }^{26}$

$\ldots$ in view of the facts reported, certain steps require to be taken at once. Brief records of a number of suspects have been given in Appendix 10. It is urgently suggested that those in Class A be arrested immediately and simultaneously. It is necessary that they be taken up one by one and held without the means of further communication.

They should be interrogated individually by those acquainted with the Japanese mentality and if possible, the Japanese language. Information concerning the activities of such men as Etsuji MORII, Eikichi KAGETSU, Teigo NORITAKE, Bunji HISAOKA, Charles
21 Memos, Library and Archives Canada, Department of External Affairs Records, File No. 3464-W-40.

22 Granatstein, pp. 101-129.

23 Stevenson, 1976.

24 British Security Coordination, 1942, p. 15.

25 Ito, 1994, pages 207-213.

26 British Security Coordination, p. 15. 
NAKAMURA, and the various organizations with which they are connected will be obtained. In view of the multifarious ramifications of the Japanese network, information of vital importance to the whole defense of the Western Hemisphere may be forthcoming.

In Appendix 10 of the report, there were 35 names in Class A of which the first 16 names included the most prominent men in the Japanese community. My father's name was second on the list and the report on him is reproduced in Appendix IV. This is a remarkable report on my father by the BSC, not for the in-depth analysis of the facts, but for the manner in which my father's loyalty to Canada was questioned and misstated. It implied that my father was a subversive because of his association with men listed in Appendix 10-who were interned and were sympathetic to Japan - and because of his love for the land of his birth and relationship with Japan and things Japanese.

My father had a joint venture with Mitsui interests, but he was never their representative. He was suspect because he lent or gave money to small Japanese businesses, numerous individuals experiencing hard times (especially if they came from the same home prefecture in Japan), organizations in Canada and Japan, and to students. The report ignored the fact that he contributed generously to Vancouver civic drives and to the war effort when war was declared against Germany. He gave financial support to The Canada Daily News because it was moderate in its views and because the editor, Mr. Juzo Suzuki was his friend. He "was closely associated with Dr. Chikao Hori" because he helped pay for his education. Besides giving a major donation to the building fund for the new Hompa Buddhist Temple, he lent them funds in 1936 to complete the construction. The report stated wrongly that as a Christian, his support for Buddhist Church was suspect. Practically every one knew that my father was a devout Buddhist.

Commissioner Wood of the RCMP responded to Mr. Stephenson on August 5, 1940, with a report by Sergeant J. K. Barnes, who was in charge of the RCMP Intelligence Section in Vancouver. Commissioner Wood wrote: ${ }^{27}$

I do not mean we should take the action suggested by the agent in arresting these persons mentioned by him as suspects. As many of these people are Canadian citizens, we could not produce the evidence necessary to justify our actions, which, as you know, are subject to a board of review, and the police are compelled to support their action by evidence before such a tribunal. 
We have had no evidence of espionage or sabotage among the Japanese in British Columbia. The situation has changed considerably since the report was written, and most of these people are now in isolated areas outside the protected area, and those at present in Vancouver will be moved by November next.

There was no question in my father's mind of his loyalty to Canada, his adopted homeland. He was neither interrogated nor interned. Only one of the top sixteen on the list was sent to an internment camp. It is hard to believe that a prestigious organization such as the British Security Coordination would write a report full of errors, misdirection, and exaggerations. It is a credit to the RCMP that they acted with restraint and understanding. The naturalized Japanese Canadians born in Japan, Issei, and the Canadian-born Japanese, Nisei, were proved to be loyal Canadians.

\section{Life in Japan}

Takako and Hiroshi decided to stay in Japan despite the signs of an impending war. At the Nihon Joshi Daigaku (Japan Women's University), Takako took a course which was not led by a teacher, but the students reflected on various topics. When the war broke out, the discussion revolved around the war. During the first two months, Japan was winning all the battles. However, one girl said:

Everyone is talking as if we are going to win the war. We can't assume that. We have to think what would happen in the worst situation if we didn't win the war.

Those words really sank in and Takako thought to herself, "This girl is my girl." Takako's classmates almost forgot that she was a foreigner. She never rocked the boat. She had to report every month to the authorities.

When the war broke out, Takako's class was given their graduation diplomas in December 1941. Those who could stay, including Takako, stayed on in school until March 1942, the end of their senior year. While Takako was still a student, she was invited to the NHK national broadcasting station because her English was so good, and went to audition for a job to broadcast in English. She did some translation work for the Ministry of Education (Mombusho) at the uni- 
28 Niija, 1993, pp. 148-149; The New Canadian, July 7, 1848; September 8, 1948.

29 For a description of post-war conditions in Japan, see Dower, 1999

30 The New Canadian, January 5, 1949. versity, and didn't want to spend time travelling to the studio. She declined the job offer. Others accepted the job. One of them was Iva Toguri, an American, who became known as "Tokyo Rose." After the war, she was convicted of treason in the United States, but later was pardoned by President Ford. ${ }^{28}$

Takako then became an instructor of English and also did tutoring. She continued to live in the dormitory until the incendiary bombs started to fall on Tokyo-the first city to be hit. Each family went to their designated air raid shelter. Yokohama was considered a safer place to live during the bombing raids. Takako moved to Yokohama and stayed with a family named Saito. Dad knew Mr. Takenosuke Saito, who was a Mitsui official. Within a few months, Yokohama was also bombed. When the Saito's home was hit by a bomb, Takako's prized possession, her typewriter, was destroyed.

Mr. Saito had parents in the near-by prefecture called Saitama and it was decided that they would all move there. While in Saitama, Takako occasionally went to Tokyo to visit her school. Her department head wanted her to keep in touch so that Takako could get her old job back when things got back to normal. The war ended in August 1945 and everyone knew that MacArthur was coming. ${ }^{29}$ Takako's department head said that the Ministry of Education needed to have all the Japanese textbooks translated into English and offered her the job. Takako agreed to do it and brought the textbooks with her to Saitama and translated them there. She did this work until a friend got her another translation job in Osaka with the US Army.

In Osaka, Takako worked for the Censorship Detachment, Press, Pictorial, Broadcast Section (CCD,PPB) in the Press Department. Nisei who were repatriated from Canada were assigned to the Postal Group that censored mail that was not too difficult to translate. Many of the repatriates were teenagers. They also filled clerical jobs. In 1949, 40 girls and 34 boys who worked for the Americans sent "Greetings from Canadian Niseis in Osaka, Japan."30 Among the boys' names was Yoshio Nishikawa, a friend of mine from the Fairview Japanese School in Vancouver. Takako in one of her letters mentioned that she had met him in Osaka.

At that time, the Central Intelligence Corps in Osaka consisted of men only, but made an exception and hired Takako because she had better qualifications. There were two shifts. Men selected what articles they wanted translated. Takako was about five times faster than the others and was assigned the job of editing the translations before they were typed. In late October 1949, the CCD was closed. They graciously said that they had worked themselves out of a job. In the meantime, Takako applied to regain her Canadian citizenship. She lost it when she had chosen to live in Japan during the war. She returned to Canada 
in December, 1950. From the end of the war to her return to Canada, Takako was finally able to spend time learning the culture of Japan. There were hardly any Nisei attending college in Japan. Takako was one of the few Niseis in her generation who graduated from a Japanese university and then came back to Canada.

Hiroshi was not allowed to graduate and was drafted along with other university students. He was conscripted into the Japanese Army intelligence because his English was good. He translated intelligence data. When the war ended, he was very concerned about how the Allies would consider his work in the Japanese Army. Evidently, no problem developed. After the war, Hiroshi got a job as the manager of an Officers Club in Yokohama. His superior was a lady who had much experience in running a hotel. She was good to Hiroshi and taught him much about this business. Eventually, he moved on to a better paying job as an office manager for an exporting company. 
CHAPTER 17

Our Lives are
Changed Forever

\section{The Move to a "Ghost Town"}

1 Vancouver Sun, February 15, 1958.

- or Japanese Canadians, "ghost town" is the place (e.g., Greenwood, Kaslo, - Minto, New Denver, Sandon, and Tashme) outside the "protected zone" in the interior of British Columbia to which they were relocated. This forced expulsion of Japanese Canadians from the coast of British Columbia was referred to at the time as the "evacuation." Most Japanese Canadians believed that they would return to their homes and work when the war ended.

Bridge River, a tributary of the Fraser River, flowed swiftly southward at the base of the mountain on the west side of the valley. A dirt highway ran along the base of another mountain on the east side and wound its way northward past Minto Mine to Bralorne, a world famous gold mine partly owned by Austin Taylor. Warren A. Davidson built a town site about a mile up the highway from the mine. There were neat rows of houses on both sides of the highway, on two streets parallel to the highway that were intersected by a side street. At one of the corners on the highway, a general store, the only store in town, and the post office occupied the ground floor. Apartments occupied the second floor. Minto Hotel with 15 rooms, stood across the side street.

The rich ore vein of gold in Minto Mine, which opened in 1934, petered out and by 1942 the mine was closed. ${ }^{1}$ Minto was selected as one of the "self-sup- 
porting sites" to which Japanese Canadians were relocated. The term "self-supporting" meant that each family paid for their own transportation and transfer of belongings and therefore were not limited in the amount of possessions they took. In addition, the families had to pay rent for their housing and all living expenses, including food. They had to live off their savings and therefore only the wealthier families could afford to live at a "self-supporting site."

The remaining residents of Minto were moved to nearby Goldbridge, except for Mr. Davidson who owned most of the houses and his housekeeper, Mrs. Wiles, who was also the postmistress. The first group of Japanese families arrived in Minto in early May 1942. ${ }^{2}$ By June 21, "evacuees" in Minto numbered over 300 persons.

On April 24, my father sent Mr. Toshiji Nishi to check out Minto. His report must have satisfied my father, who decided to move to Minto. On May 8, my father shipped items of furniture, boxes of food items, and other necessities to Minto via Pacific Great Eastern (PGE) freight. On May 11, the families of Tsurutaro Kagetsu, Yoshio Murakami, and Mr. Suenaga, from Fanny Bay, left for Minto. My father rented our Vancouver home and its "contents" to the Milligans, our next door neighbors, for the "duration of the war." They eventually sold their home and moved into our house. Our summer house was rented to my father's lawyer, Mr. Carl Stewart.

Early on the morning of May 28, our family and others assembled at the Union Steamship pier. The ship departed at 12:30pm and arrived at Squamish at 3:40pm. Everyone was transferred to a PGE train that transported them to the town of Bridge River at midnight. Our family spent the night at Shalath Lodge, while most of the other families spent an uncomfortable night trying to sleep on the train. At $8 \mathrm{am}$ the next morning, we boarded a bus for Minto. The road had many dangerous spots as it went over Mission Mountain, which stood at an elevation of 4,000 feet. We descended approximately 2,000 feet and arrived at Minto two hours later. Hajime had arrived earlier and had cleaned up a temporary home so that we could settle in immediately. This house was one of the nicest in town. It was separated from the other houses on the side street off the highway. It was spacious and appeared to be fairly new. However, the house was located on the old river bed and the land was covered with round boulders with no soil for a garden.

The heads of households held a meeting to discuss the classification of houses. Our temporary home was graded as class A, and as such had a high rent. On June 23, my father decided to move to an old two-storey building on the highway that used to be a Chinese laundry. The outside was unpainted and the wood siding was severely weather beaten to various shades of brown. 
Mr. Suenaga and Mr. Watada did the carpentry work such as putting in a new wood floor, a Japanese bath, and repairs. Tsurutaro Kagetsu, Yoshio Murakami, Toshiji Nishi, and Mr. Tamaki helped clean up the house. Also, a group of these men put up white wallpaper in the entire house. One day when we were almost ready to move in, a group of men arrived carrying a wooden structure. It was an outhouse! It was set about 30 feet from the house. Work on our new home was completed on July 24 . The next day, with a rented truck and with the help of many people, we moved into our new home.

\section{Schooling}

Schooling was a top priority for the parents, especially since the 1941-42 term was cut short by the "evacuation." Although the British Columbia government was responsible for public school education, they did not do anything for the Japanese-Canadian community - they had to make their own arrangements. ${ }^{3}$ There was a one-room schoolhouse in Minto. Grades 1, 2, 5, and 6 were taught by Mrs. Kaz Umemoto, a Normal School graduate. Grades 3, 4, 7, and 8 were taught by George Tamaki, a lawyer. Grades 1 through 4 attended school in the morning and grades 5 through 8 attended class in the afternoon.

Kaz Umemoto recalled: ${ }^{4}$

We were told that we could use the text books and whatever supplies there were in the school house. I found the Curriculum of Studies and made preparations for the classes.

It was difficult to prepare for the classes with so few supplies. We had to be resourceful and creative.

I can still see those eager young faces entering the classroom for the first time and the older children actually anxious to resume their studies. The children helped by being attentive and eager to learn. They behaved well so there was no discipline problem, not as in present times. Also, the parents were very supportive and met our requests when asked.

We concentrated and crammed all the requirements into

3 Moritsugu \& Ghost-Town Teachers Historical Society, 2001, pp. 2-3.

4 Kaz Umemoto (Letter to Jack Kagetsu, May 8, 2001). those three short hours. There were no facilities for frills. In the long run, they did remarkably well and were ready to continue in other schools without missing a beat. 
I was in the sixth grade. When I finished an assignment early, it was interesting to see what the other grades were doing. The teachers coordinated their lessons so that only one teacher was speaking to her/his class at a time. Later, a partition was built so each teacher had a separate room with two classes. Akira, my brother, who was in grade 9 , had to take a correspondence course. $\mathrm{He}$ found it difficult to study by himself.

\section{Life in Minto}

There was running cold water in the kitchen. We had our refrigerator from Vancouver. At first, powdered milk was reconstituted. It was not the same as fresh milk. Condensed milk and evaporated milk were used for cooking and baking. My parents made tofu from cooked soy beans. Lye was added during the making of konyaku-that did not appeal to me. Adjacent to the kitchen was a huge copper cauldron that was used to heat water for the laundry. This was converted into a Japanese-style bath. A raised platform was built between the tub and the wall. This is where you soaped yourself and rinsed with water scooped out of the tub. Once you were clean, you stepped into the tub and sat on a seat in the tub-it was very relaxing.

My father always liked gardening. Our new home had a large lot with excellent soil - the previous owner must have cultivated the soil. This was one of the reasons my father chose this house. Our family hurried to put in a vegetable garden as part of the growing season had already been lost. A variety of vegetables were planted together with transplanted seedlings. My father successfully grew a small variety of watermelon that was sweet. Mr. Davidson had a stable of horses. There was plenty of horse manure to fertilize the garden. My father collected the water from the kitchen sink to water the garden. One of my jobs was to water the garden with a hose.

It was new and exciting to watch a horse being "broken in" by one of Mr. Davidson's hired hands. We watched the shoeing of a horse and were given a horseshoe nail formed into a ring. We were allowed to ride the horses. Being young, I was given an old mare that was smart, but lazy. I had to lead it away from the barn, mount it, and get a ride as it trotted back to the barn.

Off the hotel lobby, there was a large room with two pool or billiard tables. This was used as the town recreation hall and as a place where teenagers could get together. On Saturday evenings, a crowd would gather to watch the men play pool. Some of the men became excellent players. During the day, the kids 
were allowed to play. I still remember Jack Watanabe, a tall lanky boy, who was an excellent player.

I sold the Liberty magazine. In the late fall, I took orders for Christmas cards including "personalized" cards with names printed. The boxes of cards sold for one dollar. The number of cards and my commission varied depending on the quality. In the spring, I took orders for seeds. Later in the year, many of my customers told me how well the seeds had germinated and had given them a good crop. That made me feel good. I was the only one who went door-to-door selling things and I am sure there were people who thought "Here he comes again." The money I earned was kept in a tobacco can.

When we were "evacuated," my father bought a small upright piano and had it shipped to Minto with the furniture we needed. Although my sisters could practice, they had no one to teach them. Sachiko gave piano lessons to our cousins Natsuko and Yoshiko and to the Suenaga girls. At home, these piano students had to practice on a cardboard keyboard.

Groceries were purchased at the General Store. Because of the wide variety of goods on display, the store appeared very crowded. Kaz Umemoto recalled: ${ }^{5}$

No best seller was read and studied more avidly than good old Eaton's and Simpson's catalogues, our link to the outside world. Much of our needs were filled from the mail-order catalogues.

There were no medical facilities or practitioners in Minto. Our neighbor developed a high fever. The kids were asked to find earthworms. I'm not sure how they were used. Probably the worms were boiled and the patient was given the liquid. In any case, he recovered. When my mother had a serious problem, Dr. Miyazaki came from Bridge River-another area to which self-supporting Japanese from the coastal area were moved. ${ }^{6}$ Luckily, very few serious medical situations developed.

At the beginning of August, my sister, Kimiyo, got part time work at the Minto Post Office. Mrs. Marguerite Wiles ran the Post Office since the town started. Kimiyo was invited by Mrs. Wiles to join Mr. Davidson and others on a hunting trip. They filed past our home on horseback with their supplies and camping gear. I think they bagged a deer or two. I tasted venison for the first time. I don't think it was cooked properly as it had a strong, gamy taste. In the fall, a group that included our parents, our uncle and aunt and some of the kids went hiking in the forest to look for and to pick matsutake mushrooms that were abundant in Fanny Bay. We were taught how to search the base of fir 
There were many dead trees by Bridge River that provided firewood. Able bodied men helped my father carry the logs over half a mile to our home. My father had a crosscut saw from his logging camp and we all learned to saw the logs into short pieces. The big pieces were split with an axe or with wedges and a sledge hammer. Adjacent to the house, there was a large, covered storage area for the firewood. In the living room, there was a potbellied stove in which wood was burned to heat the house in cold weather. The kitchen stove also required wood for cooking the meals. My father was pleased with the vegetable garden which he tended daily. He recalled that the vegetables grew very successfully and that people especially admired the cantaloupes and honeydew.

At first, we were not allowed to have a radio. There must have been some in Minto because Mr. Kawata came every day to deliver the latest news about the war to my father. My oldest brother, Hajime, was able to complete his Master of Applied Science degree in foresty engineering at UBC and was permitted to delay his move from Vancouver until convocation. He and Tom Tamaki applied to Queen's University in Ontario, and in September, they got permission to move to Ontario. To celebrate his departure, my father had a dinner at our home and invited Mr. Davidson, Minto's "Mayor," and the provincial police officer, Mr. Johnson. On September 10, 1942, Hajime and Tom took the stage coach to the train station, and caught the train that transported them east. Hajime sent my brother a subscription to the Captain Marvel comic book and I got Superman. For us, that was a great present!

Our first winter was severe. On November 2 we got our first snowfallabout one foot. Snowfalls of one or two feet were common. The coldest day registered a temperature of minus 40 degrees Fahrenheit! However, it was perfectly still and so there was no wind chill effect. Also, the air was very dry. We learned quickly to guard against frostbite. The water main would freeze. The young men in town had to locate the frozen section, dig it up, and attempt to thaw the blockage. Going to the outhouse was a chilling experience and the "night bucket" was appreciated. The only good thing was that there were no flies or odour.

On January 12, 1943, Mr. Stewart, my father's lawyer, came to Minto from Vancouver to discuss matters regarding my father's logging business. My father had a strong relationship with E\&N Railway that sold timberland to him at Fanny Bay since 1923. There was an understanding between them that the adjacent timberlands owned by the E\&N Railway, representing many years of logging into the future, would be reserved for my father. According to Mr. Stewart, the E\&N Railway sold this timberland-yielding between 25,000,000 board feet to $30,000,000$ board feet to Mr. Koerner, owner of the John Locke 
Logging Co. This was a major loss because the business was worthless without the additional timberland.

My father obtained permission from Mr. Johnson, the provincial police officer, to visit friends and former employees at various "evacuation centres." $\mathrm{He}$ left Minto on April 14, 1943 on the stage coach to Bridge River, and made his way to Lytton where he caught a train to Chase, $\mathrm{BC}$ to visit Mr. Momose. He then visited Mr. Sadao Maikawa in Revelstoke and then went on to Kelowna, where he visited a number of friends and went sightseeing. He had a happy time at Tashme where many of the Fanny Bay "bunch" lived. He arrived back home in Minto on April 26.

On May 24, Mr. and Mrs. C. Stewart came to discuss selling timberland at Fanny Bay. My father agreed to sell our summer house in West Vancouver where they were residing for $\$ 3,000$, which must have been close to the purchase price. Later in the spring, my sister Kimiyo left Minto, met Yoshiko Momose and traveled to Toronto. She found a job in the garment industry. Akiko took Kimiyo's job at the Post Office. On July 21, my mother and I boarded the train at Bridge River to visit my sister Kimiyo in Toronto. My parents were concerned about our education and so my mother wanted to determine first hand what the situation was in Toronto. After checking around, she decided we should go to school in Toronto. On August 21, my mother and I returned to Minto by stage coach and on the same day, Sachiko and Akira left to study in Toronto. On September 21, my mother, Akiko, and I left by stage coach to catch a train to Toronto. My father recalled, "Toyo plans to return as soon as a place for the children to live is found." As it turned out, she never got back to Minto.

My father decided to stay in Minto. Now that he was retired, he preferred rural living over the hectic city living. He had his friends, his brother's family, and his garden. He had led a group of families from Fanny Bay to Minto and felt an obligation to see that everyone was taken care of. Once a week, my father invited my uncle Tsurutaro's family to the house. My father sang, recited haiku he had composed, and served homegrown watermelon. My Auntie Hideko would bake an apple pie and bring it for refreshments. Later, when permitted, he purchased a radio and everyone listened to the news. On Saturday evenings, he got together with his friends.

In 1941, my father was at the prime of his life. He had built a successful logging business, was a leader in the Japanese-Canadian community, was highly regarded and wielded great influence in the Buddhist Church. After we relocated to Minto, my father recorded many interesting facts about his life. His last entry dated 1943 read "and later, spent meaningless days." His diary con- 
tained similar feelings during the winter months- "spent idle days," "every day has no meaning," "nothing to do," and "too much time on my hands." For something to do, he started making artificial flowers. He learned this art while working in Osaka during his youth and put it to practical use to earn extra money when he first arrived in Vancouver. He worked on improving the tools he used and on the technique for making the artificial flowers. As soon as the weather permitted, my father would start preparing his garden. Gardening occupied his time during the summer months and he enjoyed the fruits of his labour.

On February 26, 1944, everyone received shoyu, tea, miso, etc., from the Japanese Red Cross, and my father was very grateful. However, a group of Niseis in Toronto refused to accept these gifts because they believed that the Japanese government was trying "to convert our sympathies to its fascist philosophy."7 On August 14, 1945, Japan surrendered. Originally my father thought that as soon as the war ended, he would begin exporting timber to Japan. Since that was no longer possible, he decided to move to Toronto. He finished packing by the middle of September and arrived in Toronto on September 25. 
CHAPTER 18

\section{Meagre Compensation for Liquidated Assets}

\section{Liquidation of All Assets}

he assets of the Deep Bay Logging Co. Ltd., Kagetsu \& Co. Ltd., and personal assets were turned over to the Custodian of Enemy Property by my father before moving to Minto. Also, even though the Ocean Timber Company had been sold, certain items remained to be resolved by the Custodian.

On January 19, 1943, the Canadian government passed Order-in-Council PC 469, which gave the Custodian of Enemy Property the power to sell properties which had been turned over to them to hold "in trust" without the owners' consent. The Custodian became the liquidator. Properties, houses, businesses, furniture, household goods, personal effects, family heirlooms, etc., were sold or auctioned off at a mere fraction of their value. ${ }^{1}$ The Canadian government avoided the requirement under the Geneva Convention to house and feed aliens by stating that Japanese Canadians were relocated citizens. Then the government rationalized the sale of their assets by saying that the Japanese Canadians needed money. The real reason was to eliminate competition in business and industry posed by Japanese Canadians and to discourage their return to the west coast. ${ }^{2}$ On March 1942, G.W. McPherson, the Vancouver representative of the Custodian of Enemy Property, authorized P.S. Ross \& Sons, Chartered 
Accountants, to administer my father's assets and to inspect all books and documents belonging to the DBL. ${ }^{3}$

Before the Custodian was empowered to sell the assets of Japanese Canadians, the Assistant Timber Controller of the Department of Munitions and Supply wrote to the DBL on August 28, 1942 requesting that everything possible be done to resume operations because lumber was "very urgently required for Canadian and United Kingdom Defense work." 4 Five months earlier, my father was denied permission by the BC Security Commission to hire the help he needed to move $2,500,000$ feet log measure of felled timber to the market before it was made useless by insects. The Custodian wanted DBL's assets "disposed of" so that it could be placed in operation. C. M. Stewart, acting on behalf of my father, was not successful in obtaining a buyer nor was the Custodian. ${ }^{5}$

Even though logging operations ceased in the spring of 1942, payments for long term leases for right-of-ways for the logging railway had to be paid. Approximately \$4,500 was owed to the Workmen's Compensation Board and $\$ 2,115$ to the Department of Lands, Forestry Branch. My father's shares in Union Oil Company of Canada, Ltd. had to be liquidated. ${ }^{6}$ P. S. Ross \& Sons were authorized to handle these financial transactions. ${ }^{7}$ The Dominion of Canada Income Tax Department reviewed his financial affairs for the last 10 years and assessed an additional $\$ 94.90$ for 1940 and $\$ 5,543.22$, including $\$ 617.43$ interest, for 1941. My father bought a tractor which he rented to the DBL and blocks of timber from which he resold the timber to DBL on a stumpage basis. The additional tax was for rental and timber-which he had not been paid by DBL. ${ }^{8}$ On June 15, he received permission to meet with the tax people and with Mr. Wray of the Custodian, in Vancouver. On Sunday, he visited his mother's grave and the Milligans who were renting our Vancouver home.

The decision was made to offer the assets of DBL for sale by tender. In order to get the best offer P. S. Ross \& Sons hired Eustace Smith, a well-known timber cruiser, to examine the timber holdings, ${ }^{9}$ and Universal Appraisal Co. Ltd. to evaluate the equipment. ${ }^{10}$ Together they came up with a total estimate of $\$ 80,000$ for the timber and equipment. In August 1943, advertisements were placed in Vancouver and Vancouver Island newspapers, calling for tenders for the assets of the DBL in Fanny Bay, BC. Eight parcels designated A through H were listed and described. Five companies submitted bids by the August 31 deadline. H. R. MacMillan Export Co. Ltd. offered \$40,00o for the timber lands and camp buildings. The parcels included the log dump, booming ground foreshore leases, and the right-of-way from timber to dump with steel (tracks) removed. The price, which was above the value estimated by Mr. Eustace Smith, was acceptable; but many legal details had to be worked out with the bidder, lease hold-
3 G. W. McPherson (Letter with Authorization to C. M. Stewart, May 22, 1942); Notice appointing P. S. Ross \& Sons Inspectors, March 20, 1942.

4 D. D. Rosenberry (Letter to DBL Co., August 28, 1942).

5 G. W. McPherson (Letter to F. G. Shears, January 13, 1943); E. L. Robson (Letter to Mr. F. Field, P. S. Ross \& Son's Chartered Accountant, June 16, 1943); P. S. Ross \& Sons (Letter to F. G. Shears, June 21, 1943); F. G. Shears (Letter to G W. McPherson, July 12, 1943).

6 Unknown author. (Letter to Custodian, May 1, 1942).

7 C. J. Hadden, District Forester (Letter to P. S. Ross \& Sons, February 27, 1943).

8 C. M. Stewart (Letter to F. G. Shears, August 10, 1944).

9 Eustace Smith (Letters and Reports to P. S. Ross \& Sons, August 16, 1943 and September 9, 1943).

10 G. W. E. Skelding (Letter to Mr. Wray, August 11, 1943) 
11 F. G. Shears (Letter to E. Kagetsu, June 27, 1947).

12 Vancouver Equipment Corporation Ltd. (Letter to F. Field, November 27, 1947).

13 C. M. Stewart (Letter to Custodian, October 31, 1944)

14 P. S. Ross \& Sons (Letter to C. M. Stewart, March 21, 1945). Superseded by Letter to Eikichi Kagetsu, November 10, 1947.

15 C. M. Stewart (Letter to Custodian, December 11, 1941); G. W. McPherson (Letter to Deep Bay Logging Company, May 16, 1944). ers, and others before the sale could be finalized. Four other bids for the parcels in the bid package were not acceptable. On October 28, 1943, my father was notified of the offers. He accepted H. R. MacMillan's offer for the timberland.

There was confusion regarding the sale of the equipment due to poor communications and the Custodian pursued the sale of equipment separately. The Custodian chose the buyers carefully, but the estimates for the selling prices were too low. The saleable physical assets were finally completed in May $1947,{ }^{11}$ except for two steam yarders. ${ }^{12}$ The final approval on the sale of major assets was made by Dr. E. H. Coleman, Under Secretary of State and Deputy Custodian.

The Custodian bought $\$ 25,000$ of Victory Bonds using some of the proceeds from the sale of assets. The Custodian was informed that my father had no objections even though they would aid the fight against Japan. ${ }^{13}$ The Secretary of State ordered that all costs, charges, and expenses associated with the administration of my father's assets, including the original inspection, supervision, and winding-up of the business be charged to the assets or, in other words, paid by my father.

P. S. Ross \& Sons reported that the total realization from the assets of DBL as of June 30,1948 , was $\$ 86,467$. Out of this, $\$ 33,632$ was disbursed principally for accounts payable, watchman's wages, incidental expenses, and costs associated with the sale of the assets. My father was paid $\$ 9$, 000 for equipment and $\$ 14,000$ for timber blocks he owned in DBL, together with $\$ 10$, ooo owed for rental of equipment and for timber cut removed from his properties. ${ }^{14}$ The ownership of shares of DBL was changed to enable the Custodian to officially liquidate the company. ${ }^{15} \mathrm{~A}$ similar procedure was followed to liquidate Kagetsu and Company Ltd. My father's personal assets, including the MacKenzie Street house, motor vehicles, property in North Vancouver and others, were sold by the Custodian. The Custodian tried to void my father's rental agreement with our neighbour, the Milligans, for our home on 37th Street in order to sell it. The Milligans living in our home refused to move, and my father was able to go to Vancouver and have the things my family wanted to keep sent to Toronto.

\section{Ocean Timber Co. Ltd.}

In 1937, Mitsui formed a partnership with my father and established the Ocean Timber Company. It was agreed that any losses by my father would not exceed $\$ 25,000.00$, which was the amount of capital he put in. 
They intended to operate in a big way, and planned at a later date to acquire an adjoining block of timber known as Block 195, owned by the E\&N Railway. In May 1937, when my father notified the Mitsui manager that another company wanted to buy Block 195, they concurred that my father should purchase it in his own name before it was taken by the other company. My father secured a loan from the Yokohama Species Bank in Seattle for Block 195. The Seattle Office apparently never did get approval for this transaction from their head office, and my father was stuck with the property and had to keep making payments, including $\$ 5,000$ per year interest and taxes.

Ocean Timber's right-of-way was acquired from the Victoria Lumber \& Manufacturing Co. Ltd., and as part of the negotiations, Kagetsu gave this company the free right to use his own railway up north at the DBL operations. If it were not for the partnership with Mitsui, my father would have received $\$ 6,000$ per year for this right-of-way. My father was also stuck with the house on MacKenzie Street he purchased for use by Mitsui's manager. That my father had a legal right in regard to the monies expended on this project was considered debatable by the lawyers, but there was no question that the Mitsui people were under moral obligation to reimburse him. My father considered taking legal action. Mitsui was advised that their court costs would be at least $\$ 10,000$ and agreed on a $\$ 9,000$ settlement. ${ }^{16}$

With respect to Block 195, the Assistant Timber Controller tried to get the property into operation due to a shortage of logs. ${ }^{17} \mathrm{My}$ father received two bids that were not acceptable. The estimates of the amount of timber on the property was problematic. ${ }^{18}$ The Custodian took the matter into his own hands and in April 1943, advertised Block 195 for sale by tender. The H. R. MacMillan Export Co. Ltd. submitted the highest bid and was awarded the sale of Block 195. ${ }^{19}$ The price was below the $\$ 95,000$ paid by my father despite the higher price of timber. Settling the debt with the Yokohama Species Bank in Seattle by the Custodian was an international affair. ${ }^{20}$

\section{Bird Commission}

The Cooperative Committee on Japanese Canadians (CCJC) was organized in 1943 to help the Japanese Canadians. This group of Caucasians addressed the issue of getting compensation for the property losses suffered by Japanese Canadians. They requested the government "establish a claims commission to restore property where possible, to order restitution for losses where property
16 C. M. Stewart (Letter to G. W. McPherson, Custodian, [ca. 1942]).

17 D. D. Rosenberry (Letter to F. G. Shears, February 19, 1943).

18 C. M. Stewart (Letter to F. G. Shears, March 3, 1943).

19 F. G. Shears (Letter to P. S. Ross \& Sons, June 1, 1943).

20 D. J. Sinclair, Assistant Deputy Custodian (Letter to F. G. Shears, October 16, 1950). 
21 Fowke, 1951, pp. 27-28.

22 The New Canadian, November 15, 1946.

23 Fowke, p. 27 cannot be restored, and to grant compensation for net-loss in income as a result of evacuation. They found that the Secretary of State was responsible for dealing with the property losses. A legal committee under Mr. Andrew Brewin drafted terms for a commission, based partly on the "Evacuation Claims Committee" established in the United States previously to compensate Japanese Americans for losses incurred. ${ }^{21}$

The Japanese Canadian Committee for Democracy (JCCD) worked with the CCJC, to conduct a survey to determine the extent of property losses. ${ }^{22}$ The Toronto survey was completed in early 1947 and showed that properties owned by 200 claimants and valued at close to $\$ 1,500,000$, were sold for one quarter of their estimated value. No action was taken by the government until Angus MacInnis, CCF MP, raised the question in the House of Commons at the request of the CCJC. A commission was finally set up on July 18, 1947 and Mr. Justice Henry Irvine Bird of British Columbia was appointed as commissioner. ${ }^{23}$

The original terms of reference were too restricted and, through the efforts of Mr. Brewin, the government changed the terms of reference to "prove that property was sold at less than fair market value." The committee considered this change inadequate, but decided to accept the terms because they believed the government would not concede further changes. Mr. Brewin commented:

The commission is unique in the industry of Canadian jurisprudence.... Never before, however, has it been necessary to inquire into the value of many different source of properties lost to a large group of Canadian residents scattered all over the whole of Canada.

The CCJC reorganized to a smaller group, including Roger Obata, George Tanaka, and Kinzie Tanaka, which formed a legal committee to handle the claims. The CCJC, working with the Japanese Canadian Citizens Association (JCCA), arranged for legal representatives to handle the claims cooperatively. It was agreed that all claimants should be asked to pay one percent of the value of their claims into the pool to cover legal expenses. Later, an additional one percent was added. A "Loss Claim Form" was developed by the legal committee and distributed to all claimants by the JCCA. Mr. Brewin arranged for counsels to represent the claimants in every province. Over 1300 claims, amounting to over four million dollars, were prepared for filing by early 1948 with the aid of the JCCA officers across the country. General evidence was then presented to Commissioner Bird in the spring of 1949.

My father handled his claims through his own lawyers. Soon after the Japanese Property Claims Commission (generally referred to as the "Bird 
Commission") was established, he engaged Mr. Brewin to prepare the claims in Toronto, and Mr. Norris to prepare and present the evidence before Justice Bird in Vancouver. Since my father essentially had no records, the lawyers made many phone calls, wrote many letters, and made many personal contacts between October 1947 and November 1948 to gather information for the hearing before Justice Bird. Experts in various fields were engaged to help with the research, to conduct studies, and to appear as witnesses during the hearing.

My father's claim was filed on November 15, 1947, by Mr. Brewin. Since the terms of reference referred to "persons of Japanese ancestry," Mr. Norris had to get confirmation from Justice Bird that "corporations" were also included. The combined claim for the DBL and Kagetsu Co. was filed on January 6, 1948. A number of amendments to the original claim were filed as new information showed that the claim should be increased.

The hearing before Justice Bird began on November 8, 1948, in Vancouver. G. W. McPherson appeared for the Dominion government and Messrs. T. G. Norris, F. A. Brewin and A. Baldwin appeared for the claimant. During the preliminary discussion, Mr. Norris reviewed the claims as submitted on November 3, 1948. Block 195, timberland in the Cowichan Lake District, that my father purchased for the Ocean Timber joint venture, valued at $\$ 275,000$, was sold by the Custodian for $\$ 93,000$. Nine parcels of timberland at Fanny Bay in the Newcastle District, valued at $\$ 142,781$, were sold for $\$ 40,000$. The railroad, locomotive, logging railway cars, and other related equipment valued at \$22,925 sold for $\$ 13,000$. Wire rope, blocks, tools, etc., valued at $\$ 15,591.80$, were sold for \$7,104.53. The house in Vancouver, purchased for the Mitsui manager, a 1942 Pontiac sedan, and certain wire rope and boom chains, constituted a total loss of $\$ 2,393.75$. The total claim for real and personal property was $\$ 328,116.02$. When my father was called to the stand, he informed Justice Bird that the Canadian government had invited him to attend the unveiling of the Vimy Memorial, and that he was received by the King and Queen. My father wanted Justice Bird to know that he was a loyal Canadian.

Justice Bird's objective was to determine the fair market value of the property at the time it was sold by the Custodian. The major part of the claim revolved around the stands of timber. The quantities of the various types of trees on the property usually determined by cruisers and the price of different types and different grades of logs were key factors. Also, the market value was influenced by logging costs associated with the topography of the land, accessibility to water, and the distance and conditions for towing the booms of logs to market. A minor part of the claim addressed the value of equipment. The claimant presented ten witnesses in addition to my father, my brother, Hajime, and my 
father's bookkeeper, Henry Arikado. The government had five witnesses who set the market price the Custodian used as a guide when accepting bids.

The hearing concluded after ten days on November 25, 1948, during which 1,200 pages of evidence and 200 pages of arguments supported by 64 exhibits were presented. Commissioner Bird issued a 16-page report on Case 1388 on March 10, 1950. He awarded \$51,570.00. Later, $\$ 483.75$ was awarded for the house and car. On April 6, 1950, Commissioner Bird issued his report to the Governor General in Council. During the hearings for the 2,420 claims, 25,046 pages of evidence were given and 8,966 exhibits were filed. It was agreed to adopt a formula by which, on the general evidence already presented, the commissioner would recommend a general percentage allowance for each category of claim, with the provision that evidence could be presented in special cases to secure a higher award. Payment of the awards totaled $\$ 1,222,929 .{ }^{24}$

\section{Attempts to Have the Case Reconsidered}

Mr. Norris sent Commissioner Bird a five page memorandum on June 23, 1950, in which he enumerated "possible oversight of certain important matters of fact which virtually affect the result." He showed that when the facts are taken into account, the award for my father should have been $\$ 130,750$. On May 5 , 1952, a "Memorandum of Argument for Reconsideration of Award as to Compensation and Expenses" was submitted to Commissioner Bird. The June 23, 1950, memorandum was enlarged to over 40 pages and presented more details and new data from the government scaling records of November, 1951, that showed that $70 \%$ to $100 \%$ more timber had been taken off the property than allowed by Commissioner Bird. The revised claim based on this reevaluation totaled $\$ 365,555$. On February 12, 1954, my father, Hajime, Mr. MacInnis (MP) and John Osborne, a lawyer from Norris's office, met the Secretary of State, the Under Secretary of State and Mr. Wright of the Custodian's office in Ottawa to request that the awards and compensation of costs be reconsidered. There was no time to develop a full argument on the merits of the case or to review in detail the grounds for holding that the Commissioner had erred. They were able to draw particular attention to the glaring discrepancy between the volume of timber accepted by the Commissioner and the actual volume disclosed by cuttings subsequent to the Hearing. Mr. MacInnis expressed the view that the case ought to be reconsidered on grounds of public policy and 
Hajime Kagetsu pointed out that the award had never been accepted, and that the case should be regarded as still open for further study.

The Honourable John Pickersgill told them that he was not prepared to consider reexamination of this particular case but that, if they wished, he would speak to his colleagues about the possibility of reopening all of the Japanese cases. He said that he would submit the question to the Cabinet, but emphasized that he was not saying he would advocate it. He indicated rather clearly that there was little likelihood of Cabinet consenting to reopen all of the Japanese cases. $^{25}$

My father and Hajime believed that lobbying the government would provide a favourable outcome. Hajime immediately wrote a letter, in my father's name, to the National President of the JCCA, Mr. H.R. Okuda, requesting that the National JCCA make every effort on behalf of all evacuees to arouse the interest of as many groups as possible, and to make representations to $\mathrm{Mr}$. Pickersgill for a re-examination of evacuation losses. ${ }^{26}$

My father was quoted as saying: ${ }^{27}$

Should the Cabinet, of good mind and heart, approve of a general review of the losses suffered by the Japanese Canadians during the war and a favourable outcome result therefrom, a substantial amount of retribution may be forthcoming. The question, however, is whether a general reconsideration will be approved or not. In the interests of all Japanese Canadians concerned, it is desired that the JCCA and other organizations concerned with the welfare of JC's initiate action to arouse the interest of the general public in the matter. To put it literally, a spark has been lighted: let's try to fan it into a flame.

The Property Claimants Committee in Toronto also wrote to the National JCCA for their support in bringing this matter to claimants residing outside of Toronto, and for the National JCCA to submit a petition to the Secretary of State. There were meetings and exchanges of letters among the groups involved. The JCCA accepted Justice Bird's award on the recommendation of the CCJC and were unwilling to reverse that stand.

My brother, Hajime, prepared a one-page fact sheet, titled "Bird Commission Has Erred," in which he briefly described an example of an erroneous evaluation cited in the BC government records which showed the existence of a particular timber property with twice the volume of timber than the amount Commissioner Bird allowed. Over one hundred copies of this fact
25 John Osborne (Letter to T. G. Norris, Q.C., February 15, 1954).

26 H. Kagetsu (Letter to H. R. Okuda, February 13, 1950).

27 The New Canadian, February 17, 1954. 
28 Evacuation Losses Compensation Committee, Fact sheet to MP's, March 15, 1950.

29 John Pickersgill (Letter to H. Kagetsu, March 4, 1954); J. S. Gross, Secretary to the Prime Minister (Letter to $\mathrm{H}$. Kagetsu, March 30, 1954).

30 Angus Maclnnis (Letter to H. R. Okuda, March 29, 1954).

31 Canada. Parliament. House of Commons. Debates. (Hansard). 22nd Parliament, 1st Session. Official Reports. Volume VI, 1953-54, pp. 6094-98. sheet were sent out by the Evacuation Losses Compensation Committee to members of Parliament and the Cabinet. ${ }^{28}$

John G. Diefenbaker, then Conservative Leader of the Opposition, requested additional information and stated that he would bring the question of compensation loss to the appropriate committee in the House of Commons. Angus MacInnis, CCF MP, was also given details of my father's case. Responses to letters to Louis St. Laurent, the Prime Minister, and John Pickersgill, the Secretary of State, stated that the government was not willing to reopen the cases and that the government had discharged its obligations by carrying out the recommendations of Justice Bird. ${ }^{29}$ The matter came to a close after Angus MacInnis determined that the government had no intention to reopen any Japanese property case. ${ }^{30}$ MacInnis had an opportunity to address my father's case in a detailed speech in the House of Commons ${ }^{31}$ (see Appendix IV) while my father was seated in the gallery.

My father had no choice but to sign under protest the release that freed the government from any further claims and accept Justice Bird's settlement to avoid forfeiting the award. 
TREE TRUNK - MY PILLOW I KAGETSU

186 
CHAPTER 19

\section{Starting a New Life in the East}

\section{Struggling Through the Early Years in Toronto}

Department of Labour, 1944, p 13: Adachi, 1958, pp. 27-28.

2 Fowke, 1951, pp. 4-5. 
Sachiko and Akira arrived in Toronto in August 1943. My mother, Akiko, and I left a month later. The train trip took three days and two nights. We saw the majestic Rockies close up. In contrast, the prairies were so flat with wheat fields as far as you could see. When we reached Ontario, mother treated us to a meal in the dining car. Our first home in Toronto was in a rooming house at 17 Harbord Street, adjacent to the University of Toronto campus. We had two bedrooms: a small one on the second floor and a large one on the third floor. There was no kitchen. Meals were prepared using a hot plate with two elements. Okazu (side dish) such as fried baloney was prepared on the second element. As there were no TV dinners in those days, we often ate prepared food such as meat pies etc. On Sundays, my mother took us to a local restaurant for a hot meal.

Besides Akiko, Sachiko, Akira, and myself, my mother had to look after a sixth person. Dad told his friend that mom would look after his daughter in Toronto while she attended the University of Toronto. She roomed with us and had to suffer the inconveniences we had to go through. My mother made friends with Mrs. Obata, whose son, Roger Obata, had attended UBC with my sister, Kimiyo. Many Sundays, Mrs. Obata invited the five of us to her home for dinner. Another couple, Mr. and Mrs. Ozawa, and their two boys also lived in the same spacious house. Chiyo Ozawa was Roger's cousin. We will never forget the delicious meals we had with the Obatas and Ozawas and their kindness.

Roger Obata recalled: ${ }^{3}$

Since our mothers enjoyed playing bridge, this brought them together in a friendly way and I think it was really good for both of them. It was unusual for our mothers to be playing bridge as there were very few Isseis, either men or women who played bridge at that time.

Barney Ozawa, who was about a year older than me, became my best friend. On weekends, he took me to a movie, visited a museum, and did other interesting and enjoyable activities. During the winter, we would go skating outdoors at Varsity Stadium. There was a live band that played music for the skaters. One day while skating, I heard someone call out my Japanese name, "Tadashi," which I did not use in Toronto. The caller was a classmate of mine from Kerrisdale Public School. He was one of the boys who had put his arms around me when I returned to school after Pearl Harbor. He invited me to his home for dinner. It was a pleasant reunion. Unfortunately, he moved away soon after and I lost track of him.
3 Roger Obata (Recollections, September 4, 2000). 
My two youngest sisters, Akiko and Sachiko, who had their education cut short by the "evacuation," had no training or skills, and therefore had to work in a factory to help support the family. Akiko adopted the name Donna, Sachiko the name Lynn, and I reverted to Jack, the name the nurses called me when I was born. Donna and Lynn's first job was on the assembly line at the Imperial Tobacco Company. My sisters were good workers and soon got the choice job of placing excise stamps on the packages. They earned $\$ 13.25$ or $\$ 13.50$ a week. They gave all their pay to my mother to help cover our living expenses. The other siblings contributed what they could. My father did not send money to my mother to help keep the family housed and fed. Kimiyo brought piecework for my mother, who sewed beads and sequins on sweaters. I did a few myself. I wondered what some fashionable lady would think if they knew that their sweater had been decorated by a young Nisei boy!

\section{Later Years In Toronto}

In the spring of 1944, my mother decided that we needed to move into a house. She wrote to my father and he sent the money required for the down payment. Japanese Canadians were not allowed to own property in Toronto at that time. Miss Bird, a United Church of Canada missionary who worked among the Japanese Canadians, signed the papers for us. The house at 33 Howard Street was one of a block of row houses. The third floor was occupied by a widow and her son, and provided some income. The second floor had three bedrooms and the bathroom. The ground floor had a living room, dining room, and kitchen which had an ice box. There was a coal-burning furnace in the basement and a large coal bin.

In the meantime, family finances allowed my sisters to quit their factory jobs. Akiko attended the Pittman School where she learned shorthand, typing, and bookkeeping. She got a job as a stenographer for a company that made piston rings. A couple of years later she went to work for the United Welfare Chest, Welfare Council Section. Sachiko also attended Pittman School for a short time and took typing and bookkeeping. Sachiko got part time jobs that enabled her to resume piano lessons from Lily Washimoto, a noted soprano. She practiced for hours on end. Some of the pieces she played were Moonlight Sonata by Beethoven, Claire de Lune by Debussy, and a number of pieces by Chopin, including Fantasie Impromptu, Polonaise, and Grand Valse in E Flat Opus 18. Probably because of this exposure, my favourite type of music was 
classical piano pieces. Sachiko also gave me piano lessons. With my teacher always present, I had to practice diligently.

Miss Bird played a big part in making the life of the Niseis in Toronto more pleasant and easier. She formed a Nisei Young Peoples Group at the Metropolitan United Church - the largest United Church in Canada-and arranged for them to use the facilities. They formed a badminton club and held an annual Christmas Dance at the facility. Rev. Findlay of the Carleton United Church spoke out for the Japanese. A member of the Royal Canadian Mounted Police was present during the service to monitor what he said.

Akira enrolled in Central Technical High School as soon as he arrived in Toronto and continued his studies there through all the moves the family made. I started grade 7 at Huron Street Public School and transferred to Rose Avenue Public School when we moved to Howard Street. The neighbors offered me a variety of odd jobs. A widow had me wash her kitchen floor on a regular basis. She showed me how to clean toilets, a job I did not particularly like. Beginning in 1945, I had various summer jobs including delivering groceries and making awnings. In September 1945, I decided to attend Central Technical School mainly because my brother was going there. We both took the matriculation course that included grade 13-it prepared a student for university.

In September 1945, my father left Minto and came to Toronto. Two years later, he bought a bigger house at 8 Mountview Avenue, across the street from High Park in the western part of the city. It was located on a rather steep hill. There were steps from the sidewalk to the house level and more steps to the front porch. The driveway was steep. The living room was expanded. A dining room and kitchen occupied the first floor. There were four bedrooms upstairs and a bathroom on the upper floor. It was heated by an oil furnace.

In July 1948, I attended a chess tournament in Hollywood, California. A week later, on the morning of July 26th, I met my parents and Akira in New York City. We went sightseeing for three days and then we took the train to Washington, DC to do more sightseeing. My father visited the Tairiku Trading Company in New York City on business. In 1948, Akira and I bought our first car-a used Pontiac sedan - from a friend of the family. Our next door neighbour, Mr. Arthur, taught us how to drive. The family helped to pay for expenses related to owning and running the car.

In December 1950, Takako came home from Japan. The next year, she was diagnosed with tuberculosis and entered Queen Mary Hospital at Weston. Most Friday evenings, my mother accompanied by Akira or me, visited and took her Japanese food. By this time, effective medication had been developed to treat TB and Takako was cured and discharged after 18 months. The Japanese 
consulate in Toronto opened around 1953. Takako started to work for the Japanese consulate in Toronto the following year. Consul Kenzo Yoshida had his own secretary, but Takako helped him to write difficult letters and speeches.

The Nisei Women's Club was formed in 1954 with the encouragement of Mrs. Hide (Hyodo) Shimizu. Mrs. Hajime (Vi) Kagetsu was its first President. They raised money for worthwhile projects and had regular meetings. In March 1959, Kimiyo Takahashi and Hide Shimizu gave an informative address on Japan. ${ }^{4}$ At various meetings, my mother taught them how to make a yukata, how to perform the tea ceremony, and how to dress in a kimono properly. ${ }^{5}$

\section{Family Grows}

My oldest brother, Hajime, was working for the Marathon Paper Company near Fort William in their Forestry Department. He was the first to get married. On October 28, 1944, Hajime exchanged vows with Yoshiko Vi Momose, a girl whom he had met at UBC and dated in Vancouver. They lived in a small company town. Their children were named Stanley and Laurie. My father's savings were running low and he had not received any funds for the sale of his assets from the Custodian. He requested $\$ 2,000$ so that he could attend Hajime's wedding in Toronto. While in the East, he went to Montreal and Hamilton to visit friends. He returned to Minto in December.

My oldest living sister, Kimiyo, got married in 1946 to Yukio Takahashi, the brother of Hajime's friend, Saburo Takahashi, who studied engineering with him at UBC. In the following year they had a son, Bryan-my parents' first grandchild. Unfortunately, the marriage did not work out and Kimiyo and the baby returned to live at 8 Mountview. In a way this turned out well because she could keep an eye on our parents who were aging and the baby brought new life to the household. My father encouraged her to attend church.

The Young Peoples' Group at the Metropolitan Church sold tickets for their Christmas dance. Henry Ide, who was teaching in Pickering College in Newmarket, bought a ticket from Akiko and invited her to go with him. That was her first date with Henry, who was the first Japanese Canadian to teach in Toronto. They were married on August 27, 1949 and had three daughters, Donna, Carol, and Valerie. When the Niseis signed up for service as interpreters in the Canadian Army, a banquet was held for them in Toronto. Sachiko invited Mas Hyodo to the dance. They were married on July 7, 1951. They had a son, Franklin, and three daughters-Mary, Margaret, and Linda. Akira met 
Elsie Saito at the Young Peoples' Group at the Metropolitan Church. On October 10, 1953, Akira and Elsie were married. They had four children: Diana, Timothy, Catherine, and Nelson. Takako met C-J (Louis) Huang at a party the Tuckers had to celebrate his $\mathrm{PhD}$ graduation from the University of Toronto. They were married on August 6, 1955 and had three children, Helen, William, and Grace.

I met Kanaye Kay Tsuchida at a dance put on by the University of Toronto's Nisei Students Club. She was a teacher at Jesse Ketchum School in Toronto. We were married on July 20, 1957 after I completed the requirements for my $\mathrm{PhD}$ degree in chemical engineering. We had two children, Nolan and Naomi.

If you were counting, my parents had nineteen grandchildren. We celebrated our parents birthdays, Christmas, and New Years at "home." The house would be crowded and noisy, especially when the children were young. There was always lots of good food!

\section{Strive High}

My father was always encouraging his children to strive high. He said, "It doesn't matter what you do, but give it your best."

My sister Sachiko and her husband, Masao Hyodo, became serious Bridge competitors and earned the rank of "life master" awarded by the American Contract Bridge League (ACBL). They had to earn a certain number of master points and additional master points in certain designated tournaments in which the stronger players participated. Since top players did not usually play with their spouse, this was a noteworthy achievement and was written up in Bridge World, the publication of the ACBL. ${ }^{6}$

In high school and university, I played a lot of chess. A freelance writer described my chess activities in part as follows: ${ }^{7}$

The 23-year-old youth has beaten world Grandmasters like Russia's Alexander Kotov, America's Sam Reshevsky, and Holland's Dr. Max Euwe. $\ln$ the realm of sports, that would be the equivalent of a young ball player scoring home runs off Bob Lemon, Sal Maglie, and Robin Roberts. It's meeting and conquering the highest company in the field.

The grandmasters were playing simultaneous matches, but these victories are rather considerable since the quality of play is

6 The Bridge World, date unknown.

7 Nakamoto, 1954. 
excellent all-around. Kotov was playing 28 at the same time, lost 2. Reshevsky handled 38 at one time, lost 1 and Euwe took on 52 simultaneously, lost 3. In this kind of match, chessboards are set up around a room. The grandmaster goes from table to table, sizing up each situation quickly, playing immediately.

Jack started playing when he was 7 years old. In one game during his "formative" period, sister, Sachiko promptly beat him in 4 moves. "It was the first time I lost to a woman," declared Jack. "It wasn't the last either. I was beaten in California recently by Mrs. Mary Bain, one time U.S. women's chess champion. "Mrs. Bain was kind. She said she thought I should have at least tied her."

In high school, Jack represented Canada in U.S. Junior Chess Championships. In college, he was champion of University of Toronto's Hart House Chess Club.

After graduating from high school, I enrolled in Chemical Engineering at the University of Toronto. The yearbooks and newspapers indicated that Tadashi Kagetsu was awarded scholarships for being the top student in the first and third years of Engineering. ${ }^{8}$ When I got my PhD my father often mentioned the Nobel Prize as a worthwhile goal.

\section{Business Ventures in Toronto}

My father wanted to start a business in Toronto using some of the money from the sale of his assets by the Custodian and the award by the Bird Commission. In 1948, Mr. Sokichi Ito came from Montreal to help my father order goods from Japan. Samples of tablecloths, parasols, tea, and other goods were received. They visited wholesalers in Toronto, but these goods received a "mild reception." More merchandise arrived from Japan the next year, but the market was slow except for towels that sold well. My father wanted Hajime to help him in the business. Hajime and Vi weighed the security of a job with a big company and the living conditions in a small company town versus the uncertainties of a new business. They decided to move to Toronto to keep my father happy. When Hajime arrived in Toronto in July 1950, he found that the Japanese merchandise was not in demand.

8 Globe and Mail, May 30, 1951; May 1953.
He and my father decided to open a gift store specializing in Japanese goods. The family had a contest to come up with a name for the store. Hajime's entry, 
the Eglinwood Shop, based on the location of the store at the intersection of Eglinton and Oakwood, was selected. Kimiyo managed the store which had a large basement to store the large quantities of merchandise arriving from Japan. The apartment above the store was the source of some income.

From the start, Sachiko did the bookkeeping for the Eglinwood shop. When she got married in 1951, Takako took over the bookkeeping. The company could only afford to pay a nominal salary. Most of the year, the store wasn't very busy. Kimiyo supplemented her income by using her sewing skills to do alterations for her customers' clothes. Christmas was the busiest time of the year and family members helped to man the store. The sale of Japanese goods picked up then since many Japanese Canadians who lived throughout Toronto shopped at the store.

An import company, Pacific Trading Company, was formed to wholesale Japanese goods and was managed by my brother, Hajime. He worked hard at selling and by the end of the year, there was an improvement in sales. My mother spent months and months sewing hems on silk scarves. Also, on her trip to Japan in 1954, she visited a number of wholesalers and ordered fresh items for the business. While in Japan, former students whom she taught before her marriage held a party for her. Hajime rented a booth at the Canadian National Exhibition across from the grandstand. Family members helped to man the booth at night. We got an influx of customers after the grandstand show. Merchandise such as camera lighters, etc., were sold to reduce Pacific Trading's inventory.

In 1952, Kagetsu Company Limited, that included the Eglinwood Shop and Pacific Trading, was incorporated. The capital was put up by my father, but family members held varying quantities of shares. Hajime wrote a monthly business letter for the Tokyo Trade Association in Japan. In one article he discussed "Lower Canadian Tariffs and Japanese Products." Rather than increasing the quantities of the same type of merchandise, he stated that Japan must seriously consider improving the quality of products that have a higher price and have a strong marketing strategy. With higher-priced items, transportation costs become relatively less. ${ }^{9}$

My father decided to close Pacific Trading, which was not doing very well, and got into the dry cleaning business recommended by a friend. Neville Park Cleaners was purchased and incorporated in 1956. My father had limited funds left, so Hajime put his own savings into the business and was the majority shareholder. Kagetsu Company Limited also provided equity in this business. The assets included a dry cleaning plant with receiving depot and a second receiving depot in another building. It took a few years to get the business grow- 
ing. There were cash flow problems to take care of. Hajime's wife got a job and their son, Stan, worked at the cleaning plant ironing shirts during summer vacation. Nevertheless the business did a little better than break even and eventually he was driven out of business by stiff competition and by the growing popularity of "wash and wear" clothing. At the end when all debts including back-salaries were paid, my father's only remaining asset was the house on Mountview Ave. 
TREE TRUNK - MY PILLOW I KAGETSU

196 
CHAPTER 20

\title{
The Elder Statesman is Still Active
}

\author{
Judo
}

$M$

$\mathrm{y}$ father continued his interest and support of judo after he moved to Toronto. The following are a few examples of accomplishments by Niseis that he admired. In 1947, Frank Hatashita founded a dojo (place for judo training) in a Toronto garage using a home-made tatami. Of the eight original members of the dojo, three were his brothers, Oscar, Tom, and John. As the number of members grew, he moved to larger quarters. Eventually he ran or sponsored about 100 dojos in Ontario. ${ }^{1}$

There was a National Black Belt Judo Tournament in Hull, Quebec, organized in the winter of 1949 by Henri Gauthier, the Mayor of the City of Hull. My father attended as the official delegate of Canada Judo Yudanshakai (or, Black Belt Association). Mr. Bernard Gauthier, the President of the Canadian Judo Federation and the son of the Mayor, was present along with Mr. Shigetaka Sasaki, the "Father of Canadian Judo." Masao Takahashi beat a Mounted Policeman who was about a foot taller, and defeated John Hatashita in the finals to win the championship. Mas had a dojo in Ottawa where he went on to teach judo to Prime Minister Trudeau and his three sons. Later, Prime Minister Mulroney's three sons attended his dojo. Mas's wife, three sons and 


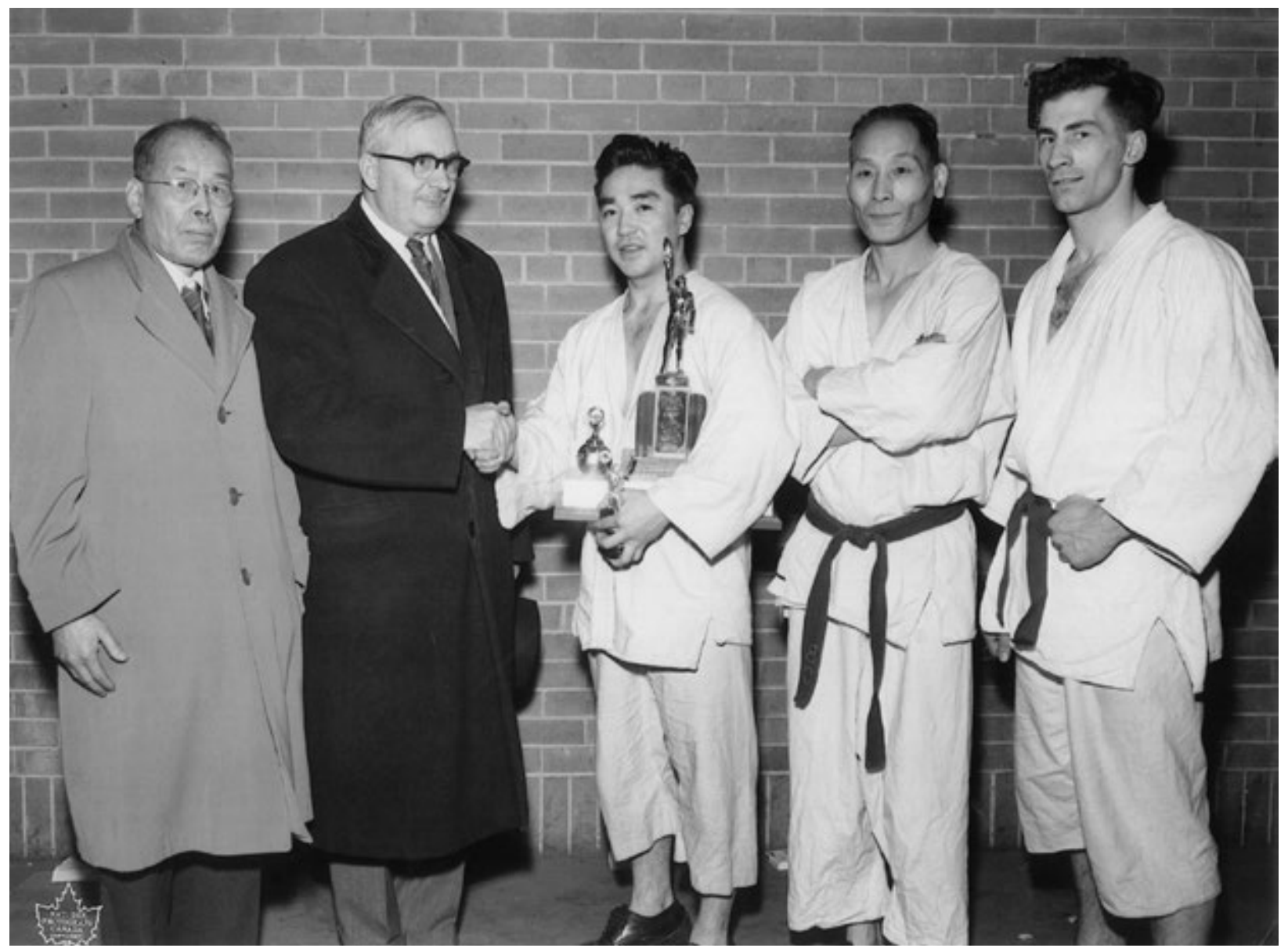

National Black Belt Judo Tournament

daughter earned their black belts and won numerous national titles and gold medals in international competition. ${ }^{2}$

in Hull, Quebec 1949. Left to right:

Eikichi Kagetsu, Henri Gauthier, Masao Takahashi, Shigetaka Sasaki, Bernard Gauthier.

2 Mas Takahashi (Letter to Jack Kagetsu, October 30, 2000); Leyshon, pp. 7578, 134-135. 


\section{Toronto Buddhist Church}

After coming out east, Rev. Tsuji attended the University of Toronto and subsequently organized a Buddhist Church in Toronto. The church was a house on Huron Street purchased in October 1947. The Tsujis lived on the second floor and the main floor was used for church services. ${ }^{3}$ Elders like my father (former President of the Hompa Bukkyo Kai in Vancouver) and Sukegoro Mori (former President of the Fairview Bukkyo Kai) served as advisors in the early days of the Toronto church. ${ }^{4}$

As membership and activities grew, a building committee chaired by Mr. Zentaro Shin was formed in 1950 to find larger accommodations. My father served on the building committee with others. Three years later, the new Central Executive Board decided to build a new church building and to purchase land on Bathurst Street. The first Buddhist temple to be built in Toronto cost $\$ 70,000$ and the architect's design won recognition. The only problem was that there was no space for parking. However, it was accessible for the older people who could travel there by street car. ${ }^{5}$

My father constantly preached that green vegetables were good for you with all its vitamins. My father grew variety of green vegetables in his backyard and made tsukemono, Japanese-style pickled vegetables, lightly salted and pressed. He brought a jar of tsukemono to a Church picnic. My father told Mrs. Tsuji that her husband should eat his tsukemono so they may have a son. The Tsuji's had only two girls at that time. My mother was embarrassed by this and told my father, "You shouldn't say things like that!"

Rev. Tsuji recalled: ${ }^{6}$

I often visited your home on Mountview Avenue to discuss Church matters with your dad and to get his guidance.... Your father had long experience in leading people and everybody trusted him.... He was a great leader and commanded great respect from everybody. He was a man of great vision and had a wide viewpoint. He was a tremendous person.

On August 6,1949, the Continental Family Cooperative was formed by the Toronto Buddhist Church to help its members get hold of Japanese groceries for purchase. My father was elected Chairman of the Board of Directors. Together with other Issei leaders, the co-op operation was organized. The coop store opened on Dundas St. West in 1950 and offered staples of Japanese 
cuisine. The profits were generally donated to the church treasury. The co-op did not last long and eventually became the Furuya Japanese Food Store. ${ }^{7}$ The Continental Family Cooperative Union presented my father with a certificate of appreciation dated October 1954 that reads:

For six years after the founding of this Union, you have served continuously as a director in the operation and development of this Union. In view of your great service and on the occasion of your retirement-we wish to present to you herewith a gift and an expression of our deepest appreciation.

My parents carried on many Buddhist traditions in their home. There was a butsudan, a small shrine, in my father's bedroom and my mother offered fresh rice and fruit in front of it daily for departed family members. On special dates we had family memorial services in the living room where a Buddhist priest presided over the ceremony. Although most of it was in Japanese, each child and grandchild paid his respects to the dead individually with a bow and incense offering. ${ }^{8}$

At the January 1958 Annual General meeting, Rev. Tsuji announced that he had accepted the appointment as Director of Buddhist Education in San Francisco, California. When my father visited Nishi Honganji, the head temple in Kyoto, the Head Bishop presented him with a scroll/wall hanging that displayed beautiful calligraphy, which read "Butsu Shin" or "Buddha's mind is great compassion." My father gave this scroll to Rev. Tsuji when he left for San Francisco. ${ }^{9}$

\section{Outstanding Japanese Canadians}

The Japanese language section of The New Canadian polled its readers in 1950 to select the "Japanese Canadian of the Half Century". The top five in order were Etsu Suzuki, Yasushi Yamazaki, Shinkichi Tamura, Eikichi Kagetsu, and Jiro Inouye. ${ }^{10}$ The article mentioned that my father was a successful lumberman on the BC coast before the "evacuation" who was also influential in Japanese welfare.
7 Watada, p. 301

8 Recollections by Mary Hyodo McCracken.

9 Rev. Tsuji (Interview, May 26, 1998).

10 The New Canadian, March 1, 1950, English and Japanese Sections. 


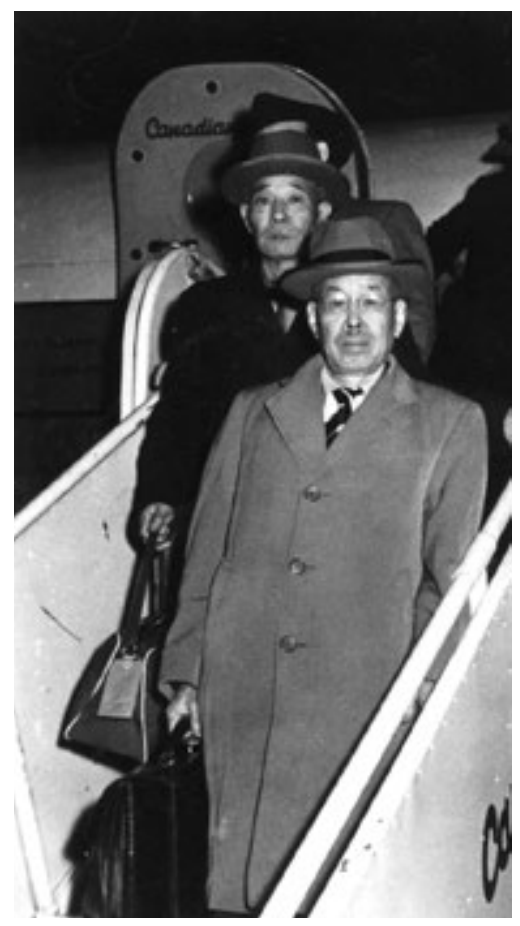

Eikichi Kagetsu and Mr. Maeda arrived at Haneda Airport (Tokyo) before the main 1955 Kotobuki Kai Tour Group.

11 Continental Times, January 1, 1976.

12 The New Canadian, February 2, 1955.

13 Nippon Times, February 12, 1955; Mainichi Shinbun, February 12, 1955.

14 Nippon Times, February 14, 1955.

15 Nippon Times, February 16, 1955.

16 The New Canadian, February 16 \& 26, 1955.

\section{Kotobuki-kai}

In Toronto there were over 350 Japanese Canadians over the age of 60 years. In 1950, my father organized the Kotobuki-kai to promote fellowship and recreation for the Japanese-Canadian senior citizens and served as President. "Kotobuki" literally means longevity. ${ }^{11}$ Every year, they held a New Year gathering in January and a picnic in High Park. After serving as Chairman of the Board of Directors for four years, my father resigned from the position. The Kotobuki-kai organized the Japanese Canadian Pioneers Japan Tour Group to celebrate the fifth anniversary of its founding. My father was the leader of the group. The objectives of this trip were simply to revisit relatives and friends, to go sightseeing, and to see with their own eyes the postwar reconstruction of Japan. For Isseis, there was a strong feeling of wanting to breathe the air of Japan one more time. A send-off party attended by nearly 300 well-wishers was held in Toronto for the 62 participants. ${ }^{12}$

My father and Mr. Maeda left for Japan on February 10 before the main group departed because the chartered plane could hold only 60 passengers. They flew to Haneda Airport in Tokyo on a Canadian Pacific Airlines (CPA) flight. ${ }^{13}$ While waiting for the tour group to arrive, my brother, Hiroshi, used his company car to drive my father to visit with his old friends Japanese Consul in Vancouver, Tatsuo Kawai, the first Japanese Minister to Canada, Iyemasa Tokugawa, and his colleague at Ocean Timber, Mr. Shimazaki. Mr. Kawai was instrumental in arranging a meeting with the Imperial Chamberlain, the Emperor's representative to the public. My father presented a gift to the Emperor from the tour group through the Chamberlain. He also spoke in detail with the Chamberlain about Canada and asked him to convey the information to the Emperor with copies of his book, Kanada to Nihonjin (Canada and the Japanese people).

The main group left Toronto to join the others in Vancouver. They left Vancouver on February 13 on the chartered CPA flight to Tokyo. ${ }^{14}$ The oldest returnee was 82-year-old Eiji Sasaki who left Hiroshima for Canada in 1905 and was returning for the first time after 50 years. ${ }^{15}$ Their arrival in Japan on February 15 was covered by the national media in Japan. The Kanada-kai, a society of former Japanese Canadians and diplomats to Canada, held a welcome banquet for the tour group. Mr. Iyemasa Tokugawa and former consul in Vancouver, Mr. Ko Ishii, were present to welcome the Issei. ${ }^{16}$

In the afternoon of the February 17, Eikichi Kagetsu, Tomojiro Kadonaga, and Naokichi Takimoto, representing the Japanese-Canadian tour group, 


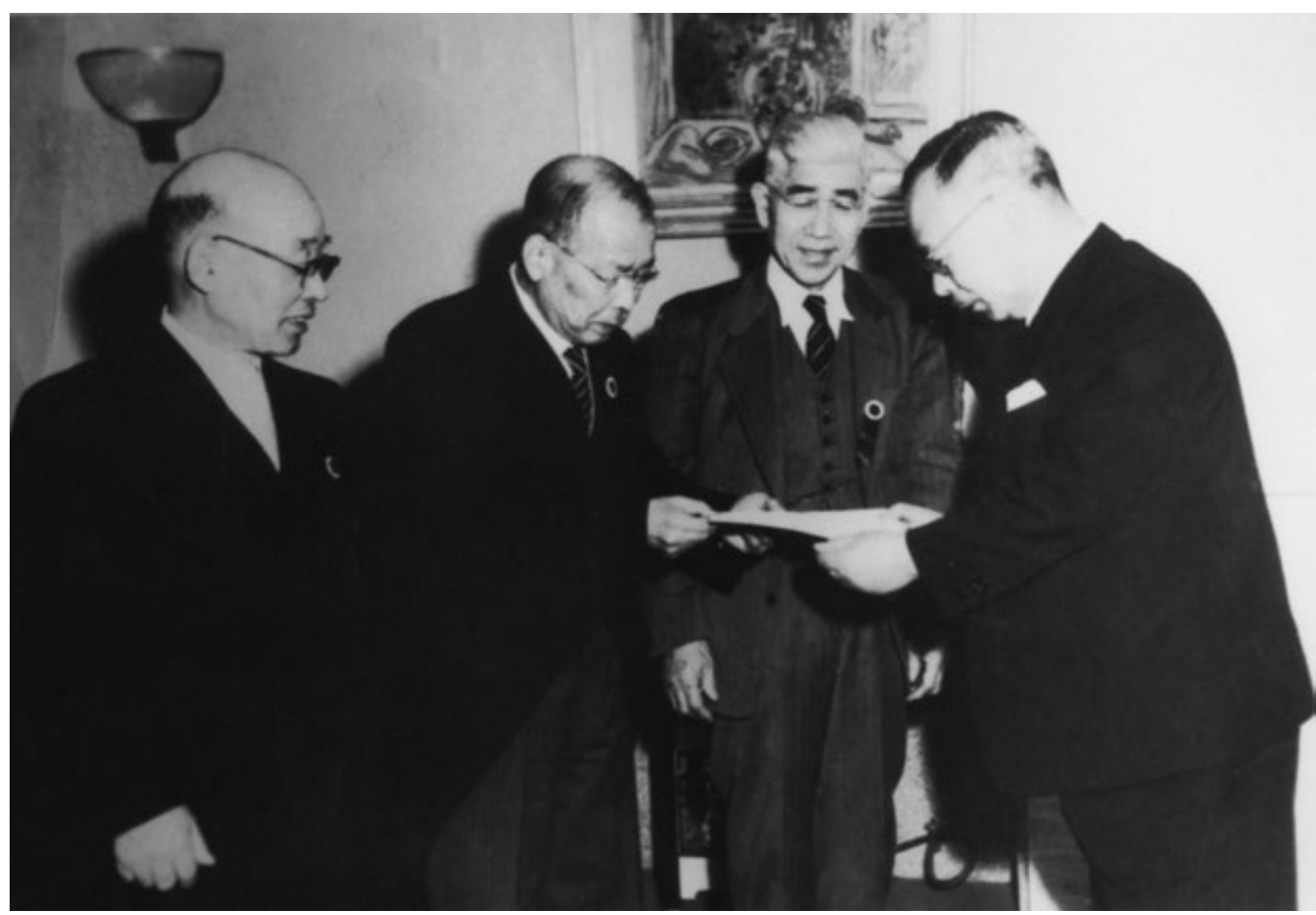

called on Tokyo Governor Seichiro Yasui and delivered the following message from Mayor Nathan Phillips, QC, of Toronto to the citizens of Tokyo. ${ }^{17}$

I understand that a representative group from the Japanese Canadian Elderly Association, are leaving Canada for Japan on February 13th for a sight-seeing tour, and it gives me much pleasure, on the occasion of their visit, to extend to you and the citizens of Tokyo, most cordial greetings and best wishes from the Corporation of the City of Toronto.

Chairman Eikichi Kagetsu, Tomojiro Kadonaga and Naokichi Takimoto presenting letter of greetings from Mayor of Toronto to the Governor of Tokyo.

17 Nathan Phillips, (Letter to Seichiro Yasui, Mayor of Tokyo, February 4, 1955). See also Mainichi Shinbun, February 18, 1955; The New Canadian, February $9 \& 26,1955$ 
I recall that the Crown Prince of your Country visited Toronto while en route to England to attend the Coronation of Her Majesty the Queen, at which time the City was privileged to accord His Highness a civic welcome.

I am sure that the group of Japanese Canadians will derive great benefit and much enjoyment from their visit to your Country.

Mayor (Nathan Phillips, Q.C.)

In response, the Governor of the City of Tokyo asked the group to convey his greetings to Mayor Phillips. ${ }^{18}$ When told that many of the Issei tourists were making the trip through the support of their children, Gov. Yasui was much impressed. ${ }^{19}$ My father commented to the Governor that it may be superficial, but Japan's recovery from war destruction seemed very rapid and that he was surprised at how well-dressed the people were. ${ }^{20}$

The first ten days were spent sightseeing in Tokyo, Nikko Shrine, Yokohama, Kamakura, Enoshima, Hakone, Atami, via Nagoya to Ise Shrine, Kyoto, Nara, and Osaka. In Kyoto, the group presented a donation to Nishi Honganji, the Head Temple for Buddhists in Canada. On February 27, the tour group disbanded in Osaka with the members going their separate ways to their home prefecture or other destinations of their choosing. ${ }^{21}$

After the tour group dispersed, my father visited Tamura Shokai and the Mayor of Osaka. Back in Tokyo, with help from Mr. Suzuki and Mr. Iwanaga, my father invited 26 old friends to dinner. My father visited Prime Minister Shigeru Yoshida, who had been Ambassador to Great Britain when he befriended my father in London during the Vimy pilgrimage in 1936. He was one of the key signers of the World War II Surrender Agreement in September 1945, and was the Prime Minister of Japan for two terms after World War II. He presented my father with calligraphy he wrote to commemorate the occasion. The calligraphy was a poem by Confucius written in Chinese from right to left horizontally: "Is it not a joy indeed to have a friend come from afar?" Then reading right to left vertically it gives the year as "1955," using the Chinese Sexagenary Cycle, "Showa," the Japanese emperor's era, "spring," Mr. Yoshida's nom-de-plume that stands for his initials and "written by." In those days, educated people were well-versed in Chinese classics.

As with the flight to Japan, the chartered plane could only hold 60 passengers, so my father left Tokyo ahead of the tour group. One of the media groups provided a photographer that accompanied the tour group while sightseeing. Some of the films were developed in Japan so that they would be ready when

21 The New Canadian, February 16, 1955. 
the tour group returned to Toronto. They got together and viewed the pictures before disbanding with wonderful memories.

\section{Other Activities}

My father was one of the founding members of the Toronto Japanese Garden Club. He was also an "Honorary Officer" of the Issei-bu (Issei Section) of the Toronto JCCA. He was in contact with compatriots from Wakayama Prefecture living in the United States. He was listed with his address and a brief biographical sketch in a directory of Wakayama Prefecture natives living abroad. ${ }^{22}$

Mr. Kazuo Ito, a Japanese American, wrote a book, A History of Japanese Immigrants in North America, a comprehensive history that was translated into English. Mr. Ito visited our home while he was in Toronto and wrote that my parents took excellent care of him. ${ }^{23} \mathrm{Mr}$. Iyemasa Tokugawa was the minister to Canada prior to World War II. After his return to Japan, he became President of the Japan-Canada Society, an organization whose aim was to promote better understanding and to foster goodwill between the two countries. In May 1962, he attended the completion ceremonies of the Nitobe Memorial Japanese Gardens at the University of British Columbia. Mr. Tokugawa raised 8 million yen in Japan to help complete the construction of this garden. ${ }^{24} \mathrm{He}$ stayed in Toronto for three days before leaving for Ottawa and Montreal. ${ }^{25} \mathrm{My}$ father held a little party for his old friend at our home.

\section{Saisei-Kai (Social Welfare Foundation) ${ }^{26}$}

My father had custody of Saisei-Kai funds after the Pearl Harbor attack and was able to protect this money from confiscation by the government. In an effort to put the funds to some use for the Japanese in Canada, a meeting was held in January 1955 in which Consul Kenzo Yoshida and Vice-Consul E. Uchida were invited to express their views. It was decided that the Foundation's administration should be revived and a meeting of community leaders be called to discuss the wisest possible use of the funds. ${ }^{27}$

Mr. Jenichi Iwashita devoted much time and effort on the paperwork required for the formation and incorporation of the Saisei-Kai. ${ }^{28}$ On June 19, the Saisei-Kai was officially established in Toronto with a current balance totaling
22 Hieda, 1965

23 Ito, 1973.

24 The New Canadian, April 25, 1962.

25 The New Canadian, May 5, 1962.

26 Wangenheim, 1963.

27 The New Canadian, January 22, 1956.

28 The New Canadian, March 3, 1960, Japanese Section. 


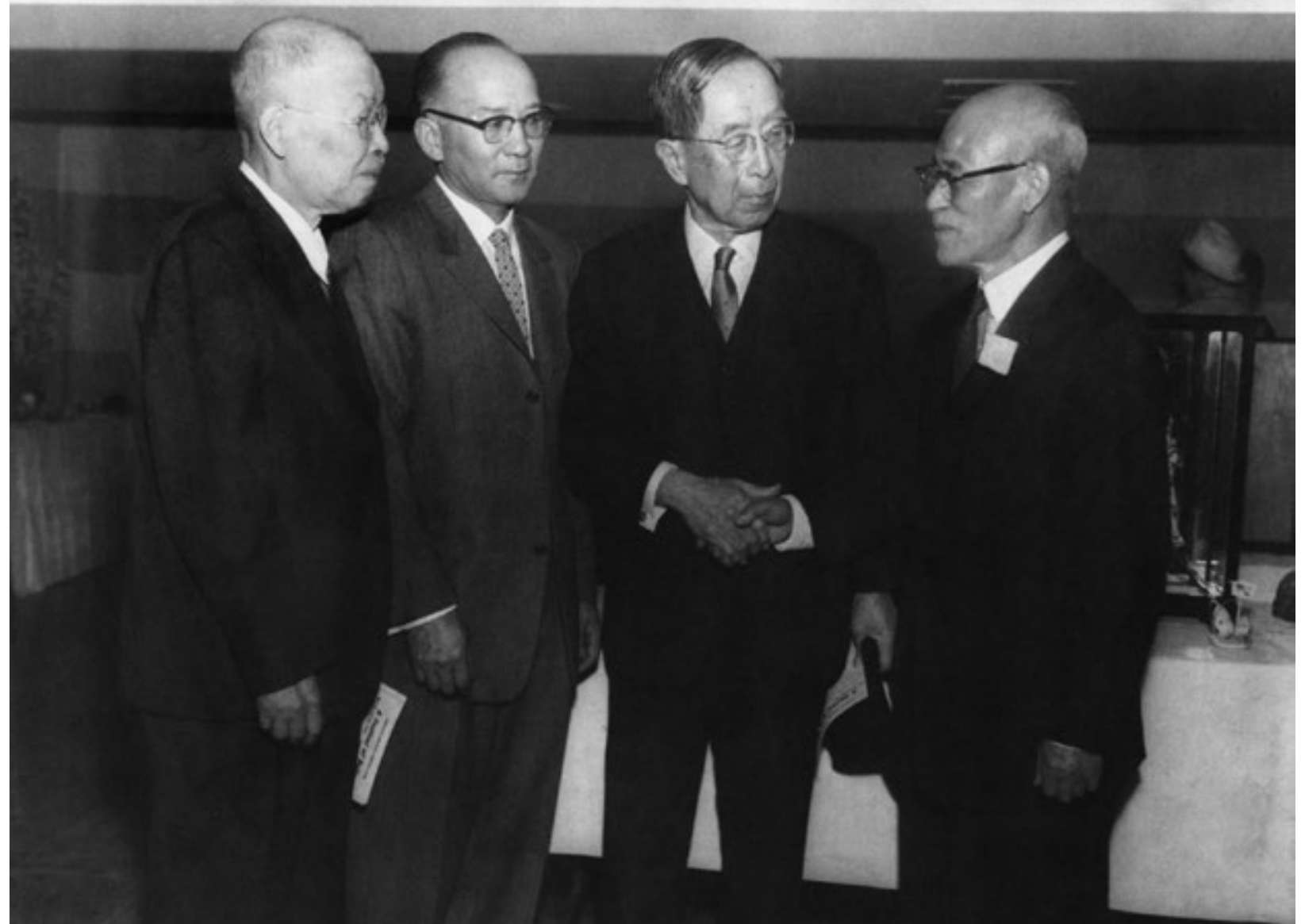

Iyemasa Tokugawa, the former Minister to Canada, visited Toronto in 1962. Left to right: Eikichi Kagetsu, Mamoru Nishi, Iyemasa Tokugawa, unidentified.

29 The New Canadian, June 23, 1956.
$\$ 12,035.68$. My father was elected President. The funds were to be expended for philanthropic, charitable, educational, and social projects or other projects of a useful nature, particularly, but not exclusively, among members of the Japanese-Canadian community.

The first 65 members were all Isseis. In the first year of operation, the organization planned to concentrate on developing a large membership and to solicit Nisei members. ${ }^{29}$ At a directors' meeting the following year, a Canada-wide 
membership drive was planned and letters were sent to various organizations and individuals who might be interested in joining. ${ }^{30}$

Mrs. Helen Tucker was in charge of organizing the so-called "East-West Cultural Mission" to Japan for the Canadian UNESCO (United Nations Education, Scientific and Cultural Organization) Committee. The mission's objective was to promote understanding and goodwill between Canadian and Japanese peoples through personal contact with Japanese people and their cultures and civilization. She informed the Japanese Consul, Mr. Endo, that they would be very happy to have a Japanese-Canadian member on the mission and requested his assistance.

At the General Meeting of the Saisei-Kai on March 28, 1958, "A resolution endorsing the project and pledging its support and cooperation" was passed, and a special committee including my father and six others was appointed to implement the resolution. ${ }^{31} \mathrm{Mr}$. Edward Ide, President of the National JCCA, Mrs. Kim Takahashi of Toronto, Mr. and Mrs. Shingo Murakami, and Miss Lily Murakami of Vancouver were selected to be on the special committee. During their one-month stay, 30 members of the mission met with various Japanese organizations such as the Society for International Cultural Relations, the International Association of Women, the Japan United Nations Association, and the Japan Canada Society. The high point of the mission was the presentation of UNESCO gift coupons to the International Peace Library in Hiroshima which replaced the university library destroyed by the first A-bomb. ${ }^{32}$

Over the years, the Saisei-Kai awarded scholarships to Japanese-Canadian university students, funds for studies of Japanese-Canadian history, aid to flood victims, aid to Nipponia Home, assistance for travel expenses to Japan for Japanese-Canadian representatives of UNESCO, and funds for other needs. In an interview for The New Canadian on the Saisei-Kai, Mr. Iwasaki, a noted Japanese-Canadian newspaper reporter, stated:

From its inception to this day, Mr. Kagetsu has borne the responsibility of being its President. "Mr. Iwashita does all the work, I'm just decoration" he modestly says, but Mr. Kagetsu has bold plans for Saisei-Kai's funds. "If we can maintain the funds for 211 years, at that time, it will be worth $\$ 40,096,000$. If you have $\$ 40,000,000$, the Japanese Canadians can build a bank ..." he says with a surprisingly straight face. It was amazing to realize that even with age a business man's thinking paints such huge strokes.

Mr. Kagetsu says "My main goal is to continue the policy of not touching the capital." The good news is that this year there are

30 The New Canadian, May 8, 1957.

31 The New Canadiann, May 7, 1958.

32 The New Canadian, June 7, 1958. 
69 new members of whom most are Niseis. It's good to have the young ones take over." Mr. Kagetsu quietly looks out the picture window. This is the pose of a pioneer of merit and fame. ${ }^{33}$

My brother, Hajime, succeeded my father as President of the Saisei-Kai. In a letter to select Nisei members in 1965, Hajime stated:

While the good founders of our society are still around, I believe the philosophy, creeds, and certain policies need specifying and a longrange master plan of Saisei Kai's future needs to be sketched out.

He enclosed nine cartoons that were prepared at his own expense to illustrate his concerns. He wanted to avoid excessive handouts at the time and to keep and grow the principal, so that money would be available for future worthwhile projects. He was worried about new members who had their own agenda and who were not particularly concerned about the future of the SaiseiKai. For the Saisei-Kai's 35th anniversary in 1969, he wrote an article describing his evaluation and concerns. ${ }^{34}$ 
TREE TRUNK - MY PILLOW I KAGETSU

208 


\section{CHAPTER 21}

\section{Lifés Sunset}

\section{Passing the Time}

1 Recollections by Mary Hyodo McCracken.

2 Tenkai, 1956 ur home at 8 Mountview was very close to Bloor Street and High Park. It was located on a steep hill and had a steep narrow driveway. In the basement-at the front part of the house-the foundations formed a little room that my father made into his "den." In another part of the basement, he covered a storage area wall with postcards showing Japanese ships.

My father put in a vegetable garden in the relatively small back yard. He obtained permission to use part of our neighbour's garden to grow vegetables and flowers. After my brother Hajime moved to Toronto in 1955, he built a greenhouse using one end of the garage and the space between the end of the garage and the fence. This enabled my father to get an earlier start on growing seedlings that he transplanted outside when the weather got warmer. He collected rainwater in a barrel and watered the garden by hand using this "good" water. ${ }^{1}$ He kept busy by tending his vegetable garden, growing flowers, and cutting the front lawn. He was happy when he could give vegetables and flowers to friends and neighbours. In 1955, on his return from the Kotobuki Kai trip to Japan, he brought back chrysanthemum cuttings from Vancouver. He planted them in wooden planters as he did in Vancouver and they "bloomed very nicely." He had a book on How to Cultivate Large Chrysanthemums. ${ }^{2} \mathrm{He}$ won several awards at the Toronto flower shows. He enjoyed growing chrysanthemums. 


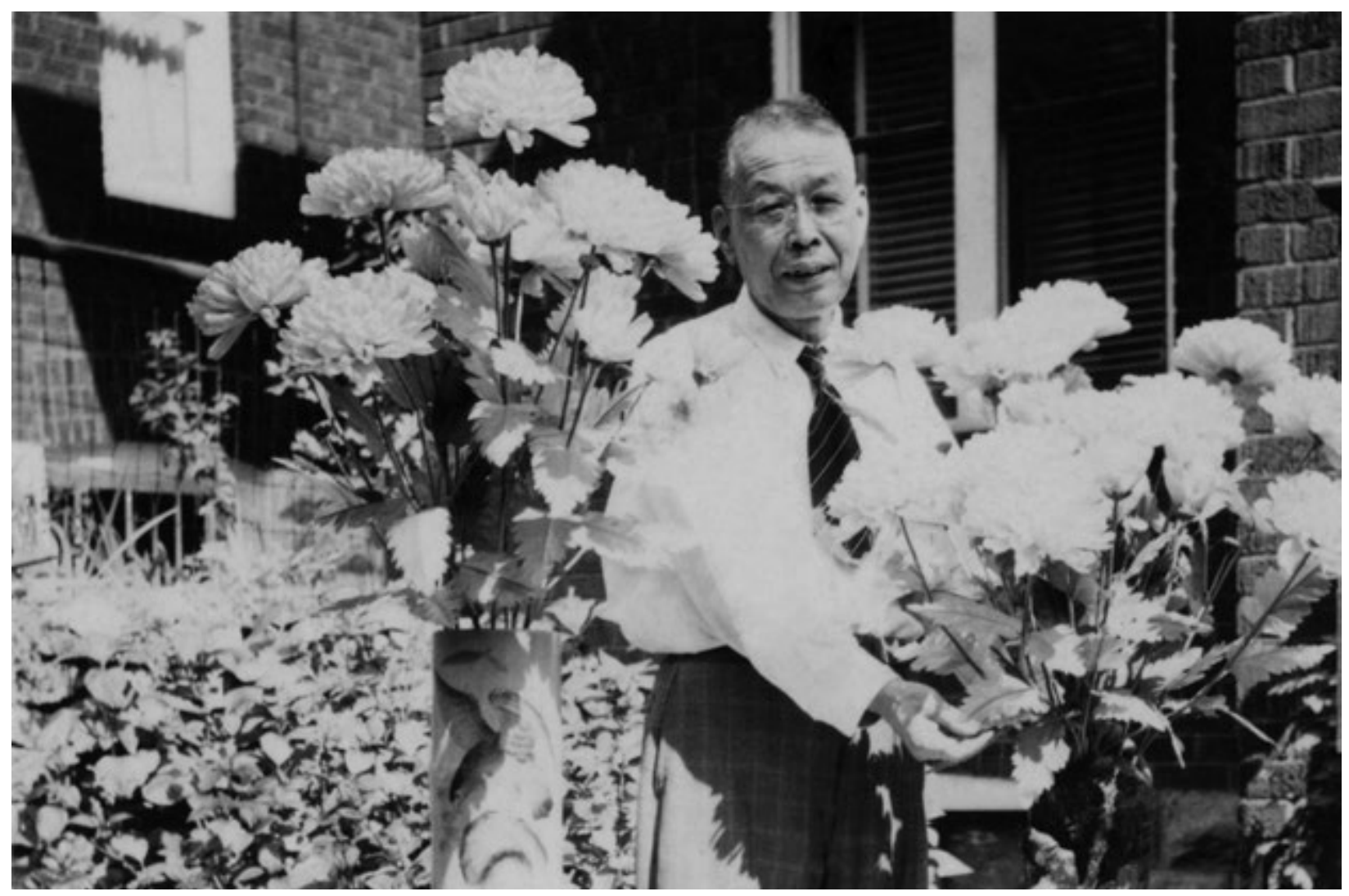

On April 10, 1958, my mother left for Japan because her brother-in-law, Eikichi proudly displayed beautiful chrysanthemums at his Toronto home. Kametaro Nakagawa was ill. My sister, Kimiyo, and her son, Bryan, went to Japan on June 17. After visiting relatives and friends and sightseeing, my mother returned to Toronto on July 12 . Most of that summer, my father was home by himself and, as he put it, "felt lonely."

My father kept himself busy making artificial flowers. He learnt this art while working in Osaka in his youth. Soon after he arrived in Canada, he made them to earn a little extra money. In Minto and in Toronto he made them before and after the gardening season. He had a license in Toronto to manufacture, in his home, artificial flowers for sale. In February 1946, he sold some to the Eaton's department store. They liked his flowers and over the succeeding 
3 Sato, [Teaching Japanese-Canadian Children for 50 years], 1969.

4 The New Canadian, March 3, 1960, Japanese Section.

5 Recollections by Mary Hyodo McCracken. months bought a "substantial quantity" to use in their display windows. He delivered them himself to the downtown Eaton store by taking the streetcar.

He made his own tools by forming nail heads held in a wooden handle. Silk remnants were coloured using vegetable dyes. He used an old curling iron heater to heat the tool used to shape the petals. Over the years, my father had experimented with tools and raw materials to make the artificial flowers easier to assemble and look more realistic. Mr. Tsutae Sato, the former principal of the Japanese Language School in Vancouver, and others came to our home to learn how to make artificial flowers such as chrysanthemums, roses, and peonies. ${ }^{3}$

A family friend would send matsutake mushrooms from BC to Toronto. My mother usually made matsutake maze gohan in which this delicacy is cooked, cut into small pieces and mixed with rice. This was a treat for the family. After every meal, my father would go to the living room, sit in his favourite chair and light up a cigarette. One writer described him as "an awesome chainsmoker." ${ }^{4}$ A granddaughter recalls: ${ }^{5}$

I remember how grandpa used to sit in the arm chair smoking when we came to visit. When the weather was good, grandpa often did his smoking in the driveway. I was encouraged to take my first puff there.

My children remember sitting on his lap and getting "humbug" candy. My mother enjoyed watching the I Love Lucy show on TV. She did not have to understand the English dialogue to laugh at the hilarious situations and humour. My father did not watch TV.

Before World War II, my father financially helped numerous students attend university. Chikao Hori, who received his medical degree with my father's help, sent him a basket containing an assortment of liquors every year after the war in appreciation. Later, he sent a large poinsettia plant every Christmas until my father passed away. In another case, where a student was not told of my father's help, the mother periodically brought whatever money she could spare to our home to repay my father. My father was moved by these actions over the years. 


\section{Family Gatherings}

We all looked forward to family gatherings on New Year's Day, our parents' birthdays, and Christmas. My mother prepared our favourite dishes. As the children got married, each family would bring a dish. There were as many as 12 adults and 16 children present depending on who came. Takako's family of five who lived in Houston, Texas, were the only ones that couldn't attend. Everyone got caught up on family news. After dinner, some of the adults, including my parents, played bridge while the rest played other games.

Our parents celebrated their 5oth wedding anniversary in September 1960. We had a special family get together. After a delicious dinner, we gathered in the living room where my parents cut their 5oth anniversary cake. My father had tears in his eyes. Everyone took pictures to record this special event. On other visits, when there was a smaller crowd, my father enjoyed cooking sukiyaki using an electric frying pan on the table. He greased the pan with fat and cooked the thinly sliced beef. Then he added broth, soy sauce, and sugar, and later an assortment of vegetables-the ones requiring the most time to cook were added first. Tofu and other ingredients were also added. Sukiyaki was served in small bowls and if you preferred, the bowl had a beaten raw egg. This delicious dish was one of our favourites.

My parents attended the Wakayama Prefecture picnic at High Park. There, they met old friends and visited with them. The children had races and games to keep them busy. There was plenty of delicious Japanese food everyone brought for bento to eat during the day. This is one event everyone looked forward to every year.

During an interview, Mr. Iwasaki, a well-known Japanese newspaperman, wrote: 6

Mr. Kagetsu is now 77 years old and retired. The hand he proffers for a handshake is soft and warm like a baby's. But with this hand before the war he built up the "Timber Kingdom." It is not an exaggeration to say that there is not a single Issei who does not know his name. President of the Canadian Japanese Association concurrently for well over a decade, President of Hompa Buddhist Temple, Principal of Middle School, there is no end to the titles he has held. "It was a very masculine type of work" says Mr. Kagetsu without a hint of regret in his expression. This comes from a feeling of contentment that he worked himself to the hilt.

6 The New Canadian, March 3, 1960, Japanese Section. 


\section{A Peaceful End}

My dad died peacefully in his sleep on January 27,1967 at the age of $83 .{ }^{7}$ The funeral was held at the Toronto Buddhist Temple. He was well-known and respected, especially by the old-timers, and hence the Temple was crowded to overflowing. Rev. Ishiura led the service. Rev. Kenryu Tsuji flew in from San Francisco and gave the eulogy. As is the custom in the Buddhist Church, my father was given a Buddhist name (hōmyō), "Shaku Yutoku," by Rev. Ishiura. Takako's husband, who is Chinese, thanked those who attended in impeccable Japanese that he learned during the Japanese occupation of Taiwan. Bryan Takahashi, Stanley Kagetsu, Akira Kagetsu, Tadashi Kagetsu, Masao Hyodo, and Henry Ide were the pall bearers and represented each family. My father was survived by his wife, four sons, four daughters, and by nineteen grandchildren.

The following are excerpts from some of the many condolence letters received. My father's sister, Kiku wrote:

... to think that this son of a farmer was invited by the Imperial Household in 1940. There were many articles in newspapers calling him "Timber King."

And to my mother she said:

Knowing my authoritative brother, I really want to thank you for all the behind-the-scene work you did to help him.

Mr. Yoshikane Shimazaki, the Mitsui Company's representative with whom he worked at the Ocean Timber Company, wrote:

I recall his smiling face smoking a pipe-exuding warm-heartedness. At the Vancouver Island camp, he taught me so much, the memories of those days will be forever cherished.

Juzo Suzuki, the editor of Canada Daily News, wrote,

... because of his innumerable initiatives and accomplishments at Canadian Japanese Association, Hompa Buddhist Church, and the Middle School for Japanese language, also his achievements in the
7 The New Canadian, February 4, 1967; February 7, 1967, Japanese Section. 
financial and labour areas, the Nisei, Sansei, and generations to follow will reap great benefits. It is my wish that his long-lasting contributions will be remembered and celebrated.

Nishi Honganji, the Head Temple in Kyoto, bestowed a special title or Ingo on my father in recognition of a life dedicated to the Church. The special title, Jushin In (forest and great mind) was a fitting tribute for an outstanding Japanese Canadian. Please see the calligraphy on page 97 for the original Japanese. 


\section{Bibliography}

Adachi, K. (1958). A History of the Japanese Canadians in British Columbia 1877-1958. Toronto: National Japanese Canadian Citizens Association.

Adachi, K. (1976). The Enemy That Never Was: A History of the Japanese Canadians. Toronto: McClelland and Stewart.

Adachi, P. (1992). Asahi, A Legend In Baseball: A Legacy from the Japanese Canadian Baseball Team to its Heirs. Etobicoke, ON: Asahi Baseball Organization.

Andersen, D. (1979). Evergreen Islands: Islands of the Inside Passage, Quadra to Malcolm. Sidney, BC: Gray's Publishing Ltd.

Armor, N., \& Gonnami, T. (2000). Historical Materials of Japanese Immigration to Canada, Supplement. English Section. Tokyo: Fuji Publishing.

Backus, H. F. (1969). Tomboy Bride. Boulder, CO: Pruett Press.

Bernard, E. (1977). A University at War: Japanese Canadians at UBC during World War II. BC Studies, 35, 36-55.

Bix, H. P. (2000). Hirohito and the Making of Modern Japan. New York: Harper Collins. 
British Columbia Fisheries Commission. (1922). Report and Recommendations. Ottawa: F. A. Acland, Printer to the King's Most Excellent Majesty.

British Columbia Security Commission. (1942). Report on the Removal of Japanese From Protected Areas. Vancouver.

British Security Coordination. (1942). Report on Japanese Activities in British Columbia. (n.p.).

Broadfoot, B. (1977). Years of Sorrow, Years of Shame: The Story of the Japanese Canadians in World War II. Toronto: Doubleday Canada.

Canada, Parliament, House of Commons Debates, (Hansard). 22nd Parliament, 1st session. Official Reports. Vol VI, 1953-54 (June 16, 1954), p. 6094-6098 (Hon. MacInnis).

Canadian Encyclopedia, (1988). Edmonton, AB: Hurtig Publishers.

Canadian Japanese Association, [1923]. B.C shū-nai ni okeru hōjin no keizai jōtai (Gairyaku) [Economic Conditions of Japanese in B.C. General Overview]. [Vancouver, BC].

Canadian Japanese Association, (n.d.). Gyogyō mondai [Fisheries Problems]. [Vancouver].

Canadian Japanese Association, (n.d.) Untitled Internal Report on Forestry Problem [In Japanese]. [Vancouver].

Canadian Japanese Association, (n.d.). Untitled Internal Report on General Highlights [In Japanese]. [Vancouver].

Canadian Japanese Association. (1923). Zaika Doho Rodo Chosa [Labour Survey of the Japanese in Canada]. Vancouver.

Canadian Japanese Association. (1927). Few Facts about Japanese School Children in Canada. Vancouver. 
Canadian Japanese Association. (1935). Report of the Survey of the Second Generation Japanese in British Columbia. Vancouver.

Canadian Japanese Association. (1937). Annual Report. (n.p.).

Canadian Japanese Association. (1938). Survey of Japanese in Canada. Vancouver.

Canadian Japanese Association. (1940a). Annual Report. (n.p.).

Canadian Japanese Association. (1940b). The Japanese Contribution to Canada: A Summary of the Role Played by the Japanese in the Development of the Canadian Commonwealth. Vancouver.

Canadian Japanese Association: Kanada zairyū hōjin chōsahyō, Shōwa 13nen 4-gatsu genzai [Survey Tables of Japanese in Canada, as of April 1938]. Vancouver.

City of Vancouver Directory. (1906, 1907, 1912). Vancouver: Henderson Publishing.

Davis, C. (1997). The Greater Vancouver Book: An Urban Encyclopaedia. Surrey, BC: Linkman Press.

Dawe, H. (1990). Helen Dawe's Sechelt. Madiera Park, BC: Harbour Publishing.

De Garis, F. (1950). We Japanese: Being Descriptions of Many of the Customs, Manners, Ceremonies, Festivals, Arts and Crafts of the Japanese Besides Numerous Other Subjects. Miyanoshita, Japan: Fujiya Hotel.

Canada, Department of Labour. (1944). Report on Administration of Japanese Affairs in Canada, 1942-1944. Ottawa, ON.

Canada, Department of Labour. (1947). Report on Reestablishment of Japanese in Canada 1944-1946. Ottawa, ON. 
Dower, J. W. (1979). Empire and Aftermath: Yoshida Shigeru and the Japanese Experience, 1878-1954. Cambridge, MA: Council on East Asian Studies, Harvard University.

Dower, J. W. (1999). Embracing Defeat: Japan in the Wake of World War II. New York: W.W. Norton.

Draycott, W. M. (1978). Early Days in Lynn Valley. North Vancouver, BC: North Shore Times.

Drushka, K. (1992). Working in the Woods: A History of Logging on the West Coast. Madeira Park, BC: Harbour Publishing.

Drushka, K. (1995). HR: A Biography of H.R. MacMillan. Madeira Park, BC: Harbour Publishing.

Eagles, B. A. (1957, March 31). Makers of the University: Leonard Sylvanus Klinck, UBC President 1919-1944. Alumni Chronicle, pp. 24-5.

Enders, T. (2009). The Tale of Tanquille. Retrieved from http://legiontvs44.com/wp-content/uploads/2009/07/the-tale-oftranquille.pdf

Fireflies, snow and "Auld Lang Syne." (1998). Japanese Philately, 53(5), 250.

Fowke, E. (1951). They Made Democracy Work: The Story of the Cooperative Committee on Japanese Canadians. Toronto: Japanese Canadian Citizens' Association.

Francis, D. (200o). Encyclopedia of British Columbia. Madeira Park, BC: Harbour Publishing.

Frisby, B. E. (1963, August 17 - September 11). Treatment of the J.C.'s During World War Two. The New Canadian. Seven installments. Note: Chapters III through VII were published in The New Canadian December 22, 1955 through October 30, 1957 in 21 instalments.

Glover-Geidt, J. (1990). The Friendly Port: A History of Union Bay, 1880-1960. Union Bay, BC: D.R. Geidt. 
Gold, W. (1985). Logging as it Was: A Pictorial History of Logging on Vancouver Island. Victoria, BC: Morriss Publishing.

Gonnami, T. (1995). Kanada Shimbun (The Canada Daily News) and Nikkan Minshu (The Daily People) for 1941 on Microfilm: A Preservation Microfilming Project at the University of British Columbia Library. Microfilm Review, 24(3), 117-123.

Gonnami, T. (2009). Tairiku nippo [The Continental Daily News], 1908-1941 on Microfilm. 18(1), 38-40. doi: 10.1515/mfir.1989.18.1.38

Gould, E. (1975). Logging: British Columbia's Logging History. Saanichton, BC: Hancock House Publishing.

Granatstein, J. L., \& Johnson, G. L. (1988). The Evacuation of the Japanese Canadians, 1942: A Realist Critique of the Received Version. In N. Hillmer, B. S. Kordan, \& L. Y. Luciuk, (Ed.), On Guard for Thee: War, Ethnicity and the Canadian State, 1939-1945 (pp. 101-129). Ottawa, ON: Canadian Committee for the History of the Second World War.

Green, M. T. (1992). Industrial Locomotives: A Catalogue of Locomotives and Lines. Vancouver: Pacific Coast Division, Canadian Railroad Historical Association.

Greenberg, S., McWhirter, N., \& McWinter, R. (1992). Guinness book of Olympic Records: Complete Roll of Olympic Medal Winners (1896-1988, Including 1906) for the Sports (7 Winter and 25 Summer) Contested in the 1992 Celebrations and Other Useful Information. New York: Bantam Books.

Haldane, J. W. C. (1900). 3800 Miles Across Canada. London, UK: Simpkin, Marshall, Hamilton, Kent \& Co.

Hatayama, K. (1940). Zaibei nihonjinshi [History of Japanese in North America]. San Francisco: Zaibei Nihonjinkai.

Hidaka, K. (1942). Legal Status of Persons of Japanese Race in Canada: Preliminary Investigation. (Unpublished theses). University of British Columbia, Vancouver, BC. 
Hieda, H. (1965). Wakayama kinjin kaigai jinzairoku: Hokubei, Kanada, Mekishiko [Directory of Wakayama Prefectural Expatriates: North America, Canada, Mexico]. Tokyo: Kishūsha.

Hoshō, K. (1929). Kōo bō Daishi ryakuden [A Brief Biography of Kūkai]. Kōya-san, Wakayama-ken: Kōbō Daishi Issenhyaku-nen Goenki Jimukyoku.

Hovis, L. W. (1986). Technological Change and Mining Labour: Copper Mining and Milling Operations at the Britannia mines, British Columbia, 1898-1937. (Master's thesis). University of British Columbia, Vancouver, BC.

Howard, I. (1973). Bowen Island 1872-1972. Victoria, BC: Morriss Publishing.

Hoyt, E. P. (1992). Hirohito: The Emperor and the Man. New York: Praeger Publishing.

Hundevad, J. (1936a). Guide Book of the Pilgrimage to Vimy and the Battlefields: July-August 1936. Ottawa, ON: The Veteran Ltd.

Hundevad, J. (1936b). Guide Book of the Pilgrimage to Vimy and the Battlefields: July-August 1936. [Supplement]. Ottawa, ON: The Veteran Ltd.

Ikuta, M. and A. Yamazaki (1981). Kanada Bukkyōkai enkakushi: Dainiji taisen izen no B.C. shū o chüshin ni [History of the Buddhist Church in Canada: Especially on pre-World War II B.C.]. Toronto: Kanada Bukkyō Kyōkai.

Isenor, D., McGill, M., \& Watson, D. (1980). For Our Children: A History of Comox Valley Schools, 1870-1980. Courtenay, BC: School Board District $\# 71$.

Isenor, D., Stephens, E. G., \& Watson, D. (1988). One Hundred Spirited Years: A History of Cumberland, 1888-1988. Campbell River, BC: Ptarmigan Press. 
Ito, K. (1973). Issei: A History of Japanese Immigrants in North America. (S. Nakamura \& J. S. Gerard, Trans.). Seattle, WA: Executive Committee for Publication of Issei.

Ito, R. (1984). We Went To War: The Story of the Japanese Canadians Who Served During the First and Second World Wars. Stittsville, ON: Canada's Wings.

Ito, R. (1994). Stories of My People: A Japanese Canadian Journal. Hamilton, ON: S-20 and Nisei Veterans Association.

Japanese Canadian Centennial Project. (1978). A Dream of Riches: The Japanese Canadians 1877-1977. Vancouver: Japanese Canadian Centennial Project.

Japanese Canadian Citizens' League. (1936, February 13). Organizational Meeting of the Japanese Canadian Citizens' League. Vancouver, BC.

Japanese Canadian Citizens' League. (1936, February 17, March 4-5, April 21). The Executive Meetings of the Japanese Canadian Citizens' League. Vancouver, BC.

Justice H. I. Bird and Canada, Royal Commission to Investigate Property Claims of Japanese Canadians Evacuated from Coast Areas of British Columbia in 1942. (1950). Report Upon the Investigation into Claims of Persons of the Japanese Race Made ... Pursuant to the Terms of Order-inCouncil P.C. 1810 of July 18th, 1947, as Subsequently Amended, Ottawa: The Commissioner. Located at (Box 8, File 8). TFRBL, F.G. Shears Collection, Thomas Fisher Rare Book Library, University of Toronto.

Kagetsu, H. (1942). Motor Trucks as Feeders to Railroads. (Bachelor Honours thesis). University of British Columbia, Vancouver, BC.

Kagetsu, H. (1954, February 10). Lower Canadian Tariffs and Japanese Product. No. 50. Tokyo: Tokyo Trade Association (Foundation).

Kagetsu, K. (n.d.). Watakushi no Jinsei [My Life]. (n.p.). 
Kahrer, A. G. (1988). Logging and Landscape Change on the North Shore of Burrard Inlet, British Columbia, 1860's to 1930's (Master's Thesis). Vancouver, BC: University of British Columbia.

Kahrer, G. (1989). From Speculative to Spectacular: The Seymour River Valley, 1870's to 1980's: A History of Resource Use. Burnaby, BC: Greater Vancouver Regional District Parks Dept.

Kawasaki, Zeisei. (1992) Omoide no mamani [As I Remember] Draft of Memoirs.

Kennedy, M. D. (1963). A Short History of Japan. Toronto: The New American Library of Canada.

Kloppenborg, A., Niwinski, A., \& Johnson, E. (Eds.). (1991). Vancouver, A City Album. Vancouver: Douglas \& McIntyre.

Kluckner, M. (1984). Vancouver the Way it Was. Vancouver: Whitecap Books.

Kobayashi, Audrey, (n.d.). Issei Life Histories: An Interactive Data Base on Japanese Canadian History, Online database. Located at the Japanese Canadian National Museum and Archives.

Kōbō Daishi goichidaiki [The Life of Kūkai]. (1952). Kōya-san, Wakayamaken: Kōya-san Butsugu Meisanhin Kumiai.

Kodansha, (1983). Kodansha Encyclopedia of Japan. New York: Kodansha.

Krause, J. A. (1997). The Life and Times of the Comox Valley, Region of Vancouver Island, British Columbia, Canada. Courtenay, BC: C.C. Sotel.

La Violette, F. E. (1948). The Canadian Japanese and World War II: A Sociological and Psychological Account. Toronto: University of Toronto Press.

Leonard, J. N. (1968). Early Japan. New York: Time-Life Books. 
Lett, S. (1934, December). The Legal Disabilities of the Japanese Canadians in Canada. Proceedings and Transactions of the Japanese Students' Club of the University of British Columbia, 1(1).

Levitz, R., \& Willott, L. (1997). Images and Voices of Lighthouse Country: A Pictorial History of Deep Bay, Bowser, Qualicum Bay, Horne Lake. Browser, BC: Images \& Voices.

Leyshon, G. A. (1988) Judoka: The History of Judo in Canada. Gloucester, ON: Judo Canada.

Macdonald, B. (1992). Vancouver: A Visual History. Vancouver: Talon Books.

Martin, C. (1967). The Russo-Japanese War. New York: Abelard-Schuman.

Meiji Tennō Oshashinchō Kankōkai. (1927). Taishō tennō oshashinchō [Photo Album of Emperor Taisho]. Tokyo: Meiji Tennō Oshashinchō Kankōkai.

Meiji Tennō Oshashinchō Kankōkai. (1929). Meiji tennō oshashinchō [Photo Album of Emperor Meiji]. Tokyo: Meiji Tennō Oshashinchō Kankōkai.

Miki, R. \& Kobayashi, C. (1991). Justice in Our Time: The Japanese Canadian Redress Settlement. Vancouver: Talonbooks.

Ministries of Foreign Affairs and Overseas Affairs. (1940). Kigen NisenRoppyaku-Nen Dai-lkkai Zaigai Dobo Daibyosha Kaigu Gijiroku [The Proceedings of the First Conference of Delegates of Fellow Japanese Abroad in the 26ooth Year of the Imperial Reign]. Tokyo: (n.p.).

Ministry of Foreign Affairs. (1975). Kaigai de katsuyaku suru nihonjin no sugata sono san [Profiles of Japanese Active Overseas Part 3]. Japan: Gaimusho Ryoji Ijubu.

Mitsui, T. (1967). The Ministry of the United Church of Canada among Japanese Canadians in British Columbia (Master's thesis). Union College of British Columbia, Vancouver, BC.

Miyazaki, M. (1973). My Sixty Years in Canada. Lillooet, BC. 
Miyazaki, N. (Ed.). (1928). Kōbō Daishi no hoon shugi [Ethical Teachings of Kūkai]. Kōya-chō, Wakayama: Kōbō Daishi Issen-hyakunen Goonki Jimukyoku.

Moritsugu, F., \& Ghost-Town Teachers Historical Society. (2001). Teaching in Canadian Exile: A History of the Schools for Japanese-Canadian Children in British Columbia Detention Camps During the Second World War. Toronto: Ghost-Town Teachers Historical Society.

Muckle, B. (2001). The Seymour Valley Archaeology Project. The Midden, $33(2), 2-3$.

Murray, W. W. (1936). The Epic of Vimy. Ottawa, ON: The Legionary.

Nakamoto, J. (1954). Mate in 34 Moves: Jack Kagetsu Defeats World Chessmaster. Scene: The International East-West Magazine.

Nakayama, J. (1921a). Kanada doho Hatten Taikan: Zen [Encyclopaedia of the Japanese in Canada: Complete]. Tokyo, Japan: The Japan Times.

Nakayama, J. (1921b). Kanada no Hoko [The Treasure House of Canada]. Tokyo.

Nakayama, J. (1922). Kanada doho Hatten Taikan: Furoku [Encyclopaedia of the Japanese in Canada: Supplement]. Tokyo.

Nakayama, J. (Ed.). (1940). Kanada to Nihonjin [Canada and the Japanese]. Vancouver: Kanada Nihonjin Kai \& Eikichi Kagetsu. See Armor, 2000. For translation by Tsuneharu Gonnami, Asian Library, University of British Columbia.

National Association of Japanese Canadians. (1985). Economic Losses of Japanese Canadians After 1941: A Study. Winnipeg. MB: National Association of Japanese Canadians.

Niija, B. (Ed.). (1993). Japanese American History: An A-to-Z Reference from 1868 to the Present. New York: Facts on File. 
Nimi, B., Nimi, P., Umemoto, K., \& Furukawa, E. (1992). Sentimental Journey. Vancouver: The Reunion Committee.

Nishihama, H. (March 1993). "Kanada imin no chichi: Kuno Gihei [The Father of Canadian Immigrants: Gihei Kuno].” Ijū Kenkyū, 30, 170-184.

Norton, W. (1999). A Whole Little City by Itself: Tranquille and Tuberculosis. Kamloops, BC: Plateau Press.

O-kyu de byoki wo naosu hippo [Secret Method of Healing Sickness with Moxabustion]. (1933). Shufu no Tomo, 17(2). Furoku.

Olsen, Arv. (2004). Shingles and Shells, A History of Fanny Bay. Victoria: Fanny Bay Old Age Pensioners No. 127.

Omatsu, M. (1992). Bittersweet Passage: Redress and the Japanese Canadian Experience. Toronto: Between the Lines.

Osterhout, S. S. (1929). Orientals in Canada: The Story of the Work of the United Church of Canada with Asiatics in Canada. Toronto: Ryerson.

Potter, J. D. (1967). Yamamoto: The Man who Menaced America. New York: Paperback Library.

Rajala, R. A. (1987). Lumbering at the Lake: The Cowichan Lake Lumber Industry, 1900-1950. A Report Prepared for the Cowichan Lake Heritage Advisory Committee. Victoria, BC.

Renshū Kantai Hensan Iin (Ed.). (1914). Dai 41-kai Renshū Kantai enkō kinen [Commemoration of the 41st Expedition of the Training Fleet]. Tokyo: Gahōsha.

Renshū Kantai Hensan Iin (Ed.). (1917). Taishō 6-nen Renshū Kantai enkō kinen [Commemoration of the Taisho 6th Expedition of the Training Fleet]. Tokyo: Gahōsha.

Rikugun Bijutsu Kyōkai. (1939). Seisen bijutsu [Sacred War Art] [exhibition catalogue]. Kyoto, Japan: Rikugun. 
Roberts Creek Historical Committee. (1978). Remembering Roberts Creek, 1889-1955. Madeira Park, BC: Harbour Publishing.

Robinson, S. (1923). Official Report on the Japanese Earthquake, the Fire and Subsequent Relief Operations. (n.p.).

Roy, P. E. (1989). A White Man's Province: British Columbia Politicians and Chinese and Japanese Immigrants 1858-1914. Vancouver: University of British Columbia Press.

Roy, P. E., Granatstein, J. L., Iino, M., \& Takamura, H. (1990). Mutual Hostages: Canadians and Japanese During the Second World War. Toronto: University of Toronto Press.

Rushton, G. A. (1978). Whistle up the Inlet: The Union Steamship Story. Vancouver: Douglas \& McIntyre.

Russo-Japanese War. (1959). Chicago, IL: Encyclopaedia Britannica.

Saita, H. S. (1884-1975). The Brief History of the First J.C.C.A. (R3135-O-o-E, Vol. 1, Case file 4). Library and Archives Canada, Ottawa, Canada.

Sakaguchi, M. (July 1992). The Japanese Clinic in Vancouver, 1932-1942. The Study of Christianity and Social Problems, 41, 90-101.

Sasaki, S. S. (n.d.). Outline of the Development of Judo in Canada. Unpublished manuscript.

Sasaki, T. (1992, July). The Japanese Association of Canada: Its Democratic Reform and the Destruction of its Democratic System by Vancouver Consul Kaai. The Study of Christianity and Social Problems, XLI, 63-9o.

Sato, T., \& Sato, H. (1969). Kodomo to tomo ni gojūnen: Kanada nikkei kyōiku shiki [Teaching Japanese-Canadian Children for 50 Years]. Tokyo: Nihon Shuppan Bōeki.

Saywell, J. F. T., (1967). Kaatza, the Chronicles of Cowichan Lake. Sidney, BC: Cowichan Lake District Centennial Committee. 
Scantland, A. C. (1986). Study of Historical Injustice to Japanese Canadians. Vancouver: Parallel Publishers.

Seidensticker, R. (1962). Japan. Life World Library. New York: Time-Life Books.

Shakespeare, M. \& Pain, R. H. (1977). West Coast Logging 1840-1910. Ottawa, ON: National Museums of Canada.

Shibata, Y., Matsumoto, S., Hayashi, R., \& Iida, S. (1977). The Forgotten History of the Japanese Canadians (Vol. 1). Vancouver: New Sun Books.

Shibayama, T. (1941a). Nisen ryoppyaku-nen kaigai dobo daibyo o mukaete [Welcoming Fellow Japanese Abroad in the 26ooth Year of the Imperial Reign]. Association for Japanese Colonization: (n.p.).

Shibayama, T. (Ed.). (1941b). Welcoming Representatives of Japanese in Foreign Countries: 26ooth Year of Imperial Reign. (n.p.): Japan Overseas Affairs Association.

Shinobu, S. (1936). The Vimy Ridge Pilgrimage. (MG28v7 Vol 16 File 3. JCCA Fonds). Library and Archives Canada, Ottawa, Canada.

Stevenson, W. (1976). A Man Called Intrepid: The Secret War. New York: Harcourt Brace Jovanovich.

Stinnett, R. B. (1999). Day of Deceit: The Truth about FDR and Pearl Harbor. New York: Free Press.

Sugiman, M. (Ed.), \& Ad Hoc Committee for Japanese Canadian Redress. (2000). Japanese Canadian Redress: The Toronto Story. Toronto: $\mathrm{HpF}$ Press.

Sumida, R. (1935). The Japanese in British Columbia (Master's thesis). University of British Columbia, Vancouver, BC.

Sunahara, A. G. (1981). The Politics of Racism: The Uprooting of Japanese Canadians During the Second World War. Toronto: James Lorimer. 
Svinth, J. R. (2003). Getting a Grip: Judo in the Nikkei Communities of the Pacific Northwest, 1900-1950. Guelph, ON: EJMAS.

Tairiku Nippo Sha. (Ed.). (1924). Kanada zairyu hojin jimeiroku: Kanada Doho Hatten Shi, 3 [Japanese in Canada, 3rd Edition]. Vancouver: Tairiku Nippo Sha.

Tairiku Nippo Sha. (Ed.). (1941). Zai Kanada Hojin Jinmeiroku [Directory of the Japanese in Canada]. Vancouver: Tairiku Nippon Sha.

Tairiku Nipposha (Ed.). (1924). Commemorating the Marriage of His Imperial Highness. Vancouver.

Takahashi. (1995, May). Zairyū hōjin no no.1, Kagetsu Eikichi-ō to kataru [Interview with Venerable Eikichi Kagetsu, no. 1 Among Japanese Canadians]. Yomimo Ringyō, 21(5), 16-18.

Takata, T. (1983). Nikkei legacy: The Story of Japanese Canadians from Settlement to Today. Toronto: NC Press.

Tanaka, T. (1990). Hands Across the Pacific: Japan in British Columbia, 18891989. Vancouver: Consulate General of Japan.

Tenkai, R. (1956). Oogiku no tsukuri kata [How to Cultivate Large Chrysanthemums]. (n.p.).

The "ABC" British Columbia Lumber Trade Directory and Year Book. (19261940). Vancouver: Progress Publishing.

The Bridge World. (1989).

Tsuji S. (1990). Japanese Cooking: A Simple Art. New York: Kodansha International.

Tuomala, M. F. (1960). The Evolution of Logging in the West Coast. (Bachelor's thesis). University of British Columbia: Vancouver, BC. 
Turner, R. D. (1981). The Pacific Empresses: An Illustrated History of the Canadian Pacific Railway's Empress Liners on the Pacific Ocean. Victoria, BC: Sono Nis Press.

Turner, R. D. (1990). Logging by Rail: The British Columbia Story. Victoria, BC: Sono Nis Press.

Wangenheim, E. D. (1963). The Social Organization of the Japanese Community in Toronto (Master's thesis). University of Toronto, Toronto, ON.

Ward, W. P. (1978). White Canada Forever: Popular Attitudes and Public Policy Toward Orientals in British Columbia. Montreal: McGill-Queens University Press.

Warner, D., \& Warner, P. (1974). The Tide At Sunrise: A History of the RussoJapanese War, 1904-1905. New York: Charterhouse.

Watada, T. (1996). Bukkyo Tozen: A History of Jodo Shinshu Buddhism in Canada, 1905-1995. Toronto: HpF Press \& the Toronto Buddhist Church.

Westwood, J. N. (1986). Russia Against Japan, 1904-05: A New Look at the Russo-Japanese War. New York: SUNY Press.

White, H. (1983). Raincoast Chronicles Six/Ten. Madeira Park, BC: Harbour Publishing.

Wrigley's British Columbia Directory. (1925-1927). Vancouver: Wrigley Directories.

Wyngaert, Frank, (n.d.). Bert Whitaker Selling Beach Gravel to Champion and White. Handwritten/Unpublished article.

Yamazaki, Y. (Ed.). (1942). Sokuseki [Footprint]. Tokyo: O Denki Hensankai.

Yokota, N. (1994). Pioneers Anonymous. Capilano College: North Vancouver, BC. 
Yoshida, R. (Ed.). (1926). Zai Kanada Hojin Jinmeiroku [Directory of the Japanese in Canada]. Vancouver: Tairiku Nippo Sha.

Young, C. H., Reid, H. R. Y., \& Carrothers, W. A. (1938). The Japanese Canadians. Toronto: University of Toronto Press.

Yura-cho Tsu-shi Tien. (n.d.). Yura-cho shi gekan [History of Yura Town, Volume 2]. (n.p.). 
APPENDIX |

\section{List of Fanny Bay Residents (1942)}

Asao, Tsuneto

Asao, Yasa

Asao, Grace

Fujimoto, Hideo

Fujimoto, Satoshi

Furukawa, Bunshiro

Goto, Eisuke

Gyoba,Takeo

Gyoba, Misami

Gyoba, Toshinori

Gyoba, Chiyeko

Gyoba, Hiroko

Hamanaka, Masatsugu

Hamanaka, Yakuzo

Hamanaka, Hisako

Hamanaka, Seiichi

Hamanaka, Kikuko

Higano, Denkichi

Higano, Masa

Higano, Aya

Horie, Kaichi

Inouye, Yoshitomi
Irizawa, Sawaichi

Irizawa, Shizuka

Irizawa, Tamako

Irizawa, Masaki

Irizawa, Kuniko

Irizawa, Haruko

Irizawa, Sachiko

Ito, Hanichi

Ito, Sakaye

Ito, John

Izawa, Mitsuo

Izawa, Shigeno

Izawa, Tomio

Izawa, Iwao

Kagetsu, Tsurutaro

Kagetsu, Hide

Kagetsu, Susumu

Kagetsu, Natsuko

Kagetsu, Yoshiko

Kagetsu, Tsuyuko

Kagetsu, Reiko

Kagetsu, Tetsuo
Kawasaki, Sanjiro

Kariya, Ichitaro

Kida, Yoshimitsu

Kikuchi, S.

Kikuchi, Fujiko

Kikuchi, Tsutomu

Kikuchi, Fumiko

Kireto, Gunichi

Kireto, Misa

Kireto, Kimiko

Kireto, Shigeru

Kireto, Toshio

Kumagaya, Jiro

Kumagaya, Mitsu

Matsunaga, Keiji

Matsunaga, Takashi

Matsunaga, Shizuo

Matsunaga, Sawayo

Matsunaga, Yoichi

Matsunaga, Takuj i

Minato, Yoshikichi

Minato, Masano 


\begin{tabular}{lll} 
Minato, Yoshitaro & Sakai, Seiichi & Tsuruda, Hisao \\
Miyamoto, Jisaku & Suenaga, Fukuichiro & Tsuruda, Shizuye \\
Murai, Masazo & Suenaga, Toshiko & Tsuruda, Masao \\
Murai, Kofuji & Suenaga, Mitsue & Tsuruda, Shoji \\
Murai, Yoshio & Suenaga, Masako & Tsuruda, Hiroyuki \\
Murai, Kazuo & Suenaga, Hiromu & Tsuruda, Yayoi \\
Murai, Tsutomu & Suenaga, Shigeo & Tsuruda, Tomi \\
Murai, Takako & Sugimoto, Hiroshi & Yamada, Iwao \\
Murai, Masaru & Sumida, Tameji & Yamada, Sumako \\
Murakami, Yoshio & Suzuki, Takashi & Yamada, Shirley \\
Murakami, Jitsuko & Suzuki, Naomi & Yamauchi, Kiyomitsu \\
Murakami, Osami & Suzuki, Hideo & Yano, Mutsukiyo \\
Murakami, Narumi & Takashima, Yoshitaka & Yano, Sumiye \\
Nakamura, Hisao & Takashima, Yoshiye & Yano, Saburo \\
Nakamura, Haruko & Takashima, Hajime & Yano, Masaru \\
Nakamura & Takashima, Mitsuye & Yano, Fumiko \\
Nakano, Eiko & Tanaka, Isaburo & Yano, Noboru \\
Nakano, Umeo & Tanaka, Yoshino & Yano, Hiroshi \\
Nakano, Mineo & Tanaka, Toshihiro & Yoshida, Nobushige \\
Niinaka, Niichi & Tanaka, Michiyo & Yoshida, Tomo \\
Niinaka, Sada & Tanaka, Hideo & Yoshida, Tamotsu \\
Niinaka, Shigeru & Tanaka, Hiroyuki & Yoshida, Hisako \\
Niinaka, Taeko & Tanaka, Kayoko & Yoshida, Yuriko \\
Nishi, Toshinami & Tanaka, Mutsuko & Yoshida, Minoru \\
Okawa, Kiyoshi & Tominaga, Yoshishichi & Yoshida, Midori \\
Okawa, Fumi & Tominaga, Kikue & \\
\hline
\end{tabular}

List compiled by Rev. Yoshio Ono for the B.C. Security Commission.

Source: University of British Columbia Main Library Special Collections. 


\title{
APPENDIX II \\ Canadian Japanese Association
}

\author{
List of Presidents \\ 1909-1917 Yasushi Yamazaki \\ 1918 Issetsu Yamamoto \\ 1919-1921 Matsunoshin Abe \\ $1922 \quad$ Koichiro Sannomiya \\ 1923 (Acting) Ritsu Ide \\ 1924-1925 Yataro Arikado \\ 1926-1930 Eikichi Kagetsu \\ 1931 (Acting) Bunji Hisaoka \\ 1932-1933 Toyozo Matsuyama \\ 1934-1935 Eikichi Kagetsu \\ 1936 Tomijiro Nishikawa \\ 1937-1940 Eikichi Kagetsu \\ 1941 Bunji Hisaoka
}




\section{Officers (1940)}

$\begin{array}{ll}\text { President: } & \text { Eikichi Kagetsu } \\ \text { Vice President: } & \text { Bunji Hisaoka } \\ \text { Chairman (Gi-cho): } & \text { Giichi Nakayama } \\ \text { Vice Chairman: } & \text { Tokichi Takeuchi } \\ \text { Treasurer: } & \text { Seijiro Miyazaki } \\ \text { Secretary: } & \text { Yutaka Kawata }\end{array}$

Reference: Hatayama, K. (1940). Zaibei nihonjinshi [History of Japanese in North America]. San Francisco: Zaibei Nihonjinkai, pp. 1043-1044. 


\section{APPENDIX III \\ Speech by \\ Eikichi Kagetsu, Representative from Canada}

\section{Delivered on November 7, 1940 to the First Conference of Representatives}

of Overseas Japanese to Celebrate the Year 2600.

Earlier, I was asked to speak frankly, and I feel somewhat delighted. In inviting us to this conference, I felt that I was being rewarded for all the past hard work and that this has been recognized.

As for conditions in Canada, I will begin by going through the pages of the booklet that I have prepared for each of you. Although Canada is a very large country, its population is very small. Furthermore, it is underdeveloped. As a result, Canada tends to be forgotten. Whenever there is an event, many people regard letters from Canada as coming by way of North America. There are many people who still do not understand that Canada is Canada, a separate country. I would now like to talk a little about the history of Canada.

Canada was originally a colony of France. The colonial administration was greatly mismanaged. There were large landowners who ill-treated sharecroppers. On the religious side, the authorities insisted on their own religion and 
prohibited others. In the area of commerce, they insisted that trading ships fly the flag of France. The policy of the Colony was ultra-protectionism. These policies eventually led to a change from French rule to British rule in 1763. At about this time in the United States, war of independence was taking place. Those wishing to remain loyal to the British Crown and those with wealth escaped to Canada. The migration of these people increased the population of Canada. The population of "Mont Royal" in the east while under French rule was a mere 65,000 , but by 1800 , it swelled to some 400,000 .

After completely becoming a dominion under English rule, England divided Canada into East Canada and West Canada and exercised control of the country. By order of the King of England, a Governor General was dispatched to administer the colony. On the legislative side, there was the upper house and the lower house. The members of the upper house were appointed by the King, and the members of the lower house were elected from the people. When compared to the French administration, it was very liberal.

Currently, Canada is made up of 9 provinces and its population is 11,500,000. This figure is from census taken in 1930. Those of English descent comprise $35 \%$, Irish descent $-10 \%+$, French - 30\%, German and other European $-15 \%$. The remainder are from other countries of the world.

I will now move onto industry. As you know, the central portion of Canada is a vast prairie of some 1000 miles. The western section is the Rocky Mountains where there are unlimited amount of timber resources. In the forestry industry, Canada ranks third behind Russia and the United States. Total annual output of forestry products amounts to $\$ 163,000,000$. Agriculture is another important industry. The climate in the interior is continental whereas along the coast, it is moderate with much rain. The soil is very fertile. Wheat, oats, cereals, fruits, vegetables can be grown, some with very little caring and fertilizing. Annual output of other agricultural products such as livestock, poultry, furs, tobacco, etc. amounts to $\$ 1,020,000,000$.

As Canada faces the Atlantic Ocean in the east and the Pacific Ocean in the west, the oceans have both cold and warm currents that intermix. As a result, there are many types of fish. In the Atlantic, large quantities of cod, sardines, sole, mackerel, etc. are caught. In the Pacific, the main fish are cod, trout, salmon, herring and halibut. Their total annual catch amounts to $\$ 40$ to $\$ 50,000,000$. Salmon is mainly canned and shipped to Europe. The Japanese began salting salmon and herring and exporting them to Asian markets, but because of the current war in Europe, these exports have been banned. 
As for mineral resources, Canada ranks as No. 1 or 2. Canada produces gold, platinum, copper, nickel, asbestos, zinc, coal, etc. Their annual output is approx. $\$ 657,000,000$.

On the investment side, investment from England amounts to 2.7 billion dollars and from the United States, 3.9 billion dollars. Investment from U.S. is a little higher. Because of these investments, manufacturing industries have grown gradually. Sawn lumber, paper, pulp, foodstuffs, automobiles, textiles, furniture, instruments, etc. are produced and their value in 1937 was over $\$ 300,000,000$.

Turning to trade, according to statistics of 1938, the amount of exports from Canada was $\$ 969$ million and imports was $\$ 658$ million, leaving a net balance of $\$ 311$ million in Canada’s favor. In the same year (1938), exports to Japan was $\$ 21$ million, and imports from Japan was $\$ 4.5$ million. Canada is a raw material exporting country and Japan is a manufactured product exporting country, and this creates an abnormal trade balance. It is believed that this trade imbalance will continue for some time to come. There are approx. 23,00o Japanese living in Canada. Of these, approx. 20,000 live in the Pacific coastal province of B.C. The remaining 3,000 are scattered in other parts of the country. This province is like "fu" or "ken" of Japan and its land area is 1.5 times that of Japan. The climate in B.C. is similar to that of Japan and living here is comfortable. Where most Japanese live is in Vancouver and its vicinity.

In one area of Vancouver, there is a large Japanese town. Here, one can purchase general merchandise, groceries, medicines, etc. There are numerous "ryokans" (hotels), also restaurants and barber shops, etc. Residents can live here in a complete Japanese atmosphere.

There has already been 60 years of history of Japanese living here. To achieve the foundations and rights, it goes without saying that our compatriots faced many difficulties. As the compatriots live far away from their mother country and in a alien country, it is natural that they face difficulties. However long the time passes, discrimination never ceases. This discrimination never existed before. Discrimination first appeared in 1897. At first, it was how the Japanese should be treated. Probably they should be treated like so and so. Even today, more and more malicious discriminations are continuing.

Around 1879 or 1890, a few Japanese began fishing for salmon that they sold to local natives or others. Later by 1896 , several canning plants were built and employed many Japanese. Not only in fishing for salmon, but also in other fields, the Japanese were more talented and their skills surpassed those of the whites and native people. Given any task, the Japanese outperformed the others. Because of this industriousness, the Japanese acquired 3,100 licences of 
the total of 7,00o issued. In other words, there was a golden time when Japanese had $40 \%$ of the fishing licenses. Beginning in 1921, they gradually began to decrease the number. Even last year, they decreased the number of licenses. Although the decrease was authorized by cabinet order, we decided to take this case to court which resulted in a favorable decision for us. Currently, Japanese hold approx. $15 \%$ of the total licenses issued. Formerly, we had $40 \%$, and now only $15 \%$.

Next, I would like to talk about farming. In 1908, it is recorded that the consul at that time was Consul Yada. He recognized the importance of agriculture (farming) in Canada and recommended to our compatriots to go into farming. As a result, there are now approx. 1000 independent farmers. It follows that there are considerably more engaged in farming. Also in farming, their technology far exceed those of white farmers. They are skillful, very patient and are doing very well. As they maintain good relations with the white farmers, there are no discrimitory remarks raised against them.

Next I would like to talk about the forestry industry. At first, the Japanese started on a small scale with few workers. As the Japanese gradually become skilled, they became more productive than their white counterparts. This resulted in white owners hiring more Japanese. There were more than 2 thousand Japanese working in the industry by 1918 . However, in this industry, the government through Order-in-Council, prohibited Japanese from cutting trees on dominion or provincially owned lands. As a result, we took the government to court and obtained a decision that was favorable to us. At present, there are no Japanese cutting trees on crown owned lands. However, there are 5 to 6 Japanese who have bought large tracts of privately owned forested land and operating on a large scale and employing 5 to 6 hundred workers. The number of Japanese operated sawmills is about 5 or 6 . The number of Japanese working in Japanese and Hakujin owned sawmills is about 1,000.

Next, I would like to talk about commerce. As I mentioned earlier, in Japan town, there are approx. 100 considerably large businesses. They mainly handle Japanese goods. Some handle silk materials, some even have opened stores in the white districts and are doing well of late. There are also some 250 merchants who run small "confectionery" stores. Almost half of stores that sell fruits etc. in Vancouver are run by the Japanese. In this respect, there is even talk in the City Council of reducing the number of licenses and we don't know how it will turn out. Also there are about 200 engaged in "dry cleaning", "ryokans", restaurants and other miscellaneous businesses. 
According to census taken in 1913, the number of compatriots living in Canada is approx. 12,000. And according to the census of 1939, the number was approx. 23,000 of which 13,000 were Niseis.

Next, I would like to talk about Nisei education. Under the compulsory education in Canada, all children between 6 and 15 must attend school. Children all receive their education in English.

After the English school session ends, Nisei children receive Japanese language lessons for 1 or 2 hours in schools set up by their parents in different districts. In 1921, there were 5 such schools with 500 pupils. Today, there are 49 such schools with student population of some 4.5 to 4.6 thousand. In all of the schools, readers approved by the Ministry of Education are used. There are some 100 who are studying at the provincial university. There are many others who are studying in Japan under their own, and some under the sponsorship of Overseas Education Society (Kaigai Kyoiku Kyokai).

I have briefly outlined the conditions in Canada. For any further details, I would be pleased if you would reference the booklet I have provided.

Next, I would like to avail myself of your kind offer. It is with regard to the current Consul in Canada, as the Consul frequently changes.

At this juncture, Mr. Ban (moderator) intervenes.

Mr. Ban - "Mr. Kagetsu, there is a time slot later on for submitting a wish list to the government authorities. Please make your request at that time."

Mr. Kagetsu - "In that case, I will end my talk."

Next speaker was Koichi Iida of Hawaii who presented his views on how best to inform Niseis about Japan. To this, Kagetsu replied as follows:

In Canada, we have the same situation. In Canada, discrimination against the Japanese is stronger. Even I was watched closely when coming here. As our committee (Kanada Nihonjinkai) on current affairs are engaged in various projects, the president of Nihonjinkai is watched closely at all times. The authorities think he (the president) is the ringleader. I felt embarrassed and was worried at one time if I would ever be allowed back into Canada. I asked the Consul for his advice. That is why I came here with a special "exemption" from the government.

We are well aware of the wartime conditions, and if we are to announce them in the papers, we will be arrested. Such things will not occur in the United 
States. In Canada, when anyone returns to Japan, he can carry with him only $\$ 25$ to $\$ 50$. This amount is only spending money on board the boat. As reason for travelling to Japan, if you say for medical reasons, the authorities would reply back that there are doctors here. If you say for educational reasons, they would reply that Canada has schools also. Somehow or another, we are allowed to go to Japan, but we cannot carry money back. Only $\$ 25$ to $\$ 50$. This is too harsh. As for comfort bags (imonbukuro), there are about 5,000 waiting to be sent. In the bag are letters that are written to cheer up the Japanese soldiers. The authorities say that we should not send such letters to soldiers of foreign countries. Even private letters, if authorities are not notified in advance, you will be arrested. You could be arrested even for the slightest mistake.

Reference: Minutes of the First Conference of Representatives of Overseas Japanese, Tokyo 1940. Co-sponsored by the Ministries of Foreign Affairs and Overseas Affairs 


\section{Aprestoxiv \\ Security Report on Eikichi Kagetsu}

In Appendix 10 of British Security Coordination's Report, there are 35 names in Class A of which the first 16 names included the most prominent men in the Japanese community. My father's name was second on the list and the report on him was as follows:

Eikichi KAGETSU is a wealthy Japanese who has been engaged in the lumber business. He resides at 2867 W. 37 th St., Vancouver, B.C. He is a naturalized Canadian.

Mr. Kagetsu was President of the Canadian Japanese Association for four or five years previous to 1941. The Canadian Japanese Association which is noted for its pro-Japanese outlook has a large membership. During his term as President, this Association was engaged in propaganda work among the Japanese in Canada. On October 1, 1937, the Canadian Japanese Association distributed thousands of pamphlets called "Sino-Japanese Conflict Elucidated", and in 1938 another propaganda pamphlet called the "China Incident". These pamphlets were printed in Japan and were nothing but Japanese Government propaganda on the war with China. Copies of the Tokyo Gazette giving Japan's viewpoint on the China Incident were also kept at the Canadian Japanese Association. While Mr. Kagetsu was President, the Canadian Japanese Association collected money and sent it to Japan to aid in fighting China.

The Publisher of the Canada Daily News, a Japanese newspaper in Vancouver, Mr. Juzo Suzuki, who was interned at the outbreak of the war, owes 
Mr. Kagetsu the sum of $\$ 2,000.00$. In 1939, there was trouble between the Continental Daily News and the Canada Daily News, two Japanese newspapers in Vancouver. The Japanese Foreign Office ordered the Japanese Consul, Nemichi, in Vancouver, to amalgamate these two papers but he was not able to effect a settlement of the dispute. Mr. Kagetsu was called in to iron out the difficulties and was able to bring about some kind of settlement. Immediately afterwards, Mr. Kagetsu took the President and Chief Editor of the Canada Daily News, Mr. Juzo Suzuki, now interned, on a trip to Manchuria and Japan and paid the expenses.

Mr. Kagetsu was invited to Japan by the Japanese Government to take part in the 260oth Anniversary celebrations in 1940 and received a medal or token of merit at that time.

Before the war, he talked along the line that the China Incident was a Holy War, and that the Japanese in Canada must assist Japan by contributing money and by sending comfort bags to the Japanese soldiers. He said that Britain and the United States forced Japan to join the Axis, because they were assisting China, boycotted Japan and terminated the Commercial Treaty.

On a Sunday night about two weeks before the outbreak of war with Japan, Mr. Kagetsu called a meeting which was attended by seventy Japanese. This meeting was held in the Buddhist Temple, Vancouver. Mr. Kagetsu began by saying that in the event of war he was likely to be the first to be interned. He then told each of the seventy men what part they were to play in a crisis.

Mr. Kagetsu has a son, Hajime, attending the University of British Columbia in Vancouver. He was spokesman for the Japanese students attending the University and voiced their objections when debarred from military training in the C.O.T.C.

It has been reported that when the Premier of Japan was in British Columbia a few years ago, Mr. Kagetsu was his chief aide. When he walks down the street in the Japanese district, the Japanese bow to him, the report being that he is considered a Baron.

Many of the Japanese are indebted to him. He represented the Mitsui interests in Vancouver for a number of years.

Mr. Kagetsu was closely associated with Dr. Chikao (George) Hori, a medical doctor with numerous American degrees, who has been interned. It interesting to note that several Japanese subjects in close touch with Kagetsu have been interned while he himself is at liberty, apparently on the sole ground that he happens to be naturalized.

Another internee who owes Mr. Kagetsu money is Kotaro Nakagawa, a drug store clerk, 301 Powell St., Vancouver, BC. 
The Buddhist Temple in Vancouver owes Mr. Kagetsu \$5,000.00. This seems very suspicious in view of the fact that Mr. Kagetsu is a Christian, and also that Buddhist Temples are noted for their loyalty to Japan. The loan would seem to have been made on national rather than religious grounds.

Reference: British Security Coordination. (1942). Report on Japanese activities in British Columbia. (n.p.). 
APPENDIX V

\section{MacInnis Speech on Eikichi Kagetsu Case}

Delivered in Parliament on June 16, 1954

\section{Mr. MacInnis:}

What I am going to speak about, Mr. Chairman, is what I consider a great miscarriage of justice. I refer to the properties which were confiscated-I use that term but perhaps it is not the correct one-from persons of Japanese origin who were removed from the Pacific coast. I discuss it now for several reasons. I wrote several letters to the predecessor of the present Secretary of State without receiving much satisfaction in the matter. Earlier this session, with one of the property owners concerned and his legal representative, I had a talk about the matter with the minister. The proposals for a review of the case were turned down by the Secretary of State. He informed me to that effect, and I told him I did not agree. He was good enough to say that I could speak about it when the estimates of his department were before the house; that is one reason why I am taking this opportunity.

I am speaking about it for another reason. I am not a university man, but I was at a special convocation of the University of British Columbia about two years ago, and amongst those present was the Prime Minister who received an honorary degree. The gentleman who made the address at that convocation was Sir John Morris. I think he is a judge of the appeal court in the United Kingdom. There were two sentences in his address which I noted at the time, and which have stuck with me since. He said: Surely there are few more satis- 
fying experiences than to help set right an injustice. Injustice should be righted wherever, whenever and however it appears.

There are few people in Canada who would deny that there was an injustice done to these people. Not only was there the injustice of uprooting them from their homes and sending them all over the dominion but there was the injustice of a studied attempt to despoil them of their property.

As I said, no matter how long it is since that happened, I agree with Sir John Morris that injustice should be righted wherever, whenever and however it appears. And there is still another reason why I refer to this. When the event of the removal of these people from the Pacific coast took place we were at war with Japan. There is no denying that Japan was a treacherous and ruthless enemy, and that our people who were unfortunate enough to be taken prisoner or to be caught by the Japanese suffered keenly.

However we have made our peace with Japan. We have signed a peace treaty with her. We have made a soft peace with Japan. And I think that having made a soft peace with Japan we should be big enough and generous enough to make a soft peace with those of Japanese origin in this country, who committed no crime, who committed no treachery, and whose only fault was that they happened at a particular time to be in a particular place, and were of a particular racial origin.

That is my reason for taking up the time of the committee in referring to this matter tonight. The case I am going to refer to was probably the largest property involved in the evacuation. I am not taking up this case because it was the largest; there were hundreds of small properties where the lifework of whole families was lost. That is true of the individual about whom I now speak. He was a naturalized Canadian citizen, naturalized as long ago as 1909. The properties concerned were, among other things, two fairly extensive timber limits on Vancouver Island. Like the other evacuees, he was given 48 hours notice to leave his property, to get ready and to be transported to some other place in Canada, in this instance the city of Toronto, where he finally landed.

He was not allowed to go back, of course, to look after his property. Yet he was held responsible for everything in connection with it. He was fined because he had not burned the slash, that is the debris left after felling of timber. He had to pay taxes on the property while it was going to ruin, with nobody looking after it. And in that case he was no different from the others.

\section{Mr Fulton:}

Where was this? 


\section{Mr. MacInnis:}

On Vancouver Island. The firm was known as the Deep Bay Logging Company, and the chief shareholder and manager of the property was a person named Eikichi Kagetsu. One piece of property was known as Block 195 in the Cowichan Lake district on Vancouver island, which he claimed had a market value of $\$ 247,500$. May I say that Mr. Justice Bird was appointed commissioner to set a value on these properties, and to adjudicate upon their value in 1948, six years after the people were removed. This man was then allowed to go back and prepare the records for his property, but he was given only a very short time to do this and most of the records had been lost. While the value he placed upon it was $\$ 247,500$ it was sold by the custodian for the sum of $\$ 93,000$.

The other property was another piece of timberland including 11 blocks of land with a certain amount of felled and cold decked timber, and a stand of immature timber, with some mature timber as well. Mr. Kagetsu put a value upon it of $\$ 292,039$, and the custodian sold it for $\$ 40,000$.

I mention this because I am going to show later on the value that was put on some other assets, and it will give hon. members an idea whether a proper price was received by the owners for this property in the sale. It was sold by tender in 1943, 1 believe, and the attempt at final price settlement was not made until 1948.

Mr. Justice Bird in setting the value took into consideration the amount of timber that was supposed to be on the land; but it is interesting to note that 70 per cent more timber has been cut on the Cowichan Lake property, block 195, than the commissioner said was there in the first place. And they were still cutting a couple of years ago.

In the other case 100 per cent more timber was taken off the property than the commissioner said was on it, and they were still cutting on that property in 1951. And then again there was the immature timber which, if left in this man's possession, would have increased in value as the years went by. There were buildings on the property used as bunkhouses for the men working in the lumber camp. The buildings consisted of 20 family residences, 10 bunkhouses, a community hall, a new office and eight other buildings. These were camps. They were insured for $\$ 10,000$. The commissioner put a value of $\$ 1,000$ on these buildings. He said the reason that he put that value on them was that the buildings-bunkhouses for the lumber workers to sleep in, and the Kagetsu employees were persons of Japanese origin. The commissioner said that they would not be of any value to an Occidental buying the property because the bunks would not be long enough for Occidental loggers. It seems to me that that is an amazing way of putting a value on property that you are 
expropriating or that you are confiscating. Perhaps "confiscating" is not the correct word. It should be the value of the property to the owner, not what it would bring at a forced sale; it should be the value to the man who owned it and controlled it.

Then again there were some railways on the timber limit. There were $81 / 2$ miles of logging railway, if I remember correctly. Anyone who knows anything about building railways in British Columbia, through the terrain there, knows that it costs money. Not all of this line had rails laid on it, but what did not have rails laid on it had been graded so that a truck could drive over it. For this railway the commissioner allowed the sum of $\$ 1,000$. If I remember correctly, the reason he gave for that was that the person who was buying the railway would not be using it. That again is an unusual way to put a value on something you are taking from someone and selling at a forced sale. Surely the criterion is the value to the man who owned it, the value it was really to him if he were allowed to use it in his own way for making a living.

No allowance was made for the forcible removal from the property. If that was done to any member of this house what would he think? What would you think of that as justice? You may say it was all done legally; that orders in council were passed and so on. Surely, meeting legal requirements is not meeting the ends of justice. I have before me a statement made by a very well-known gentleman in this country who spoke to the Quebec bar association on January 5, 1953. He said this:

"Thus when you are studying present administration of justice or new methods of procedure you are helping your country to preserve, not only justice but all the fundamental liberties that we have fought for, won and defend as essential to our way of life."

I suppose every hon. member would agree with that. Who said it? No less a person than the Prime Minister of Canada. It is said that the Minister of Justice was at the same meeting and also the solicitor general of the province of Quebec. I agree with the words of the Prime Minister. If what he said is true, then it is high time we reviewed the action we took in providing compensation for the property of people who were forcibly removed from the province of British Columbia and, let me say again, people who had committed no crime and who were never accused of any crime. I agree that it is a long time ago, but if we are going to take the words of Sir John Morris that I read before:

"Surely there are few more satisfying experiences than to help set right an injustice. Injustice should be righted wherever, whenever and however it appears-

- here is an injustice that, in my opinion, should be righted. In one of the letters I had from the former secretary of state he said that this property, the 
Kagetsu property had not been profitable in the years prior to the evacuation; that is, in 1939, 1940, 1941 and 1942. That was true of a great many properties at that time. But lumbering was a very lucrative business in British Columbia from 1942 at least until quite recently. But again I say that that should not be considered in making a just award for this property. I have before me the report of an arbitration award in the matter of the Beauharnois shareholders in respect of property taken over by the government of the province of Quebec. This statement appeared in the Montreal Gazette of March 21, 1953. The arbitrators had this to say:

We think it is pertinent also to refer to the fact that the Beauharnois undertaking was in 1944 emerging from its lean year-

Let us say that the Kagetsu business in 1942 was emerging from the lean years. I continue:

-a process experienced by nearly every industrial undertaking. It takes time to build up a well-trained operating staff, to iron out operational problems and difficulties.

It is only after such things are done that the profits begin to come in and, as I said before, the same principle would apply in regard to the Kagetsu property. I would urge the Secretary of State, in taking over his new office, to think of the high regard in which the matter of dispensing justice is held in this country. I hope that we do not only give lip service to justice when making speeches before bar associations or at university convocations, but that it is something we believe in every day of the week.

The minister is a new man, new in his office and new in the government, but there are people in Canada and I am sure people in the present government who I am quite satisfied agree that perhaps next to the expulsion of the Acadians this is the darkest stain on the escutcheon of Canada. I say this committee should give its approval to having someone review this entire matter. The review which was made by the commissioner who made the award in the first place is an altogether amazing way to appeal a case. I would like very much to have this case referred to the exchequer court, where such cases should be referred, and have this matter reviewed by the present president of that court. I would be most interested in what he would have to say. 


\section{Mr. Philpott:}

Is the hon. member suggesting that the procedure in this one particular case where the amount covered is $\$ 93,000$ should be subjected to review, or does he mean all cases?

\section{Mr. MacInnis:}

I would suggest that in all these cases where there has been an injustice there should be a review. I mention this case because I was consulted in connection with it, and first approached by a solicitor in Vancouver, then by Mr. Kagetsu, and I said-

\section{Mr. Philpott:}

Did this man appeal his case to the court of appeal or a royal commission?

\section{Mr. MacInnis:}

There was only one appeal in this case as far as I understand, though the Secretary of State may correct me if I am wrong. It was reviewed by the commissioner who set the value on the property in the first place, Mr. Justice Bird of the appeal court of British Columbia, and an appeal was later made to him for revision. He heard the case and made a small adjustment amounting to some $\$ 2,000$ odd. But in my opinion the appeal should have been sent to some justice outside the province of British Columbia, and the proper court to which appeals should be referred is, in my opinion, the Exchequer Court of Canada.

\section{Mr. Herridge:}

Mr. Chairman, I want wholeheartedly to support the plea addressed to the Secretary of State by the hon. member.

Reference: MacInnis speech. Canada. Parliament. House of Commons. Debates. (Hansard). 22nd Parliament, 1st session. Official Reports. Vol. VI, 1953-54 (June 16, 1954), p. 6094-6098. 
APPENDIX V I

\section{Eikichi Kagetsu Descendancy Chart}

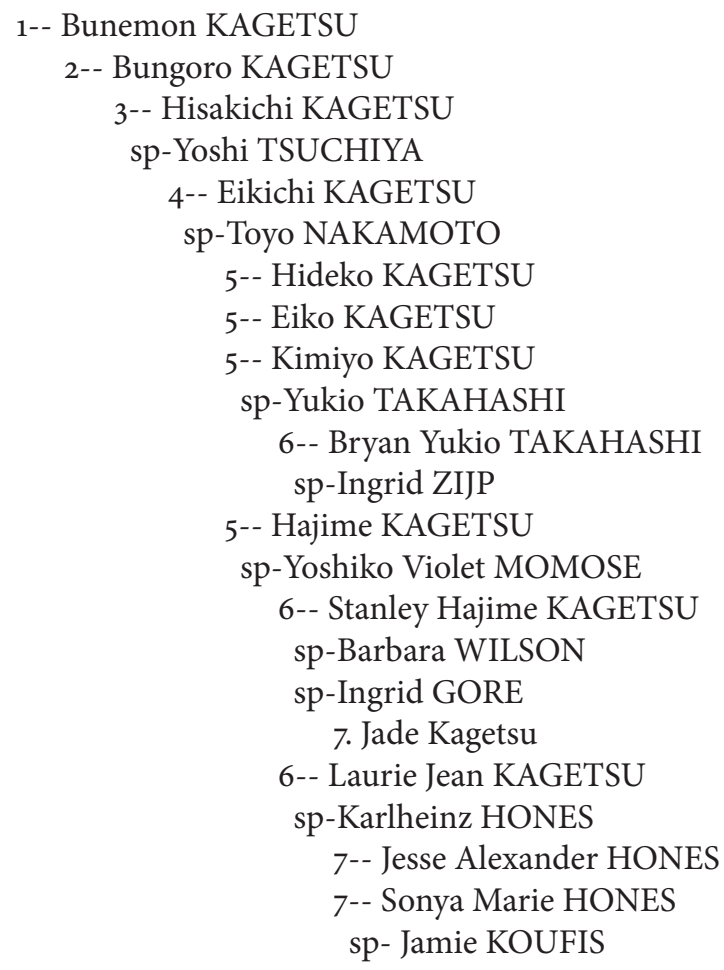




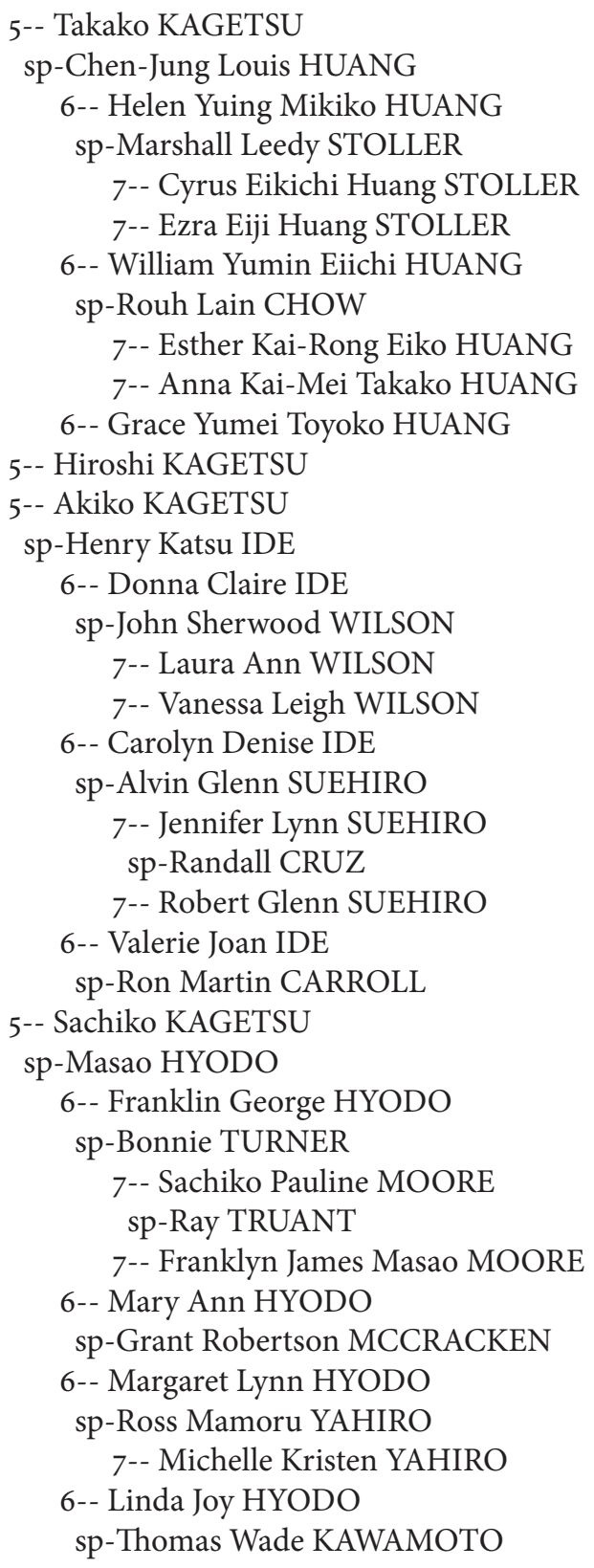


7-- Stephanie Takara KAWAMOTO

7-- Matthew Thomas Masao KAWAMOTO

7-- Ellen Sachiko KAWAMOTO

7-- Jessica Chieko KAWAMOTO

5-- Akira KAGETSU

sp-Elsie Matsumi SAITO

6-- Diana Keiko KAGETSU

sp-Douglas Blackburn Keogh MARTIN (divorced)

7-- Mindy Heather MARTIN

sp-Stephen NICHOLSON (divorced)

8-- Kamea Phoenix NICHOLSON

sp-Darren CRYSTAL

7-- Amanda Rose MARTIN

sp-Tom John MORGAN

7-- Gordon MORGAN

6-- Timothy Leslie KAGETSU

6-- Catherine Michiko KAGETSU

6-- Nelson Samuel KAGETSU

sp-Luisa CURTIS

7-- Alisha KAGETSU

5-- Tadashi Jack KAGETSU

sp-Kanaye Kay TSUCHIDA

6-- Nolan Jack KAGETSU

sp-Nivin PEI

7-- Kristin Pei KAGETSU

7-- Lauren Pei KAGETSU

6-- Naomi Jayne KAGETSU

sp-Timothy BUKOWSKI

7-- Christopher Michael BUKOWSKI

7-- Anna Kanaye BUKOWSKI

7-- William Kagetsu BUKOWSKI

7-- Timothy John BUKOWSKI 



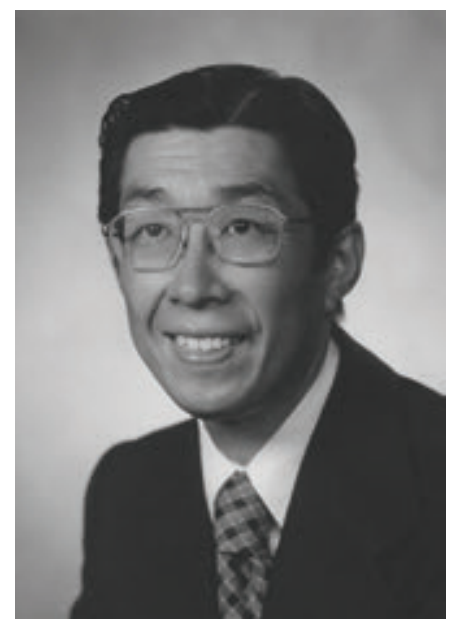

Author Tadashi Jack Kagetsu (1931-2006) was the youngest son of the "outstanding Japanese Canadian" and prominent Nikkei timber industrialist Eikichi Kagetsu. In The Tree Trunk Can Be My Pillow, Jack details the fascinating life and accomplishments of his father, and he follows the Kagetsu family across oceans and continents, telling a uniquely Japanese Canadian story of economic success and sudden dispossession. Jack Kagetsu was a highly talented individual. He received his $\mathrm{PhD}$ in Chemical Engineering from the University of Toronto in 1957. He went on to an accomplished career in the United States with the Union Carbide Corporation, where he received two patents for technical innovation. He was also a chess master-as a university student, he defeated a Russian grandmaster as well as a US and former world champion.

The Tree Trunk Can Be My Pillow is the result of over ten years of research that took Jack across North America, from New York to Virginia, Ontario to British Columbia, on a mission to reconstruct his family history. It is the culmination of Jack's quest to reclaim lost years, lost knowledge, lost geographies, and lost memories. Published over ten years after his death, this book tells the remarkable story of Jack's famous father, and it is an important text for anyone interested in Japanese Canadian history. But the book also represents a personal vindication-a son's repossession of memory, of relationships, and perhaps ultimately of history.

- Trevor Wideman, Simon Fraser University

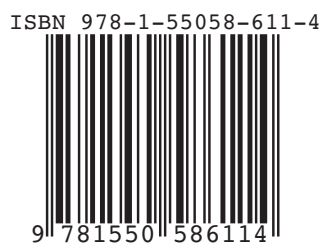

University of Victoria 